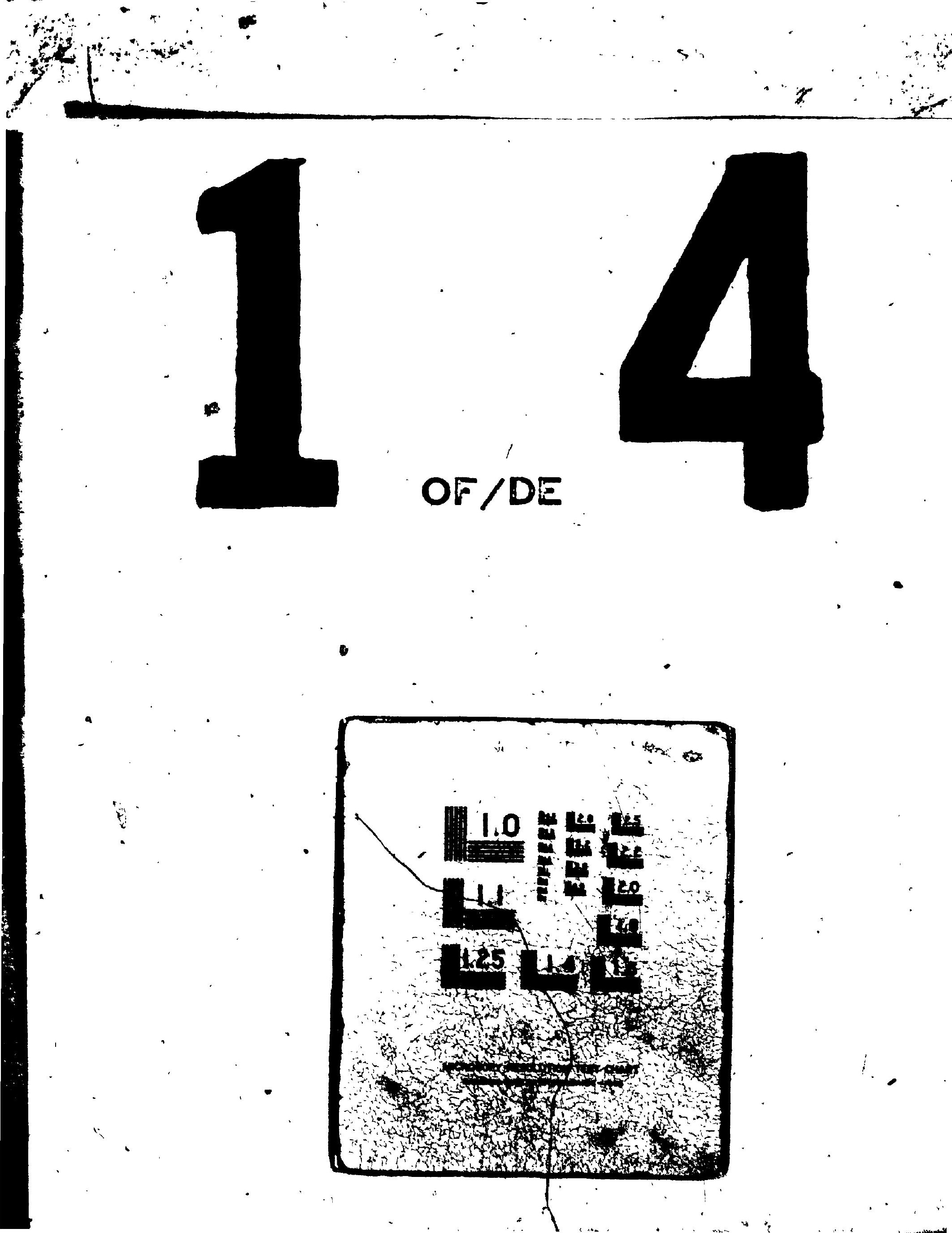


26594

National Library of Canada
Bibliotheque nation ale du Canada
CANADIAN THESES ON MICROFICHE
THESES CANADIENNES sUn mICHOFICHE

NAME OF AUTHOA/NOM DE L'AUTEUR

William E. Dickens TITLE OF THESIS/ TITRE DE LA THESE

A Plan for the Recovery and Long-term Development of Beef Cattle in the Sahel

UNIVEASITY/UNIVEASITE The Norman Paterson School of International Affairs, Carleton $U$.

DEGREE FOR WHICH THESIS WAS PRESENTED/ GRADE POUR LEQUEL COTE THE SSE FUT PIE SENTE

- YEAR THIS DEGREE CONFERRED/ANNEE D'OATENTION OE CE DEGAS_ 1976

NAME OF SUPERIISOR/NOM DU DIRECTEUT DE THE े SE

Professor A.R.M. Ritter

Permission is hereby rented to the NATIONAL LIERARY OF CANADA to microfilm this thesis and to lend or sell copies of the film.

The author reserves other publication rights, and neither the thesis nor extensive extract e from it may be printed or otherwise reproduced without the author's mitten permission.
L'outorisotion est, per le presents, accondise IO BIBLIOTHEQUE NATIONALE DU CANADA do microlilmar cate these ot do prefer au de ventre does exemplaines du film.

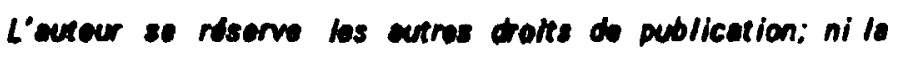

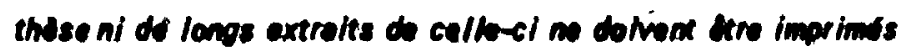
ow cuthmant reproduce sens routarlsation faerie do rector. DATEd/aAn 15 January 1976

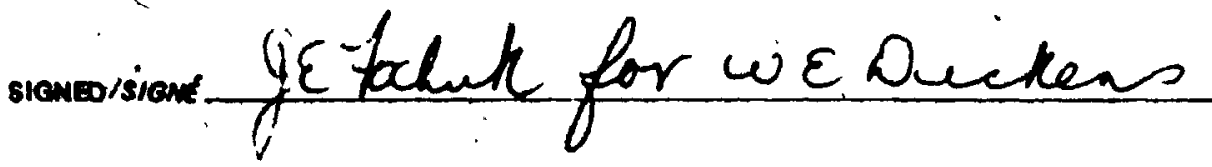
23 Langhoin Crescent, Ottawa, Ontario, K2J IHI 
INFORMATION TO USERS

THIS OISSERTATION HAS BEEN MICROFILMED EXACTLY AS RECEIVED

This copy was produced from a microfiche copy of the original document. The quality of the copy is heavily dependent upon the quality of the original thes is submitted for microfilming. Every effort has been made to ensure the highest quality of reproduction possible.

PLEASE NOTE: Some pages may have indistinct print. Filmed as received.
AVIS AUX USAGERS

\author{
LA THESE A ETE MICROFILMEE \\ TELLE QUE NOUS L'AVONS RECUE
}

Cette copie a ete faite a partir d'une microfiche du document original. La qualite de la copie dépend grandement de la qualité de la these soumise pour le microfimage. Nous avons tout fait pour assurer une qualite superfeure de reproduction.

NOTA BENE: La qualite d'impression de certaines pages peut laisser a desirer. Microfilmée telle que nous I'avons reçue.
Canadian Theses Division Cataloguing Branch National Library of Canada Ottara, Canada KIA ON4 


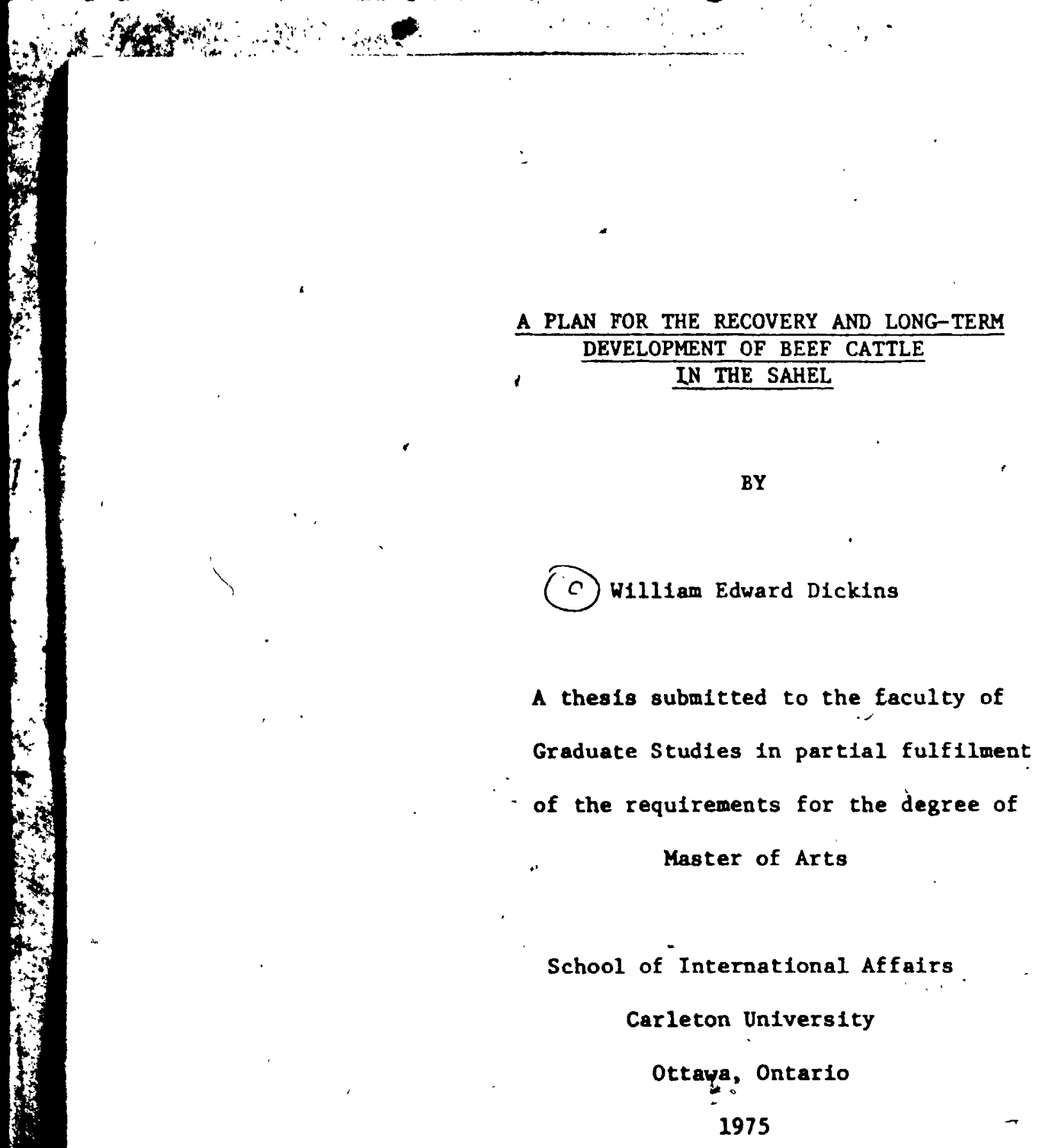

A PLAN FOR THE RECOVERY AND LONG-TERM IN THE SAHEL

BY 
$\therefore \quad 40 x+2$

The undorsigned hereby recenend to the Faculty of eradunte Studies and meareh acesptance of this thesis, subultwed by Willea Edward Dickims, In partial fulfilmant of the requirements for the cegres of mitar of Arts.

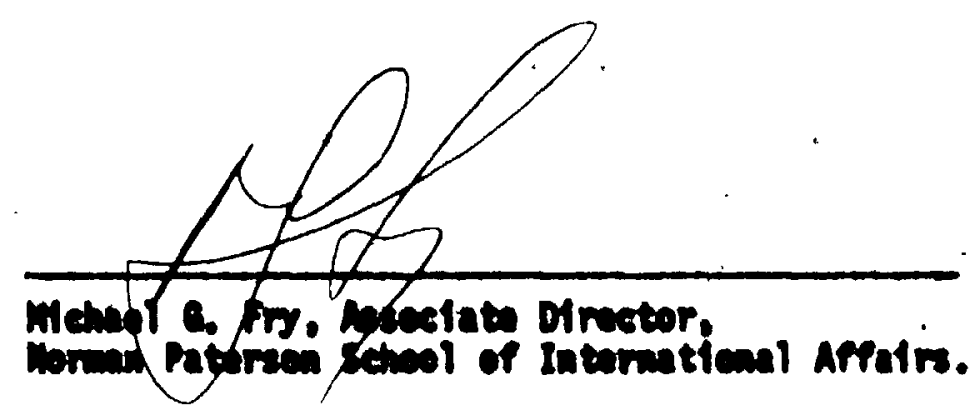

Q. R.M. Zitter

Anon. After, Emarvisor. 

and ond

\section{INDEX OF TABLES}

TABLE No.

TABLE TITLE

PAGE Na.

2-1 Livestock Production in 1972.

33

2-2 Selected exports of processed meat and

35 I1ves enimals from the Sahel.

3-1 Land utilization and population densities

44 of the Sahel countries.

3-2 Population est1mates, annual rate of 1ncrease 46 and population projections.

3-3 Deb1t des grands fleuves du Sahel. 49

3-4 Gross National Product per capita (1972) for 56 the developing nations of the World.

3-5 Gross Domest1c Product, per capita GDP, annual growth rate of per capita GDP and population.

3-6 Structural components of Gross Domest1c Product. 59

3-7 Agricultural population 1970 . 60

3-8 Comparison of the average annual growth rates 62 between food and agriculture.

3-9 Total value, balance and growth of exports , 64 and Imports for the Sahel 196901971

3-10 Share of 11vestock exports in GDP and cotal exports.

3-11 Share af food imports in total imports.

3-12 Net flow of loath and grants to the Sahel 70 countries.

541 Benf and veal: Production; consumption, and trade balances for 1970 and 1980 profections.

5-2, Worid 1mports of live cettle and proceseed 
5-3 Cattle production of live animals. 104

6-1 Average water consumption during the dry 124 season.

6-2 Numbers enrolled in, and growth rate of, 141 the educational institutions.

8-1 Estimated cost of fence construction. 206

8-2 Estimated stock numbers. $\quad 207$

8-3 Data for well requirements. 210

8-4 Start-up herd: Compostion and cost estimate. 213

8-5 Betlmated annual payroll and staff requirements. 228

9-1 Noandic familles in each Ranch operation 238 annually.

9-2 Bstimated Real Property: Cap1tal requirements. 243

9-3 Capital investment required. $\quad 244$

9-4 Est1mated annual operating costs. 245

9-5 Batfmated annual revenue from 11vestock sales. 247

9-6 Profit and 1088 summary. 248

11-1 Botimated annual costs of the Reglonal Range 271 Mnagement Organisation. 


\section{INDEX OF MAPS}

Map No."

1.

2.

3.

4.

5.

6.
MAP TITLE

The countries which form the Sahel.

The maln climatic zones based on rainfall distribution as delineated by isohyets.

Percentage of normal for the 1973 ralnfall.

The main cattle ralsing area of the Sahel countries.

Australian Research Station.

Ideal Ranch lay-out.
Page No.

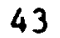

48

52

54

204

\section{INDEX OF CHARTS AND DIAGRAMS}

Chart Xe.

$3-1$

$5-1$
TITLES

Lac Chas: Variation Interannuelle du niveau $\mathbf{a}=\mathrm{Bol}$.

The relationship between income and meat consumption: selected countries.
Page No.

50

100

D1agram No.

\section{8-1}

10-1

11-1

11-2
Bconomic Iinkages.

Developeant needs of sector integration. Organisation for Range Management of the Sahel countries.

National office Organisation. 
$=x+4$

\section{ABBREVIATIONS}

A.I.D. Agency for International Development

A.S.E.C.N.A. Agence pour la Sécurtté de la Navigation Aérienne en Afrique

C.C.T.A. Comission of Technical Co-operation in Africa

C.I.D.A. Canadian International Development Agency

ECOSOC United Nations Economic and Social Council

F.A.0: $\quad$ Food and Agriculture Organisation

G.A.T.T. General Agreement on Trades and Tariffs

G.D.P. Gross Domest1c Product

G.N.P. Gross National Product

I.A.R.S.S. Institute for Agricultural Research and Special Services

I.B.E.D. Inter-African Bureau of Eplzootic Disease

I.B.R.D. International Bank for Reconstruction and Development

I.C.A.0. International Civil Aviation Organisation

I.E.M.V.T. Blevage et de Medecine Vêterinaire

I.F.A.N. Inst1tut Fondemental D'Afrique Nolre

I.L.0. International Labour Organisation

I.L.R.A.D. International Laboratory for Research on Animal

D1seases

I.R.A.T. Institut de Recherches Agrononiques Tropicales

O.R.S.T.O.K. Offsce de Ia Recherche Sclent1fique et. Technique Outratier 


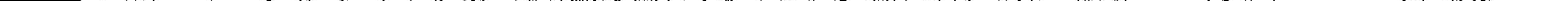



Magy Plans can, and have been produced, dealing with one or more aspects of economic development. However, unless they have been clearly prepared with strong consideration being : given to the management of the Plan's implementation, they have become fust more 'dust collectors' in a library. Hence, the first point of consideration must be that the Plan must not be overloaded with theory, because theory per se, cannot be managed. In this regard, therefore, the Plan must be kept simple without reducing the quality of the final objectives. A less sophisticated Plan should make it easfer to establish objectives for each of the stages of implementation, thereby simplifying the management of the Plan's implementation.

The above paragraph referred to the establishment of objectives for each phase of plan implementation and the management of the plan to obtain these obfectives. Hence, this system of Plan Development may be sald to be using the concept of 'Management by Objectives' since that is the method needed for implementation.

Within this conceptual framework, the author, has examined the problems of the Sahel as they pertain to the development of a beef cattle Industry economy in the region. After which, the appropriate objectives for beef developwent have been estabifity In a PIan (chapter VIII) as well as some criterla for measurement and Implementation (chapter IX). 


\section{A SUMMARY OF THE PLAN}

The Plan presents system of Ranches to be established throughout the entire Sahel region. Th1s $1 \mathrm{~s}$ based on the premise that a Mul1-national Beef Development Strategy is paramount. This premise is not unreasonable since presently the nomadic herdsmen do not respect any national frontiers. While the Ranch approach is not new, a Muli-national Ranch Strategy leading to a self-sustaining beef Industry whin 15 to 20 years is believed to be a fresh idea.

Specifically, this Plan would establish Ranches at a minimal cost, at least when compared to the cost of other aid profects, and at the same time it would seek to have the Ranches run, almost totally, by the indigenous people within five years. By the twentieth year, it is concelvable that the system of Ranches could be owned by the ex-nomadic herdsmen on a co-operative basis.

\section{These Ranches are not belng proposed as small scale} examples of what can be accomplished in the arid and semi-arid reglons of the Sahel, as has sometimes been the case with smaller Ranchea. They would be, Instead, large profitable Ranch complexes encompasing a full range of operations from breeding, range managewent, forage and fodder production, slaughter and marketing. Each Ranch, being of approxinately 400,000 hectares, is planned to 
.

eventually provlde a livelihood for 42,000 people $(7,000$ nomadic familfes). Thus, the initial Ranch system of $81 x$ locations will provide a livelihood for about 250,000 nomads directly, and many more indirectly.

$\dot{0}$ Though 250,000 may not seem many when compared to the total nomadic population of the Sahel which has been variously reported from 2 to 6 million, a 'concrete' base for 250,000 and a potential for growth because of a solid foundation 18 , in the view of the author, more useful than a Plan to employ 1 million nomads, but bu1lt on 'sand'.

Ostensibly, developing a Plan to assist the recovery and development of a particular industry within a developing économy would seem to be a straightforward case of modernisation. However, wh1le 'modernisation' implies technological change, the knowledge of the people involved must 11kewlse be up-dated. It is this process of changing peoples' ideas which then becomes the problem of soctal development. Obviously, therefore, without social development, technical modernisation must be doomed to fallure.

Y The Plan presented herein, clearly reflects the underlying assumption that social progress, or development, is the key to the future success of the Plan. It 18 recognized that the process 
of changing peoples' tdeas and ways of thinking is a difficult and long-term task. This is particularly hard in the Sahel, since the traditional approaches and value systems have been handed down through the tribes for hundreds of years. These factors of social change will not be listed here, however, they will be sumarised in chapter XI of this thesis. Suffice to suggest that through education and work the nomads will eventually own the Ranches on a co-operative basis, although, the idea of co-operative ownership may take a number of years. Hence, the concept of social change in this Plan is accepted as being the slow road to modernisation, as opposed to the fast road to disaster. Furthermore, it may well be that the initial group of nomadic Ranch workers never do completely adopt the concept of a more modernised beef industry. After all, traditional ideas and values die hard. Thus, the success of the Plan of this paper more truly lies in the ability to educate and up-date the ideas and attitudes of the second and third generations, namely, those born in the Ranch environment.

\section{THE TRESIS ORGANISATION}

The thesis organisation is really cleafly sub-divided into three sections. Part I, containing chapters II to VI Inclusive, is concerned with defining the countries, problems and the 
evolution of the problems. Part II, consisting solely of chapter VII, may be viewed as, a bond between Parts I and III. In 11ght : of the problems and barriers to beef cattle development shown in Part I, chapter VII summaries sowe of the research undertaken elsewhere which could aid the Sahel. Part III, being chapters VIII to XII, deals with the Plan and the practical implementation of that Plan in the real environment of the Sahel.

a. Part I: Chapter II, provides a brief summary of the historical and social aspects of the development of nomadisa, with particular reference to the Sahel, after which, chapter III bring nowadism fnto focus by detailing the geographic location and the economic background of the six countries

- whlch form the Sahel region. Certaln problems are highlighted where they are of historic origin such as climate, population division, the economic situation with reference to World trade, domestlc agriculture, manufacturing, and skilled personnel, or the lack thereof. This chapter endeavours to provide a complete picture of the Sahel area as it existed prior to the recent major drought. To this end, pre-drought statistics have been used (also belng the only ones avallable).

With chapter III being concerned with the pre-drought econonic situntion, chapter IV sets out to explain, In somé detall, the causes of the recent economic plight in the Sahel. 


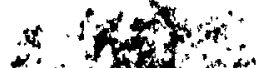

Here 1t 18 more fmportant to note that the causes of the recent drought-crisis are not solely climatic, but that the the odtstrophe is partly rooted in poor agricultural development policles. Further, this chapter shows some Information about the World's response to the drought disaster which struck the region.

After this total view of the Sahel economies, chapter V examines the situation of livestock in World trade with particular emphasis on the problems of the beef industry, past, present and future. Then there follows a description of the Importance of beef cattle in the Sahel countries, thereby clarifying why a beef Industry development plan is a worthwhle aim for both the Sahel and this thesis.

In the premise that these early chapters all fccouplished hed r respective objectives, chapter VI then sets about the tadk of examining the fundamental elements which are needed for the successful development of a beef cattle industry. Such elements being/fevieved consisting of the water requirements, disease controh feed and grazing needs, education, manpower, markets and transportation.

b. Part II: This section was mentioned as consisting solely of chapter VII, thus forming a bond between Parts I and III. Th1s chapter is seperate because, it doss not refer to the 


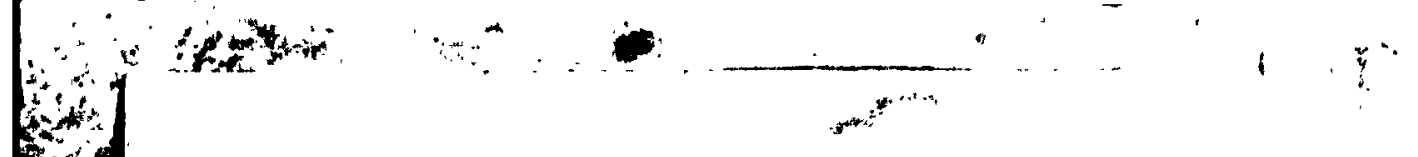

Sahel in a direct manner. Instead, it seeks to summarise some of the research which has been undertaken in other areas of the World which, in the view of the author, could prove helpful to the beef cattle industry of the Sahel.

it is for this chapter that considerable work had to be dqne in order to evaluate the experimentation of the scientific experts; these being geologists, soll sclent1sts, botanists, and blologists to mention but a few. Hence, this chapter is sub-divided Into many parts, commencing with soll evaluation and Information following through fodder crops with other forms of cattle feed, detalls of some cattle breeds, cattle diseases, and concluding with a brief examination of the industry or manufacturing side of beef production, including abattoirs. This chapter w11l show a distinct blas in favour of a vast amount of experimentatiol undertaken in the Northern Territories of Australla. The reason for this bias will be clear when the Australian research is summarlsed. However, here it can be stated that the experiments so documented are selected on the basis of easy adaptability to the Sahel. There 1s a limited amount of documented research in Spanish and Portuguese, pertaining to the Argentine, Uruguay and Brazil. Hovever, while the author must admit to a language problem when dealing with research from South America; it was possible to deternine that this research would not be useful to the Sahel for the following reacons clinatic problews are different; 
nomads do not exist in South America; markets for South

American beef have been developed with the developed nations; South American experimentation related more to the problems which exist for the cattle industry in South America. It 18 also for this last reason that the Canadian and United States research and development on beef cannot be considered as being too useful to the fahel countries: Climate, soll, feeds and cattle types are different.

c. Part III: Following the falrly comprehensive listing of some of the relevant sclentific research, it is then possible to propose a beef cattle development plan using the data of chapter VIII. The Plan attempts to cover all phases of beef development, from Ranch ste selection and layout, through grazing, feed, the herd, the feedlot operation, the abattolr section, transportation modes, disease control, employment of the nowads and the long term possibilities of such a scheme. With the Plan having been proposed in chapter VIII, it behooves the writer to clarify how such a Plan may be implemented, thus; turning a very theoretical schewe into a very practical application. To this end, tables and calculations, though primartly for 1llustrattve purposes, have been produced with as much accuracy as is possible without actually visiting the Sahel. 
$\mathbf{0}$

Needless to say, the development of a substantlal beef cattle Industry in the Sahel could have many Implications for other sectors of the economy. Hence, chapter $X$, tries to explore the se implications as they apply to the agricultural farming sector and the sociological aspects of the nomadic change.

Having presented the.Plan and a method for Implementation In 'neat package', such a proposal in no way guarantees that this concept and approach will be ut1lised. After all, the suggestion was made that all six countries of the Sahel plan and develop anch system along almost Identical lines. This can be sowewhat diffacult unless some form of co-ordinating body Is established. Hence, chapter. XI discusses an Idea for a supra-national organisation which would have the total responsab1lity for Range Management and the related sectors of the economles. therqby being able to co-ordinate the beef cattle development throughout the Sahel.

\section{OTHER STUDIES CONCERNED WITH BEEF CATTLE DEVELOPMENT IN THE SAHEL}

There have only been two other studies made concerning beef cattle development in the Sahel region. Both will be described here since the approaches suggested by these two reports, while not In conflict with this thesis, are sowewhat different. 
$\therefore x^{-4} \quad \cdots$

a. Etude sur la situation actuelle de l'élevage dans les pays du Sahel et des mesures de sauvegarde à envisager. (1974)

Comnission des Communautés Européenes sur le direction du Fonds Européen de, Développement.

Th1s Report was prepared by a flve-man team of experts on matters pertaining to the Sahel, providing the most comprehensive analysis of the region. Their study covers the entire livestock 1ndustry as it existed in all the Sahel countries up to July 1973.

While the team examined the total situation, they did not develop a single Plan for any specific sector of the economies. But, Instead, the Report proposed a Supra-national Committee such as presently exists for Sahellan Drought Rellef (Comfté permanent inter-états de la lutte contre la sécheresse CILSS). The Comittee would be responsible for working with each country in order to provide some rationalisation of resources and development funds.

In addition to the fove proposal, the Rgport examined all the deyelopment schemes, both emergency and long-term, that have been approved for the Sahel countries (123 projects in total). From the total mass of data the Report makes numerous recomendations which should be Incorporated into the Development Plan of each of the countles, thus, ensuring some form of Regiond Co-Operation. These suggestions whit be considered a Forming a total Reglonal Development strategy. 
With the overall strategy being suggested and all the Individual profects being listed, one is presented with a huge 'fig-saw puzzle' since because of the scope of the Report, at no time is the complete picture presented in terms of the final benefits to any individual sector. Rather the Report goes on to point out that experts in each field should now develop the separate sectoral Plans, under the overall strategy suggested, so that the final mosalc can be developed.

On the whole, it is an excellent document which should be serlously considered by the Planners in Ouagadougou, Upper Volca.

b. Ranching/Mixed Agriculture Program in Niger. (1974)

A feasibility study for Africaire prepared by Texas Tech. University, Lubbock, Texas.

This second Report, produced by a team of experts, provided a comprehenstve feastbility study which was concerned with the establishment of a cattle ranching/mixed agriculture enterprise In Niger. The enterprise is proposed as a small scale model designed to demonstrate the merits of employing modern methods for range management, combined with techniques to reclatm drought ravaged areas and restore them to productivity.

It is amall scale only in that only 500 nomadic families will be Involved in the project with annual production of cattle. for slaughter being a wore 4,000 head after five years. While 
$=\because$

\begin{abstract}
the f1gures of 500 families and 4,000 head of cattle might be reasonable if only a small amount of financial ald were needed, In light of the $\$ 23,641$, 0no needed for this demonstration model, at $\$ 47,282$ per famlly the scale would seem hard to justify.

In addition to the two weaknesses of $h 1 g h$ cost and small scale, there 18 a further problem in theuguggestion and that is the need for the nomads to run their own show as soon as possible. The impression from the Report is that external experts would operate the model, but this leaves open the question of, "What about similar schemes?" "Tho will set them up?" "Who w111 run ther?"

Nonetheless, despite the short-coming mentioned above, clearly a lot of data has been collected which can be very useful for any Planners considering cattle development combined wth mixed agriculture.
\end{abstract}

This Thesis, in ro way conflicts with the two studies fust described. The Beef Cattle Development Plan of Part III of this paper clearly fits under the overall Regional strategy proposed In the first study commissioned by the Fonds Européen de Développement. Thus, it way be considered as one of the detalls sectoral studies which the first Report actually recomends. 
$\therefore \alpha^{4}$

With regard to the Texas Tech. study, again the suggestion of this Thesis does not conflict. This Thesis is looking towards an entirely different set of objectives. The Texas Tech study aims at the development of a model for cattle raising in confunction with agriculture. The alm is not so much to provide a major economic contribution to the Sahel, so much as to provide an example of a livelthood for the nomads which can be considered as one means of providing them with self-sufficlency so that they can withstand climatic catastrophe in the future.

1 However, by comparison, this Thesis seeks to make a substantial impact on the economies of the Sahel. A fact to be accomplished by providing a livelthood for over 42,000 families, - who will provide 1,200,000 head of cattle for slaughter annually in later years. All, for an Inftial investment of $\$ 4,157$ for family, although the sum of $\$ 1,857$ would be repald to the ald donor nations, leaving a net investment of only $\$ 2,300$ per family. This latter Investment figure would seem reasonable in 1 ight of the fact that such an investment would, over a twenty-year period develop a selfsustaining beef cattle industry for all six countries of the Sahel. In addition, there would be a number of other economic benefits from such acheme through the basic economic linkage mechanism vich would. develop (see Diagram 8-1 and chapter VIII for discussion of the linkage benef1ts). 


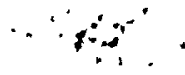

*

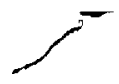

16.:

SUMMARY

In summary, it should he reemphasised that the Plan proposed in this Thesis, while it may not be the final project, most assuredly has a number of points which should be considered by the Development Planners working in the region.

It is alsowrorti reiterating that the Plan is a large scale Ranch system concerned with the entire Sahel as one vast $\therefore$ cattle raising integrated region. However, while the technical aspects of this proposed Beef Cattle Plan present few problems for the implementation, the major problem of 'social change' is really

- the key to success. Hence, the watchword for the Implementation managers should be: PATIEIICE and UNDERSTAIDING.

$\cdot$ 


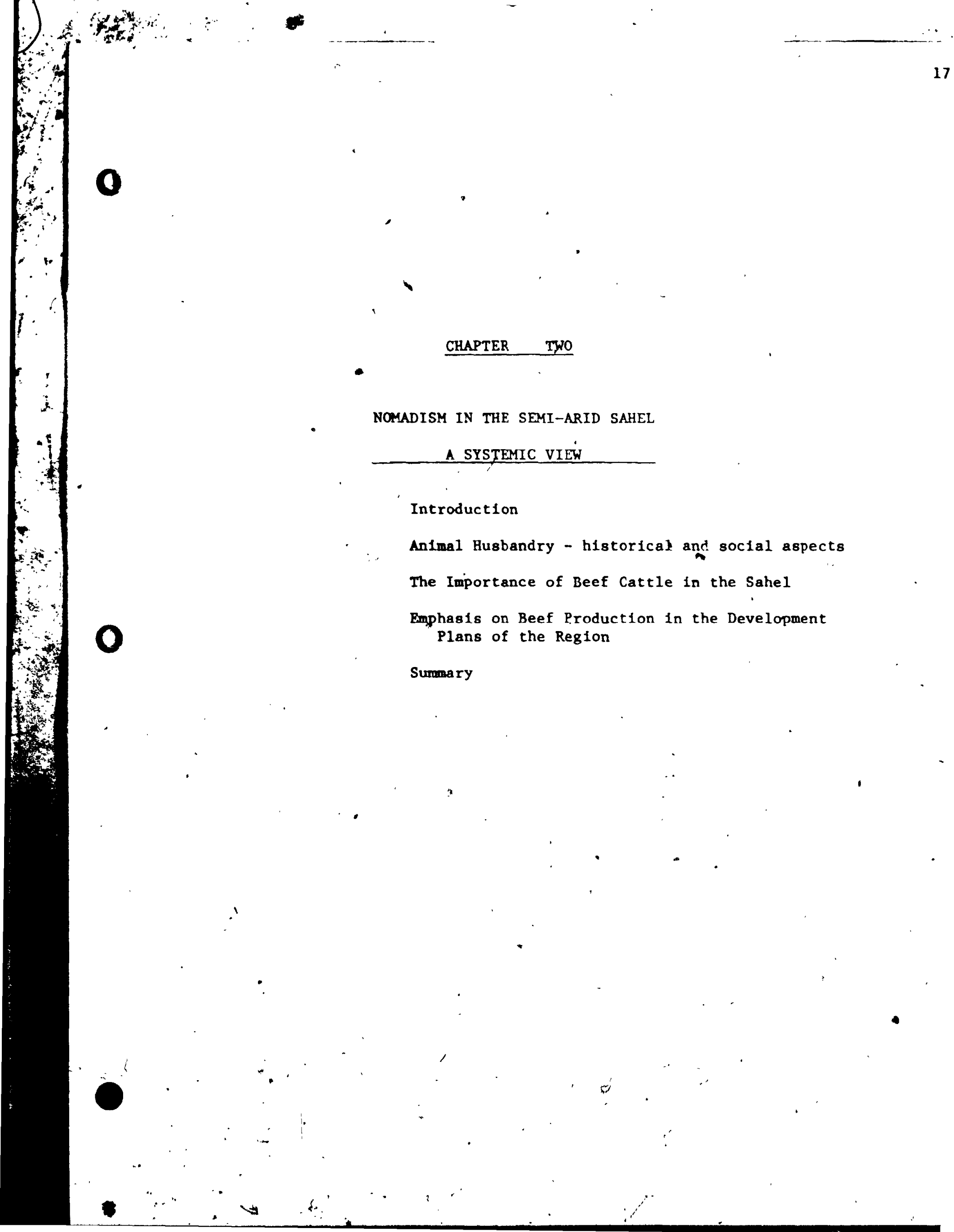




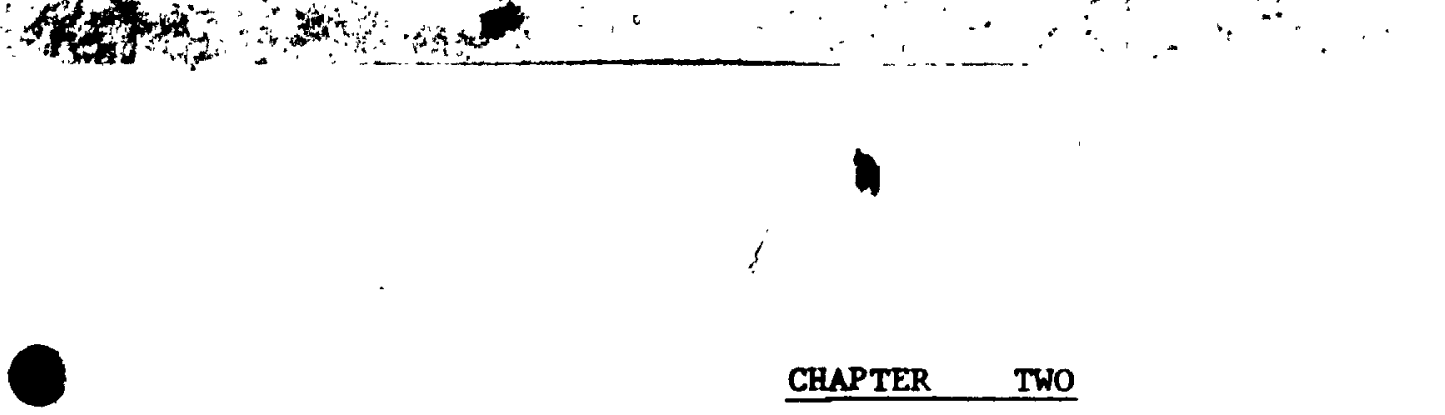

CHAPTER TWO

NOMADISH IN THE SEMI-ARID SAHEL:

A SYSTEMIC VIET

\section{INTRODUCTION}

In this chapter the historical and social aspects of -

nomadism in the Sahel are considered, particularly with reference to the evolution of antmal husbandry and the traditional beef cattle Industry, as it more recently exists in the region.

\section{ANIMAL HUSBANDRY - HISTORICAL AND SOCIAL ASPECTS}

Since the earliest history of man, animals have been domesticated; they represented an important aspect of the economic* structure and also had a significant effect on the social systems. of primitive socleties. Antmal husbandry was, and still remains, the most important form of land use in the semi-arid zones of the "Old World"1. There has, in fact, been little change in its characteristics and management in these regions over the centuries.

While it is acknowledged that there may be many reasons why animal husbandry throughout the old World could, or should be Improved, the concern of this paper is oolely for the Sahel. 2. Bowever, it 1o undoubtedly true that all the aress of the 01d World deserve far more attention in relation to the-1oprovement of 


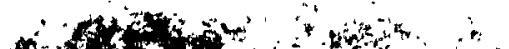

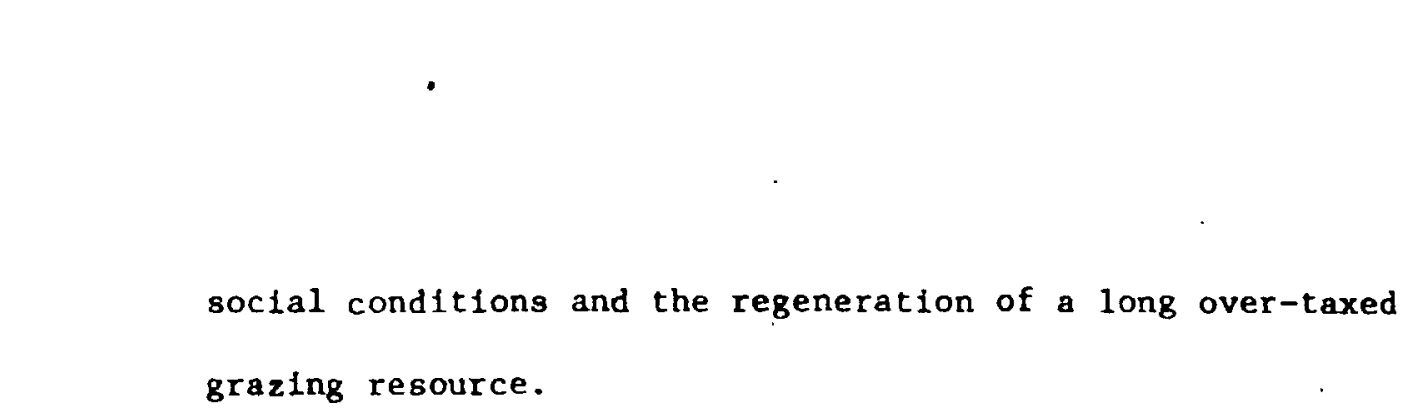

The modern types of animal husbandry are favoured by research and other facilities with comparatively less competition for the existing or potentlal resources. For these reasons, some of the techniques developed in the more advanced countries may, wth appropriate adaptations, be transferred to the less developed zones.

The history of agriculture and land use has not yet been written, but certain fragmentary information may be found In a number of published works. 'Sauer?' reviewed the problems of agricultural origins and dispersals, Indicating that the origins of crop cultivation and anfmal husbandry in pre-historic tImes, and therefore of early civilisation, are closely related to the major climatic changes, and more particularly to increased desiccation. These conditions led to the abandonment of the forter hunting grounds in and around the deserts. Toynbee's Interpretatiọ is that, while some hunting tribes, for example, changed their habitat in order got to change their habits and moved Into Bquatoria, others settled in the marshy N1le Valley and evolved a civilieation based on the cultivation of crops.

The nondic fótm of animal husbandry. so characteristic of the arid and scul-arld linds of the Old World, also had Its 
or1gin in pre-historic times. In Toynbee's terminology it represented a response to the challenge of the further increase In desiccation. Toynbee argues that, in the face of this climatic change, the animal husbandmen of the area reacted in different ways. Some migrated to reglons with environnental conditions similar to those to which they were accustomed. Others, abandoned the untenable oasis, they abandoned their former staple of agriculturo-and staked their existence on their latest acquired art, that of the stockbreeder, they becama nomads.

The systems of land use evolved by the animal busbandmen In arid zones, and more particularly by the nomads, in response to these major changes in climate have, according to many authorities lnduced further desiccation with the excessive removal of the vegetative cover. It has been suggested that these man-induced types of desiccation may themselves have led to major grations of peoples such as the two Arab waves across North Africa - the Sons of the Prophet who created the Moorish civilisation of southern Spaln and Morocco, and Later the Bedoulas.' These and other nomad Irruptions may however, have been due to gne of the rhyth-1c alternatives between periods of relative desiccation and bunidity, the occurence of which seems to be indicated by meteorological evidence (ste chapter IV). These fluctuations may also have lad to the occasional encroachaent of the cultivators on the land of the nonde when conditione, becane wore hund and favourable for exop cultivation (eee chapter IV). 
The history of the vegetative cover of the lands in which these events in human and agricultural history took place 18, of course, closely related to the animal husbandry. But the plants were not only grazed and browsed by livestock, the woody vegetation was also cut for fuel and other purposes. In addition, the burning of the vegetation in semi-arid environments has been a major factor in producing and maintaining the existing vegetation cover (see chapter VII). Although it has probably been Induced to some extent by natural causes, fires have also been employed by the hunter in search of his game, by the tribesmen in raids on his nelghbour, and by the herdsman who wishes to eliminate fibrous and unpalatable growth and produce new shoots for his animals (see chapter VII). While fire has been a major factor in the vegetation history of Africa for thousands of years, the degree to which fire operates as a contributing factor for vegetation retrogression naturally varles according to the type of vegetation.

The combined effects of the factors mentioned as having been in effect for centuries in the old World, namely, the development of systems of soclal structure, the adaptation of forms of anteal husbandry to arid and semi-arid conditions, and the reduction, largely by them, of an existing vegetation cover to a type much lower on the ecological ladder, together provide the basic enviroment for animal husbandry in the arid zones of the 01d Horld 
and livestock in such an environment, and of the princlples of conservation of vegetation, sol1 and water, more sultable forms of enterprises have been involved.

The Ifvestock industries of the arid and the semi-arid zones are carried on within the 1 imits imposed by an environment composed of the usual factors of climate, soll and vegetation. The most lmportant factors influencing the present nature and extent of a livestock Industry and the degree to which it can be Improved are, however, blotic in nature. The actual existence of man and his grazing animals in artd and semt-arid zones affects not only these habitats themselves, but also extends the areas of aridity into zones which are not originally of this type (see chapter IV). In the Sahel region, which is the consideration of this paper, the extensive area of true desert and semi-desert would seem to have been gradually extended by misuse, or rather, by excessive use of the land and its vegetative cover. A distinction might be made between the true desert and the man-made sem1-arid land, since it 18 the latter which should be the móst susceptable to improvements (see chapter VII). Research on desert reclamation must be given high priority so that the new desert regions of the southern Sahel can once more be brought into more efficient use for agriculture and grazing.

In line with desert reclamation Just suggested, ecol- 
oglcal management of the natural vegetation through the intelligent control of the grazing practices would seem the most important method of Improving and maintalning resources (see chapters $V$, VI, VII, VIII and IX). However, Intelligent ecological management really means it is necessary to appreciate and apply the principles and techniques of plant geographers and ecologists. In order to plan grazing systems and forms of nomadic and migratory grazing, It 18 necessary to know the vegetation in all its aspects; the ecology and the blology of the different species, with reference to their general phystology, drought resistance, relative palatab1lity and liabllity to damage grazing, and the characteristics of seed germination under the extreme conditions in which the plants are growing. In fact, in the improvement of desert ranges, animal husbandry practices should be directed towards the welfare of plants (see chapter VII).

The faunal components of the blotic complex or bione of the arid and semi-arid Sahellan area must also be considered, particularly the natural wild life and 1 ts grazing and browsing habits. What 11ttle wild life as exists in the Sahel has different grasing habits to that of the domestic animals. Though the wild Iife way graze an area heavily it is not continuous since they' soon move on to another spot. This is In sharp contrast to the continuous and sometimes very heavy grazing of the donestic livestock. Evidence appeare to confirm thls natural practice of the indigenous 


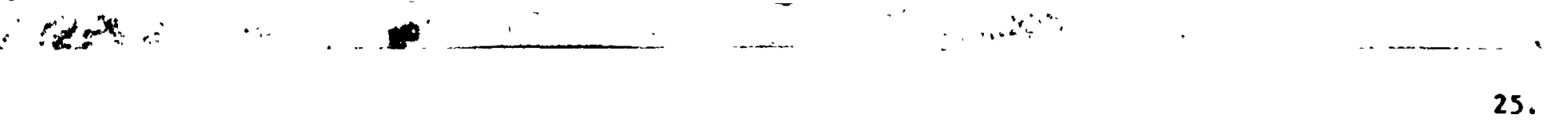

wid life in the arid areas of the Horld, and, the desirability of avolding continuous grazing with the ensulng destruction of vegetation by a concentration of large numbers of starving animals, throughout prolonged drought, at waterpoints?. There may be differences of opinton between experts on the effects of concentrated heavy grazing even if only for a short time. The effects of large numbers of animals, or of a concentration of animals on an unrestricted area, are of ten soll compaction, reduced infiltration of water, reduced run-off and erosion (see chaptery vI and VII).

Besides the questions of vegetation and fauna, it must be remembered that the domestic animals of the old florld desert regions are adapted to ifving in an environment characteriged, in most cases, by great extremes of tepperature combined with low avallability of food and water. In addition to being adapted to wide seasonal varlations in fodder reserves, desert livestock must also be able to move great distances in their seasonal igrations in search of fresh pastures. Any marked improvements . in the ecotypes of the domestic animals on arid and semi-arid lands could tend to make them less able to find and utilize the avallable fodder and so survive under these conditlons. In other words, any tendency to breed semi-desert livestock away from the existing or potential, levels of the fodder reserves must be avolded, unless it 18 clearly poseible to provide a less erratic supply of grazing and fodder of supertor quality to meet the dewands of improved atock (see chapter VII). 
The men who live with and by livestock in arid regions are also an important, if not the dominant factor of the total environment. It is for the Governments to decide, In association with sociologists, livestock speclallsts and the plant ecologists, whether this primitive and rigorous way of 11 fe $1 \mathrm{~s}$ to be regarded as a permanent feature of the modern age, or whether the freedom of the nomadic life should ultimately be replaced by a more prosalc and settled form of existence based on improved livestock and a larger quantity of high quality cultivated fodder (see chapters VII, IX, $X$ and $X I)$. It 18 perhaps doubtful if any major change can be visualised from a land use polnt of view, oring to the Increasing pressure of population on the limfted cultivable land avallable.

Any plan for the economic management and the development of the arid and assoctated semi-arid zones must be based on surveys of the environment in all 1 ts aspects. The area to be covered 18 enormous, while the resources of finance, technical staff and transportation are very limited. It is also possible that the relatively slight Increase in the total returns of livestock products In some of the 01d World desert areas may not Justif extensive and detalled surveys of the type, that have been carried out in more favourable agricultural regions.

As to the econqmic basis of a beef cattle Industry and 


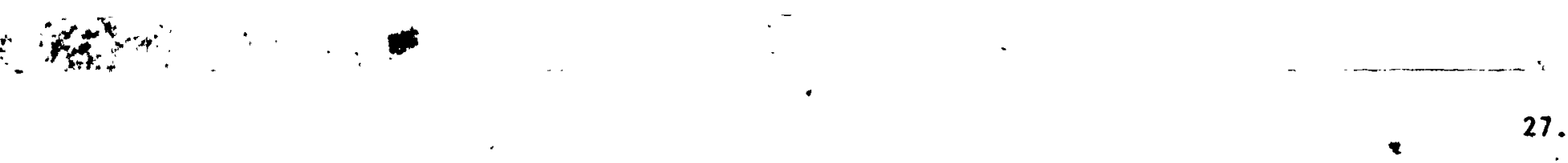




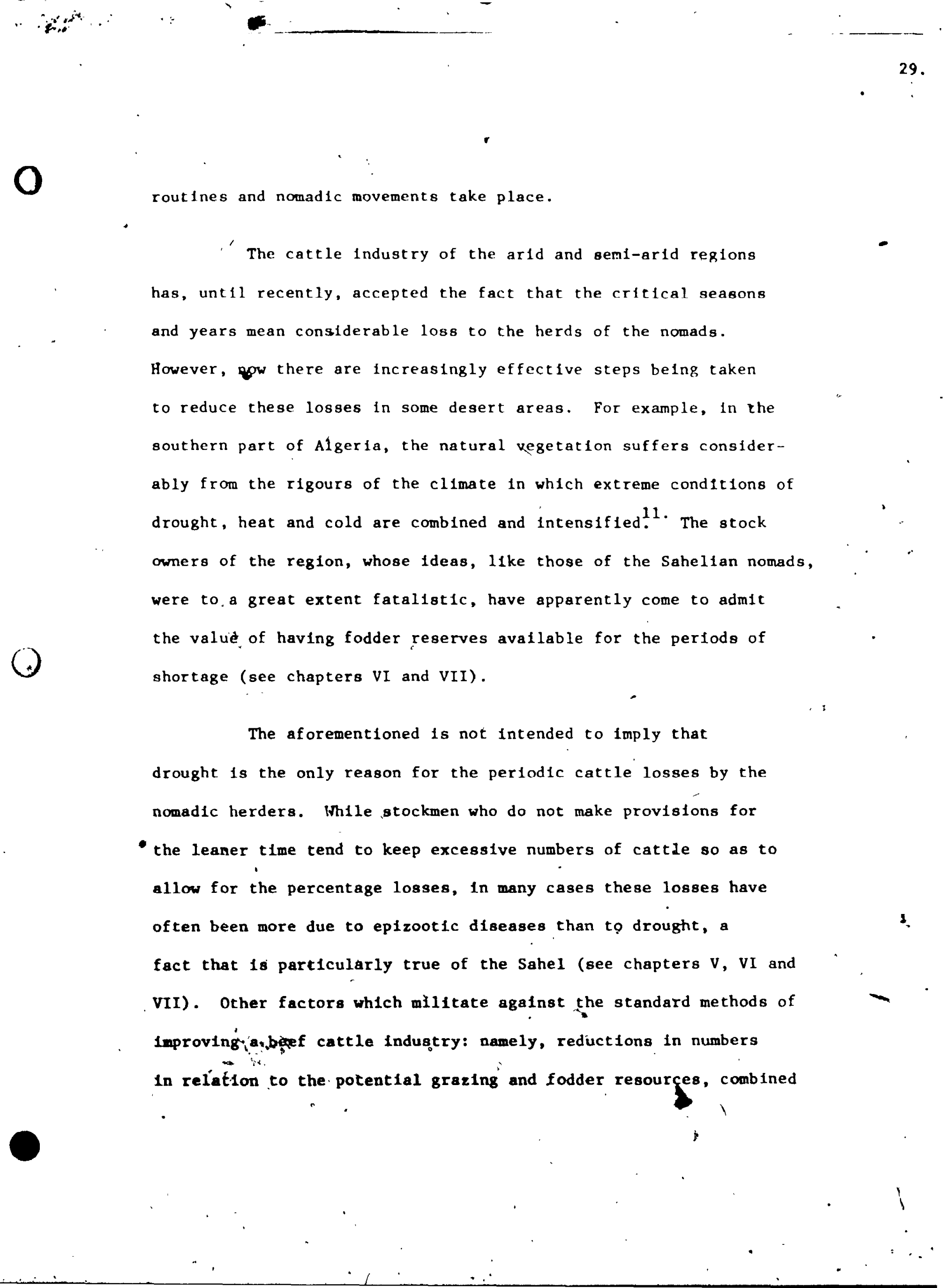


with the 1mprovements in quality through better health and by selection and breeding; arise where cattle represent wealth and are used in barter for food grain or other requirements such as a bride price (see chapters $V$, VI and $Y$.).

\section{THE IMPORTANCE OF BEEF CATTLE IN THE SAHEL}

An1mal husbandry has been a key feature of the Sahel region for many hundreds of years. In pre-biblical times the Sahara was once lush with vegetation from the heavy rains, 12 . and the peoplethere dependant on hunting and flshing for their livelihood. However, with the drying of the Sahara, these people migrated both north and south changing their life styles at the same time. As was mentloned earlier, they adopted animal husbandry and other cultivated the indigenous millet and sorghum. found in their enuironments! During these early, times the clvilizations of this region began to show clear divisions with pastoralists and oasis cultivators Inhabiting the northern region (the sub-Saharan zone of chapter III, Map 2); pastoralists and agriculturallats occupying the middle or Sahelian zone; and agriculturfilst inhabiting the southern region (the Sudantan. zone and further south on Map 2) where, because of the tse-tse $s$ fly, cattle have diffiçuty surviving. Clearly therefore, livestock has been a major factor in the continued ourvival of the people of the six nations of the sahel. This lo particularly 


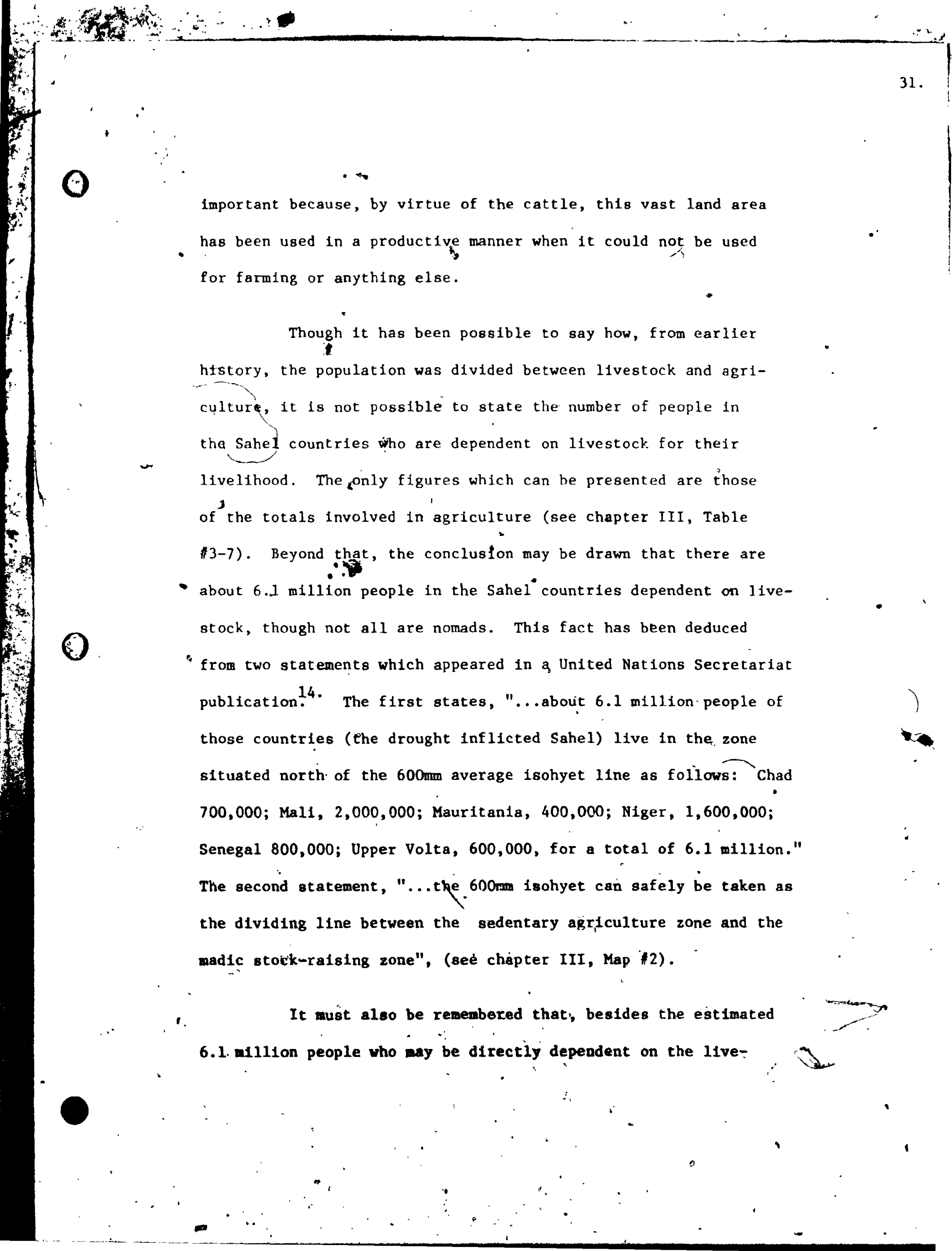


stock, there are a number of others in the economies, including the sedentary farmers, who may be considered as being indirectly dependent on cattle. These would also include a small percentage of the urban population who may be engaged in the processing side of the beef industry, such as the numbers employed in the abattoirs, the meat packing plants, the tanning and leather industries.

While there are no truly accurate figures for the people dependent on cattle, netther are there any true figures for the actual numbers of livestock in the Sahel.region, even though various attempts have been made at calculations and census for some parts of the continent. 16 . For the purpose of this paper, the only figure which w11l be accepted with any credence will be that of the FAO In the 1972 Production Yearbook, Vol. 26, since this is an offictal publication. Table $2-1$, shows the FAO estimates for livestock in the Sahel region for the year 1972 as being 20.7 million cattle, 16.5 million sheep and 20.5 million goats.

There may be a temptation to assume all cattle belong to the nomads but this potnt should be clarified. In times of drought the nomads entrust many of their cattle into the care of the sedentary farmers for safekeeping, and certainly since 1969 they have also slaughtered a large number in order to spare them the effects of the prolonged drought: 
dyty

;

0

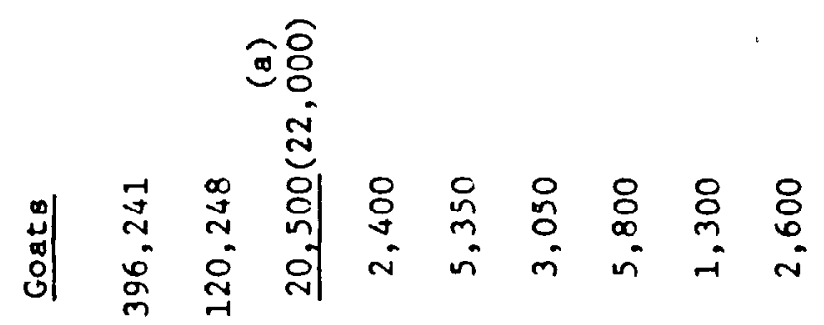

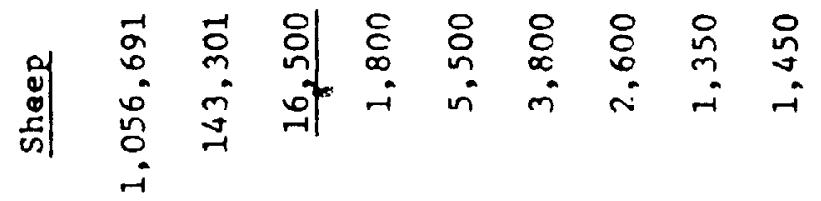

تِ

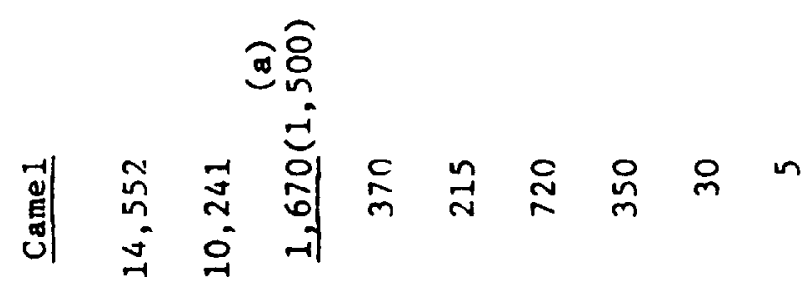

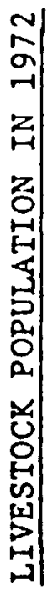

先

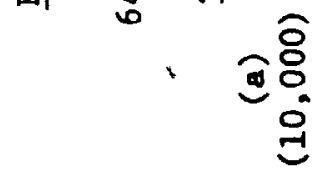

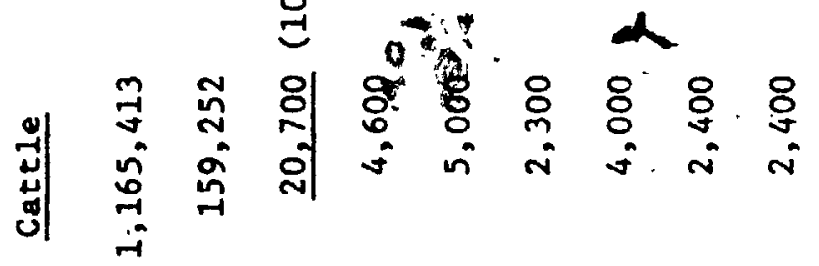

崩|
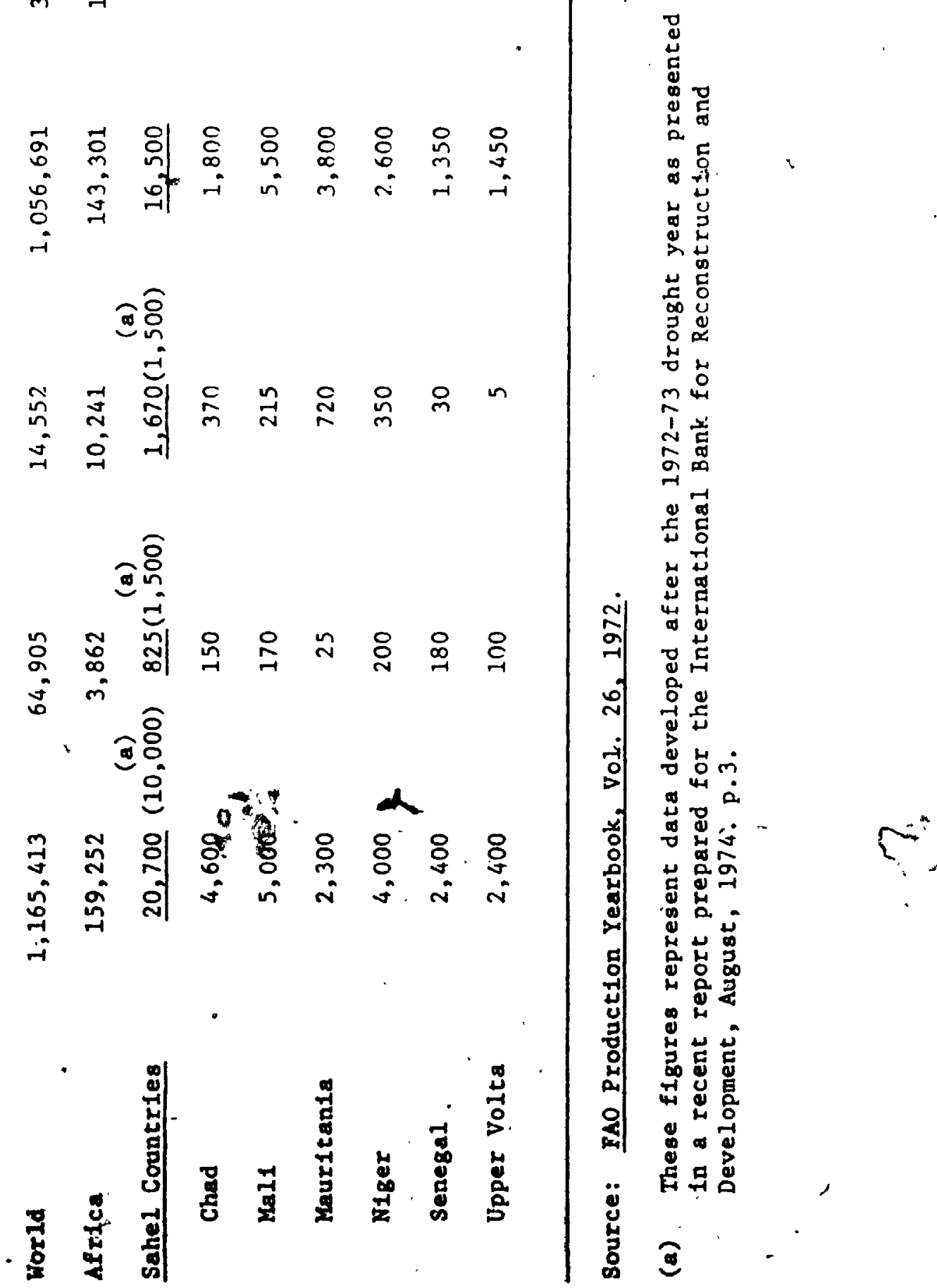
()

While the size of the cattle population in the Sahel is important to this paper, the true economic value ${ }^{17}$ can only be ascertained by examining the financial contributions made by the cattle herds. This importance can be clearly seen from chaptef III, Table 3-10, "Share of livestock exports in GDP and total exports" and also from Table $12-2$ which shows in excess of 20 m1lion head of cattle in the Sahel.

The data in these two tables represents a degree of cattle for the processing industrial sector, though to what extent the processing takes place it is not possible to verify. Certainly, there is some processing as Table $2-2$ indicates with the value of "Selected exports of processed meat and live animals from the Sahel, 1970."

The livestock figures, in terms of their significant share of the total export market, are made all the more remarkablé because, so far, very little has been undertakento organise the marketing of animal products even though all the Sahel countries seem to appreclate the potential for cattle in their recent development plans. This last point just mentioned will be substantiated in the next section. EMPHASIS OA BEEF PRODOCTION IN THE DEVELOPHEAT PLANS

During the ten year period 1971 to 1980 , the Government of Chad Intends to give prlority to cash eropt which are 1ikely 

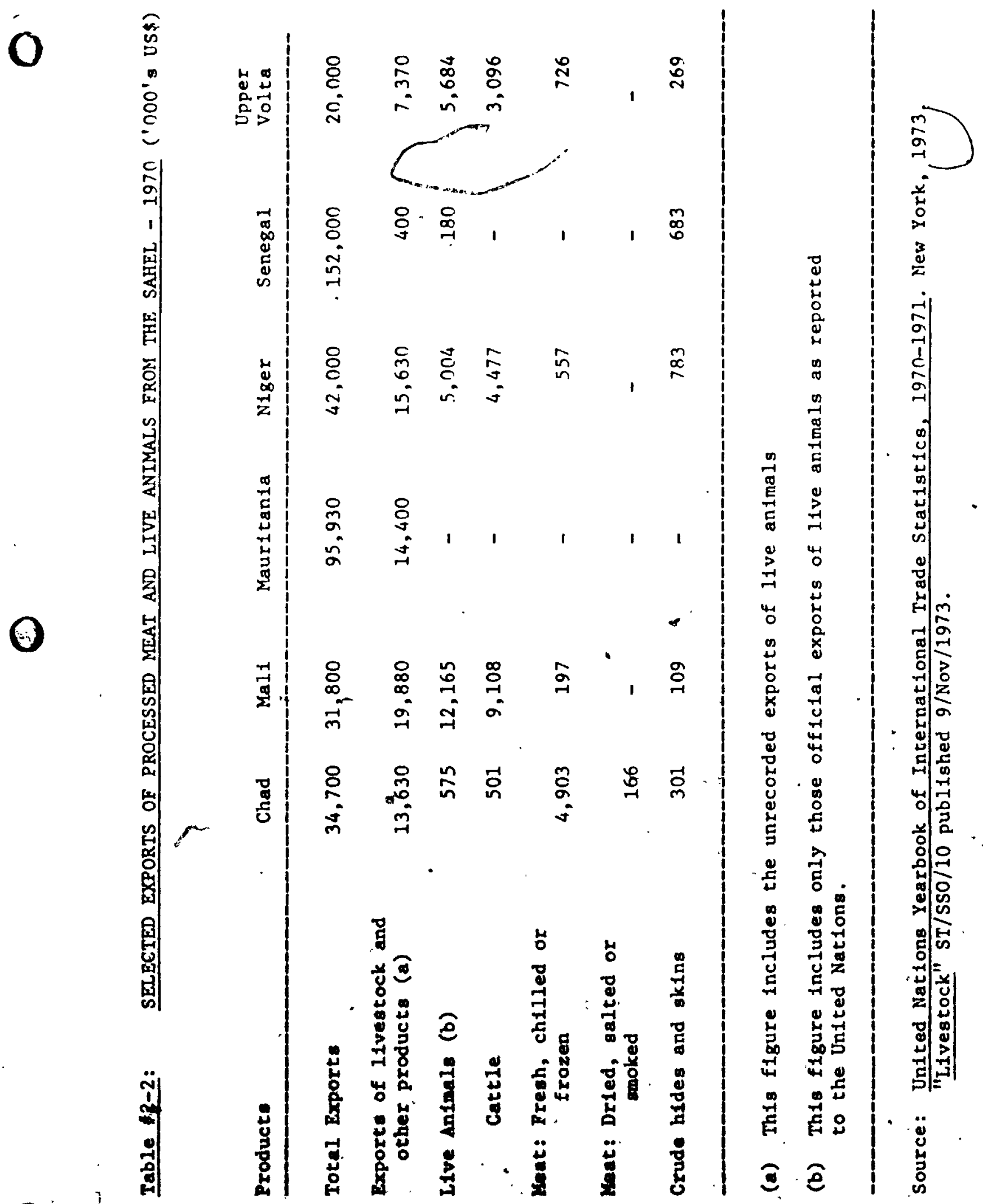
to bring about rapid increases in the incomes of Chad farmers. However, since livestock accounts for over 307 , of Chad's exports (see chapter III, Table 3-10), "The Government Intends to give more importance to animal husbandry in the 1970s. It has set itself the target of doubling refrigerated meat exports by 1980 to reach the level of 25,000 cons. To this end projects have been prepared for integration within the Second Development Plan", covering the development of cattle tracks, water, pastures, ranches and animal health.

Niger is another country of the Sahel which enjoys considerable Benefits from the exports of cattle to the tune of $28.8 \%$ of total exports in 1970." Thus, "The government of the Niger is giving priority, in the stock-raising sector, to qualItative improvement of the herd, on which over-all production growth depends" 20.

The situation in Mali with regard to beef is even more critical because cattle 18 the mainstay of the Mali exports (see chapter III, Table 3-10). "Henceforth, greater efforts must be devoted to the economic and commercial aspects in order to encourage producers to respond to consumer demands for meat..."21.

Upper Volta clearly gubscribes to the Importance of beef cattle by providing for bubstantial investments to develop 
3

the Industry in the 1972-1976 Plan. Such Investment would help develop abattoirs, storage refrigeration, feed-lots, markets, cattle runs and pastures. 22.

Senegal will be concentrating on improving the quality of cattle, developing stock farms and the organisation of markets and exports during the Ten Year Plan 1970-1980.3. This is being done, "In order to restore antmal hushandry to a position more in keeping with its economic importance." 24 .

All the statements quoted in the previous paragraphs were statements of 'intent' taken from the individual development plans. Unfortunately, no policy measures have been taken in the countries thus far, nor have monies been allocated or spent. A situation which may be considered to be entirely due to the drought emergency which has claimed all the avallable resources to stem the probables, at least in the short run.

However, these same statements do indicate the emphasis which each of the nations is planning to place on beef cattle. It is interesting to note that these same plans make 11 tite, or no wention about the production of sheep ahd goats. Clearly, Table 1-1 show the importance of these types of livestock which are raised by both the nomads and the sedentary farmers. But, not too much has been done thus far to further develop the Industiry of goats and sheep, and it is not the intention of this paper 
to even consider them. However, it should be mentioned that parallel to beef industry development, there would also be an opportunity to introduce improved breeds of sheep and goats since they too would be able to benefit from the improved pastures, water resources, infrastructure, health regulations. and markets.

SURMARY

This chapter provided a synopsis of the historical and social aspects of animal husbandry in the 01d Horld areas, with particular reference to the Sahel. After which, the "Importance of beef cattle in the Sahel" was considered with the Inclusion of substantiating quotations taken from the Development Plans of the Sahel countries.

Having thus provided an introduction to the nomads of the Sahel and their dependance upon cattle, it is now possible to examine the situation in the Sahel region in more detall. Hence, the next chapter will discuss the geography and the economies of the Sahelian countries of West Afrca, thereby setting the stage for an evaluation of the possible development of a substantial Beef Cattle Industry in the six countries of the region. 


\section{FOOTNOTES}

1. "The Old World" is that area around the Sahara and the deserts of Arabia, Sind, Central Asia and the Gobi.

2. The regtion called the Sahe1, for the purposes of this paper, is defined in chapter III.

3. Sauer, C.0., "Agricultural Origins and Dispersals", Bowman Memorial Lectures, American Geographic Society, 1952. p.11n.

4. Toynbee, A.J., A Study of History, Oxford University Press, 1947. p.689.

5. Ibid., P.164 ff.

6. D. Brown, "Methods of Surveying and Measuring Vegetation", Commonwealth Bureau of Pastures and Field Crops: Bulletin \$42, 1954. P.223.

7. Similar experience would be the buffalo of the North American plains and the seasonal migration of game from the southern Sudan to Uganda and Kenya.

8. This point will be discussed more fully later in this paper since it is of key importance for successful development of any economy.

9. K.L. Sjorberg and S, Persson, Cattle Production In Africa, Rural Development Study No. 2, College of Agriculture, Sweden, March, 1974.

10. F.A.0. Report of the Third FAO Meeting on Livestock Production In the Americas, Rome, June 1955. p. 170.

11. M. Schaefer, "Conserving Födder and Bullding up Fodder Reserves for the annual Perlods of Drought in the Pre-Sahellan Steppe". Paper presented at the 2nd Meeting of the FAO Working Party on

- Mediterranean Pastures and Fodder Development (unpublished 1953).

12. Neolithic negrold groups spread Into the fertile Sahara from the Sudan about 5,000 years ago. See Lloyd Cahot Briggs, Tribes of the Sahara, Harvard University Press, 1960. p.37. 
13. Social Institutions, published by the UN, ST/SSO/23, March, 1974. P.10.

14. Livestock, published by the UN, ST/SSO/10. November 1973. p.2.

15. No f1gures were avallable from any source as to how many people work in the meat processing industry for the Sahel countries.

16. The census of Bernus for Niger 1970-1972 and the calculat tons of Michel Baumer for Sudan 1968. Both are cited in Livestock, op.cit.

17. The term "true economic value" has been used although it might be said that, in more-or-less non-or-semi-monetary tribal economy based around cattle the "true economic value" of the herds relate only in small part to their financial contribution.

18. Country and Intercountry Programing - Chad, published by the UN, UNDP/GC/CHD/R.1. December 1971. P.22.

19. Country and Interscountry Programing - Niger, published by the UN, UNDP/GC/NER/Rev. 1. October 1973. p.15.

20. Ibid., p.16.

21. Country and Intercountry Programing - Mal1, published by the UN, UNDP/GC/MLI/R.1. October, 1973. p.15.

22. Country and Intercountry Programing - Upper Volta, published by the UN, UNDP/UPV/R.1. March, 1973. p.22

23. Country and Intercountry Programing - Senegal, published by . the UN, UNDP/GC/SEN/R.1. September, 1973. p.20.

24. Ibid., p.20. 


\section{INTRODUCTION}

This chapter is an attempt to provide a plcture of the Sahel as it existed prior to, and during the early years of the recent major drought (detalls of the drought are provided in chapter IV). The region of Africa known as the Sahel is defined both geographically and climatically with some information being provided concerning the population, vegetation, land use and water systems. After this description of the 'God given' natural aspects of the Sahel, the chapter then proceeds to describe what 'Economic Man' has managed to do with this somewhat harsh climatic area of the World. In order to assess the contribution of Man, it is deemed necessary to view such measurable areas as National Accounts, Agriculture and Manufacturing, Exports, Imports and Balance of Payments, Savings, Investments and Aid. During the course of describing each facet of the economy's of the Sahel countries tt has been possible, for the most part, to provide reasons for the poor showing of these countries when compared to other developing nations.

\section{GEOGRAPHIC LOCATION AND POPULATION}

The Sahel 18 that vast area which extends along the 
southern fringe of the Sahara desert incorporating major por-

tlons of the countries of Senegal, Mauritania, Mali, Upper Volta, Niger and Chad (all statistics presented herein pertain to the whole country since it is not possible to separate only those figures which relate to the Sahel portion). Globally it may be designated as being between $18 \mathrm{~W}$ to $24 \mathrm{E}$ longltudes and latitudes $4 \mathrm{~N}$ to $24 \mathrm{~N}$ (see Map \#1).

\section{MAP}

THE COUNTRIES WHICH FORM THE SAHEL

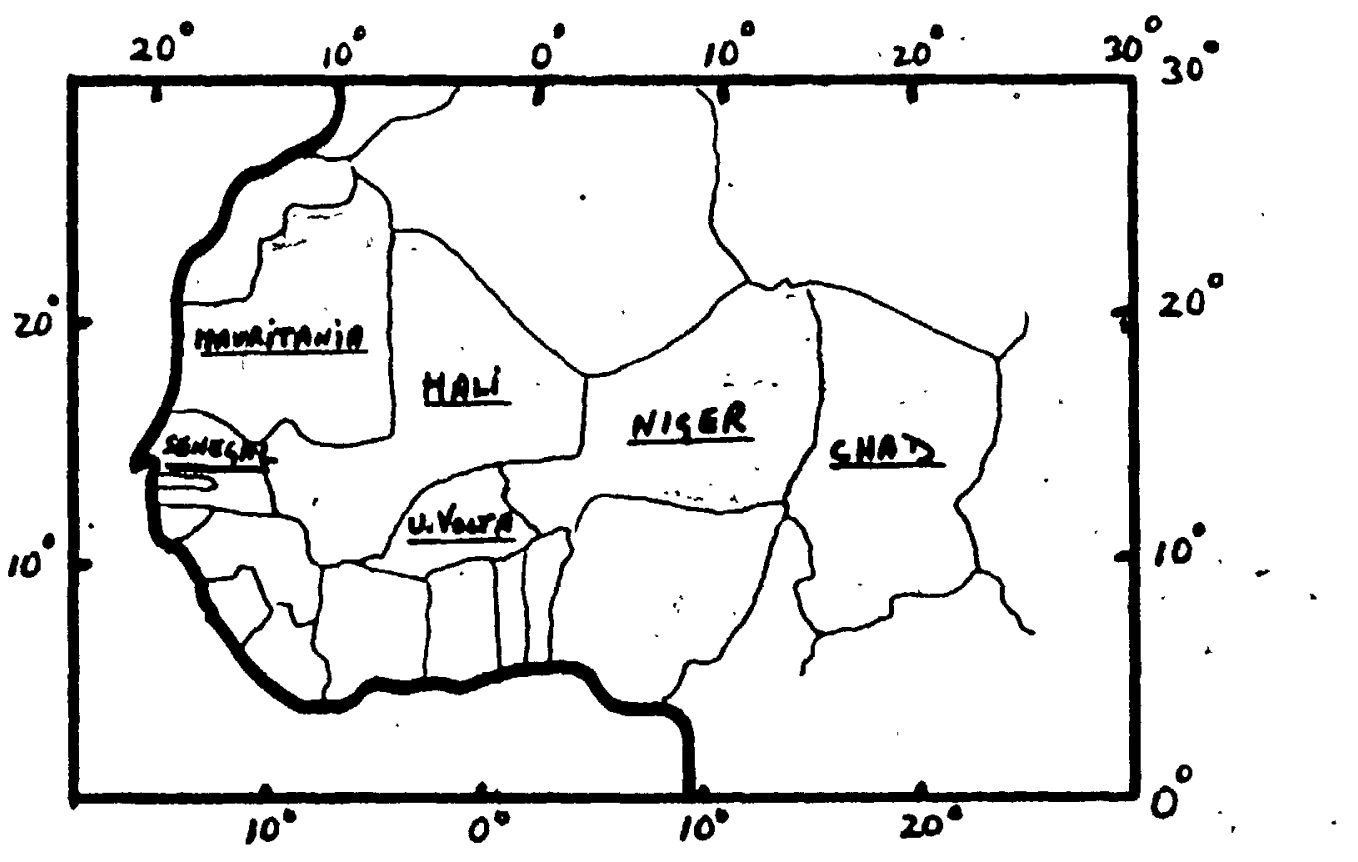

The land area of the Sahel countrles comprise one-sixth of the total land mass of the African continent. However, In this, large, fairly artd land mass are to be found only one-elghteenth of the total population of the entire continent of Africa. In Táble $\$ 3-1$, 

is shown the corresponding population density as being only 4.5 persons per $\mathrm{km}^{2}$ while the remainder of the continent has a density of $11.9 \mathrm{~km}^{2}$.

Table $3-2$, shows the relevant population data with which 'development economists' must concern themselves when they are planning the future development of the Sahel countries. It will be noted that the population growth rate has been fairly constant during the perlod shown. This may be considered to be a reflection of the fact that all the figures listed are estimates, with the except of Upper Volta in 1960 when a census was undertaken. The population for the Sahel countries is predicted as being close to 30 million by 1980 , which is an increase of 6 million from that of 1970 . Of the present population, only about 20\% live in the area actually referred to as the Sahel (a point more properly clarified when describing the nomads in chapter IV), though $88 \%$ of the total population is rural and engaged in agriculture (see Table $(3-7)$. With what is known of the past performance of the refional economy, these figures ratse disturbing questions about the capacity of these countries to cope with the anticipated demands of future deyelopment.

\section{CLIMATE AND VEGETATION}

The countries of the Sahel may be clearly sub-divided Into three main climatic zones which are based entirely on the 


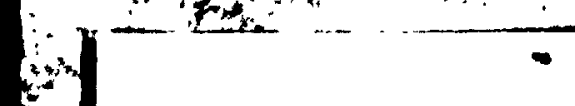

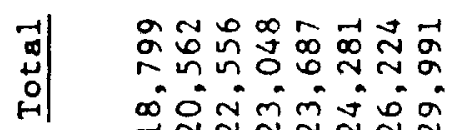

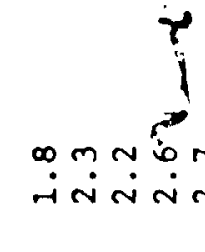

\begin{tabular}{l|l} 
\pm \\
0 \\
0 \\
0 \\
0
\end{tabular}

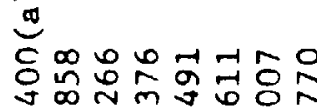

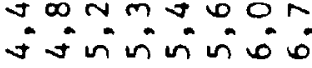

क्ञ

음은ํํำกำ

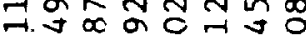

लिंलिंड:

$\operatorname{mag} 2$

iñ $\dot{N}$.

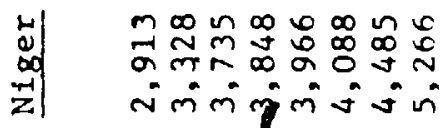

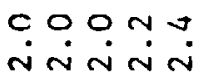

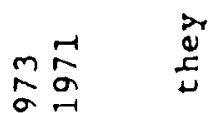

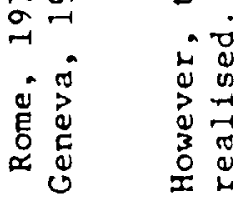

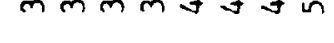

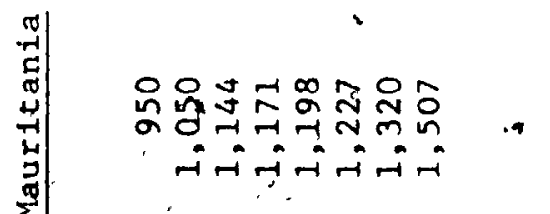

ก

त्रंजिल

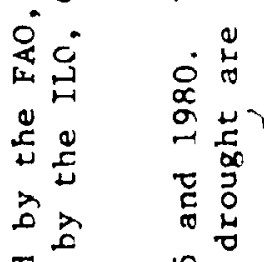

营

蛋 $\frac{\tilde{\sigma}}{2}$

8

究

牙|

men $\frac{1}{4}$

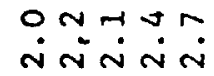

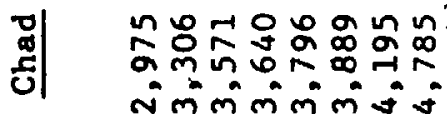

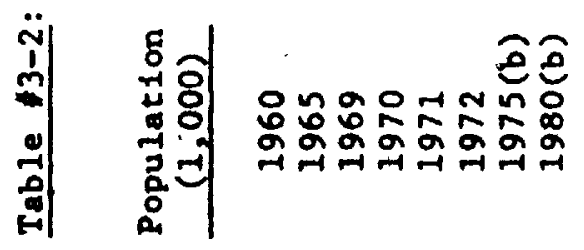

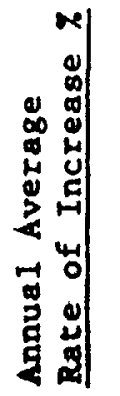

Hanon

nमiñ
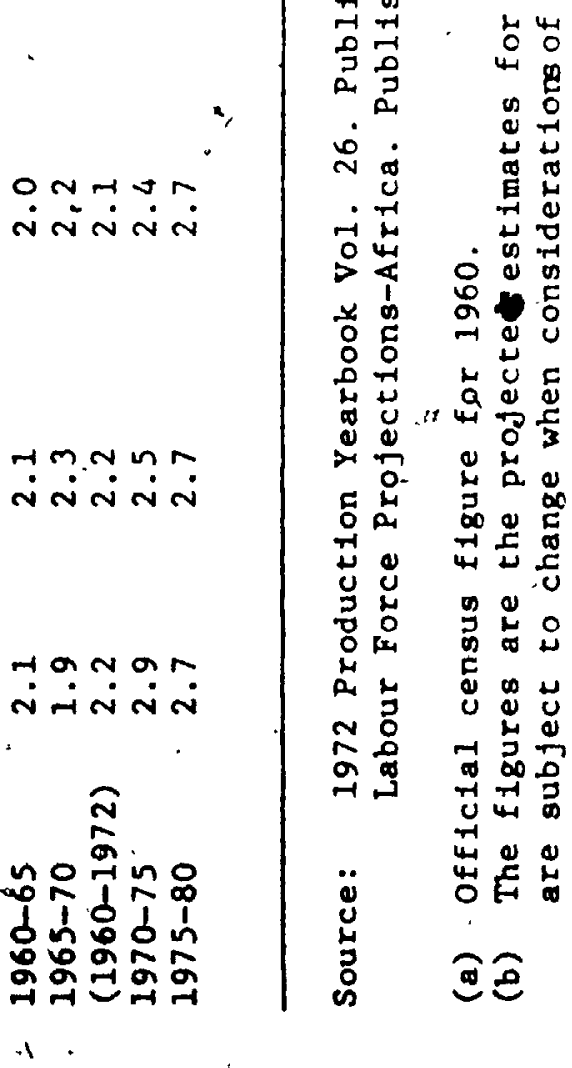
annual rainfall distribution (see Map 12 ). Through the use of 1sohyets three ecological zones can be delineated:
a. The Sub-Saharan Zone
b. The Sahelian Zone
c. The Sudantan Zone

It is really the first two zones which are the concern of this paper; in fact, more spectfically that region lying between the $100 \mathrm{~mm}$ and the $600 \mathrm{~mm}$ isohyets which has been most severely affected by the current drought.

It should be stated that the rainfall really only occurs during approximately a sixty day period from early July to early September (slight rains do fall in June). The remalning months of the year form the long, hot, dry season during which time the Harmattan blows. 3 .

Though this would conjure up a picture of a totally arid zone punctuated by a brief period of rain each year, the area is not totally devold of hydraulic resources. These water resources include the Lake Chad system, the Volta rivers, the Senegal river and the Niger.

Unfortunately, the rains have been considerably reduced during the past few years leaving the rivers much below their normal levels. (see Table $3-3$ ); the lakes having suffered in a similar manner as is indicated by Chart $3-1$, representing Lake Chad. 


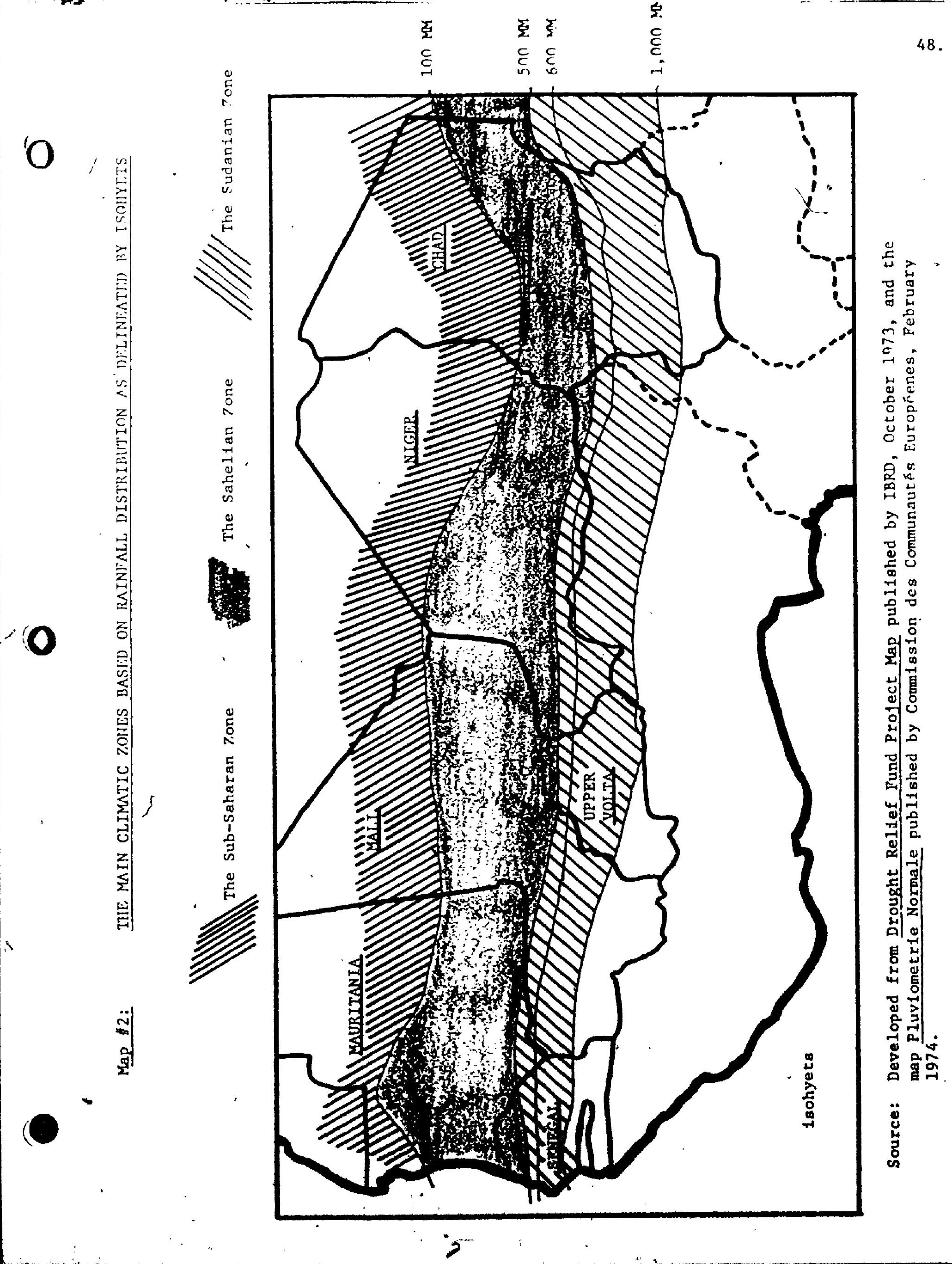




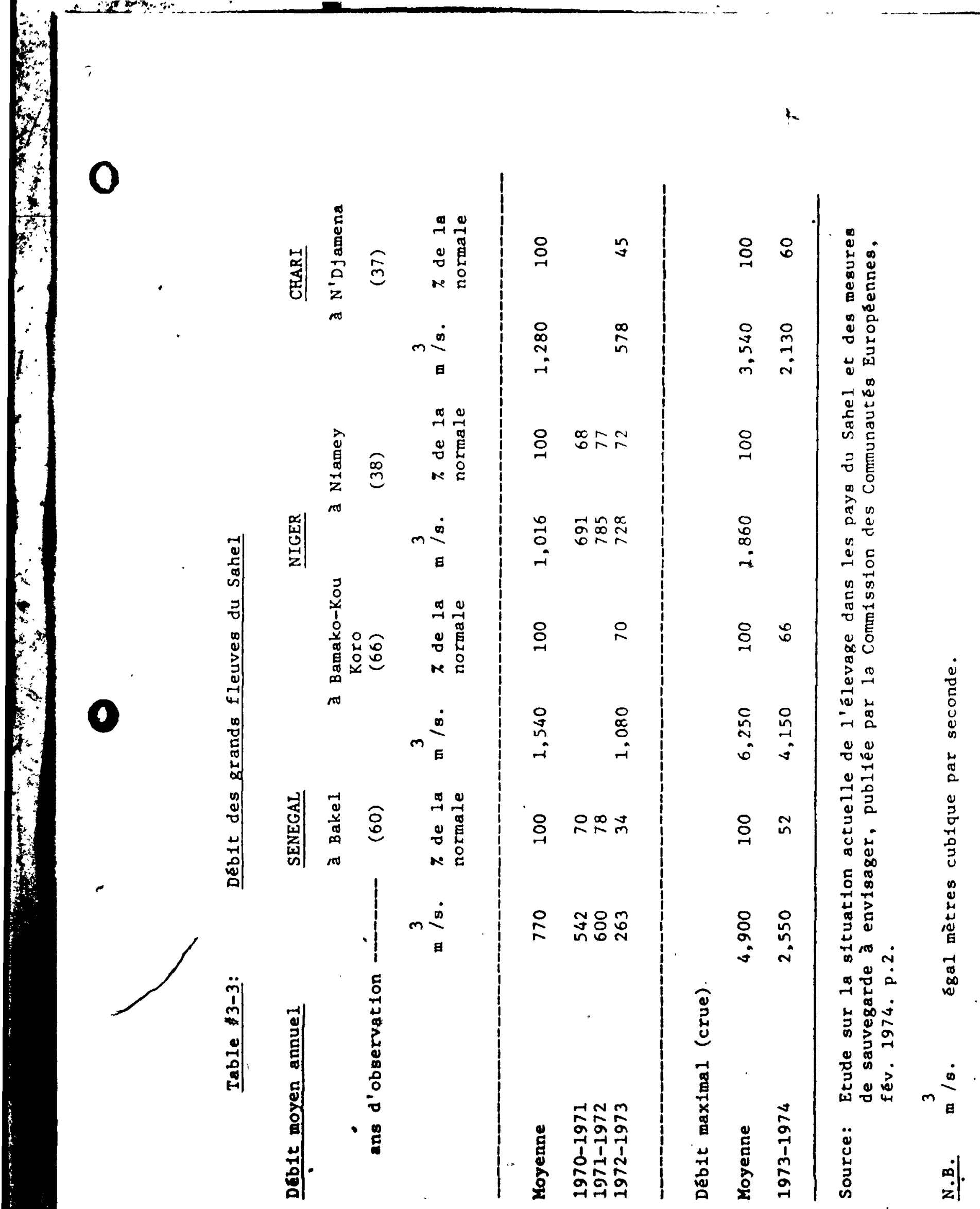




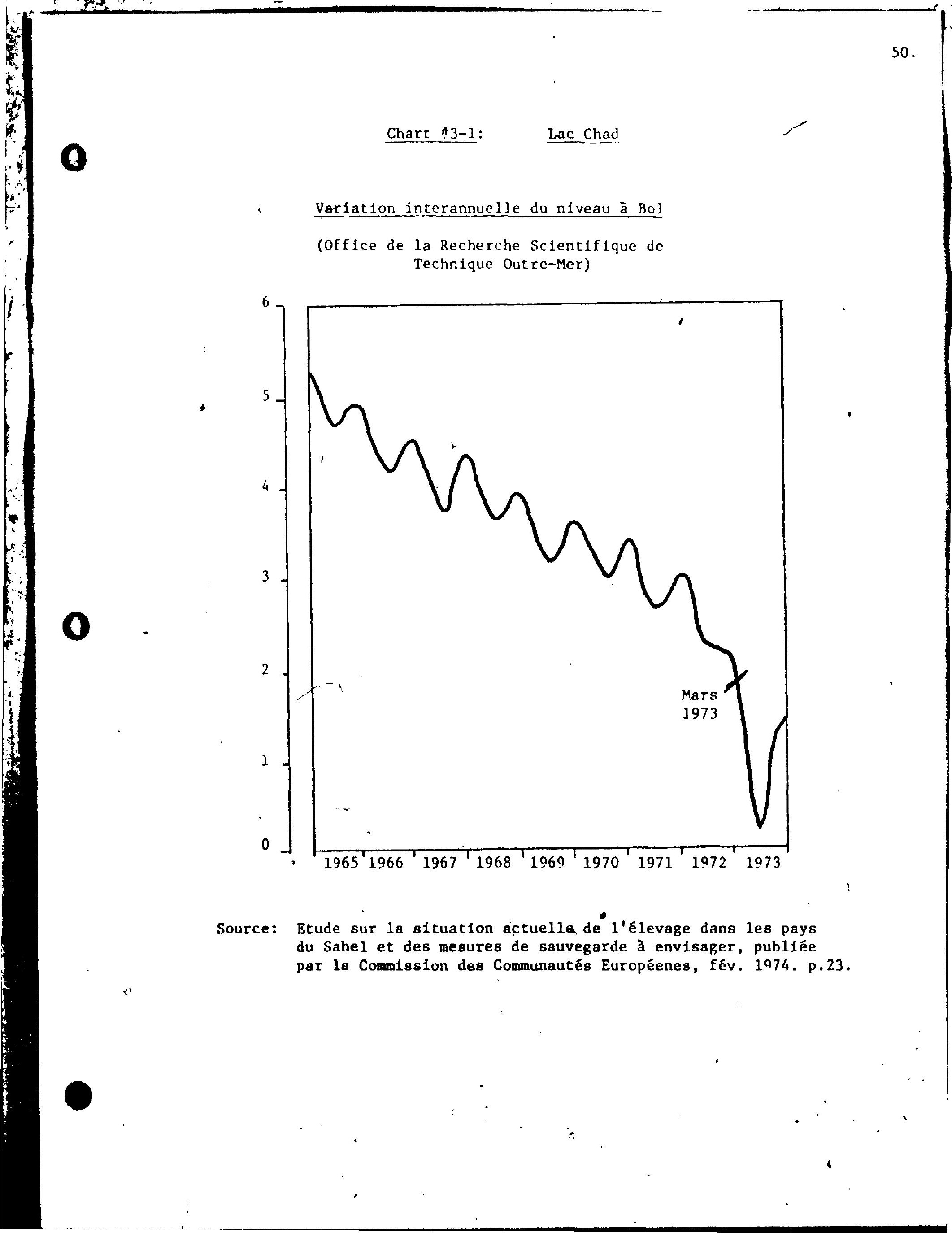


May 3, shows the rainfall decline for 1973 with a table appended for the 1972 rainfall decline. The vastness of the area affected Is also clearly indicated by May $\$ 3$.

It should also be noted however, that despite the lack of rainfall there would seem to be a more than adequate sub-surface water table in the region. 4 . More mention will be made of the water resource later in the appropriate chapter of this paper when its relevance to the livestock development strategy is considered.

\section{Concerning the vegetation of the three zones defined,} a brief description of each will be provided thereby allowing the development of more accurate picture of the total region.

a. The Sub-Sabaran Zone: Th1s northern section of the drought stricken axea is really total desert having less than $100 \mathrm{~mm}$ of ralnfall per year (see Map 2 ). The zone 18 mostly very hot and dry being characterized by sandy, pebb1y soll with sparse natural vegetation which 18 barely able to support human 1ife. Nevertheless, some farmers do exist and they are able to produce dates and cereals around the scattered oases. The population consists of nomadic herdsmen for the most part, who depend on animal husbandry (camels, cattle, goats and sheep) for their livelthood. This nomadic population is entirely dependent on their herds for their needs, trading with the farmers for grain, and as a consequence their 


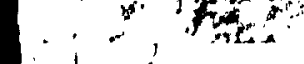

52.

0
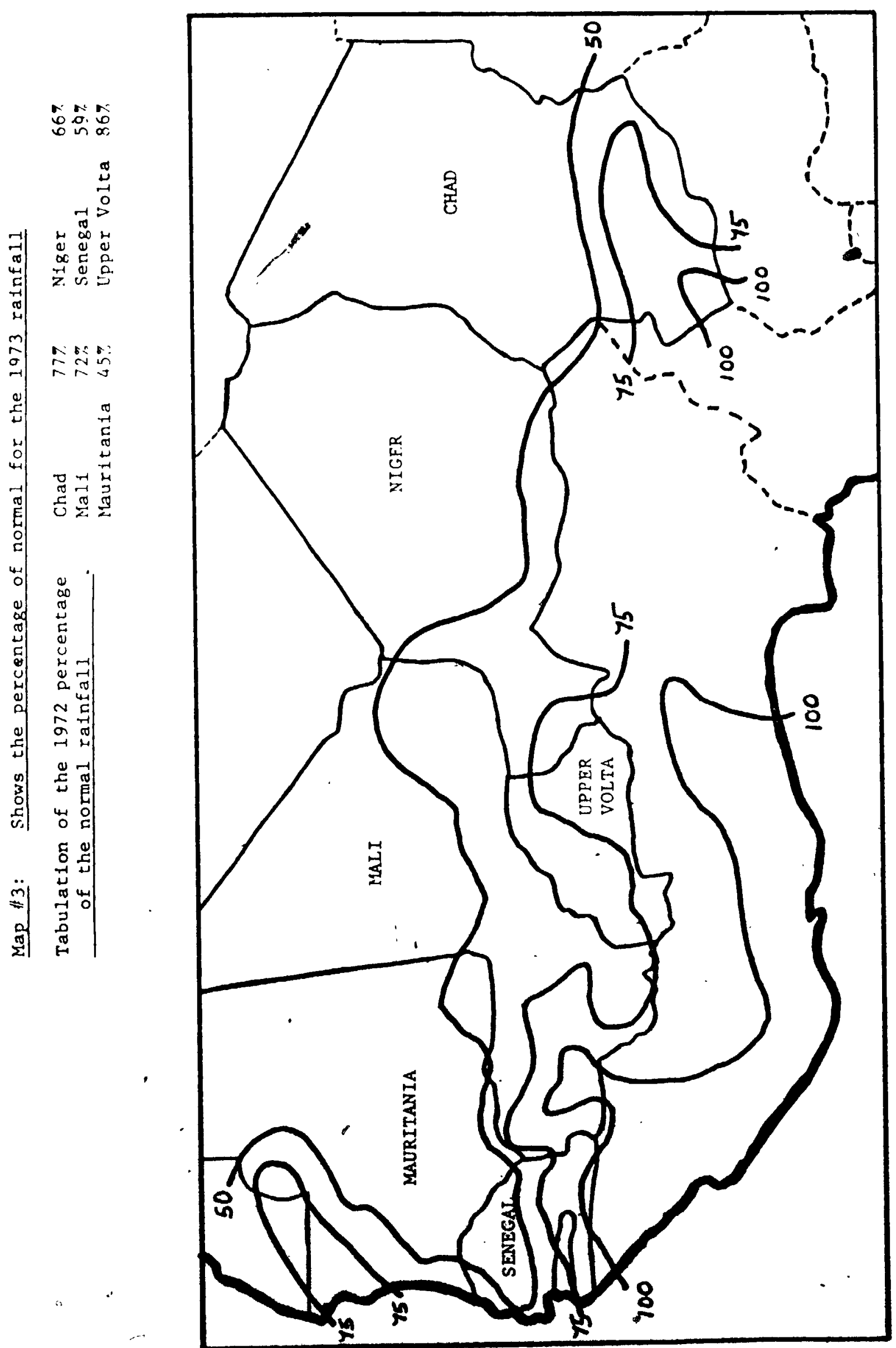

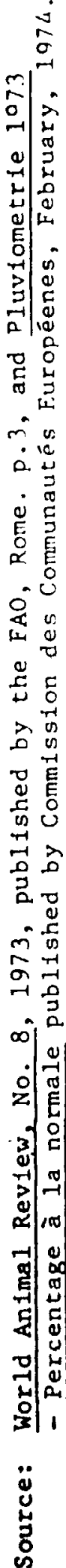

बेन

0 
diet, while high in protein, is nevertheless unbalanced and low in calories. 5 .

b. The Sahelian Zone: Th1s zone is located between the $100 \mathrm{~mm}$ and $500 \mathrm{~mm}$ isohyets (see Map 2). The natural vegetation runs from a sandy soll in the north to scrubby savanna in the southern part of this zone. However, the entire has, in the main, a sparse covering of thorny or drought resistant trees. During the rainy season the whole area becomes covered with short grasses which are more than adequate to allow extensive grazing for, more than two-thirds of the livestock of the Sahel countries. ${ }^{6}$. In addition to this being the main cattle raising region of the Sahel (see Map $\$ 4$ ), there is some seasonal farming throughout the zone with permanent agricultural cultivation in the irrigated areas adfacent to the main rivers and their tributaries.

Much of this zone is a plateau over 500 feet above mean sea-level. It is this elevation combined with the arid climate which means freedom from a number of the insect-borne diseases which plague other areas of Africa. This is one of the main reasons that this ecological zone supports so much livestock. However, it is the long dry season which necessit tates the nomadic existence of the herdsmen, since they must constant ly be on the move to new pastures and water points. 
$\therefore h_{n}$ 
c. The Sudanian Zone: While climatically the zone stretches south from the $500 \mathrm{~mm}$ isohyet to the $1,000 \mathrm{~mm}$ 1sohyet, the area which is of concern in this paper only extends to the $600 \mathrm{~mm}$ isohyet (see Map 2).

The zone consists mainly of agricultural and sedentary farmers. However, the pastural land is more abundant and of tetter quality for grazing than in any other area. This is due to the wet lowlands and the scrubbly savanna. But the lower elevation and the condition of higher humldity is more conducive to disease, both for humans and cattle, and thus livestock are found in considerably less numbers than in the Sahelian ecological zone. It should also be noted that most of the large towns and the majority of the population of the Sahel countries live in this climatic zone.

\section{ECONOMIC BACKGROUND}

The countries of the Sahel, with the exception of Senegal and Maurltania, rank among the poorest in the World having per cap1ta Gross Domestic Product's (GDP) of below $\$ 100$ (see Table 3-4).

a. National Accounts: For the majority of the population, per capita income has not increased since 1960, in fact for many It may even have declined. While the GDP shows varled growth rates (see Table $3-5$ ), the increment in GDP has not ,been strong enough to generate an overall increase in the per capita 
Table 3-4: GROSS NATIONAL PRODUCT PER CAPITA (1972) FOR THE

\begin{tabular}{|c|c|c|c|c|}
\hline Country & $\begin{array}{l}\text { GrlP per } \\
\text { Capita }\end{array}$ & Country & $\begin{array}{l}\text { GNP per } \\
\text { Caplta }\end{array}$ & (S) \\
\hline China, Rep. of & 490 & Cameroon & - 200 & \\
\hline I ran & 490 & Bolivia & 200 & \\
\hline Dominican Rep. & 480 & Slerra Leone & 190 & \\
\hline Nicaragua & 470 & Maur 1tania & 180 & \\
\hline Cuba & 450 & Vlet-Nam Rep. & 170 & \\
\hline Malaysia & 430 & Chlna, People's Rep. & 170 & \\
\hline Algeria & 430 & Togo & 160 & \\
\hline Guatemala & 420 & Central African Rep. & 160 & \\
\hline Colombia & 400 & Uganda & 150 & \\
\hline Angola & 390 & Malagasy Rep. & 140 & \\
\hline Mongolia & 380 & Kenya & 170 & Upper Volta \\
\hline Zambia & 380 & Nigeria & 130 & Burund $\mathrm{i}$ \\
\hline Tunisia & 380 & Pakistan & 130 & Bangladesh \\
\hline I $r d q$ & 370 & Laos & 130 & Rwanda \\
\hline Turkey & 370 & Haiti & 130 & \\
\hline Ecuador & 360 & Khmer Rep. & 120 & \\
\hline El Salvador & 340 & Sudan & 120 & \\
\hline Ivory Coast & 340 & Tanzania & 120 & \\
\hline Rhodesia & 340 & India & 110 & \\
\hline Korea, Dem. Rep. & 320 & Dahomey & 110 & \\
\hline Honduras & 320 & Sr」 Lanka & 110 & \\
\hline Paraguay & 320 & Viet-Nam, Dem. Rep. & 110 & \\
\hline Syria Arb Rep. & 320 & 7.aire & 100 & \\
\hline Korea, Rep. & 310 & Yemen, People's Red. & 100 & \\
\hline Mozamblque & 300 & Malawi & 100 & \\
\hline Ghana & 300 & Niger & 90 & \\
\hline Congo, People's Rep. & 300 & Indonesia & 90 & \\
\hline Papua New Guinea & 290 & Yemen Arab Rep. & 90 & \\
\hline Jordan & 270 & Burma & 90 & \\
\hline Morocco & 270 & Chad & 80 & \\
\hline Senegal & 260 & Ethtopla & 80 & \\
\hline Liberia & 250 & Nepal & 80 & \\
\hline Egypt, Arab Rep. & -240 & Afghanistan & 80 & \\
\hline Ph1lippines & 220 & Somal1a & 80 & \\
\hline Thatland & 220 & Ma11 & 80 & \\
\hline
\end{tabular}

Source: World Bank Atlas, published by the International Bank for Reconstruction and Development, 1974. p.7. 

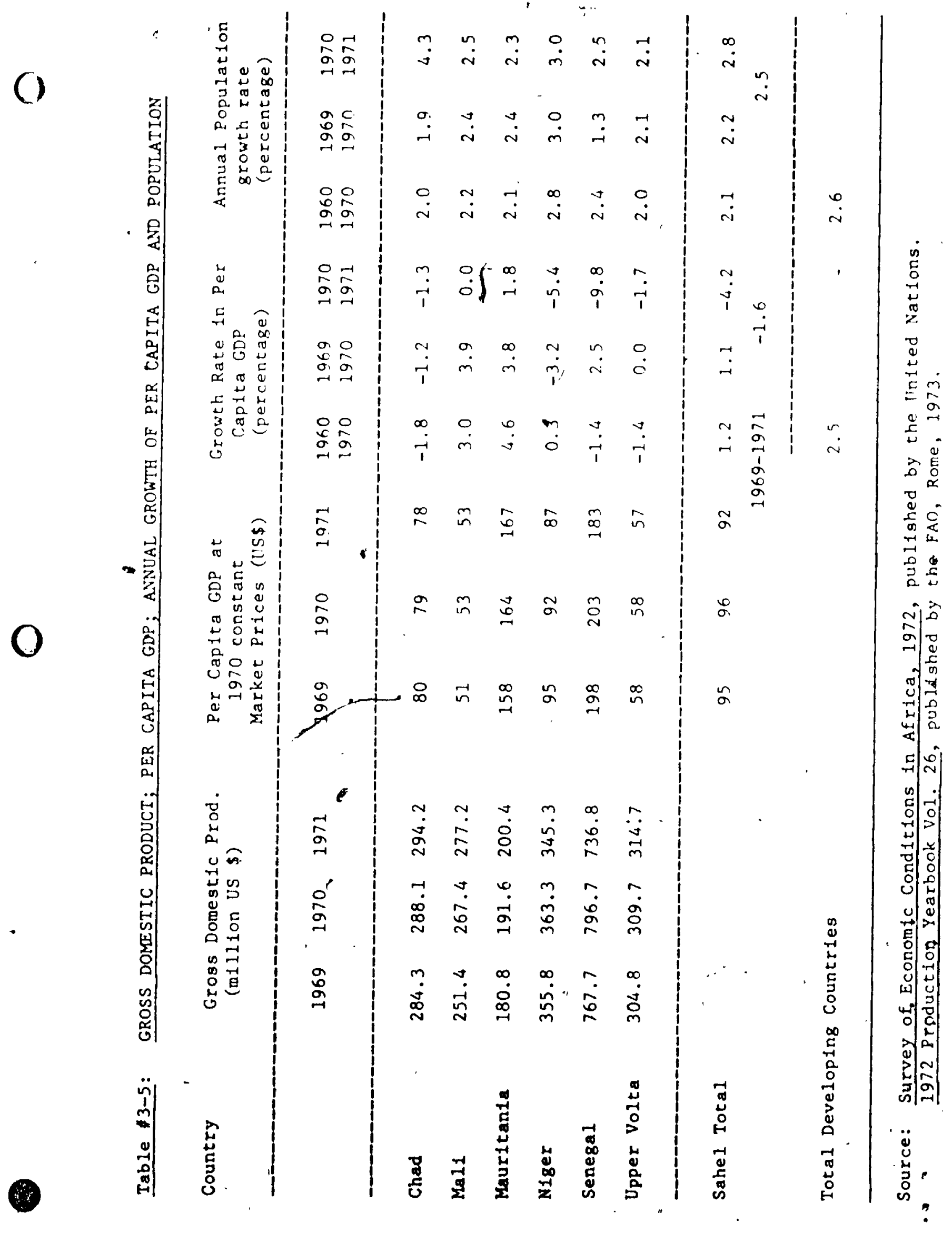

0

$\stackrel{\infty}{\stackrel{1}{0} 0}$

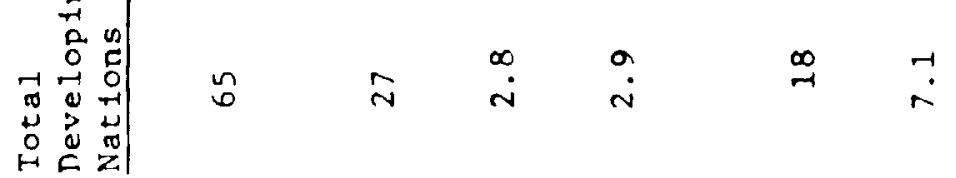

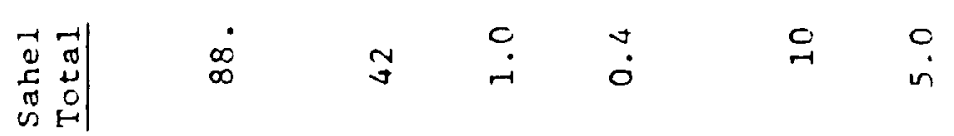

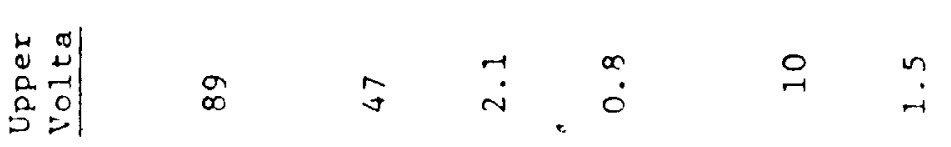

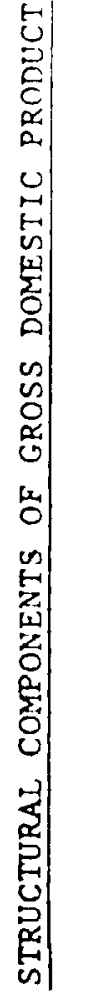<smiles></smiles>

$\begin{array}{lllll}N & 0 & i & m & m\end{array}$

4
0
$\infty$
$z$
$z$

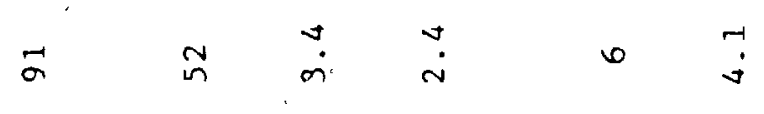

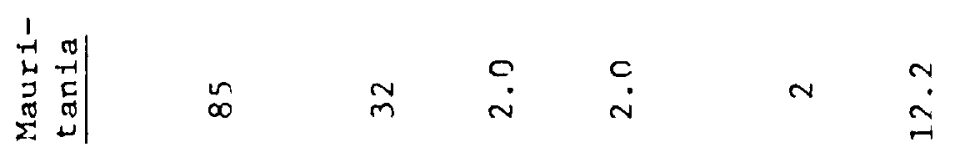

$\begin{array}{lllllll}\pi & \pi & 0 & 0 & 0 & 0 & 0\end{array}$

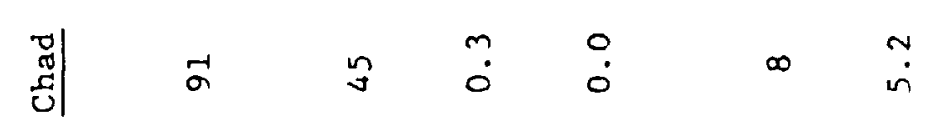

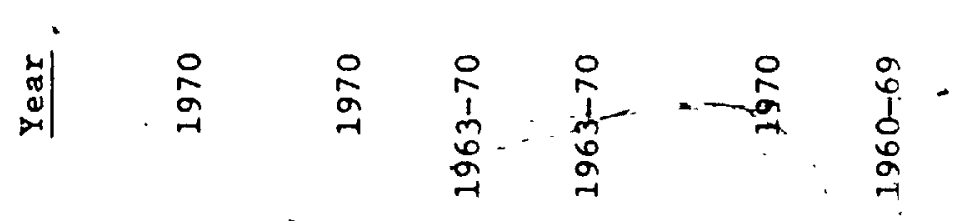

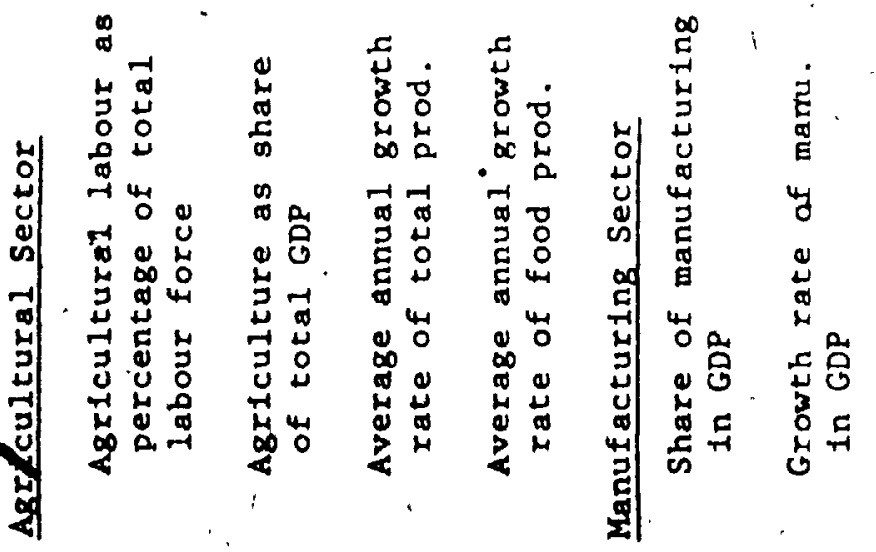

点

$4 \stackrel{m}{g}$

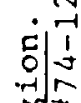

od

$\approx$

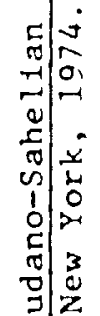

|

空

?ेّ

我

ป⿱宀 犬⿱

잉

包的

द्रे

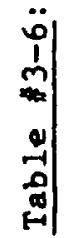

की

$\ddot{j}$ 
O

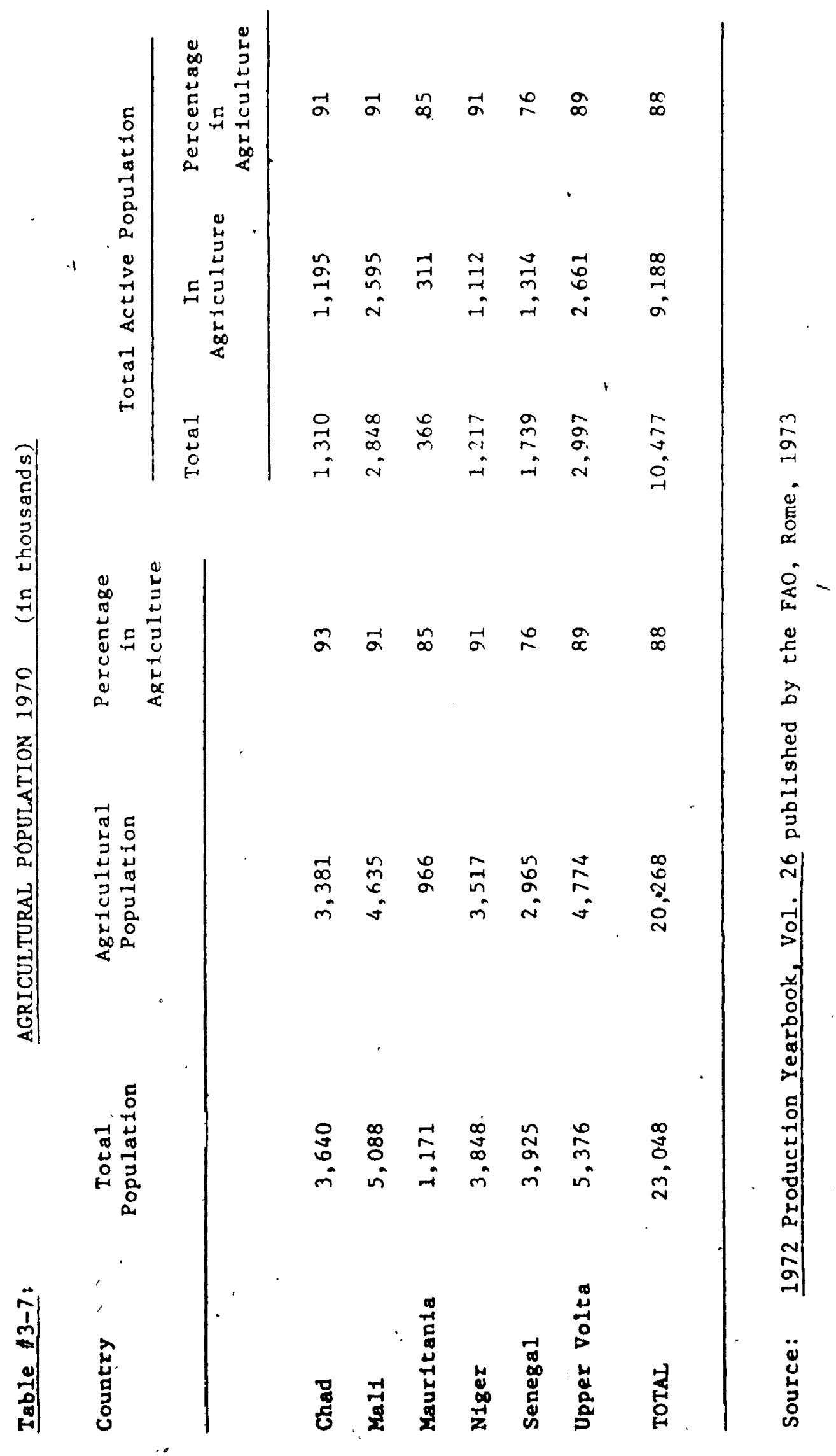


and livestock production.

Among the indicators which trace the relative progress of the economy are those for manufacturing and agriculture. From 1960 to 1970 , the average growth rate of agricultural production in the Sahel region was only $1 \%$ annually. This compares very unfavourably with the $2.8 \%$ achleved in the same period by the remainder of the developing nations. However, manufacturing grew at an annual rate of $5.0 \%$, which can be considered to be quite favourable in relation to the other developing countries which show a growth rate of $7.1 \%$ (see Table $3-6$ ).

A more careful scrutiny of the data, such as is presented in Table $3-8$, will show what progress has been made in agriculture. Between 1963 and 1970 the average annual growth rate of food production in the Sahel countries was a mere $0.4 \pi$, or less than half the rate of increase in agriculture as a whole. This would seem to indicate a stronger emphasis on cash crops for exports as opposed to food crops for domestic consumption. This situation was reversed between 1968 and 1971 when the growth rate of food production rose to $1.9 \%$ compared to the rate for agriculture of $1.7 \%$. There was a subsequent increase again between 1970 and 1972 but even that did not prove enough to off set the increased demand of food luports during the same year (see Table 3-11). 
0

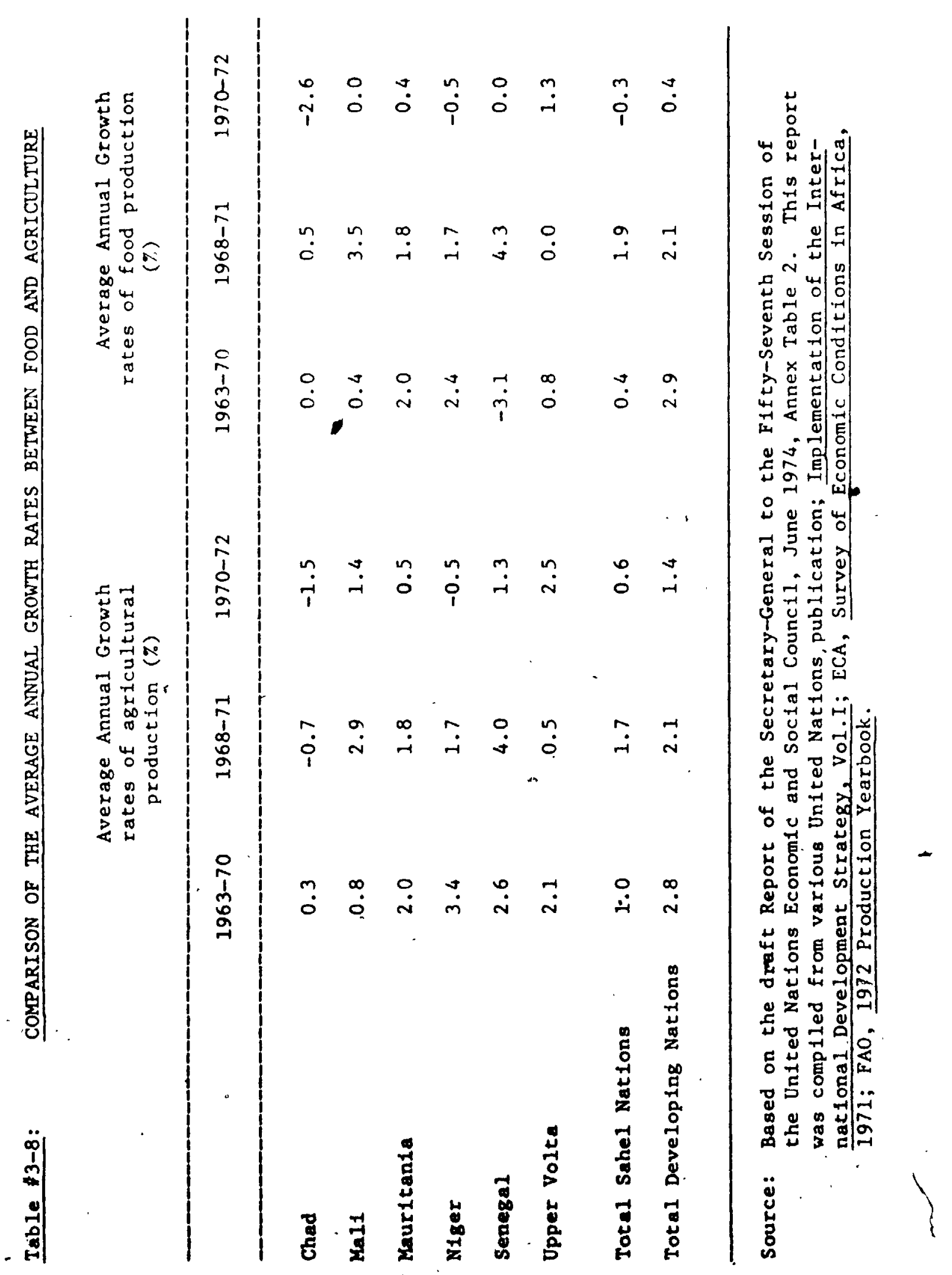





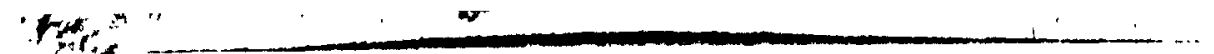

64.

0

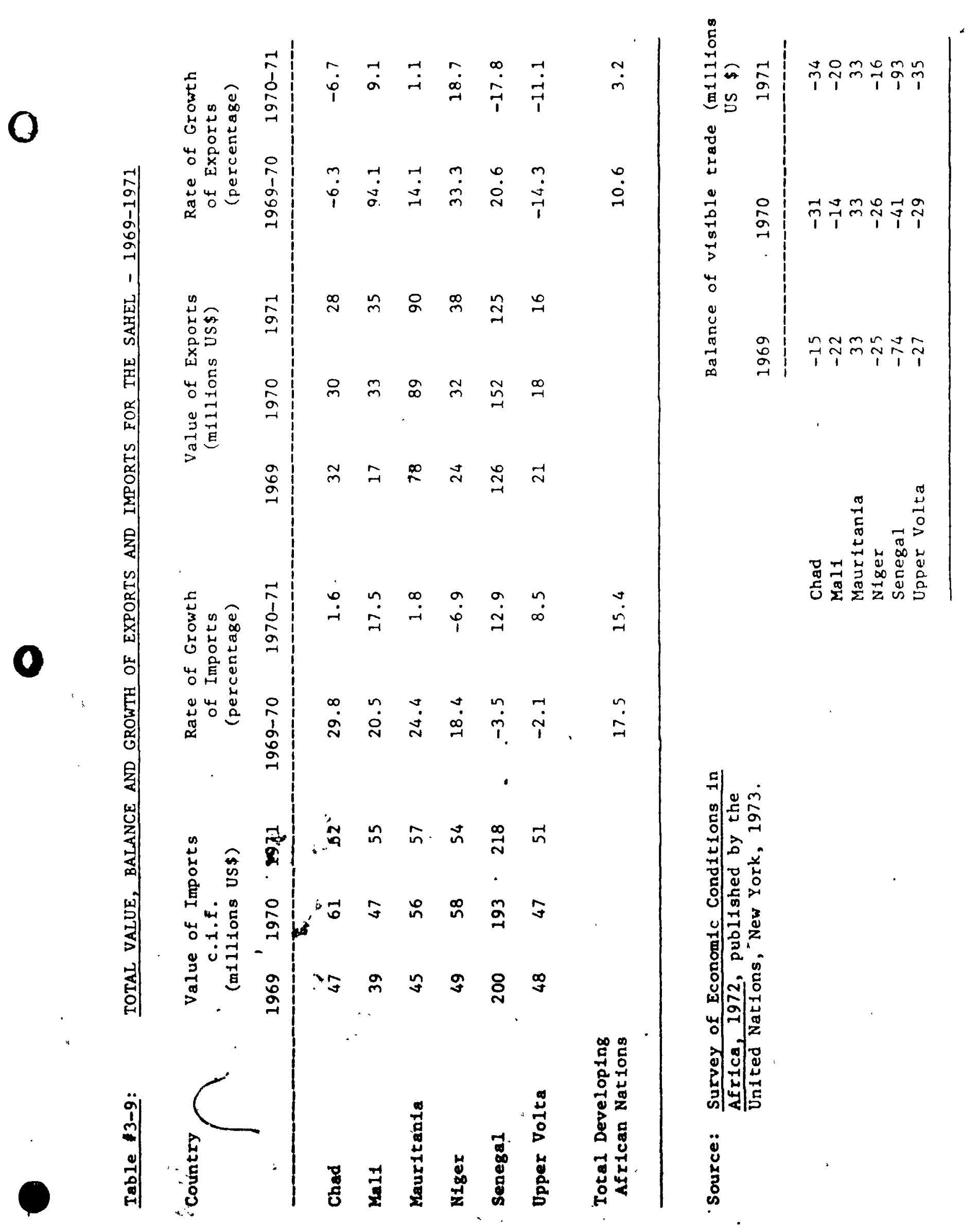


$\mathrm{O}$

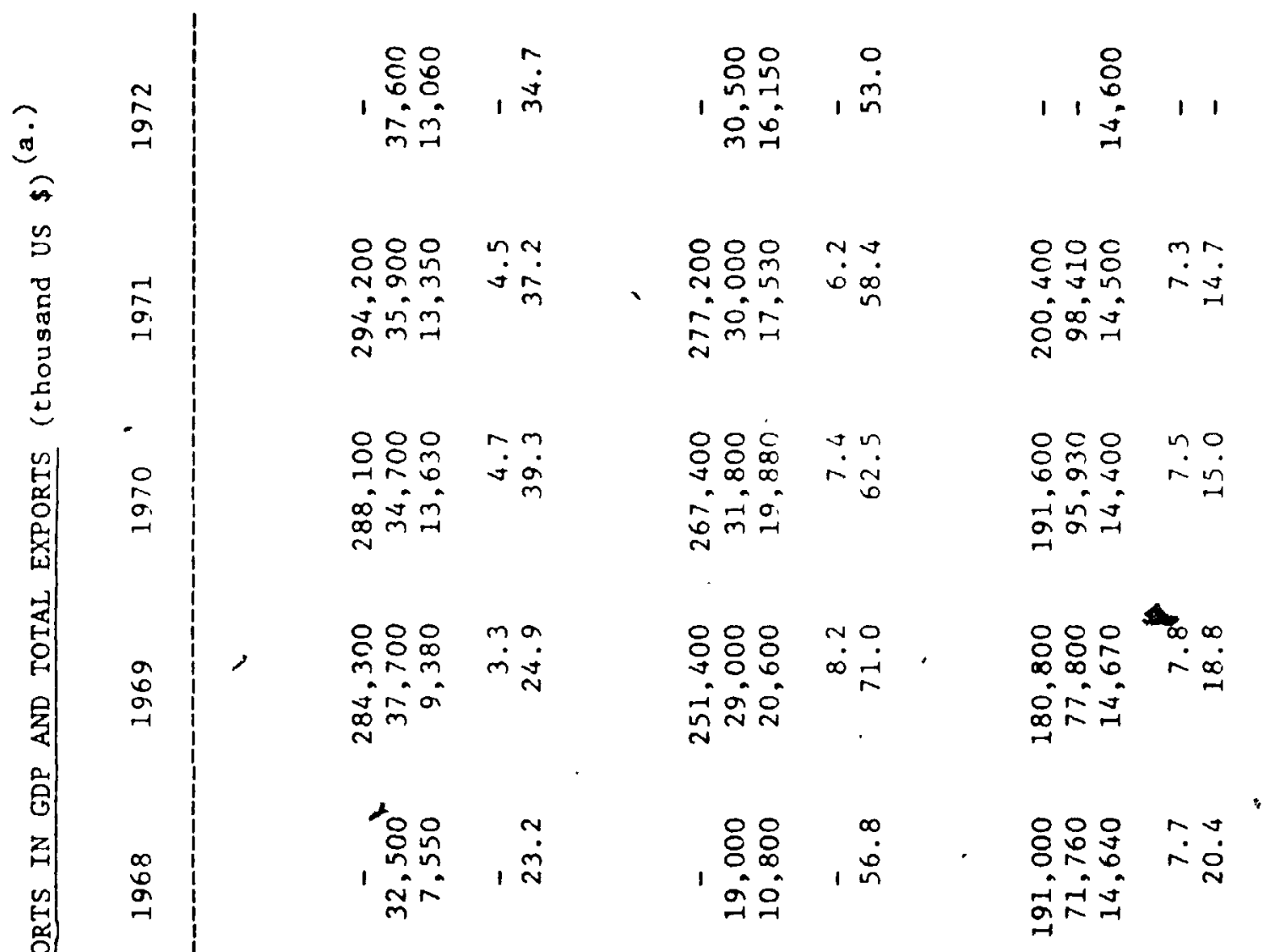

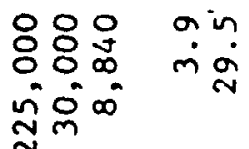

응요 in

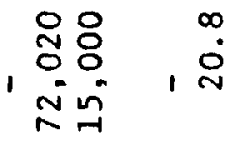
, 8 昌

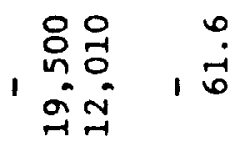

, ํㅠㅁㅇㅛ

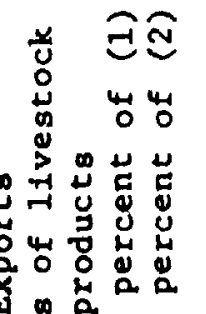

ํํำ 苏出出

究思艺芹

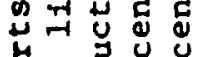

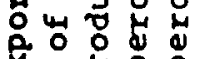

व̈

合

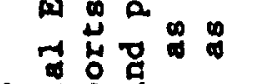

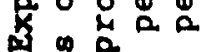

它葆各

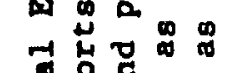

疍

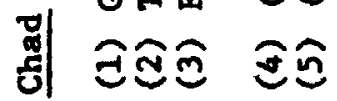

뫼

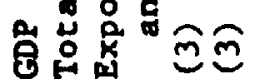

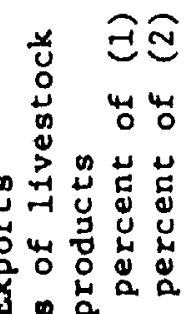
员员怘吕

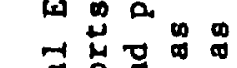

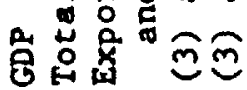

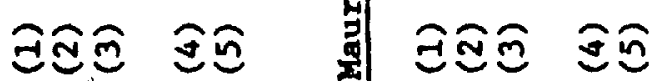




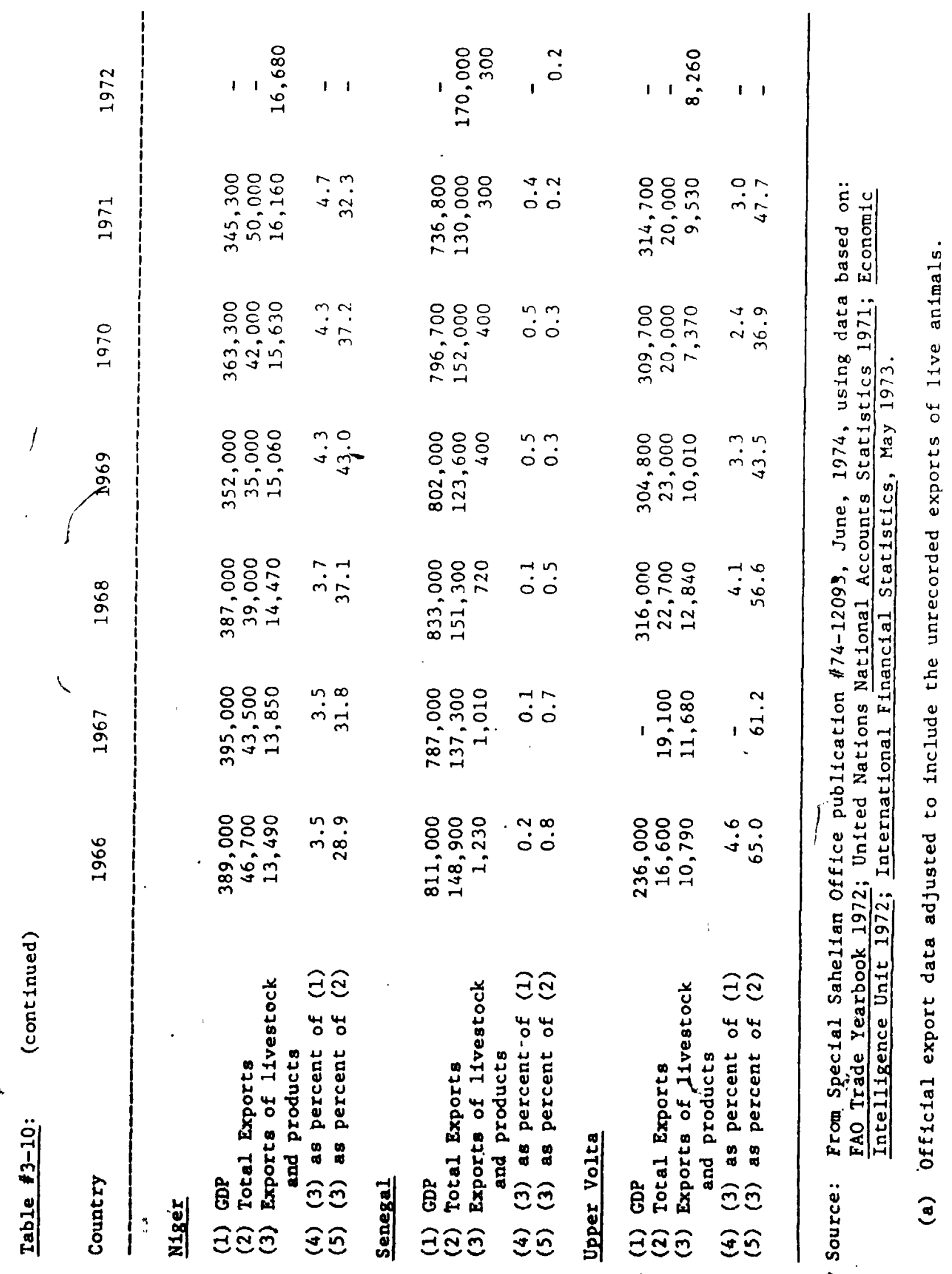


Obviously, with this dependence of the Sahel countries upon agriculture and allied exports, the present drought situation had to be catastrophic. However, such exports are not only subject to the climatic vagaries, they are very vulnerable to external demand, international trade prices, and any domestic policies which can have an impact on the level of output. Thus, the primary producers of the Sahel only have marginal control over the conditions which affect their product development. The major factors, which can behave in a most erratic manner, are entirely beyond the control of the primary producers. It should also be mentioned that this overdependence on cash crops and unprocessed exports does not provide the necessary feed-back into the economy and has not generated economis growth. The exports of meat could do much to aid the needed feed-back and is considered to have a vast potential in this regard, provided herds are reconstituted, livestock health is improved, meat processing practices are developed and distribution infrastructure strengthened.

Traditionally one thinks of the importing countries as having control over the amount of thefr imports. Unfortunately, this is not the case in the Sahel region since a large percentage - of the Increased impor $\{s$ have been food requirentents (see Table (3-11). This increased importation of food products may be explained in part by this severe drought situation, however, agricultural planning way also be partily responsible since 
ים 
Table 3-8 1ndicates a low average annual growth rate for food products when compared to general agricultural production.

d. Savings, Investments and A1d: The inflows of foreign aid $\therefore$

to the Sahel countries has been larger on a per capita basis

than for most of the less developed nations (see Table 3-12).

Between 1965 and 1971 this amounted to almost $\$ 7$ per head compared to $\$ 4.80$ for the other countries. But, as large as this figure may be, it still cannot be considered adequate. This external aid is very badly needed by the Sahel countries, not only to of set the balance of payments, but to fill the savings/1nvestment gap. It is the low level of the per capita income which means a very low ratio of savings/GDP, thereby Iimiting the domestic resources for captal formation. Only Mauritania may be considered to have an adequate savings/income ratio. However, a large share of the savings, since it comes mainly from mining, is transferred abroad and is thus not avallable for domestic investment.

The low rate of domestic savings is directly related to the low per captita fncome and thus any developmental investment funds must come primarily from external sources. This was already the case before the drought situation, although in the pre-drought perfod it cannot be clearly stated that the ald Inflows were necessar1ly compatible with the needs of 


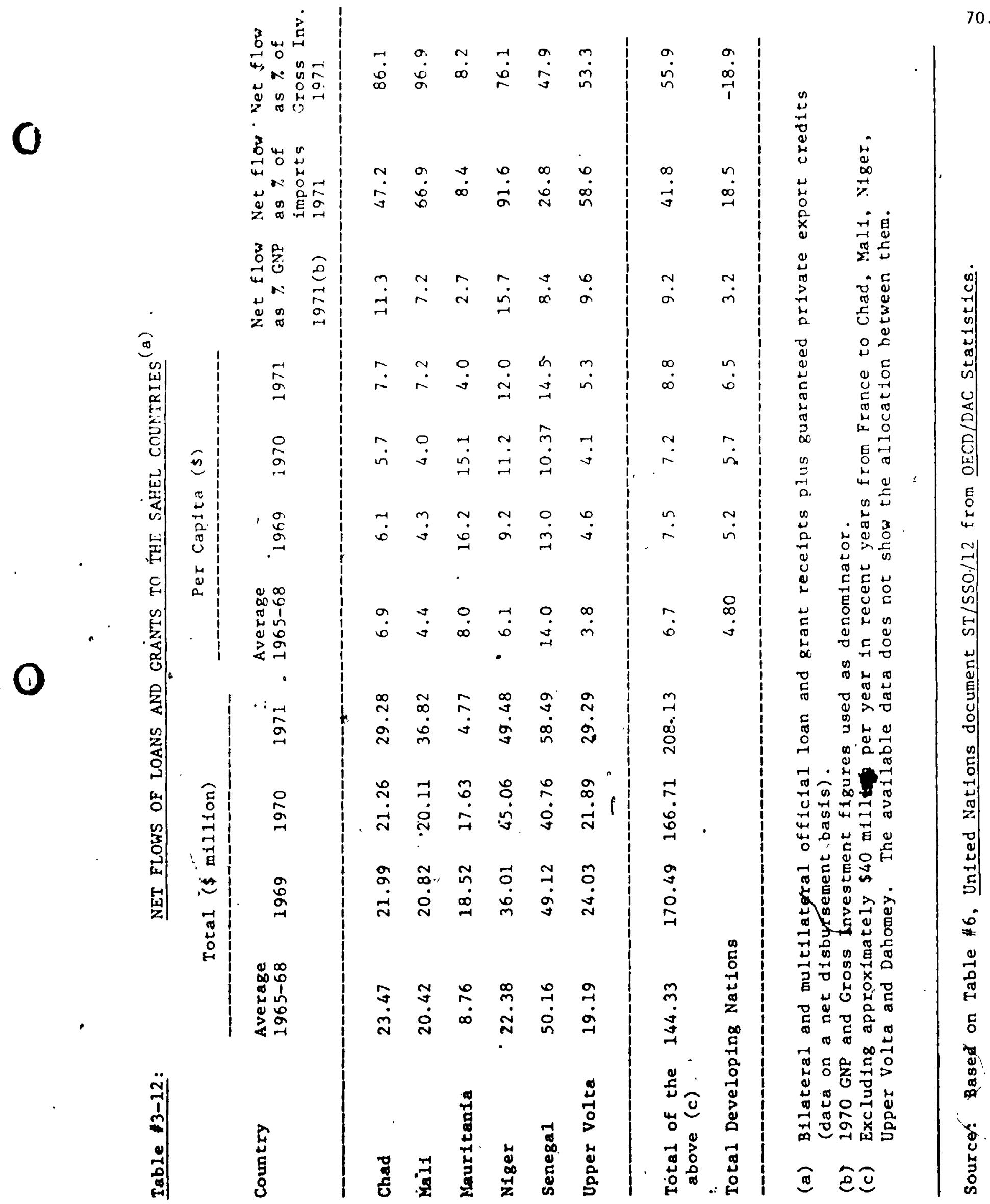


the countries. Much foreign ald pre-1970 was bilateral and uncoordinated. Since the drought became World knuwledge in early $1973^{7}$ the many billions of dollars which it is expected will be invested in the Sahel reglon will likely be very closély coordinated through the Spectal Sahetian office (SSO) of the United Nations (UN). in New York. 8 .

Besides the heavy dependency of the Sahel countries on financial foreign aid, technical aid is also very important. While technical aid consists of loans, plant and equipment, the technical assistance of outside experts is also very a crucial since the present pool of skilled Africans is very smad 1.

e. Sector and Reglonal Integration:- The integration of the sectors within each of the Sahel countries and the regional Integration of all six Sahel nations has ben included at the end of this chapter because it 1 s considered to be the locking key for the future of the entire Sahel, a point which w11 be domonstrated in the 1ivestock strategy of chapters VIII through $X$ inclusive.

The various economic sectors of the Sahel countries suffer from a lack of close Internal and external ties. This ts even true between relatively close sectors such as agriculture, itrestock and water. Relationships between the sedentary agriculturalists and the nomadic herdomen have historically. tended to emphastze Indepandencie at the expense of complementary 
exchange and co-operative use of mutually advantageous resource capability.

The primary sector, particularly mining in Mauritania, is a classic example of the non-integration of a sector, which perpetuates an export enclave that does not produce a significant feed-back into the economy.

This lack of integration, both internally and regionally, of the economic infrastructure, transportaţion in particular, 1

- has led"to some large projects which are not economically feasible, thus diverting resources from a more efficient use.

To overcome the basic problems created by the lack of sector and regional integration, greater emphasis would have to be placed on regional projects of an economically-viable and highly productive natule, combined with a harmonisation of policies that promote, with both an internal and an external - orientation, greater inter-dependence of resource use.

\section{SUMMARY}

Clearly, it has been shown fust how vulnerable the economles of the Sahel countrles are when exports and Imports were briefly examined. In this chapter, it has been demongrated how the primary, production sectior of agriculture and livestock are nartowly and directly dependent on favourable climatic conditions. Although irrigation is practiced to \& limited extent, agricultural 
and livestock production are obviously constrained by the availabllity of adequate rainfall in both time and place.

The countries have been shown to be at a distinct disadvantage concerning the1r highly unbalanced fmport-export patterns. Imports, particularly of food, but also of petroleum and machinery, when combined with madequate and undiversified exports clearly clarify the balance of payments deficit show in Table 13-9.

- On aid, it should be mentioned that though much ald badly needed, as was suggested, it is the perpetuation of the present forms of aid which lead to discontent, and the continuation of the dominance of economic enclaves with the resultant fallure of the feed-back mechanism to provide the necessary technical skills for production within the economy. The financing of the Livestock Plan (chapter IX) set forth a method of ald, both financial and technical, which it is belleved would be more, able to the Sahel countries than the means heretofor used. Before closing this chapter, where the concern has been with the development of a goegraphic and economic picture of the "respective economies of the Sahel countria, it was necessary to dwell briefly on sector and regional integration. This notion of integration is the key factor in the Livestock Plan which will be proposed for the recovery and future development of beef cattle in the Sahel. . 
Q

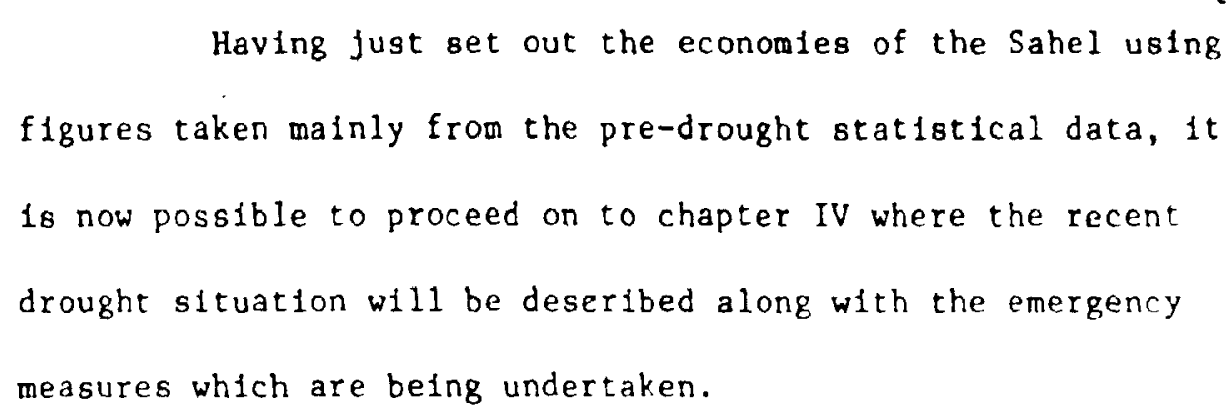




\section{FOOTNOTES}

1. Labour Force Projections - Africa. Published by the International Labour Organisation, Geneva, 1971. Taken from "Population Growth 1970-1980" published by the United Nations, ST/SSO/21/

2. See "Economic Background" section of this chapter.

3. The Harmattan consists of a strong southward surge of fresh, dry, northerly alr. Since the wind has had a long trajectory over the Sahara, it is very dry, cool by night and warm by day, and is heavily laden with dust. Thus, a dense and widespread haze is characteristic of Harmattan weather, a condition which may persist for several days.

4. "Water Management" published by the United Nations, ST/SSO/11, $6 /$ Nov/1973. p.3.

5. "Public Health Sector Analysis" - World Health Organdsation, published by the United Nations, ST/SSO/15, 4/Dec/1973. p.2.

'6. "Livestock - A Suryey" published by the United Nations, ST/SSO/10, 9/Nov/1973: p.3.

7. The New York Times, 13/May/1973 published the FAO appeal for drought rellef for the Sahel countries.

8. Resolution 1759 (LIV) adopted by the United Nations Economic and Soctal Counc1l at the 1857th Plenary Meeting, 18/May/1973. 


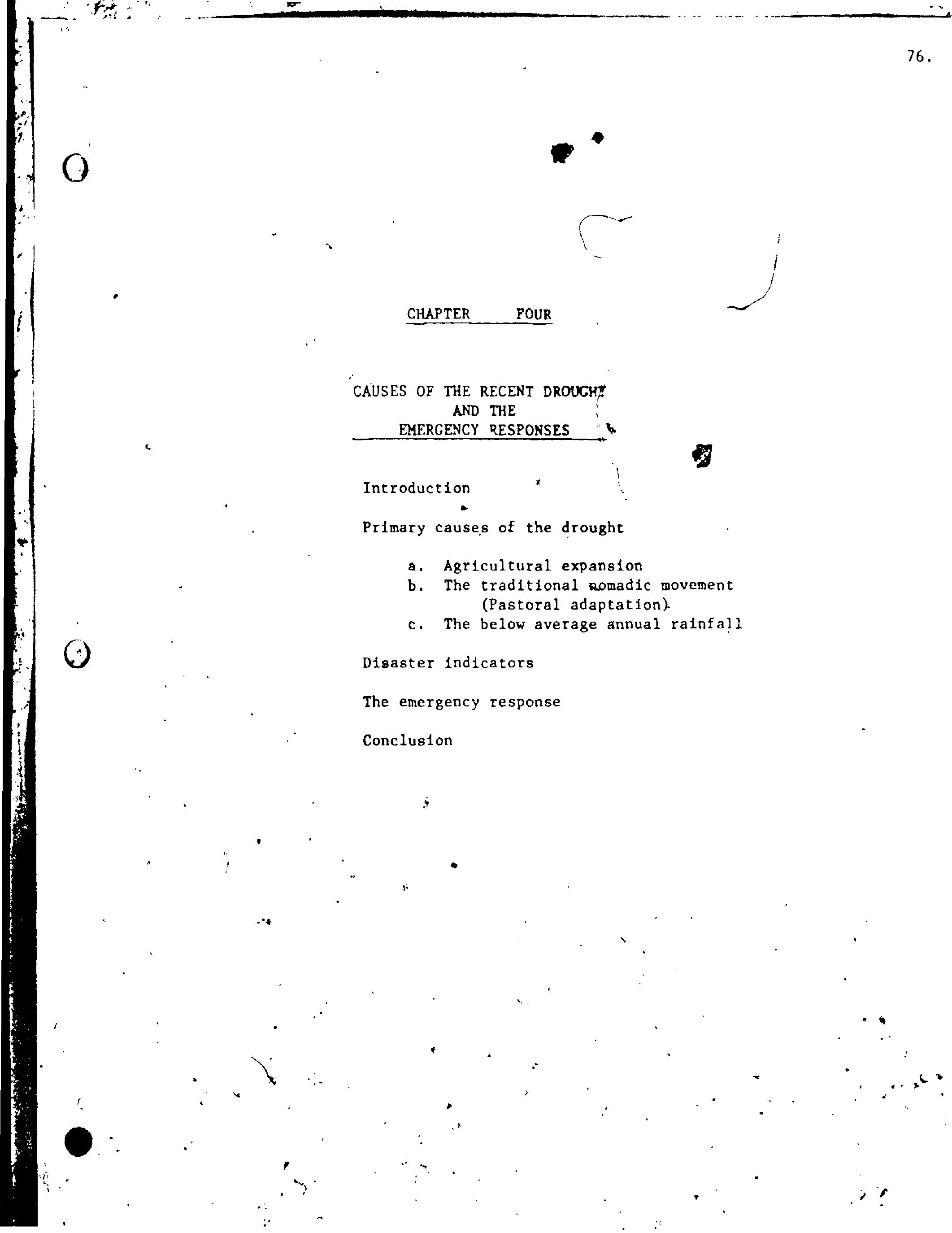




\section{INTRODUCTION}

Chapter III was concerned with the pre-drought economic development of the Sahel countries whlle, at the same time, detalling the statistical data which reflects the ecopomic crisis during the years of the recent drought. The Press of the western countries has, since 1972, done much to highlight this economid catastrophe which assalled the Sahel region, but the Press has alşo tended to blame the drought as being the 'cause'. The aim of this chapter is to allay this simplified notion of 'one cause (drought) leading to one result (an economic crisis)'. It will be shown that really, both the drought and the economic troubles are 'results' of a major drama whlch began, In the Sahel, over a: hundred years ago. A continuing drame which really had its roots in the era of early colonialism and the resulting agricultural development policies of recent years.

At the end of chapter III, mention was made about "Sector and Regional Integration". "This chapter, having la1d bare the root causes of the present economic troubles, will clearly substantiate the need, in future, for such integration. 
Subsequently, this chapter examines the early warnings given concerning the drought emergency and also the World response to these warnings, thereby providing some understanding for the heavy Involvement of the United Nations (UN) and the Food and Agricultural Organisation (FAO).

In summary, while chapter III provided the economic back-ground data which the Plan of chapter VIII seeks to improve, this chapter provides the physical back-drop for that same plan, "A P1an for the recovery and long-term development of beef cattle in the Sahel".

\section{PRIMARY CAUEES OF THE DROUGHT}

The fact of the current drought in the Sahel has been well known for the last two years, but what is not so well known 1s, when the present drought really started and its true magnitude.

It is suggested that there are really three reasons which have contributed to the present inflicted economical disaster:

a. Agricultural expansion

b. The traditional nomadic movement

c. The below average annual rainfall

While ttems (a) and (b) above have been considerably affected by the lack of rainfall, it is felt that the existing economic fallure really had its roots in the more recent history of the Sahel region. 
It may also be suggested that the economic crisis of today would eventually have occurred anyway, even without the added effects of a prolonged drought.

This last statement may be considered as rather a harsh indictment of the economic management of the Sahel countries. But a brief explanation about "Agricultural expansion" and the "traditional nomadic movement" will show proof of the statement's validity.

a. Agricultural Expansion: It is really the agricultural expansion which has probably had more to do with the present economic plight than has the recent drought. The rationale, for this suggestion may be found in the roots of the colonial history: 1 ,

"The Colonists (French), who exploited certain parts of the'sarea under consideration for two centuries, never worried very much about the future of the lands they occupied and the peoples

, living there..."

Like many Colonists, during the era of European expansion, particularly whare the climate was considered unhealthy (West Africa being called "The whiteman's grave"), it was the 'biggest profits in the shortest time' attitude. 'This meant extensive cash crops for export such as cotton and groundnuts with almost a total disregard for the domestic needs of good cultivation. 2 . Under this pattern of extensive farming, increased agricultural, output was derived from the simple expedient of 
land clearance with the additional land being placed under cultivation. It appears that very little research was undertaken directly for the Sahel region with a view to increasing the yield per acre. ${ }^{3}$. The process of ever increasing land clearance meant that more and more trees were being destroyed, thereby leading to the drying-up and eventually the present erosion of the soll.

Besides the European colonists and their cash crop production, there was a communal colonisation from off-shoots or segments of villages. In this instance, the agricultural expansion is a colonisation resulting from population pressures with an increase in cash cropping. The latter increase being of ten brought about by reducing the fallow pertod.

Interestingly enough, this '1and-clearance come farmexpansion' program mostly tended to be in a northerly direction. To expand south was not a practical Idea due to the increased humidity and the accompanying higher incidence of diseases affecting both man and livestock. 4 .

The spread of the farms northward may be considered as one side of a 'land squeeze'. While the other side of the squeeze clearly may be thought of as the work of the various health programmes and the medical missionaries. The health programmes , being designed to reduce the mortality rate and generally 
Improve the health of the people, thereby contributing to an Increased rural population, and an expanding demand for food production. Table $\#-8$ and $\# 3-9$, would seem to confirm that even in very recent years, too much of the expanded agricultural land was devoted to cash crops and too l1ttle to the Increasing demands for domestic food production.

b. The Traditional Nomadic Movement (Pastoral Adaptation): It is the cycle of annual rains followed by a long dry period which led to the pattern of pastoral nomadism, a classic example of how malapted to his environment: 5 .

"Pastoral nomadis $m$ is a rationale response to a moisture deficient, fragile environmept."

Becausé the region in which they live is characterised by low water avallability, seasonal drought (the wet period being only two months a year - chapter III), and widely scattered seasonal forage resources, the nomads make use of resources which are beyond the reach of the sedentary agricultural population. Under the traditional system of movement developed by the nomads, the herdsmen would alternatively concentrate ground the 'dry season' wells ${ }^{6}$ or some other permenente resource, or move to Bome other partsiwithin their tribal territory. During the latter part of the dry season, usually January or February, the nomads would move their herds and flocks southwrd or towards the rivers. By that time of the year the northern grassland 
reglons have become very sparse due to lack of molsture. However, during the ralny season, July to September, the nomads then return north.

While this pastoral adaptation of nomadic movement is capable of dealing with most of the climatic fluctuations around the mean condition, extreme events such as the present prolonged drought are always devastating. Inder these extreme conditions, which have occurred throughout the climatic history of the Sahe1, the nomads contynue to adapt by an adjustment of time in the transhumance. It was earlier mentioned that the southward movement usually takes place in January and

- February, but during the periods of extreme drought the nomads made further adaptation. The current examplebbeing the start of their move south as early as October during the 1972-1273 drought period, as happẹned in Mal1. By the same token, the northerly return, which normally occurs during the wet season, virtually did not take place at all in 1973 or 1974 .

This present fallure to return may be partly explained by the fact that the northern grazing lands, where the nomads usually directed their herds for 'salt treatment', ' had dried up.

The cessation of the northward return movement has caused. an unusually large concentration of animals in the southern Sahelian and northern Sudanian zones during the past few years. 
It should be noted that now these animals are concentrated on less land than was the case during previous extended droughts, since much land has been absorbed for cash crop and subsistence cultivation (see previous section "Agricult-

-ural Expansion"). In the face of the present drought, purportedly the worst in sixty years, 10 and with less pastureland avallable than was heretofore the case, millions of antmals and people have died and/or faced starvation. The obvious result of the increas livestock concentration on less land means a serious overgrazing situation, a condition which has caused the large herds to further destroy ail the trees in their search for food. Hence, more land is being

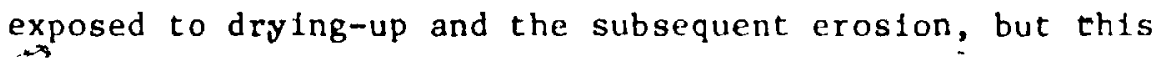
time from cattle.

c. The Below Average Annual Rainfall: 'The year 1972 marked the first time in sixty years that the big rivers, namely the Senegal, Niger and Charl falled to flood their banks. In chapter III, using Table 3-3 and Chart \#3-1, it was shown fust how reduced these water levels have become, a situation further clarified by May $\$ 3$ which showed the percentage of normal rainfall received in 1972 and 1973. However, it should be mentioned that the recent.period of below average rainfall - actually began in 1966 for some areas in the Sahe1. ${ }^{2}$. During the f1rst few years the effects were not too not 1ceable because the couptries were able to continue most economic activities

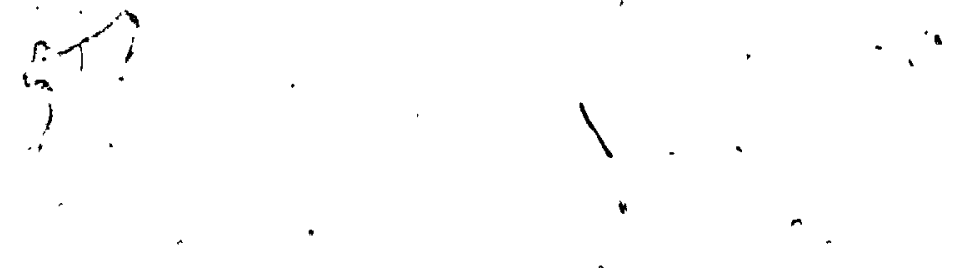


- using the tradtional reserve supplies of water. 13. Unfortunately, with the continuation of the declining anqual rainfall, the reserve water resources were not being replenished as would be the case under conditions of normal rains.

At the beginning of this chapter it was suggested that, "...the economic crisis of today would have eventually occurred anyway, even without the added effects of a prolonged drought.". Having briefly explained "Agricultural Expansion" and the "Trad1tional Nomadic Movement", 1t would seem clear that even in the absence of normal rainfall, these two factors appeared to form a two-pronged potential for soil erosion. 14 . Thus, the Sahel countries would eventually have suffered some degree of economic chaos.

The converse is also true however, in that, given adequate management of the economy concerning cash crop development and farm expansion, the present drought effects would not have been so far reaching in terms of human lives and the loss of livestock. 15 .

Having explored the primary causes of the current economic state of the Sahel nations, it is now possible to proceed to, the detalling of the "Disaster Indicators" and the subsequent World response to the drought crisis.

\section{DISASTER INDICATORS}

In early 1973, Belg1an Senator R. Scheyven conditeted a 


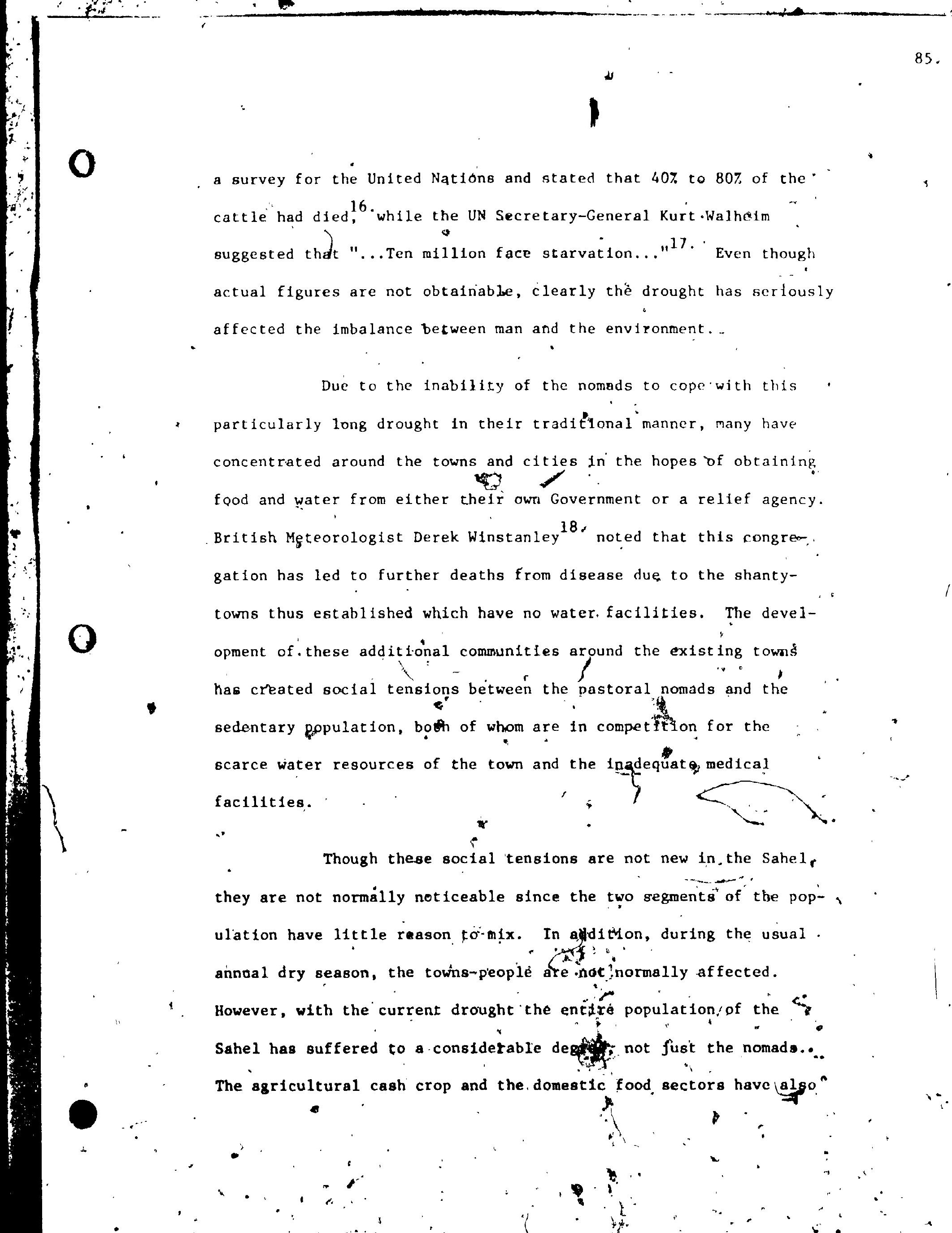


been severely affected. The rains which have occurred in $1971,19$. 1972 and $1973^{20}$. have been both too $11 t t l e$, too late, and maldistributed. The 1974 rains seem to have been a 11ttle closer to the annual norm in a few areas.

Despite the continued fallures of the rains since 1968, the Sahel economies have been struggling to malntain some semblance of trade in livestock since this has always been a major segment of their exports (see Table $3-10$, chapter III). But both the quantity and the quality of the cattle for export has dwindled. Most animals going to market in recent years have been tough and boney from their hard struggle to qurvive. This in turn has led to reduced weight and the consequently lower prices. 21 . It should also be noted that all grain reserves and seed stocks have long since vanished, these normally being only designed to cover a one-year shortage.

Th1s trend of economic decline is also reflected in the small secondary processing Industries which are dependent upon agricultural products as the raw Inputs for thetr operations. Thus, some of the plants have had to close thelr doors causing further unemployment in the urban areas. While the industrial plants of the Sahel may not be considered to be a major segment of the econony, and hence the unemploysent caused would seem to have only a - arginal effect, It nonethelese, leade to a further exacerbation of the econony plight. 
So much for the actual consequences of the drought and the devastating effect it has obviously had on the all too fragile economies of the $81 x$ Sahel countries. But before an attempt can be made to develop a Plan for the future of the beef cattle Industry, it is helpful to see what the emergency response has been in general.

\section{THE EMERGENCY RESPONSE}

By September 1972, the worsening situation in the Sahel had reached disastrous proportions ${ }^{23}$ causing the FAO and the World Food Programe (WPP) to signal an acute emergency for West Africa because of the endemic nature of the drought. The exceptionally poor harvests of 1972 prompted the Governments of the region to intensify their foint efforts to meet the growing crisis. However, their efforts were in dire need of external help and thus the FAO recelved a request for emergency assistance from the Intefstate Authority of Mali, N1ger and Upper Volta. 24. It was this request which led to the UN/UNDP/FAO filed task force 25 to provide Immediate assistance to the livestock population. In response to a the task force report ${ }^{26}$. and a subsequent resolution adopted by the Untted Nàtione Bconomic and Social Counç11 ${ }^{27}$ (ECOSOC), vast quantities of ald were promised and Indeed forthcoming from the many ald-giving egenctes throughout the World.

In Februngy 1973, the Director-General of the PAO appraved 
the highest single contribution of food aid in the history of the WFP, Inftially $\$ 7.7$ million. The amount was raised to $\$ 9.5 \mathrm{mill1}$ ion by the end of $1973^{29}$.

On May 10th, 1973, the FAO Director-General Boerma appealed for additional financlal assistance from the international community to the tune of $\$ 15$ million. $3^{30}$. This sum was forthcoming from the UN in July 1973 with the requirement being estimated at $\$ 5.5$ million to be allocated for animal feed and vaccination, $\$ 4$ millions for seed and $\$ 5.5$ million for well-digging equipment.

To coordinate this massive relief operation, the FAO Director-General, on May 20th, 1973, established a special office In Rome to be known as the office of Sahelian Rellef Operations (OSRO). 31. At the same time the United Nations Secretary-General K. Waldheim established a Spectal Sahelian office (SSO) under the office of the United Nations Under-Secretary-General for Political and General Assembly Affabrs (PGAA Bradford Morse. This UN Office was to be responsible for the medium and long-term assistance activities in the Sahel region. The sSo was subsequently confirmed by the Ministers of the affected Nations when they met in Geneva, $28 / 29$ th June, $19733^{32}$. The reciplent nations obviously were making good thelr pledge to work together as was decided at Ouagadougou In the 26/27th March meeting when they established a Perwanent Inter-State Comittee on Drought Control. 33. 
While the emergency response has brought millions of dollars in 1mmediate rellef programmes to the drought strickened countrles, such a system of 'ad hoc' expenditure can provide no lasting recovery or future development planning. Clearly, it has now become the responsibility of the SSO in New York to provide a development plan for the long-term rebullding of the devastated Sahelian economies.

In line with the new policy of co-ordination of all ald, so that the results can be more beneficial, the WFP has also modifled their pollcy as regards the Sahel. While in previous years food ald through the WFP has been provided as emergency rellef, this assistance from 1974 on will be provided almost exclusively under "Food for Work" projects." This idea is to provide incentIves to the population so that they w11 become involved in the drought rehabilitation programmes. It 18 also a means of obtaining the much needed manual assistance for the various profects which will be undertaken by the ald agenctes with regard to the construction of wells, irrigation projects, re-forestration and soll conservation, rood malntenance and community development.

\section{CONCLUSION}

Having eatablished the general back-ground to the Sahel countrles and the eaergency weasures which have been undertaken, It 18 now posesble to proceed to the analyes of the livestoch 

1. Michel C. Baumer, Towards a Strategy for Development in the Sahellan and Sudano-Saharan Zones, publlshed by the United NatIons, ST/SSO/Rev. 1, 30/0ct/1973. p.3.

2. Th1s point was confirmed as belng the case even durfing the $1960^{\prime} 8$ as was indicated by Table $3-8$, chapter III. The table showed that between 1963 and 1970 the average annual growth rate for food production was only $0.4 \pi$, while general agricultural production had a growth rate of $1.0 x$.

3. While much research has been undertaken by the French and British, it has been carried out mainly in the coastal countries of Ghana, Nigerla, Ivory Coast and Dahomey, having little direct application to the devastated Sahel region. It should be further added, that most of the research 18 being malntained in Paris, London and Rome, hence the author has not been able to read very much of this research directly, but has had to be guided by references made to it through other sources available in Ottawa.

4. The most troublesome diseases being the cattle allments of rinderpest and prypanasomiasis. Humans are affected by onchocerclasts (rlver blindness).

5. Dougles L. Johnson, The Response of Pastoral Nomads to Drought in the absence of out alde intervent. on, p.3.

An unpublished paper on file in the United Nations SSO, written in 1972 .

6. "Dry season wells" will be more fuliy explained in Chapter VI of this paper.

7. Official meteorological data only goes back thirty years, but explorets accounts and the colonial adaintatration reports. from 1829, confirm the cyclical nature of extrete drought on approximately a twelve year cycle.

8. A key area being the Wan-Irhazer regibin west of Agades, Niger, where the marshy area is rich with saline-resistant annual. grasees.

9. Salt 1o an Important dlet factor for livestock as is the case. for people. Thus, the nomads ensure th their cattle receive an abnual addition to thatr diet. Salt-hcke are provided in nost cattle ranches or feed-lots. 
10. The last prolonged drought in West Africa began in 1915, lasting for five years unt1l 1920 .

11. An approach to recovery and rehabllitation of the SudanoSahellan region, draft report of the Special Sahelian. Office of the United Nations, 74-12093, 1974. p.5.

12. Michel C. Baumer, op.c1t., P.2

13. "Reserve supplies of water" refers to the permanent wells and reservolrs throughout the region. This will be more fully explained in chapter VI of this paper.

14. An exact repeat of the United 'States 'dust-howl' in the mid-west during the $1930^{\prime} \mathrm{s}$.

15. Detalls concerning the $108 s$ of 11 fe and livestock are explalned under the next section, "Disaster Indicators".

16. The New Jork Times, 21/May/1973.

17. Ib1d., 9/Jun/1973.

18. Ib1d., $9 / \mathrm{Jun} / 1973$.

19. The Washington Post, 15/Nov/1971 pertaining to Upper Volta.

20. The New York Times, 12/Aug/1973 concerning the total Sahel area.

21. World Animal Review, No. 8, publishedisy the FAO reports of price declines from $\$ 120$ per head to $\$ 20$ or less in many areas.

22. The New York Times, 21/May/1973.

23. Report by the Director-General of the FAO, Rome, E/5372, 7/Jul/1973. p.3.

24. Resolution adopted by the Ministers of the Sahelian countries at their weeting in Ouagadougou, 26/27 March 1973.

25. United Nations Developwent Programe (UNDP).

26. Report of the alseton of Mesers. Scheyven, Mensah and Reynt fene; 7/20th Apr11, 1973. Inter-Department Working Group on Sahelian probleme WS/D 8795, 4/May/1973.

27. Resolution adoption reported in WN publication $1 / 9092,19 / J u 1 / 1973$. 
28. Drought Rellef Plans for S1x West African Nations Mapped at FAO Headquarters, press release $\mathrm{PAO} / 2390,27 / \mathrm{Feb} / 1973$.

29. WFP Announces Food A1d to help rehab1litate Sahelian Drought Areas, press release FAO/2473, 21/Feb/1973.

30. "FAO Appeals for emergency rellef needs", The New York Times, $13 /$ May/1973.

31. Secretary-General names the Food and Agricultural Organisation as the focal point for aid, press release, $S-G / 1773$ and FAO/2403 both dated 25/May/1973.

32. Meeting for co-ordination of the Sudano-Sahellan Medium and Long-term programme, In Geheva 28/29th Jun/1973. Attended by representatives of all ald-giving agencies and the Minlaters of the Sahel countries.

33. Although pot present at the 26/27th March Meeting, Chad was an original member of the Committee.

34. Report of the Secretary-General to the 57th Sesston of the ECOSOC, June, 1974. p.17. 


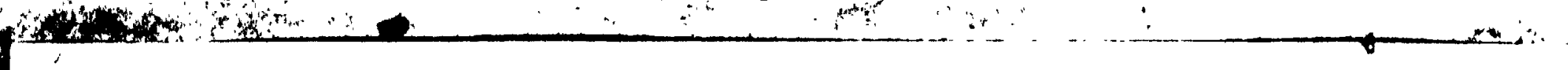

94.

CHAPTER FIVE

WORLD TRADE IN BEFF AND

THE

POTENTIAL FOR THE SAHEL NATIONS.

Introduction

Livestock in World trade

a. World demand for beef

b. World supply of beef

c. Beef Trade Barrlers

(1) Health Barriers

(11) Economic trade barriers

(111) Continutty of Supply

Recent developments in beef trade stragegy

The future for beef

Problems facing cattle development in the Sahel

Summary

1 

0

0

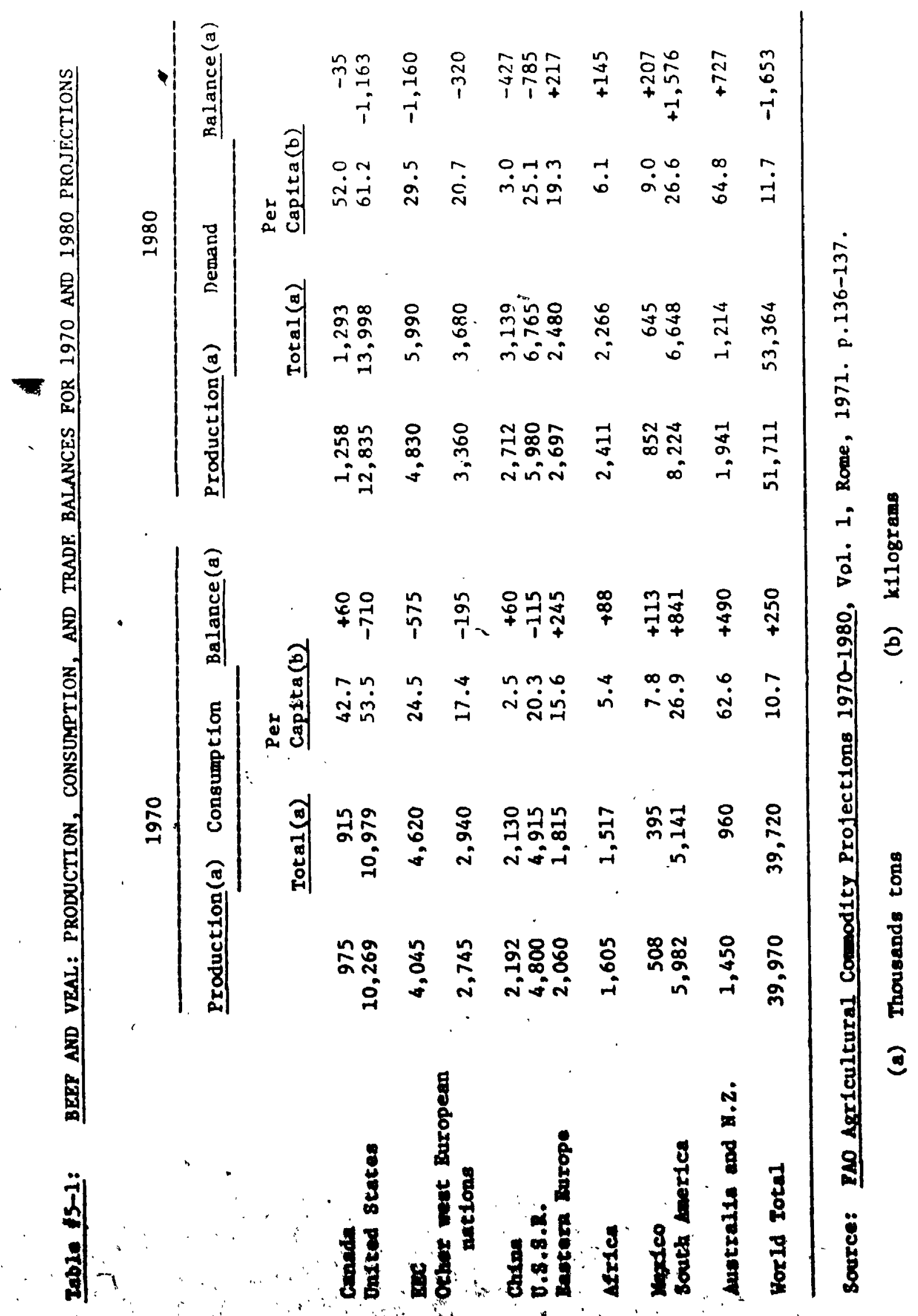


would seem to be mainly South African beef, since the PAO suggests that the surplus of beef from East and Central Africa would be exports to West Africa, thereby fllling the profected import needs of that region ${ }^{1 .}(318,000$ metric tons by 1985). Chapter VIII, "The Plan", w1ll consider both the European and the West African markets for beef since, in the future, it is anticlpated that there w1ll be free export of beef from the Sahel.

However, at present, free export of beef from the Sahel is not possible, even gtren-that the Sahel presently had a beef surplus, which 1 toes not. There are several barriers to fręe trade which will also be considered in this chapter, because an understanding of these barriers, particularly those pertaining $\therefore$ to health and economics, are important considerations when the Plan is proposed later in this paper.

Once the World beef situation has been understood then It will be possible to look more closely at the problems facing beef cattle development in the Sahel economies.

Having thus examined World Trade in beef and the stockralsing problems in the Sahel, the two opening questions will then have been answered. Therefore, the way will then be cleared for an examination of more fundamental teems concerning the development of 
a beef cattle industry in the sahei region.

\section{LIVESTOCK IN WORLD TRADE}

Meat, in the World at large, would gem to be produced principally for domestic consumption aince only about $5 \pi$ of all carcass meat enters World Träe? 2 . Of the total World trade, while agricultural production accounte for $25 \%^{3}$. meat and 11vestock make up only $1.97 \%^{4}$.

Probably the most Important feature of World trade which should noted, is that meat and livestock prices have Increased substantially between 1967 and 1972.' Prices Increased st111 further after 1972, and 1t is expected that such prices w111 continue to Increase since there will be a continued excesq of demand over the anticlpated supply (see Table 5-1).

Another Important fact which will have a direct bearing on a Sahel regional beef cattle development plan, is the statistical breakdown of the World's meat and livestock export trade. 6 . of the total trade of this commodity, 58.5218 accounted for by 'fresh ch1lled or frozen meats', a further 17.97 by 'dried and canned meats' with only 23.67 consigting of live animals. These World trade percentagee are significantly different from those of the Sahel nations?' where thay export no 'drièd or canned mat'. but 
do export 937 as live animals. The balance of the Sahel livestock and meat exports being 77, which is butchered in the abattoirs 8 . of the region with, small percentage, only $0.5 \%$ going on to a meat drying operation.

This trade breakdown is tmportant for the Sahel nations when determining their future markets in terms of countries and the type of beef products which these markets demand. Hence, the World demand will now be examined a little more closely. a. World Demand for Beef: It is generally considered that the quality of people's dietary habits are a reflection of their income levels and In $_{c}$ this regard there is a definite relationship between the levels of income and meat consfruption (see Chart $5-1$ ). With the rising incomes of many countries there is thus a corresponding rise inthe World demand for meat and livestock products; the western European countries alone import $66 z$ of the World's total?. However, these same developed western Eyropean nations are also among the largest exporters of meat and 11vestock products, with 49.57 of the total World export volume. ${ }^{10}$. But, it must be realized that much of the Eurgpean. trade is within the region due to the "health and economic barriers wich have been imposed on the Imports of meat products from the developing "cerries. Nevertheless, some of the new nations are able to export some : of their prodpcts to Europe, though it is only a small percentage 

of their total trade. Presently the developing countries only account for 18.27 of the dollar value of World meat trade, and of that, only a small percentage 11 . 18 exported to the European markets.

The above figures are important since it is the demands of the developed countries, particularly Furope, which may be of vital importance to the future of a beef industry in the Sahe1. Table $5-2$, provides a clear 1dea of just how that demand for livestock and processed meat has been increased in the few years from 1967 to 1972 . The demand is reflected not only in the increased quantity "which has been Imported, but also by the increased higher per unit prices which the importing markets have been prepared to pay.

Thus, on the demand side there is a very basic economic situation whereby prices have increased in response to the higher demands that suppliers have not been willing to meet at the lower prices.

What then of the supply side?

Are there any points to be observed in order to ascertain if there could be any value to the Sahel countries?

b. World Supply of Beef: Though pork, poultry, mutton and lamb constitute a ignificant proportion $(32.6 \pi)^{12}$ of the World's meat supply, this paper is concerned solely with the beef market potential. Hence, this section will examine only 

the supply of beef (67.4\% of the total World meat).

It was mentioned in the previous section ("World Demand for Beef") that the developing nations only account for 18.27 of the World's total trade. This figure should be qualifled further at this juncture by stating that the developing nations $^{13}$. only represent $18.1 \%$ of the World's beef supply. This small share of the beef export trade is in no way a reflection of the livestock production in the developing countries as is Indicated by Table 5-3. While the less developed nations only account for $18.1 \mathrm{x}$ of the World's beef exports, they do however, account for over 597 of the cattle population gf the Wotid. Since this percentage 18 so large, the obvious questions are:

With 597 of the World's cattle population, why do the developing nations not have a larger share of the total World meat trade?

Why are the developed nations prepared to pay higher prices for thelr beef imports rather than dpen up more trade potential with the emerging nations?

While the number of cattle in India may account for a percentage of the $59 x$ already stated, the answers to these two auestions leads to the next section, since there must obviously be some barriers to trade wich prevent the developed countries from Importing beef that 1s avallable In the less developed nations of the Horld. 
${ }^{\circ} 0$

\section{0}

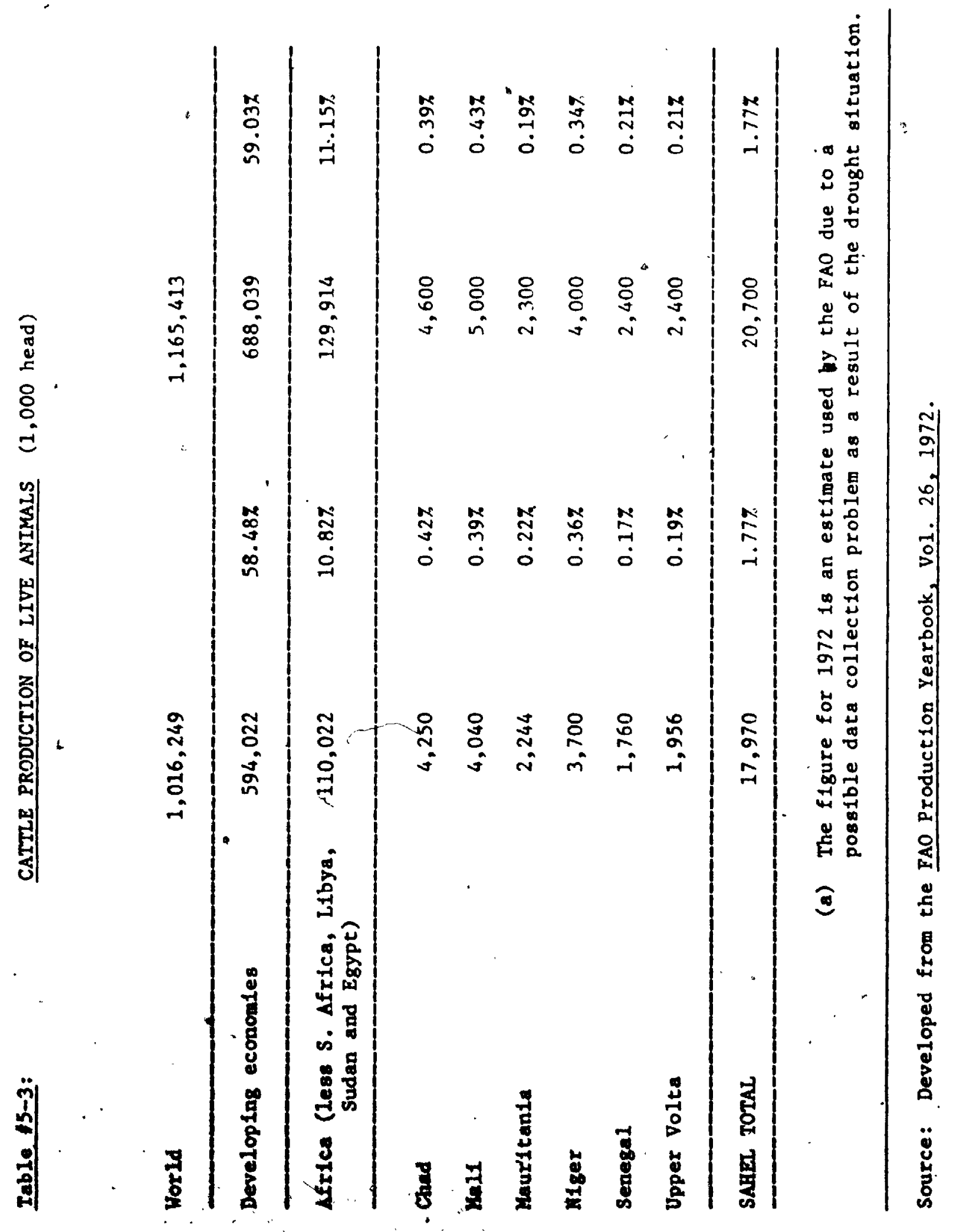


c. Beef Trade Barriers: The problems which will be defined here, while they pertain to the beef industry, are also applicable to the entire meat trade between developed and the developing nations.

The chief problems related to the barriers to trade which have been imposed by the main importing countries of North America and western Europe. The primary trade barriers are concerned with the quality and the continuity of supply frow the exporting countries. It is also important at this point to appreciate the reasons for these trade obstruction and the ways in which they operate.

There are two main reasons for the trade regulations; firstly, to protect the consumer from health risks; secondly, to protect the cattle industries of the importing councries from both animal diseases and the potentially lower priced imports.

1) Health Barriers: In all the developed countries, Imports are subject to l1censing." However, in order to obtain a permit, the abattoir facilities of the exportnation must satisfy the health requirements of the inporting country. In the case of processed meat this applies aleo to the processing plants of the exporting countries: But, this Inspection aspect only take care of the food polsoning and food-borne diseace olde of the 
Import trade. Also under the Health Barriers may be found various veterinary regulations which are designed to prevent the Import of an1mal diseases such as "footand-mouth" since these could have serlous economic consequences for the farmers of the 1mporting nations. While ouch regulations may be seen as a menace to trade for the developing countries, they must also be viewed in the light of the possible problems for any importing countries If such rules did not exist.

Clearly, these health barriers áre here to stay. Th1s means that if a livestock policy is to be developed for the Sahel which will involve trade between the Sahel nations and the developed World, particularly western Europe, then the Plan of chapter VIII must include ways by wh1ch the beef Industry of the Sahel will be able meet these Health Barrier requirements.

However, besides the health requirements, the more traditional type of economic trade barriers must be examined.

\section{1) Economic Trade Barriers: In most countries of the Horld} studies have shown that the average annual income of the rural areas 18 often below the incomes of the urban regions,

a fact which would seem to apply as much to the developed at the under-developed economies. Certalnly, both Canada. and Burope have, In recent years, had problems with their 

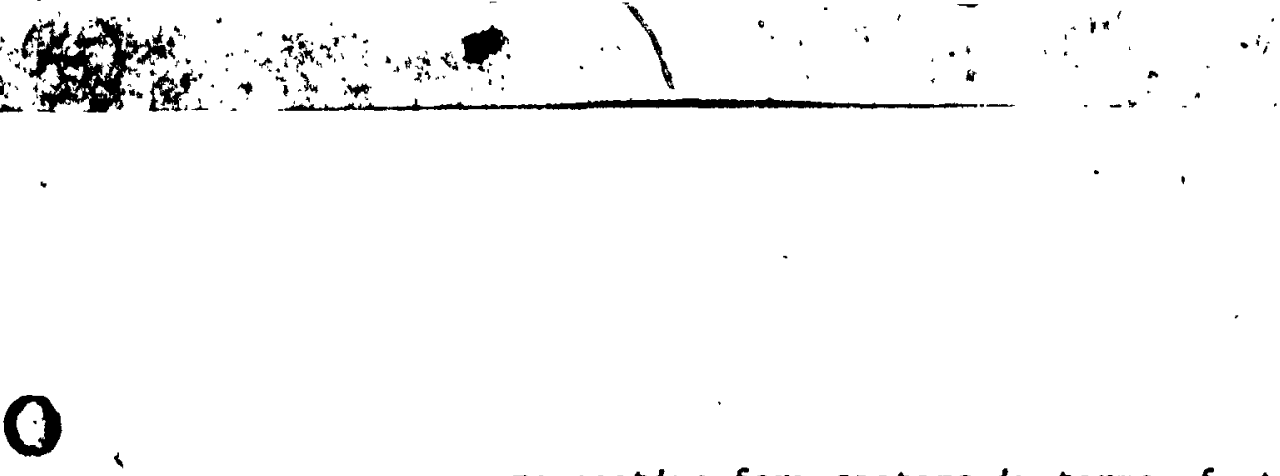

respective farm sectors in terms of strong demands to correct these income 1nequalities. In view of this situation, the countries of western Europe have had, as one of their primary objectives, the ralsing of these farm incomes.

This has been attempted on many agricultural products, including meat and livestock, by introducing measures designed to increase the domestic farm prices above that of the World markets. The methods have included the imposition of tariffs, variable levies and straight quotas on all agricultural products which would be in competition with the domestic supply of the importing countries. These economic barriers were based on the principal of short supply and high demand so that the domestic market producers could ask for, and obtain, higher prices for their produce.

It should be added that not all countries have used this approach in Europe. The United Kingdom relied upon the payments of direct subsidies to the producers, thus maintaining domestic prices at the World level. Clearly, such a situation in the United Kingdom is more able to permit the import of certain agricultural products from the less developed nations ince the dowestic products are at least price competitive. However, Britaln, like 
all other developed nations do have health barriers.

There are no barriers from the western European nations which spectifically apply only to the Sahel countries, since the barrlers wh1ch have been established were intended to apply equally to all nations. Thus, it cannot be sald that, should the Sahel develop a successful beef cattle lindustry the Sahel nations will be unfairly penalised, since this is clearly not the case.

However, though the strategy for the development of a Sahel beef industry (chapter VIII) will be able to suggest methods for meeting the heafth requirements of the importing countries. the economic barriers form another situation entirely. These barriers would have to be negotiated efther at the GATT meetings, 14 . or, directly by jan Inter-State Comittee $^{15}$. of the Sahelian Governments deghing with the individual prospective importing countries. In any case, these particular econowic barriers cannot be built into the livestock developwent strategy, since they are purely a problem for diplomatic resolution at the highes levels of the nations involved. However, it may also be that the Sahel nations prefer not to export to the markets of Europe, being Instead satisfied with the existing markets of Weat Africa.

Havlag eet forth the two primary classifications of trade barriere which extet, there 1s a third Iren which is of vital concorn to the prospetetive 1mportith cointries, and which way also 
be thought of as a barrier to trade - Continuity of Supply,

111) Continulty of Supply: While there 18 a very large potential for exports of beef from the developing countries which have the abflity to produce a viable beef cattle industry, it should also be noted that these developing nations almost all seem to be in the southern Hemisphere. This means that they are also subject to the posstbility of prolonged perlodic droughts, an aspect most relevant to the Sahel region. The vagaries of the weather not only prevent the fattening of the cattle but also lead to considerable herd depletion during drought years. There is another problem besides drought, and that is the endemic diseases which can serlously decimate the herds.

It is this potential for herd decimation through either disease or drought which can lead to qubstantial export reductions in any given year. Such fiuctuations In supply would inevitably be reflegfed in the prices for beef (low supply means that prices would theoretically be pushed upwards) which the importing nations would have to pay. These fluctuations can have a ripple effect throughout the economies of the importing countries, a factor to be afoided at almost any cost. Hence, it is" here suggested that 'continuity of supply', even at above 
average prices, is more important to the developed nations than an erratic supply at possibly lower prices in some years.

\section{RECENT DEVELOPMENTS IN BEEF TRADE STRATFGY}

Part of the increase in World beef prices mentioned in an earlier section of this chapter may be attributed to higher production costs in the exporting countries. But this higher production cost may also be interpreted as a reflection of a different trading strategy.

Most beef sold on the World markets used to be in the form of half or quarter carcasses with the butchering taking place In the importing country. However, in recent years, butchering Into foints, or steaks, has increasingly been undertaken by the exporting country. Two reasons may be sald to account for this change; the United Kingdom Imposed a ban on 'bone-in' beef from countries where 'foot-and-mouth' disease is endemic (a consequence of a belief that the disease can be transmitted in bone marrow or offal); and the demands of Supermarkets for pre-packaged meat, or restaurante for pre-packaged ateaks!

A further reason for the shift in the butchering process from dimporter to exporter any also be attributed to the syeten of grading wat into a consuner requirement and anufacturing 
standard (for soups, stews, and quick-frozen foods). This last factor 18 important because 1 t means that an avenue is open for beef from the developing countries. Through this trade route it can mean that imports (exports in cooked or froxen form are free of disease) will not be competing with the higher quality domestic beef produced for the direct consumer market. A start has already been made in this direction with Kenya beef going to the markets of the United Kingdom and sothe westernuropean nations. 18.

\section{THE FUTURE FOR BEEF}

Table 5-1, illustrated that by 1980 there could be a substantial beef shortage. While production is expected to fincrease by 29.57 between $1970^{\circ}$ and 1980 , demand will increase by 34.47 if supplies can be increased. Though this Table indicates a potential shortage of 1.6 million tons, it is based entirely on the existing production systems and the present trading patterns at constant prices.

Since beef profuction expansion in the developed nations 18 rather lintted, the importers will have to lean more and more towards the developing nations for their beef needs. Thus, the developing countries, and in particular the Sahel, w111 have to Improve both the quality and the quantity of the beef from the cattle industry. It should also be realised that the importing natlons expect to pay higher.prices by 1980 , partly on account of 

stems from the fact that, in the absence of a monetary economy, cattie have been the main form in which wealth could be accumulated.

When the productive potential of the'Sahel is viewed as a whole, particularly in light of the drought problems mentioned in chapters III and IV, it is clear that the present falire of beef cattle production relates to the fact that the nutritional requirements Epr cattle are not being met on a regular basis. Thus, this is another point which must be resolved th order to develop a strategy, since success w11l depnd upon attaining the correct relationship between feed resources and the stock numbers. However, since the major portion of the diet for beef cattle is derived from the consumption of range herbage and there is a direct relationship between the ratio, of feed and the number of cattle, there must also be a relationship between the land area and the cattle. Given this latter ratio concerning land ownership and cattle, then it could also be that land ownership occuples a central position in the search for a beef cattle development atrategy or Plan.

Under a system of copmunal land ownership, or tribal grazing rights, when a given area of. land is stocked to its maximum capacity the addition of one more head of beef will reduce. thẹ output of the herd as whole, although for the owner of 
infrastructure. The problem in marketing is really two-fold: firstly, to change the traditional system of marketing, which, although very effective in that it can deliver a live animal from producer to a consumer some 1,0000 to $1,500 \mathrm{~km}$ away, is often more costly than a more developed marketing system. 20. Secondly, it will be necessary to standardise the different systems the Individual Governments have of levying taxes, tariffs and other 11cence fees. 21.

Coupled with the distance problem mentioned above with reference to the traditional markets, there is another problem which must be considered. Markets must be thought of on a .. regional basis since it is impossible for a single country to obtain full benefit of the traditional system of exporting 'on-the-hoof'. . A regional system is necessary because of the long land borders, frequently crossed by the traditional nomad, allowing easy opportunity for stuggling, thereby short-circuiting any inftial efforts at market improvements by an individual nation.

\section{SURPARY}

In this chapter an attempt has been made to clarify the World market for beef cattle and also to view the main barriers to free trade which exlot between the developed and the developing nations. These barriers of 'bealth', 'econontce' and 'supply con- 
tinulty' were considered as general application to all the developing nations since they were not specifically formulated against the formation of a beef industry in the Sahel. These barriers were shown to be protective measures for the 1mporting' nations of the World. Thus, the strategy of chapter VIII'will have to devise a way to meet the standards being set by the importing countries, if the beef shortage predicted for 1980 (see Table $15-1$ ) is to be partially reduced by an expanding Sahel beef industry.

Recent developments in World beef trade strategy were also mentioned since the increased pre-export meat processing can have some added benefits for the Sahel economies in their efforts to develop backward and forward linkages from a beef industry.

Having briefly considered a few of the important aspects of the World situation with regard to beef, the problem facing beef caftle development in the Sahel nations was discussed. These problems were also noted as being of key importance for the strategy to be proposed in chapter VIII.

Despite the items considered in this chapter, such discussion still does not permit the immediate development of a beef Plan for the Sahel. Before that step may be taken, it is necessary, in the next chapter, to examine the fundanental requirements of a basic beef, catcle Industry such as the water needs, disease'control measures, feed and grazing requirements, marketing and the infrastructure. 


\section{FOOTNOTES}

1. Indicative World Plan for Agricultural Development to 1975 and 1985, published by the FAO, Rome, 1968. p.252.

2. World Animal Review, No. 4, 1972 published by the FAO, Rome, p.1.

3. Ib1d., p.1.

4. FAO Trade Yearbook, Vol, 26, 1072 and the United Nations Yearbook of Internattogal Trade Statistics 1970-1971

$\begin{array}{lr}1971 \text { World Trade Total } & \$ 348,000 \mathrm{~m} 111 \text { ion } \\ 1971 \text { Mee }\left.\right|^{\text {and Livestock }} & \$ 6,860 \text { million }\end{array}$

5. Price increases of $52 \pi$ for live animals and 417 for processed meat. Information developed on Table 5-2 from FAO Trade Yearbook, Vol. 26, 1972.

6. Developed from FAO Trade Yearbook, Vo1. 26, 1972. World Trade in thousands U.S. $\$(1972)$.
Live antmals
$\$ 2,220,757$
Fresh, chilled or frozen $5,071,451$
Dried and canned
$1,547,062$
$(23.6 \pi)$
$(58.5 \%)$
Total

$$
\$ 8,641,270
$$

7. 'Abattoirs' In this paper refers only to the slaughterhouse facilities, these being in no way connected with the meat processing plants.

8. FAO Trade Yearbook, Vol. 26, 1972 - Sahel Meat Trade 1972
Live animals
$\$ 63,499,000$
(93.0\%)
Fresh, chilled or frozen
Driéd and canned
$4,450,000$
$(6.5 \%)$
Total
219,000
$(0.5 \pi)$

9. FAO Trade Yearbook, Vol. 26, 1972 - World Imports 1972
World
Western Europe
$\$ 9,476,485,000,000$
$6,253,613,000,000$

10. FAO Trade Yearbook, Vol. 26, 1972 - World Exports 1972

World

Western Europe

Developing nations 
license, market tax, municipal tax, sanitary inspection fee, charge for certificate of origin, and fee for export permit. In addition, there is an export tax, and import tax, and, in some cases, a trans it tax. At the abattoir a market tax is levied, an ahattoir tax, a sanitary inspection charge, and perhaps another official tax. As a result, a large share of casts to marketers are for taxes, 458 if sold in Abidjan (from Nali), and 35 if sold in lago (from Nali) on $53 \%$ if sold in lome." 
0

\section{CHAPTER SIX}

THE BASIC REQUIREMENTS FOR A BEEF

\section{CATTLE INDUSTRY}

Introduction

Water requirements

Disease control

Feed and Grazing

Education and Manpower

Marketing and infrastructure

Summary and Conclusion 


\section{CHAPTER SIX}

THE BASIC REQUIREMENTS FOR A BEEF

CATTLE INDUSTRY

\section{INTRODUCTION}

4

The earlier chapter have made an attempt to provide a clear understanding of the Sahel economies and also the Important beef cattle. Additlonally, the current economic plight relating to the drought was discussed with the root-causes being pinpointed. In this chapter, the fundamental elements needed for the successful development of a beef cattle industry will be examined. Table 5-3, chapter $V$, showed that the Sahel would seem to have the basis of a substantial cattle population, at least according to the FAO estimates. Thus, the elements which must be considered for the viable future development of beef production are set forth as follows:-

- water requirements

- disease control

- Feed and grazing needs

- education and manpower

- marketing and infrastructure

While this chapter 111 go into some detall about the above requirements, there w11l be no attempt made to outline a beef Industry developsent etrategy at thls stage. . However, since the polnte lieted for axamination are alwo ralevant to other sectors

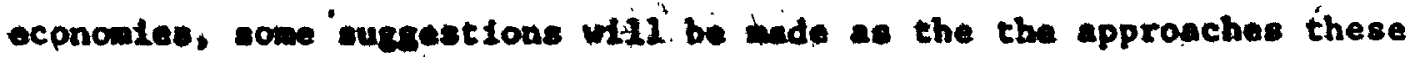



In the grasses of the pastureland, but during the dry season in the Sahel, the grasses dry, leading to the abandonment of any pastureland which does not have an abundant water supply. Hence, grazing areas which do have an adequate water supply become rapidly trodden down and over-grazed.

The practice of abandoning grazing areas without water and moving to pasturelands with water, is the normal pattern of the nomads in the Sahel!. Indeed, it is the system of transhumance which has permitted the development of a beef industry as it presently exists in the region. With the southerly migration in search of water and the northerly expansion of the agriculture? two questions arise which are even more germane tó this paper than the two questions posed at the start of the section.

'Should the beef industry be retalned as a viable sector" of the economies of the Sahel countries, desplte the ever decreasing pasture areas?

In the light of chapter $V$, where the Importance of beef to the Sahel was shown, the answer must be, yes. .

However, this answer, perforce, begs the question:

How can the beef industry be retained as an important part of the Sabel economiee? - 
The answer to this "second question can be simply stated;

1t can be accomplished by a policy of sound range management.

Unfortunately, the phrase can mean a hundred different

things to a hundred different people. However, in this paper

It 1 s suggested that once a pattern of water supply has been

developed whereby there is equilibrium between the water resources and the nutrient value of the pastures, this balance must be maintained by continuous management of both resources.

The water needs of livestock can now be set forth along with a few suggestions as to how the 'balance' can be arrived at and maintained:

Table 16-1: AVERAGE WATER CONSUMPTION DURING THE DRY SEASON

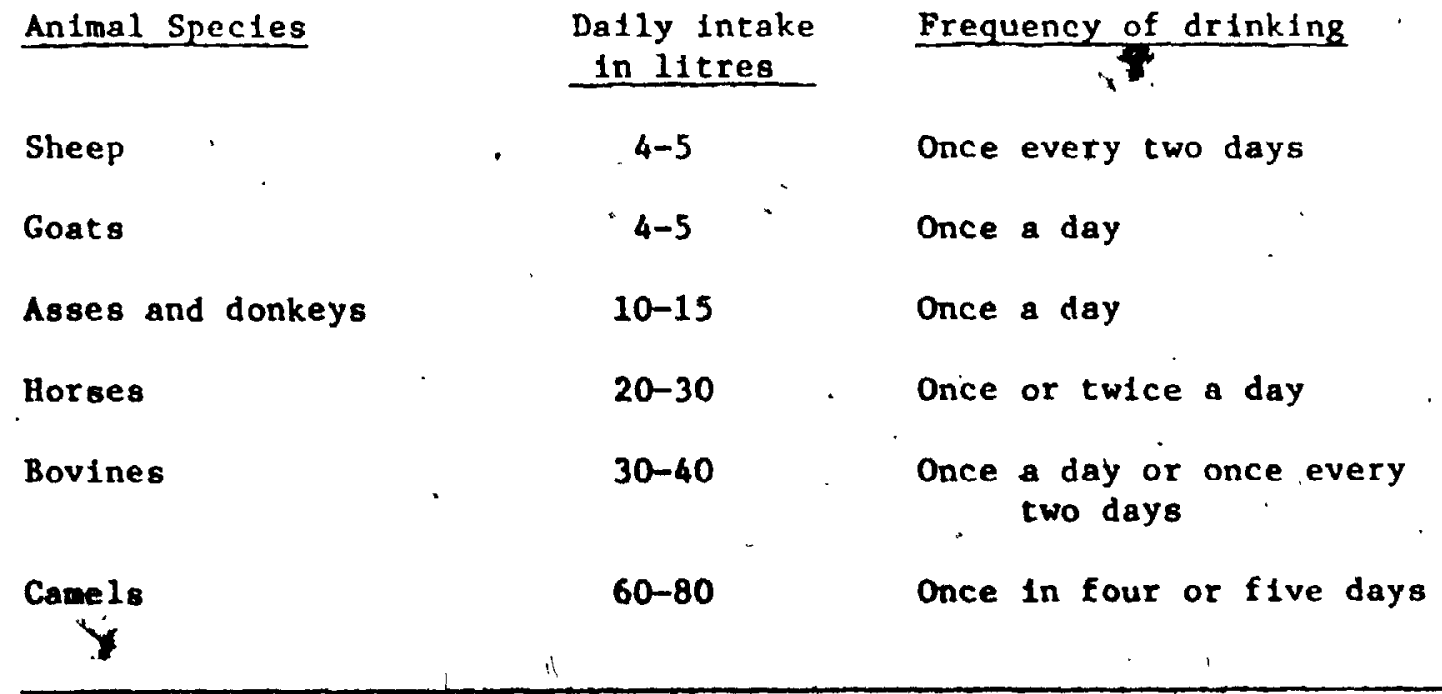

Source: "Water for Livestock in seat-arld zones" by J-P Baudelaire in Horld Antmel Review, Ho. 3, 1972, published by the FaO. 
Thus far in this chapter, four questions have arisen, but answers have only been provided to three of them. The unanswered question is,

How is this water to be obtained to annually sustain the dafly requirements of the entire Sahel livestock population?

Earlier, it was mentioned that this paper would not be concerned with the development of a water resource policy. However, before a concrete programe for the recovery and future development of a beef industry can be produced, certain things must be undertaken by the water resource planners.

The first task is clearly the compllation of an inventory of all surface and ground water avallable. At the same time, in confunction with agriculturalists, a map must be produced showing the land capabilities for each area, le., its value to cash crop or rangeland. From these two tasks, a third factor can be developed, namely the siting of water points to fulfill one or more of the following needs:

- for livestock along the transhumance routes

- for livestock in temporary grazing areas

- for livestock in permanent pasturelands

- for agriculture through irrigation

- to meet the requirements of the sedentary population

- to satisfy the needs of Industry, both present and future

It is now poesible to apell out in more detail exactly what is required by way of water point development as relevant to what 19 required by way of wacer point devel. 
the beef industry.

While the normal needs of livestock were presented (see Table 6-1), common sense will dictate that more water will be requifed when cattle must exert themselves crossing rough terrain instead of flat pasturelands. Further, the dafly requirements will vary'according to the molsture content of the cattle feed additions over and above the normal dried-up forage .

Previously, in chapter III, it was shown that the semiarid Sahel area had a very Iimited rainfalf of between $1.00 \mathrm{~mm}$ and 600mm annually (see Map 2 ): Under these cond1tions surface water is both scarce and irregular and hence, only the-sturdy drought resistant animals of the Sahel can endure the hardships imposed by this condition. Even with the right adaptation of cattle, which is clearly the case with the special Sahel breed of zebu cattle, water must be managed to provide sufficient supply according to the season and local conditions. Thus, water must be controlled at least from quantity standpoint.

However, under a sound water management programme, the control really commences before the water resource 18 brought into ise. Prlor to establishing a water point, a chentcal analysis must be ade to ensure that the total ealinity is within th tolerable 1intes 4 . and that it containe no toxic salts such as nutrates, 
of distributing water at all times and in almost unlimited quantities. Whereas during, at lbast the latter part of the dry season, the temporary water sites will be drted up, the permanent locations must be rellable and function even during periods of drought. It 18 the location and spacing of these permanent water points which must be very carefully planned by the water resource development speclalist, because, the $=-$ entire success of a viable beef cattle industry is dependent upon their siting and reliablitity.

Concerning'tice location and spacing, it should be mentioned that though the number and distance between them will depend to a large degree on the resources of the region in relation to the extent of the pasture, if at all possible they should not involve more than several hours cattle trekking distance $(10-15 \mathrm{~km}$ for beef cattle)." Th1s means up to $30 \mathrm{~km}$ distance between permanent points.

It was suggested that these permanent sites were really the key to the beef industry. This is also where the high investment costs occur because the sttes must, be able to serve the needs of a large number of stock. Such locations not only regulre labour for inftial construction, but they also need a permanent buflding and water. storage syatem, In addition to a reliable source pf power to pump water up from the vell. The coet of pump power ' 
can vary considerably according to whether one uses manual labour, animal traction, wind power, thermal power or diesel power. However, whatever power 18 used, there must also be a Warden Service to be responsible for repairs, operation and maintenance. Having spoken at some length about water points as they concern the beef Industry, it should be mentioned that there are other water needs which are Important to the beef cattle development strategy. Here it is important to remember that beef cattle is not a sector on 1 ts own, but that it is really part of the agricultural sector.

In the tabulation of water requirements was 1 isted 'for agriculture by irrigation'. While this is most vital for export cash crop production such as cotton 11nt, cotton seed and groundnuts, or alternately, for the domestically needed millet or sorghum, it may also be considered crucial for the Irrigation of fodder crops, which are a necessary ttem for standard quality beef cattle feeding.

This development of irrigation for agriculture also perats the creation of large scale industries derived from agriculture and livestock. But such industries in turn require a large, constant water supply for both power and transportation. Thus, large rivers can becone important agro-industry sites.

In this section, though it has been primartly concerned with the water requirements of the beef cattle industry, it, fias 
deemed necessary to suggest the primary approach needed for development of a total water resource programme. Th1s has been done because, while water is Important to livestock, it. Is also vital to every other sector of the Sahel economies. Without the proper coordinated development of hydraulic resources, the Sahel would remain in a permanent state of emergency: No water, means not only the death of people and their animals, but in addition, no agricultural production, no industrial development, no exports and no money to pay for the much needed imports.

While this section discussed briefly the location, spacing and even alluded to the cost of water points, mention must be made of the problem of "water point sanftation". Many livestock diseases are spread by the cattle themselves through their pollution of what water resources there are at the moment. Thus, the next section will examine the requirements of 'disease control' as they are relevant to beef development.

$$
\text { at. }
$$

\section{DISEASE CONTROL}

In chapter $v$, it was shown that livestock production in the developing economies, especlally in beef cattle, had a high potential for earning foreign exchange. Unfortumately, the exploitation of this potential has been seriously lmpeded in the Sahel countries by their inability to enter the very profitable 
overseas markets due to health restrictions imposed by the importing countries.

The FAO, in Rome, has long advocated that members of both the FAO and the office International des Eplzooties (OIE) concentrate on the development of "disease-free zones". Only with such zones will any of the developing natlons be able to surmount the health barriers imposed by the potential markets.

In order to establish disease-free zones, as have heen set up in Kenya and Tanzania,' the countrles of the Sahel require a substantial veterinary organisation. Such an organisation must develop a high degree of control over all antmal diseases in the Sahel, a very difficult-task when dealing with the nomadic herds. This control and this organisation becomes, of course, another high cast investment since, not only must enough people be trained so that there are adequate staff; but they must also have sufficient laboratiory facilfties to carry out their important work testing, research and Immunisation of all antmals. In addition, they must be staffed sufficlently to be able to maintain a survey of the wild animal disease situation.

What measures can be taken to develop and matntain disease-free zones?

The above question w111 be anwiered brief1y at this point. 
way of $11 \mathrm{fe}$, a polnt which will be considered later in chapter VIII. However, this people movement control really also goes on to the question of edugation which this chapter will consider in a later section.

All the points mentioned above, concerning the development of one or more disease-free zones, hinge on the competence of the veterinary systen, since without their organisation and knowledge no disease control would be possible. Hence, the livestock mortality rate would increase unabated, destroying the entire beef industry.

The veterinary organisation is also fundamental for the abattoirs concerned with export production. These abattofrs would have to be constructed and staffed in a manner that would satisfy the meat hygiene requirements of the potential importing nations.

These disease-free zones can only prove successful and beneficial provided that there are adequate supplies of feed and grazing for the livestock which are under control. This pofnt will be examined in the next section. However, disease-free areas with an adequate supply are only part of the solution. These * zones, plus the abattorrs, must be well controlled and properly staffed by trained people: To this end, the nomadic herdsmen must fully understand and be in favour of what is being attempted, 
thereby setting-up yet another point related to a later section of this chapter, that of "Education and Manpower".

\section{FEED AND GRAZING}

Primar1ly, as was shown in an earlier chapter, the livestock industry as such, evolved over many years. With this evolution the nomadic herdsmen also developed ways of keeping their herds in balance according to the avallable feed supplies. To ensure this 'balance' the nomads utilized two important methods:

1. If pasture were being overgrazed

(a) many animals would die bringing about a 'balance'

(b) some antmals would be loans to another herdsman, or sedenta farmer, thus part of the herd would be transf to another grazing area. ,

2. In times of abubora rains, the vegetation for grazing would be pleatiful causing herds to grow fat and healthier, thus multiplying more rapidly. Under the circumstances the herdsmen would be able to increase his wealth, and more stocks would arrive at the markets having survived the long trek.

With these traditional methods of the herdsmeny the cattle herds were brought into 'balance' with the avallable food supplies. Rut yet, If the nomadic herdmman sore askẻd the following question:

How many head of livestock can the available pastureland s support?

the herdman certainly would not be able to provide a very scientific ariswer, desplte his huving been able to maintaln a 'balance' during 
normal times,' and for many years. Most assuredly the nomadic method worked well for the initlal development of the beef industry. However, in terms of a modern development plan in which the cattle segment plays a vital and consistent role, a more preclse method of balancing animals to pasturelands must be devised.

\section{Unfortunately, there is very little data avallable for} the Sahel region as to how many head of cattle can be grazed on the avallable acreage. Thus, such information must be developed as soon as possible by the new Government research centers in the area. Nevertheless, in the 1nterim, it is still possible to create a strategy for recovery and development of the beef Industry. This step can be undertaken, since the herds have been decimated 10 . by the prolonged drought which has caused virtually the total destruction of the beef industry. However, during the interval in which the industry is in the recovery stage, and before it moves into the future stage of modernisation with consistency of production, much research must be undertaken.

Such research must be oriented to the questions of types of vegetation and land use. A land sulvey must be developed covering vegetation, state of land use and/or deterioration, the grazing capacity and the nutrient value of the grazing areas. This agrlcultural research should be combined with a substantial study 
of climatology and meteorology. After which the combined study results should be made avallable to the water resource planners.

Though water was mentioned as the primary factor in a beef cattle industry, the second pre-requisite must clearly be a knowledge of the fauna, flora and the fodder crop varletles. of the research suggested in this and the previous paragraphs, some work has already been undertaken in regards to certain spectific areas by a number of different agencies: notably Institut d' Elevage et de Médecine vétértnalre (IENTT) in Mali and Miger; Kew Herbarium for Sudan and Northern Nigeria; United Nations Educational, Scientific and Cultural organisation (UNESCO) for Africa in total. These plus some other agencies such the FAO, office de la Recherche Scientifique Outre-mer (ORSTOM), Institut Fondemental d' Afrique Noire (IFAN) and the Paris Museum of Natural History would be 1deally sulted to continue this research so that the information would be avallable as early as possible.

While this section seems generally to have been concerned with the number of head of cattle which can be supported by the pasturelands of the Sahel, the dost important question really concerns the possibility of Improving the existing stock breeds. No evidence has been found about research on cattle breeds in the Sahel. This may mean that there 18 an underlying assumption 
that the present zebu cattle are best sulted for the semi-arid Sahel climate. However, chapter VII, will discuss cattle breeds more fully.

In November 1968, at a foint meeting of the FAO and the World Health Organisation (WHO), the decision was made to direct attention to the problems of productivity and cattle breeding in hot climates. Subsequently, a study was made into the relationship between cattle breeds in Asta, Africa and rurope. These first efforts of the FAO and wHo were printed in "Codex Alimentorius", which was an attempt to establish guldelines for the sultability of cattle breeds for the various levels of management (intensive, semi-intensive, extensive and nomadic) under varying conditions of climate and terrain.

In this section concerning "feeding and grazing", while time was spent on the question of avallable pastures, and the point of breeding was mentioned, no considerations have been made. about feed additives or diet supplements. While these feed additives such as.urea, bufret, molasses and NPN factors can be most heloful for the growth and health of cattle, they may not be considered to be a fundamental requirement for a beef cattle industry. Thus, they w11l be considered more fully in chapter VII of this paper. 


\section{EDUCATION AND MANPOHER}

How many people are required and what education must they be given if a modèrn beef cattle industry 18 to be developed?

While this question, or one simflar, is possibiy the most of ten asked question in the developing countries, there is no clear answer. However, it is general1y conceded that $1 t$ will be many years before the developing countries have enough trained ma wer to provide entirely for their orm growth.

If an attempt is made to answer this question with Lgard to the Sahel countries $1 \mathrm{t}$ w11 prove impossible. While it 1s known that there are many links in the beef Industry production chain, it is still not possible to state how many people are required even in this one industry. Clearly the,first 1ink of the beef chain would consist of the nomadic herdsmen. But what education do they need? They must at least have some undergtanding of water control and pasture regulations. 1 . The next link must be the sedentary agriculatural people in the fodder crop production. They also must recelve some education and training, since their knowledge and farming ability can do much to increase the yleld per acre of fodder cropa. These sedentary farmers must also become even wore Important as a link in the future, because fodder growth and atorage can do wuch to prevent more losees from drought in yaars to cowe. Other 1ink which way be considered part of the 
beef chain are the abattolr personnel, followed by the people involved in all phases of transportation, marketing, water management and disease control. Obviously the demands of the nomadic herdsmen upon the formal education system are not too high. But when considering the abattolr people, the veterinary system must also be viewed, since it is this system which is involved in all the subsequent movements and the treatment of cattle.

How many people are needed in the veterinary system and what costs wll be incurred in their training?

In the previous section, it was mentioned that the FAO and VHO were in the process of developing a listing of stock breeds in the "Codex Alimentorfus", which would permit consideration of different cattle breeds possibly more suited to a certain region. Since no data is available concerning the personnel requirements of the various economic sectors, the FAO 1s developing a tabulation similar to the "Codex Alimentorfus" but this time concerning people, the "Manpover Profile"." This Is to be a listing by service, and by sectors of the economies, which will show the numbers and training of personnel actually employed. Such a table w1ll be based upon the experlences of many different countries in the World. On completion it could prove to be a most useful tool for planners and developers, when they begin to consider the complex situation concerning nanpower numbers and the training levels needed. 
So far In this section the interest has been resting upon the sectoral manpower and educational requirements. But the present shortage of trained people should not be taken as an implication that nothing has been done in the past. All six countries of the Sahel had a system whereby there was a full slate of education institutes. Unfortunately, the educational development mainly provided tralned people for salaried employment in the modern sector, the preference being for the Public sector. . I $^{3}$ is, of course, true that the modern sector represented only. a minute proportion of the national activities and thus there was a fairly high unemployment for school-leavers (meaning drop-outs and graduates). This employment aspect may also be attributed to the fact that the school system seemed to be expanding more rapidly than the economy (see Table 6-2) and the rate at which new johs were being created.

It would seem that the basic educational establishments were being treated as an end in themselves, not actually tied to the needs of economic growth. However, over the past ten years, UNESCo ] has provided assistance to the Sahel zone through the UNDP, and the International Bank for Reconstruction and Development (IBRD) and the United Mations International Childrens Education Fund (INICEF) profects, ${ }^{14}$. with the following main objectives in view:

1. To help States in the modernisation of 'formal education systems; new types of teachers to neet local needs (Niger); redefindtion of education needs (Senegal); establishment of rural education centrea (Upper Volta).

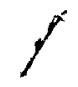


O

O

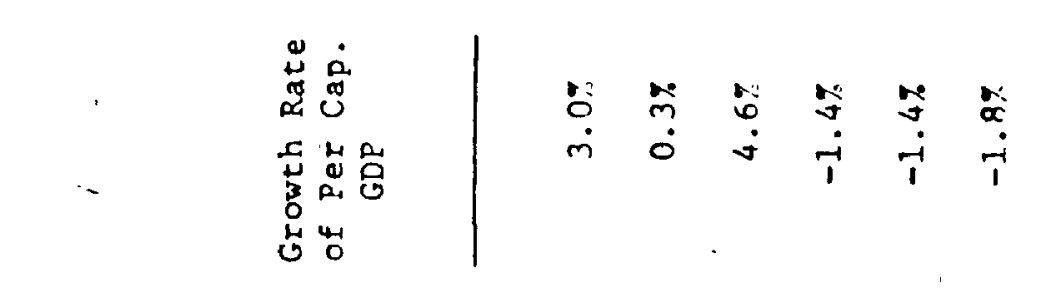

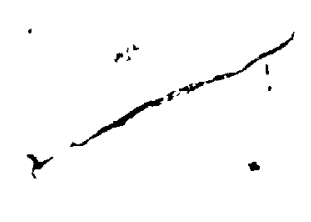


2. To help states to develop non-formal education systems; functional literacy (Mal1); educational radio (Senegal).

The new systems of education mugt be organised so as to enable them to break free of the constraints gradually Imposed by the traditional institutional methods.

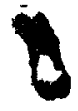

What has been mentioned so far, would indicate that

the FAO "Manpower Profte" could help considerably in the determination of the Sahel manpower requirements, both generally and in the beef cattle industry. In addition, it has been shown that, for a few years the educational system has been in the process of undergoing a change to ensure the functionality of education. Thus, the needs of manpower will be more closely satisfled in the future, particularly the developing beef cattle Industry's needs.

\section{MARRETING AND INFRASTRUCTURE}

f

This section should commence by an examination of the various products of the Sahel and their respective reglonal markets. But since the Sahel countries produce basically the same items, there 1s 11ttle trade generated among themselves, particularly in beef. Most of the agricultural and livestock production is consumed locally and in the larger urban centres which are therefore fairly close to the areas of production and hence require 1ittle in the way of a transportation infrastructure. Of the elx Sahel countries, 
only Mauritania 1mports any quantity of food supplies, and this she can well afford to do because of the forelgn exchange earnings from the orquines.

There are growing markets in the coastal cointries for cattle from the Sahel, Ivory Coast being the biggest Importer of Sahel cattle. 15 . Once again this type of locallsed market had 11ttle need for a transportation infrastructure since the cattlf are exported 'on-the-hoof'. 16 . Under these existing traditional methods of scattered cattle production there would seem to be no need for any increase in the already scant transportation sector. Unfortunately, with the system of exporting 'on-the-hoof' there is a conslderable welght loss by cattle and an accompanying deterforation of their health. This whole facet could be 1mproved, given that these same cattle were exported by road or rall transport. In fact, 1t, is very probable that the additional cost of transporty could be more than pald for by the increased sale price derived from a higher quality export product. ${ }^{17}$. Basically this export 'onthe-hoof' ieans that the Sahel countries are missing the full econonic benefits of several links in the development chain of a beef Industry.

One of these links would be the abattoir industry, which could be more productive and important to the economies if they wre pernltted to process the additlonal exports. This abattoir 

modern beef Industry covering such 1tems as:

- water

- disease control

- feed and grazing

- education and manpower

- marketing and infrastructure

Each of the above have been explored in some detall and some proposals have been made as to what steps can be taken for research and development. Such suggestions have been made for the consideration mainly of the Individual sector planners, because the beef Industry must be developed as part of a totally integrated economic structure.

However, having set forth the needs of the beef cattle, the position is still not clear to propose a strategy for heef cattle recovery and development. Hence the next chapter examines some of the recent research that has been undertaken in other countries which could prove helpful to the Sahel. 


SOME RESEARCH UNDERTAKEN WHICH COULD

HAVE VALUABLE APPLICATION

IN THE SAHEL

Introduction

Pasture improvements on traditional grazing

a. Solls

b. Grass burning

c. Pasture for extensive grazing

(1) Townsville Lucerne

(1i) Stocking rates of pasture

Introduction of modernisation technology

a. Pert1lisers

b. Cattle feed

(1) Fodder crops - maize, sorghum, millet

(11) Feed supplements - groundnut, cottonseed, molasses, urea

Cattle disease

a. Trypanosomidsis

b. Contaglous bovine plueropneumonia

c. Rinderpest

d. Foot-and-mouth

\section{Cattle Breeds}

a. N'Dama

b. West African Shorthorns

c. Maure

d. Asnouak

- Sokoto

f. Pulani

8. Tur18.

Sumary 


Map 15:

AUSTRALIAN RESEARCH STATIONS

Q

l

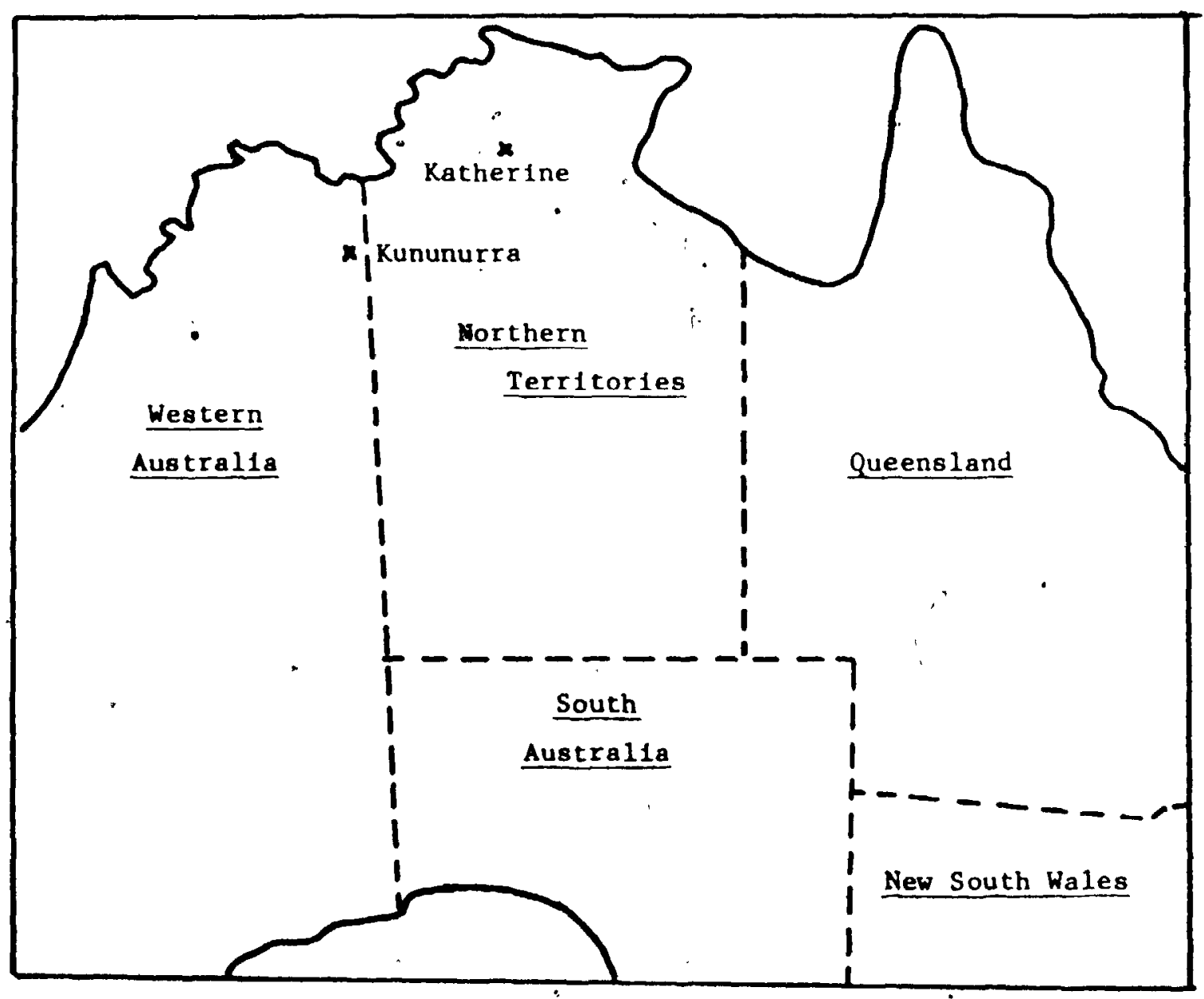

Average Annual Rainfall: 1950-1960

Kununurra

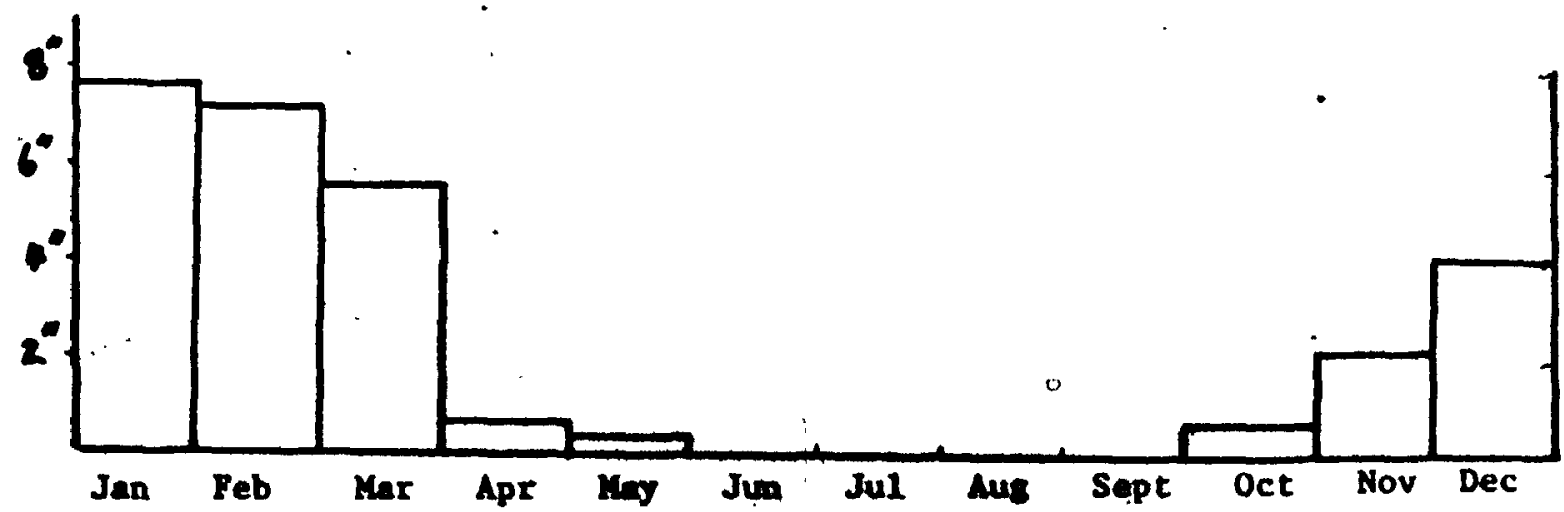

Source: Australian Journal of Bupertental Arrfculture and Animal Huabandry, Vo1.17, 1967. p.533. 
... Effective rainfall is law due to the high evaporati 1 rates and the rapid run-off of rain water, particularly where penetration is poor, as in the overgrazed areas."

Temperatures are not as high as the Sahel though, since Kununurra's temperatures only exceed $100^{\circ} F$ for two months of the year.

Though a brief statement of KRS, Kununurra was not necessarily germane at this point, it has been included because so much of the experimentation from the Australian research facllity will be quoted in this chapter as being very useful in the Sahel. No attempt 18 made to provide descriptions of any other regions since the added Information would not be relevant to the research results 11sted in the following pages.

The data presented in this chapter will be categorlsed under several malin headings which, in turn, reflect some of the major elements of any beef cattle Industry:

(1) Pasture Improvements on Traditional Grazing Solls - Including grass burning Pastures for extensive grazing - including Townsille Lucerne and stock rates

(11) Introduction of Hodernieation Technology Bertilloers Cattle feeds - Fodder crops and feed supplements

(111) Cattle Disenses

(1v) Cattle Breeds

PASTURE IMPROVAGMTS ON TRADITIOMAL GRzING

In the arid region of the sabel the problen which the 
nowadic herdsmen really face, and thus, the Goveraments of the Sahel nations, 1a how to prevent land degradation which in essence becomes a matter of the adjustment of stock numbers to the natural feeding resources. Clearly, frow what has been mentioned in chapter VI, Increasing the grazing presstres beyond the limits set by the dry season reduces forage and fodder resources and leads to depletion. It 18 unfortunate that little 18 known ábout the possibilities of perlodic re-sowing, but the low carrying capacity places an obvious ifmitation upon the capital investment for pasture improvement. Thus, returns on investment must, perforce, be low in the short run fand hence, any investments of a re-pasturing nature would have to be Government funds, or external a1d. Nevertheless, despite the low réturn on Investments, pasture production and 1mprovement must be the main support of an beef cattle industry. Already major developments have takor place in pasture improvement in the humld zones ${ }^{3 .}$ (over 1524 mm rainfg11. annually), namely South-East Asia, Central America and the West Indies, but the arid zone research has been largely neglected.,

When apimals go hungry for long periods, as during drought, . they lose weight and maturity is delayed for years, resulting in slaughtering of catcle at anything up to 7 years of age. Under these poor nutritional conditions there is often a break in the breeding cjcle so that the calving percentages are unduly low and calving intervals too long, aking it difficult to antain herd numbers 
and at the same time provide cattle for slaughter. ${ }^{4}$. While breeding and control of disease are important, under such conditions, first attention must be given to the problem of adequate nutrition through out the life of the cattle. To this end, it 18 important to examine the whole problem of fodder, resources, since the pastures will only provide the basic needs of the cattle during the dry season. Therefore, supplementary feed will be required at other t1mes of the year (see the strategy of chapter VIII). Though the question of supplementary feed production 1s really outside the scope of this paper, and the strategy w11l make a case for supplementary feed, the actual development of such a resource truly becomes part of the agricultural development strategy as 4 , relates to the sedentary farmer.

It it the Agricultural Development Strategy which w11 have to provide information on the management of the pqutureland and its fertiliser treatment, the techniques of plant introduction, and the source of supply, of seeds (legupes and grasses) for incorporation into the existing swards with, or whthout pre-cultivation. The strategy for the sedentary farmer wil also have to provide information on foddex conservation and the harvesting and storage of congerved feeds; pluo how far 1rrigation 18 posplble having regard to capltal costs as well as the water resources.

C. So11e: What then of the so11s which are the basis of any Improved pactures?

In general, 1t can bi and that the maln fact is that 
the pasturelands of the Sahel are nitrogen-deficient which results in low-protein herbage." Th1s 18 particularly noticeable in areas where $1 t$ has been the practice to fire the grass every dry season.' J.Hl. Topps,' states:

"...proved bey ond a doubt that mitrogen $(N)$ is the chief deficiency in the herbage for many months of the year. low $N$ content coupled with the fibrous and coarse indigestible nature of the grazing causes a retardation of the fermentation and diges tive processes in the gut with a consequent lowering of the proportion of food diges ted. Intake is also reduced ... "leading to weight loss"... which if prolonged may be associated with a high incidence of infertility in the breeding females".

Nitrogen 18 an element which must be present if high yleld

dry-matter and protein yields are to be obtained from pastures on the existing Sahel soils.

b. Grass Burning: ${ }^{8}$. Pastoral tribes of the Sahel have long used burning as a means of securing successional grazing for their herds; cattle will eat, and flourlsh, on the young leaves of most grasses, even those species whose mature leaves are unpalatable and useless for foot. As the grasses grow older the leaves become unpalatable, thus the burning clears the way for new young shoots.

Durning 18 perhaps one of the most common tools th the management of uncultivated nomadic pastures, but 1ts value for the successful recovery and continued development of a beef cattle industry is definitely subject to question. The effects of 'buraing' Includes the fact that those parts of vegetation 
of chapter VIII. There was no change in the relative proportion of the three major pasture specles; perennial grass remalned dominant with the bi-ennial 13 , burn. But, this was not a result based on his experiments concerning an annual burn and the burn every five years. In these cases there was a tremendous increase in the annual pasture species in relation to the perennial species. ${ }^{14}$

of the soll resource in general it should be mentioned that a knowledge of the solls is a basic requirement for the planning of agricultural development and irrigation projects. To this end, the FAO and IFAN have combined their efforts to develop a comprehensive soll map of West Africa, which includes all the Sahel countries. The map, ${ }^{16}$, when avallable, will become a useful instrument of education, research and soll resource evaluation.

Logically, the use of fertilisers could be considered under the sub-heading of "solls" but this would draw this section into a full discussion of soil chemistry and the accompanying chemical benefits of fert1lisers. Thus, to avold such soll chemlstry data which, though interesting, is not immediately helpful to the beef cattle development strategy, fertilisers will be considered only as they relate to Increasing yields of fodder crops in a later section of this chapter under the heading of, "Introduction of Modernisation of Technology". 


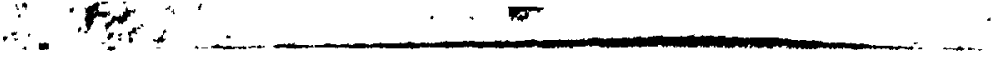

c. Pastures for Extensive Grazing: Thus far, little work has been carrled out on the actual pasture analysis of the Sahel region. Controlled breeding, weaning or supplementation are not practiced and therefore cattle conditions may be deemed to be similar to those which existed for the early settlers in Australia's Northern Territory." During the wet season there was a flush of nutrition forage, followed by a long dry season when growth ceased and the pastures decreased in quality as the season progressed. In the Sahel, the dependance of cattle on the pastures is complete, and thu's changes in pasture quality, 1.e. protein content, are quickly reflected In changes in cattle body welghts. During the wet season, there are welght gains due to the improved grazing on the lush pastures; in the early months of the dry season, the cattle exhiblt a zero weight change with the main welght losses occuring during the latter months of the dry season, when pastures are at very low levels of crude protein and phosphorus. 18.

While Robinson and Sageman analysed the nutritive, value of some pasture spectes during the late dry season and cohfirmed the gradusl loss of phosphorus, protein and calcium, they falled to explain why this change took place. However, during the course of their observations they did note something else of importance, 19.

"...that perennial pasture species, by virtue of their higher nutritive value during the late dry seas on, are superior to annual species (for cattle grazing)..." 
This higher nutritive value of perennial pastures 18 important because 1t t1es in with the 'b1-annual burn' and the 'flve year burn' (these belng the burn frequencles whth which the perennial grasses remained dominant over the annual grasses), and thus, both factors have 1mportant strategy 1mplications. It should also be noted that with the perennial grasses the 'voluntary Intake of dry matter' was higher, and the 'dry matter digestibility' percentage was also higher than the annual species. 20.

(1) Townsville Lucerne (stylosanthes humil1s HBK) $:^{21}$ Having regard to the sharp contrast in the Sahel between the wet and dry geason, herbage which retains its nutrient value into the dry pertod is of particular value. To this end, the merits of legumes ${ }^{22}$. such as Townsille Lucerne must be considered. To provide good grazing outside the period of active growth (the wet season) is very difficult under the conditions of the Sahel climate, so It could be possible that the grazing animals will require sowe form of supplementary feeding. Under the normal methods of supplementary' feeding, which will be considered later in th1s chapter under, "Cattle Feed Supplemente", there are Important econontc questions Involved and a number of technical problew which must be considered. However, in the sabel, sanding Tomoville Lucerne may be fesstbie as a 

when the area to be sown 18 a vast region for extenive grazing. Fortunately, some experimentation has been undertaken to answer the questions of "When?" and "How?" to sow Townsville Lucerne. H.P. Mrller, 26. carried out experiments to evaluate three sowing tests on native pastures that had not been cultivated and neither had the trees been cleared. It 1s obvious that any lengthy soll preparation in the grazing region of the Sahel would be very time consuming and costly; therefore, Miller's results could have important benef1ts for the Sahel.

Wille tested three seeding rates under three different pasture conditions:

(a) Heavy grazing in the previous wet season

(b) Late dry season 'burning'

(c) Barly wet season 'burning'

He showed that good stands of Townsville Lucerne could be established in uncleared perennial pastures without cultIvation, 27 . and that 1 t 18 possible to cover a large area in - short time by alrcraft seeding. 28 .

Mller further showed that, under favourable weather conditlons, Townsville Lucerne would

".. germirate rapidly and seedlings were observed at the open cotyledon stage 24 hours after sowing."

It 1s the aspect of 'fovourable weather conditions' which would aea 1mportant for the results Miler obtained, since 


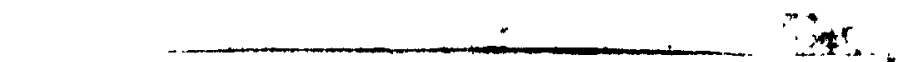

rainfall is most cruclal within 24 hours of the sowing. Thus, h1s results call for accurate forecasting of the cyclonic spells which would provide the much needed rain. 29.

For possible later reference concerning fodder crop production, one other result of Miller's experimentation 18 useful to note: The dry-matter yleld was an average of 5,870 1b8. per acre on unprepared land, but simflar research on Townoville Lucerne in 1956-1957 ylelded only 5,950 1bs. per acre on cleared cultivated pastures. 30 .

(11) Stocking Rates (carrying capac1ty) of Pastures: Stocking rates may be considered as a third method of pasture 1mprovement, though it 18 unfortunately the one to which a precise answer cannot be given for the Sahel. Phillips, 31. discussed the carrylng capacity of the natural pasturage in different troplcal reglons and suggested various cattle stocking rates. These rates ranged from a high of 1 acre per mature animal in forest regions, to a low of 40-100 acres or. wore per beast in sub-desert areas. While the later flgure of 40-100 acres per animal (16-40 hectares per animal) 1. not necessar1ly helpful, it may be considered as a startIng point as far as beef strategy development is concerned, for the Sahel.

Carrying capacitles have been the source bf considerable research in most coumeries of the World, but the results of 
this type of research cannot be directly applied to the

Sahel. Th1s may be conflrmed by the following, 32 .

"The carrying capacity of spear-grass pasture at the main spear-grass experiment centre (Australia) has been raised from 1 beast to 9 acres to 7 beas $t$ to 2 acres, and a liveweight increase raised from a mean of $22 \mathrm{lbs}$ to $217 \mathrm{lbs}$ per acre per annum through the use of the legume Tawns ville lucerne and the appropriate nutrients."

While the above Information would seem an added plus for the use of Townsville Lucerne, this does not guarantee the same results would be obtained in the Sahel. Dry matter ylelds per acre may vary according to the climatic data of the areas 1nvolved. Also, with regard to cattle, different strains of cattle have dfferent feed requirements and corresponding 'feed to welght-gain' converstion factors. In fact, the 'feed to weight-gatn' factor vartes considerably on a given type of pasture, since the protein yleld varles betweet the wet and the dry season feeding. 33 . Reslly, the otocking rate becomes very much a question of the economic justification for a given expenditure of money on costly pasture improvements. The following extract. 18 an example of the 'econonic justification' question; 34 . $\checkmark$

"In semi-arid pastoral areas, 25 acres of land may be required to carry a cattle beast which may take 6 years to reach.market condition and eventually sell for 25 pounds. By introducing a bush-control measure requiring an expenditure of 30 shiclings per acre and which requires repeating every 6 years, a better quality animal fetching 35 pounds may be marketed after only 3.5 years from 15 acres of improved land. Thus, 
the gross return would have been increased from 3.3 shillings to 13.3 shillings per acre per annun at a cast of only 5 shillings per acre per annwin."

There are, however, many other avenues for expenditure which can have a direct bearing on the carrying capacity of a given pasture. These may Include such items as a pipe system for water, the application of fertilisers 35 . to Increase the carrying capactey per acre by Increasing the liveweight production, the trangplanting and planting of grass or legumes, fencing and 1rrigation.

In sumation of the stocking rate question, it can best be assessed by separate calculations for each area of the Sahel which may be under consideration for beef cattle production. This is clearly so, since the economic circumatances w1ll vary greatly from one country to another, and It 18 these circumstances which will affect the cost of Inputs and the spbsequent value of outputs. Thus, the accruing returns on investment will depend on the system of magement practiced, the type of cattle utilising the un1mproved pastures, the prevalling prices for the final product as well as on the biological efflctency of the production iystem.

Having examined briefly some of the important facts, or experimente, concerned with "Pasture Improvenent" which can have useful Iaplications for the beef strategs of chapter VIII, the next section 


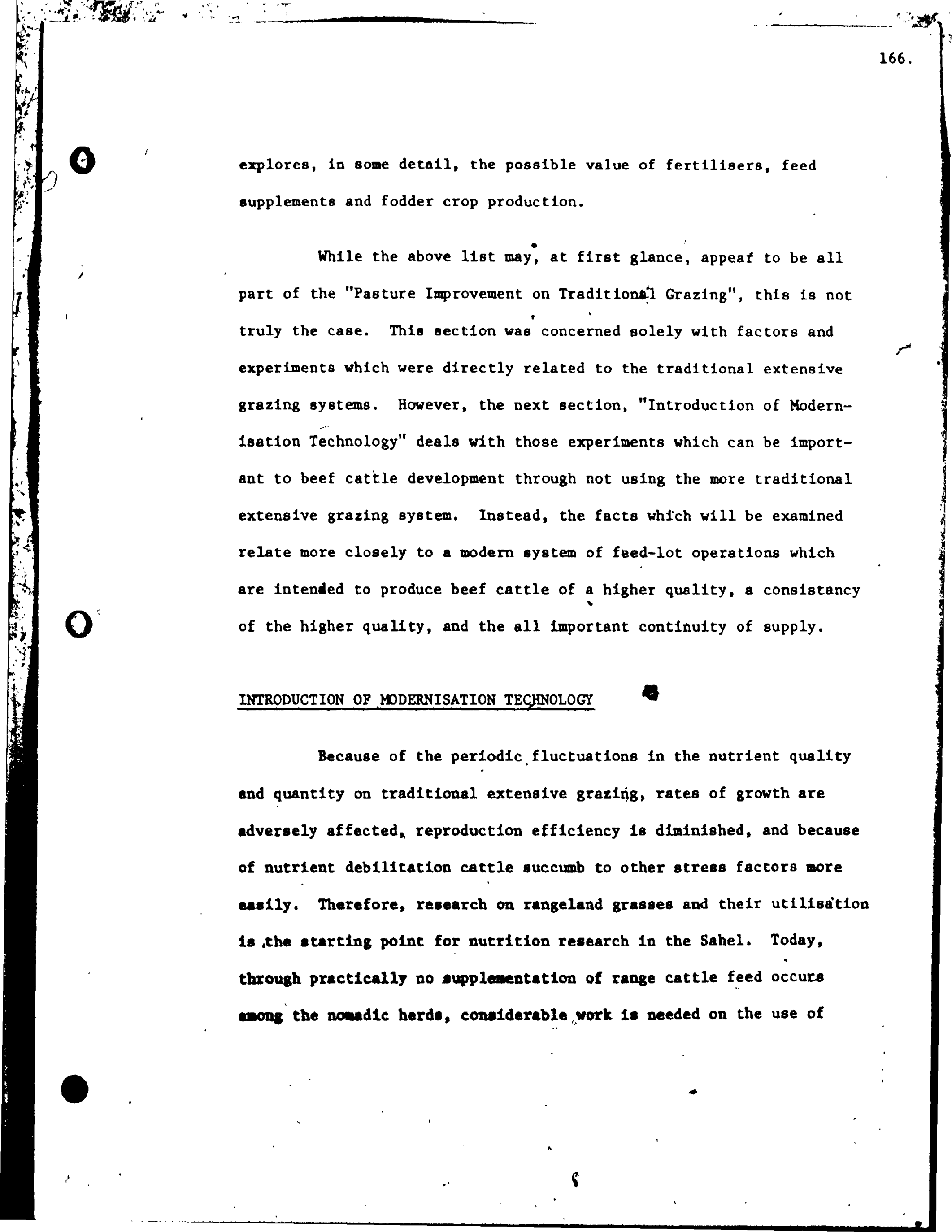


agricultural fett1lisers, cultivated forage and cattle feed supplements. Th1s section will detall the research undertaken on these areas where the results could be used in the Sahel.

a. Pert1lisers: Modern agricultural systems have placed great otock in the success of fert1lisers since nitrogen (N) 1s the main element of growth. Almost the entíre Sahel has an outstanding soll-nutrient deficlency in $N{ }^{36}$ a fact very noticable durlng the severe dry season due to the practice of burning the grasses" exy dry season. The consequence of this burning is that all the $N$ in the top growth of the grass is returned to the air, with only the mineral ash belng returned to the soll. Smith's experiments in 1961 and $1964,37$. "... found that when 40 lbs of $N$ was applied three times during the growing seas on each $l b$ of $N$ fertiliser increas ed the dry matter production by 23 los and the crude protein by $3 \mathrm{lbs}$......they grazed. their pas tures with dairy heifers, and the response per $l b$ of $N$ applied "was....2.5 to 3 lbo liveweight gain in the heifers."

West's 1959 experimenț ${ }^{38}$ obtained livewe1ght gains of gteers of 90 1bs per acre over a 150 day grazing season on natural pastures, and 150 lbs if 80 lbs of $N$ fert1liser were given, but 440 1be if this amount of $N$ were given on improved pastures.

The maln point about $N$ fertilisers was that the protein content of the dry season growth was ralsed so that when growth ceased, the sanding dry fodder had a higher proteln content. Th1s aspect was 111 ustrated by the research of Vicente-Chander and Figarella 39. on Guines Grass in Puerto Rico. 
The1r research also shöwed that $N$ fertiliser applications above $100 \mathrm{lbs}$ per acre did not increase the dry matter yield, and that although there was an increased protein yleld, there were clearly decreasing returns to scale as the application of $N$ was increased. 40 .

Phosphate fertilisers (P) would seem to be almost as important as the $N$ fertilisers fust mentioned, but the phosphate respones are not so clear-cut as $\mathrm{N}$. This 18 because $\mathrm{P}$ fertilisers are rendered insoluble when they enter the solls. Thus, as $P$ fertllisers are spread over the soll surface they become concent-" rated in the top few Inches of the 8011 and can only be taken up by plants when the surface soll is molst, therefore being only benefictal to wet season growth. 41 .

Norman's experimentation 42 . showed that while cattle responded favourably to a $P$ supplement in the wet season (confirmation of the Insolubility of $P$ ), but that $P$ supplement:1n the dry season does not prevent heavy losses in welght. His later research results published in 1965,43 . Indicated that while $\mathrm{N}$ is an overrlding deficlency in the dry season, $P$ is also a limiting factor.

All research reports which were examined gave positive, results for the tests carried out using $P$ fertiliser, thereby leaving . 11ttle doubt that both, $N$ and $P$ fert1lisers must form an important part of the chapter vIII bofef strategy. However, while some in-. dications have been given concerning the quantitles of $N$ which 


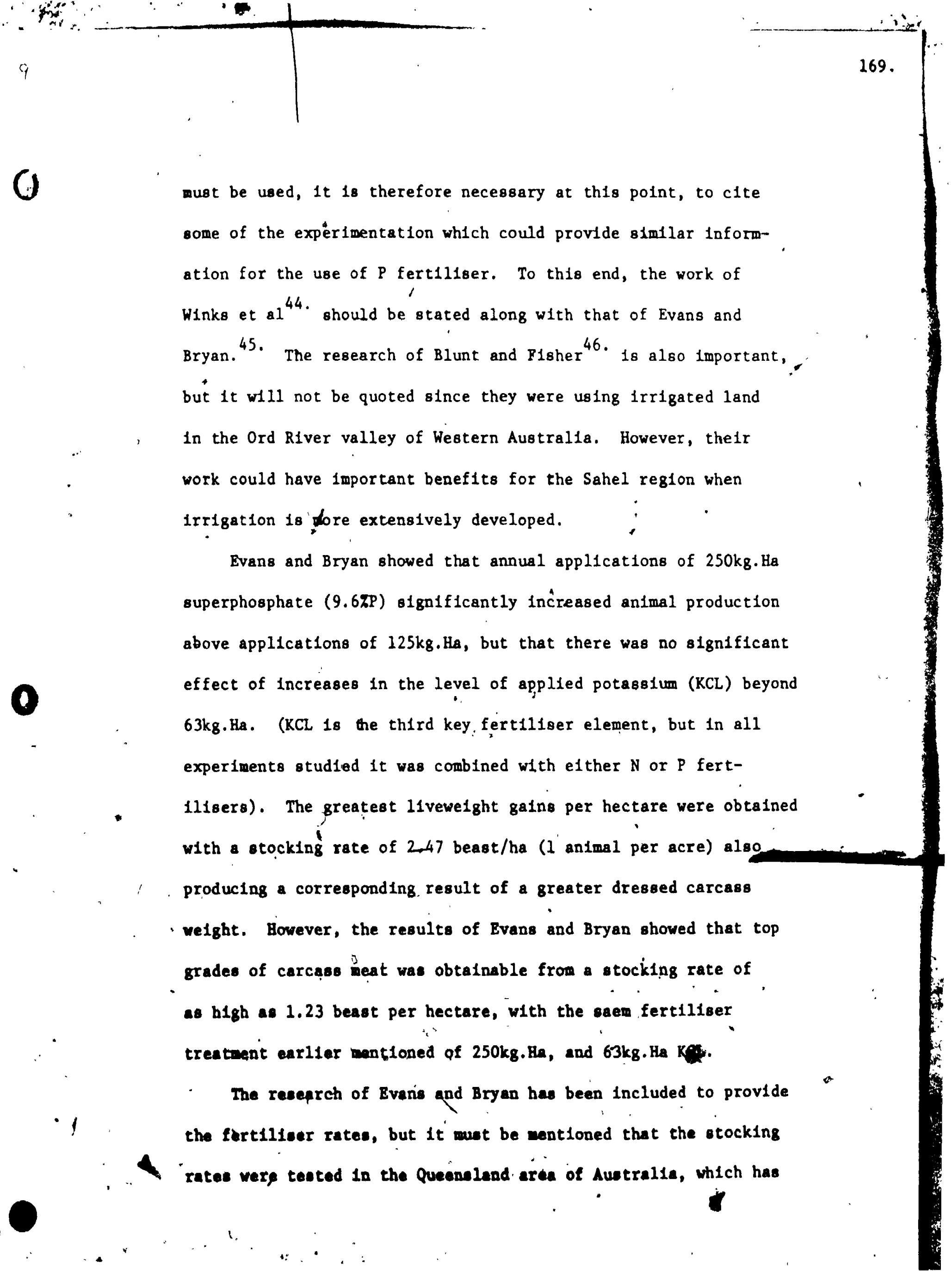


factor really becomes a pure question of the economics. The following example, from tests in Botswana, ${ }^{47}$ w11 provide some Indication of the basic economic calculations:

\section{Test acre with fert111ser}

$\underline{\operatorname{Costs}}$

$$
\begin{aligned}
& 100 \text { 1bs nitrogen fert1liser/acre }=R .1 .93 \\
& 100 \text { lbs phosphate fert1liser/acre }=\frac{R .1 .55}{3.48}
\end{aligned}
$$

Revenue Yleld of sorghum 7.1 bags*/acre e R. $3.5=R .24 .65$

$$
\star b_{\text {bg }}=2001 \mathrm{bs} \text {. }
$$

Net Return - Revenue less Costs

$$
\text { R. } 24.65-3.48
$$

- R. 21.17

Test acre without fert1liser

Revenue Yield of sorghum 4.6 bags/acre R. $3.5=$ R. 16.10

Net Revenue Increase through fertiliser use

Net Revenue w1th fert1liser - Net Revenue w1thout fert1liser

$$
\begin{aligned}
21.17 & -16.10 \\
& =\operatorname{R} \underline{5.07}(31 \% \text { increase in Net Rev. })^{2}
\end{aligned}
$$

Wh1le the use of fertilisers must be an economic question, much Information has beet mentioned here which wll be incorporated into the strategy. If the use of fertiliser becomes part of a Government Plan, then the economlcs of fertillser useage must also be balanced with the ${ }^{3}$ development of fodder crops, as part of an Agricultural Development Policy. It may eventually transpire that the returns for the final beef product can only fustify development of fodder crop production without the use of fertilisers. Hence, the next section desls with the question of fodder crops. 


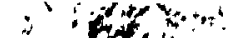

$\therefore 9 t+n^{4}$

b. Cattle Peeds:

"The whole technology of fodder conservation will demand study in relation to the requirements of the animal. There is only limited experience in the tropics upon which to draw and it will not be wise to rely wholly on work done outs ide." 48.

While information will be required by the Sahel region beef cattle producers on the management of pasturelands, fertility treatments and the techniques of plant cultivation, information w11 also be required on fodder conservation, the grazing methods to achleve this and on the harvesting and storage of conserved

- feeds. To reduce, or eliminate cattle weight loss during the non-growing season it is necessary to increase the amount of feed eaten. Th1s 18 where fodder crops and feed supplements can play ap important role in the development strategy.

The practical difficulties of making hay or slllage must be overcome, but it is unfortunately in this regard that a firm method cannot be proposed in this paper. Nonetheless, some of the research on fodder crops to be cited in this section w111 Indicate some of the potential.

The simplistic calculation show under "Fert1lisers" gave some Indication of the value of fert1liser use for fodder crop production, but 1t did not provide the whole story. Though fert 111sere can substantially Increase crop ylelds during the growing season (wet ceason); mantgemant, soll factors and rainfall actully set many lintte on cattle stocking rates. The main 11mitattor fo the number of andmals per untt is really determined 
by the bottle-neck of drought unless fodder 1s consumed for dry season feed.

The PAO, In 1970, publ1shed the "Better Parming Serfes" wherein volume 12 set forth an easy method for the preparation and storage of sillage and hay. It would seem that this FAO recommendation hạs also proved successful in some native v1llages of Ma11. ${ }^{49}$. Temanson, a Peace Corps volunteer, operated a successful self-help project wth the aim of 140 pit81108 being completed by September 1974. H1s project was 1deal for the Sahel because no expensive equipment or spectal technology was needed.

An important plus for the beef cattle industry. 1s that this type of self-help s1lo programe is not directed at the nomads of the Sahel. Instead, it is almed at the sedentary farmers who would be responsible for the important fodder crop production link of the beef Industry.

There are undoubtedly other methods for the preparation and stprage of fodder being used in other parts of the World, particularly in East Afrlca, which could be useful to the Sahel. However, the PAO system is cost free, a key factor when such a large proportion of development finance must come from external sources.

What of the crope that may be consldered for fodder and which could be produced in the sahel? 
Such a list for consideration must seriously consider

Townsville Lucerne, both for grazing and slllage; maize, 50 . which exceeds all other crops in the average ylelds of dry mater and of digestible nutrients per acre; 51 sorghum, 52 . wh1ch makes good palatable sillage if ensiled when the seeds are hard and ripe. 53 . While Lucerne legumes, malze and sorghum appear to have been the most researched, and therefore the most widely used as dry season fodder, this is possibly because, at present, they may be considered the most readily avallable. However, there are several other crops which have proven successful elsewhere, particularly in East Africa, but these other crops require slightly more sophisticated preparation than do the three already mentioned. Nevertheless, they w11 be 11 sted here, wh the suggestion being made in chapter VIII, that their development be given serious consideration, since they would seem vital to a continfous supply of lmproved and consistant quality beef. These crops are millet, groundnut 011 meal and cottonseed meal, and they will be considered indiv1dually after maize and sorghum.

(1) Fodder Crops:

(a) Malze: Malze 18 grown in flve of the Sahel countifes, . the exception being Chad. It has generally been regarded as' a product that wouldmalnly be consumed by the Producers, or old in the towin. High yield maize ceeds are belnt developed (54) whtch in turn should reduce the per bushel cost. The lower cost, combined wth Increased ylelds and the higher meat prices, may Justify the use of mise as a complementary feed for cattle. 
(b) Sorghum: As produced in Africa, has been cultivated for centurles in the Sahel region. Like maize, the PAO guggests that further research must be undertakef (55) particularly aimed at hybridizing.

(c) Millet: Excellent results have been obtalned in millet through the use of hybrides with which gains of 50-100\% have evolved (56). However, millet research must be continued because of its potential, since it is able to survive in areas of less than 500m annual rainfali, where sorghum virtually disappears. Millet is important also because, though it resembles malze, it has an appreciably higher pfotein value than maize (57).

\section{(11) Peed Supplements:}

(a) Groundnut 011 Meal and Cake provides a feed supplement which is very high'in protein and it also is well liked by cattle (58). The total digestible nutrlents can vary considerably according to whether oll meal, or ofl cake 18 used, and this in turn is a reflection of the extraction process.

(b) Cottonseed Meal or Cake 11ke groundnut or cake, has a varied total digestible nutrient percentage according to the extraction processed used. Cottonseed extract has a very satisfactory protein level and 18 a good feed supplement for cattle. In addition; cottonseed is one of the richest feeds in phosporus, containing in excess of 17 of the mineral (59).

The above listed cattle feed supplements are by no means the only fodder supplements, but they are of h1gh protein value, having good cattle acceptability and are readily ava1lable throughout the Sahel region. However, there are two other supplements which have been proven to be very beneficlal to cattle on feed-lots; molesses, which ts not locally produced In the Sahel (except for in Senegal) and would therefore have to be 1pperted at a cost; urea, which can be producd throughout the Sahel region. 
(c) Molasses 18 a by-product in the manufacture of sugar (60) from sugar-cane, or sugar-beet. It is well liked by cattle such that a small amount may be used to induce atock to eat poor quality s1llage. However, for this purpose it is often mixed with urea.

(d) Ureas 18 a simple organic compound with a high nitrogen content. It is widely used in Rhodesia and Kenya for the molntenance and fattening of beef cattle in feedlot operations. Th1s 18 particularly valuable because urea can supply up to $50 z$ of the proteln requirements (61).

Molasse8, urea, malze sillage and cottonseed cake have proven successful when fed to cattle as a dietary supplement, both in Kenya at the Kenya Beef Industry Development Project ${ }^{62}$ and the b18 Cuban feed-1ot ${ }^{63}$. in Camaquey Province.

In the Cuban feed-1ot of 10,000 head, there was a da1ly weight gain 1ncrease of over 105\%, using a molasses based diet, when compared to the more traditional forage based diet. However, In any strategy using molasses, the work of Morrison 64 . must be remembered when he suggested,

"...the maximum limit of molasses in the diet should be 108, since at the higher levels... its feeding value could be expected to decline."

In the Renya feed-lot experiment the cattle were on a ration composition of 52.87 maize grain, 33.47 ma1ze sillage, 11.17 of . 47 urea wh molssses and 2.77 cottonseed cakes. The high energy feed gave increased yields of edible carcass meat between $30 \%$ and 507 af ter only 10 weeks in the feed-1ot. 


\section{CATTLE DISEASE}

In chapter $v$, 'health barriers' were shown as being a major hurdle wh1ch the Sahel countries must overcome if they are to successfully develop a beef cattle 1ndustry. Though these health barriers were considered in regards to beef being exported from the Sahel to Europe, control of the diseases makes good economic sence, since they impose heavy burdens on the 1ndustry. The diseases and parasites cause death, debilitation condemation, disruption of market movement, and generally add to the cost of production.

Because of the1r overwhelming importance, disease problems have been given priority attention in the past and can be considered as a major impediment to expanding beef production. Really, disease research and the subsequent disease control is an International goal, since áll continents are affected to some degree by the same catastrophic infections such as trypanosom1as1s, contaglous bovine pleuropneumonia, rinderpest and foot-andmouth disease.

Perhaps the most important organdzation specialising In these diseases for African Ifvestock is the Inter-African Bureau for Bplzootic Disease (IBED). This organization has been undertaking a setematic quarterly collection of reports from twenty covernments 65 . south of the sahara. Though the IBBD has been collecting information 


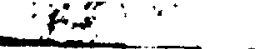


a. Trypanosomias18: Though a major disease in Africa, only In equatorial Africa does it constitute a major obstacle to beef production. Th1s is because the equatorlal climate is highly condusive to the tse-tse fly breed which is the Insect vector of trypanosomiasis. In the Sahel region it is primartly a camel affecting disease, ${ }^{69}$. though 1 t does occur in the southern areas of the Sahel countries where the ralnfall is higher. Some cattle breeds of the Sahel are resistant to the disease (see next section, "Cattle Breeds"), particularly the humpless cattle of West, although some other zëbu breeds are hfghly susceptable, thwo contracting the disease when belng exported south on-the-hoof. While presently there is no practical method of immunization, 70 . detection and treatment may be considered both a curative and a prophylactic procedure. Many organizations are Involved in tryIng to combat this dfsease in many parts of the World, including the new ${ }^{71}$. International Laboratory for Research on Animal Diseases (ILRAD) at Muguga, Kenya. However, whlle no Immunisation 1e presently possible, the best method of eradication really should be improved cattie management combined wth the Improved breeding of trypanosomiasis-tolerant cattle.

b. Contagious Bovine Pleuropneumonla: Research on this disease has been goling on for wany years, but the results of research 
and the application really stem from Joint Project $16,{ }^{72}$. which was set up by the Inter-African Bureau for Animal Health (IBAH). Research has Indicated the ability to control the disease as a result of early detection and subsequent imunisation through vaccination. Nevertheless, desplte these efforts Chad, Mal1 and Mauritania still seem to have a high Incidence, with N1ger and Upper Volta reflecting moderate success against the disease through their quarantine programmes.

c. Rinderpest: This is another highly contaglous cattle disease. Though it has been reasonably well controlled in West Africa ${ }^{73}$. since the establishment of Jo1nt Project 15, 74 . there is st111 a high incidence in, Mauritania, ${ }^{75}$ thus suggesting the progress of vacclination, quarantine and slaughter have been more successful In countries other than Mauritania. It should be noted that the programte of Senegal has been so auccessful that there has not been a reported case of rinderpest since 1968. ${ }^{76}$ clearly, therefore, rinderpest 18 well on the way to becoming a disease of the past so long as work continues for improved methods of detection and control, and the herd owners can be taught Improved management methods.

d. Foot-and-Youth: Th1s disease has been the scourage of Europe for many years and even today there are st11l perlodic outbreaks. 
Thus the 'health barriers' are designed very specifically to prevent the return of this disease to the European countries. While the disease is hard to eradicate completely 1t can be done through' the implementation of vaccination, 77 . quarantine regulations and the control of all anfmal movement. Th1s 'movement' is particularly 1mportant at frontlers for countrles like Chad, Mall and N̈1ger who experience a considerable illegal export trade of cattle-on-the-hoof. According to the FAO Disease Yearbook, with the exceptIon of Senegal, ${ }^{78}$ all countries of the Sahel st111 have footand-mouth even though most have already tried to fmplement some quarantine regulations with varying degrees of success.

Mention of these four diseases has been important because the outbreak of any one of them could, if undetected, destroy the beef Industry of a large part of the Sahel.- Even small outbreaks could be cruclal to the 'continuity' of supply' (see chapter V) 1 and therefore the strategy w11 have to be very much concerned wth the control and eradication of these diseases discussed and others, such as anthrax and ochinoconossis-hydalldous, Clearly, all the animal disease research facilities must represent a considerable resource in the future development of a beef cattle industry. Though $1 \mathrm{t}$ is expected that the Governments of the Sahel will continue to assume a large share of the costs involved for the control. 
In most of the developing countries certain breeds of types of cattle have evolved as a result of natural selection. Many of these animals possess extremely desdrable characteristics such as disease resistance, heat tolerance and the abflity to convey coarse feeds and fodder. However, the lack of systematic selection, the retention of all males and the indiscriminate breeding has given rise to many characteristics of questionable value. In reçent years a tendency to import European ór American stock into. Africa has resulted in a dilution of the characterfatics of the indigenous animal.

\section{Unfortunately, vey little work seem to have been carried} tout on the breeding of cattle the sahel for beef putposes. This is probably due to the fact that most cattle in the region are run by the nomadic tribes.

"Prior to the independence" of the Sahel countries, the French Colonial Administration established several Centres des Rechejches Agronomiques in what was then called French Weat Africa. But, these Centres were developed primarily to assiot tbat faxpers by conducting research into Improved agricultural production. However, the Centre des Recherches Agronomiques at Bambey. Senegal, became involved in some cattle cross-breeding though the work waskinged towards the development of a satisfactory draft animal and delry cow, not beef. $\rightarrow$." 
factors which militated against the division of

the cattle population... into clearly defined breeds" since much of the Sahel is occupied by "...cattle which are intermediate between one breed and another."

a. N'Dama!2. A popular beast in Senegal, MaI1, Upper Volta and Niger because it is trypanosomiasis resistant and will produce excellent quality meat on relatively poor savannah grazing. The average weight at maturity is $350 \mathrm{~kg}$ yielding $54-55 \%$ dressed weight on good cattle.

b. West African Shorthorns? 3 . While not a native of the sahel region, this animal can thrive in the region despite the longer dry season and the rather higher temperatures than their normal habitat, the coastal countrles. The Shorthorn ylelds a good quality beef carcass of $55 \%$ dressed welght from an average laughter welght of $200-300 \mathrm{~kg}$.

c. Maure?4. The Maure 18 well known in both Mall and Mauritania. The Maure zebug are slaughtered for meat at about 4-5 years of age with a sifewe1ght of about $350 \mathrm{~kg}$, and a dressed percentage of $45-50 x$.

d. Araouak?5. It is mainly a milk producer in Niger, being regarded a mat procucer of only average quality. Hence, it can be disregarded for the beef industry.

- Sokoto?6. "This animal is comed malnly by the Fulant in Miger 
18 well adapted to the shore grasses of the Lake Chad area but they do not thrive so well in dry, sandy reglons.

The aforementioned types of cattle are all indigenous to the Sahel, and thus they possess a heat-tolerance combined with an abllity to forage successfully during the long dry season. Since work on cross-breeding in East Africa showed that crosses with the exot1c breeds led to a loss of these indigenous abliftles, the 1deal would therefore, seem to point to the cross-breeding of zebu strains. While little work on zebu-crosses seems to have been carrled out, a start has been made at Flanga, Chad. At the Fianga Experimental Station, the N'Dama has been crossed with the West African Shorthorn in the hopes of produc1ng an improved well-acclimated type of beef antmal. The result, thus far, has been a larger animal with better beef conformation than either parent type, but no more information is avallable at this time.

\section{SUMMARY}

Whyle this chapter would seem very long and detalled, of issity it had to be 80 . Despite 1ts length, the chapter is really only a sumary of the more important research that has been carried out In other parts of the World but which could prove beneficial to the sqhel.

In the latter part of thle chapter cattle types were 11 sted 
but no research results were shown. The reason 18 that there is little cross-breeding research, thus far, which could be transferred to the Sahel region. Therefore, the breeds have been detalled with a view to incorporating this information into the atrategy of the next chapter.

It should be polnted out that there has been other research undertaken which could help a. Sahel beef cattle industry; however, the results selected for th \pm 8 chapter have been because they w111 be incorporated into the beef lindustry development scheme which can now be proposed. 


\section{FOOTNOTES}

1. D.W. Rob1nson and R. Sageman, "The nutritive value of some pasture species in north-western Australia during the late dry season", In the Australian Journal of Experimental Agriculture and Animal Husbandry (Aus. J. of Exp. A8. \& A.H.) Vol. 7, 1967. p.533.

2. D.W. Robinson and R. Sageman, "The dominant species in the sandy 8011 in the north-eastern Kimberley area", Ib1d., p.534

3. W. Davies and C.L. Sk1dmore, "Problems of Pasture Improvement" In Davies and Sk1dmore edition of Tropical Pastures, London, 1966. P. 22 .

4. Types and Breeds of Afrtcan Cattle published by the FAO, Rome, 1957.

A study of the zebu cows 11sted suggested that they calve for the first time between 3.5 to 5 years of age; approximately double the time for the cattle of a developed economy. Calving intervals are double again, being normally about 18-24 months. Bulls are not used for service before 2 years of age, and often not before 3 years. Lactations vary considerable from a low of 4 to a maximum of 8 .

5. P.M. Ahn, West African So118, published by the Oxford University Pres8, 1970. P.154.

6. Ib1d., P. 242 .

7. J.H. Topps, "Urea or bluret supplements to low protein grazing In Africa", published in World Animal Review, Vol. 3, by the : FAO, 1972. P.14.

8. M.J.T. Norman, "The Effect of Burning and Seasonal Rainfall on Native Pastures at Katherine, N.T.", In the Aus. J. of Exp. Ag. A.H., Vo1. 19, 1969. p.295.

9. Sulphur is an essentlal element which 18 particularly relevant to protein synthesis.

10. P.M. Ahn, op. c1t., P.237

11. M.J.T. Norman, op. c1t., p.295.

12. Ib1d., P.296 
13. Bi-ennial menalifgevery two years; not to be confused with bi-annual meaning twice annually.

14. M.J.T. Norman, 오. c1t., P.296.

15. The Evaluation of So1l Résources in West Africa - A Regional Sem1nar at Kumas1, Ghana, 14-19 Dec. 1970. Reported by FAO and UNDP.

16. Th1s 18 not the f1rst soll map of Hest Africa since IfaN, ORSTOM and CCTA (Comission of Technical Cooperation in Africa), have been actively producling soll surveys of limited areas for - long t1me. However, this new map promises to be the most comprehensive and useful for inter-regional development.

17. D.W. Roblnson and R. Sageman, op.c1t., p.533.

18. Ibid., p.535

19. Ibld., P. 538

20. Ibid., P.535

21. W. Davies and C.L. Skidmore, op.c1t., p. 26.

22. Under "So1ls" 1 was mentioned that $N$ was an element in which tropical solls are particularly low and also lose rapidly; but It is an element which must be present if high dry-matter and high protein ylelds are to be obtalned from pastures on such oolla. Owing to the-generally low economic level of the Sahel and the comparatively high cost of fertlisers, the principle supply of $N$ by legumes becomes a matter of great Importance, eince $f$ flxation by legumes 18 considerably higher than in 8rase.

23. M.J.T. Norman and G.A. Stewart, "Complementary grazIng of nat Ive. pastures and tanding Townovilie Lucerne in the dry season at Katherine, N.T.", in the Aus. J. of Exp. A8. \& A.H. Vol IT, 1967. P.225.

24. Ibld., $P .227$

25. R.N. Wesley-Smith, "Llvewe1ght galns of thorthorn steers on natfve and Improved pastures at Adelalde RIver. Northern Territorien", In the Aue. J. of Bxp. Ar. A.H. Vol. A12. 1972. p.566. 
26. H.P. Miller, "The effect of pre-treatment of native pasture and sowing rates. on establishment of Townaville Lucerne on Tippera clay loam at Kather1ne, N.T.", In the Aus. J. or Exp. As. \& A.H. Vol. 17. 1967. p.515.

27. Ibid., P.516.

28. Itd.. 0.517

29. H.P. M11ler, op. c1t., P.571,

"...approximately $20 \mathrm{~mm}$ of rain 18 reckoned sufficlent to produce seedilngs from an existing Townoville Lucerne atyle pasture, and follow-up rains are needed for further growth."

30. H.P. Miller, op. c1t., p.517.

31. J. Phillips, The deyelopment of agriculture and foresfry in the Trop1cs - Patterns, Problems and Promises, London, 1961. p.172.

32. J. Griffiths Davies and A.G. Eyles, "Communication of Results", In Davies and Skidmore, op.c1t., p.153.

33. D.W. Robinson and R. Sageman, op. c1t., p.5331

34. A.M. Morgan Rees, "The Economics of Tropical Grassland", In Davies and Sk1dwore, op.c1t., p.168.

35. Ib1d., P.170

"...applying varying levels of nitrogen and basic level of potash, carrying capacity was Increased by 0.5 beasts per acre for every three hundredweight of nitorgen fertiilaer applled."

36. J.H. Topps, op. c1t., p.14.

37. 0. West, "Pasture 1mprovement in the higher rainfall regions of Southern Rhodesia", In the Rhodesia Asficulture Journal, No. 53, 1956. P.439.

38. IbId., P.439.

39: I.W. Ruseell, "So11, and So11 Zert111ty". In Davies and Sk1dmore, op. c1t.. P.42. 
40. A.M. Morgan Rees, op. c1t., p.170.

"...work carrled out by Motta (1961) in Jamaica on Pangola 8 rass confirms the diminishing returns though he indicated the base level should be 3 cwt per acre of nitrogenous fertiliser but that carrying capacities were increased by 0.5 beast per acre."

41. E.W. Russe11, op. c1t., P.43.

42. M.J.T. Norman, "Dry season protein and energy supplements for beef cattle on native pastures at Katherlne, N.T.", In the Aus. J. of Exp. Ag. \& A.H. Vol. 3, 1963, p.280.

43. M.J.T. Norman, "Seasonal performance of beef cattle on native pastures at Katherine, N.T.", In the Aus. J. of Exp. Ag. \& A.H. Vol. \#5, 1965. p.227.

44. L. Links, F.C. Lamberth, K.W. Moir, and P.M. Pepper, "Effects of stocking rate and fertiliser on the performance of steers grazing Townsville style-based pasture in north Queensland", In the Aus. J. or Exp. AB. \& A.H. Vol. 14, 1974, p.146.

45. T.R. Evans and W.W. Bryan, "Llvewelght change and beef production", In the Aus. J. of Exp. Ag. \& A.H. Vol. 13, 1973, P.530.

46. C.G. Blunt and M.J. Fisher, "Production and utilisation of fodder and grain sorghum as forage for cattle in the Ord River valley, Western Australia", in the Aus. J. of Exp. Ag. \& A.H. Vol. \#13, 1973. P.234.

47. B.G. Level, "Agrlcultural Extenston In Botswana", In Development Studies 7 , 1970. P.57.

48. W. Dav1es and Sk1dmore, op. c1t., P.24.

49. "Land, Livestock and Lady Bugs", In War on Hlunger, Vol. \#VIII, No. 8, published by the Agency for International Development (AID), Washington, 1974. p.14.

50. Maize is avallable in the Sahel.

51. J.H. Topps, Animal Feede of the Pederation, published by the University College of Rhodesta, 1961. p.38.

52. Sorghum 1o readily avallable in the Sahel and it could be produced in comercial quantitien in the region, although the econonfet of 'comparative adventage' mate be an Important consideration. 
53. J.H. Topps, Animal Feeds of the Federation, op. c1t., p.40.

54. Indicative World Plan for Agricultural Development to 1975 and 1985, published by the FAO, Rome, 1968. p.170.

55. Ib1d., p.161.

56. Ibld., p.161.

57. J.H. Topps, Animal Feeds of the Federation, op.c1t., p.12.

58. Ib1d., P.15.

59. Ib1d., p.16.

60. Ibid., p.43.

61. Ib1d., P.44

62. M.J. Creek, "The Kenya Feedlot Project", In World Anlmal Revlew, Vol. 3. 1972. p.23.

63. T.R. Preston, "Fattening beef cattle on molasses in the tropics", in World Animal Review, Vol. \#1, 1972. p. 24

64. Ibid., P.24

65. AJ.E. Rouse, World Cattle Vol. II, Oklahoma, 1072. p. 283.

66. The IBED 18 not limited to cattle diseases but diseases affecting all antmal life.

67. These diseases can exercise a virtual itranglehold on the cattle Industry once into country, as has been the case in both the Unted Ringdon and France in recent years.

68. J.E. Rouse, op. c1t., P.283.

69. P. Finelle, "African AnImal Trypanosoniasis". In World Animal Review Vol. 17, 1973. p.2.

70. Ibld., p.4.

71. The proposal for the ILRAD was aubmitted May 1972 by a team comniestoned by the Rockefuller Poundation at the requeet of the African Livestock Sub-comittee of the Conaultative Group on International Agrfcultural Research. 
72. A project established by IBAH in the early 1960s for the research, control and eradication of contaglous bovine pleuropneumonia.

73. Thirteenth Annual Report, 1964, published by the Inter-African Bureau for Animal Health, p.9.

74. A project established by IBAH for the research, control and erad1cation of rinderpest.

75. An1mal Health Yearbook, 1972, published by FAO-NHO-OIE, Rome, 1973.

76. Ib1d.

77. Control by vaccintaition was first tried in Nigeria and Chad in 1963, but it should be noted that research on foot-and-mouth vaccines must be continued because the disease has several types of virus.

78. Senegal has had no reported case of foot-and-mouth since 1968.

79. J. Ph1111p8, Agriculture and Ecology in Africa, published by Faber \&aber, London, 1959, p.768. and in Etude sur la situation actuelle de 1'élevage dans les pays du Sahe 1 et des mesures de sauvegarde a envisager, published by the formission des Communautes Européenes, fevr1er 1974, p.219.

"The Djakore is the result of generations of 1nterbreeding between the Gobra and the N'Dama under controlled conditions."

80. J. Ph1ll1ps, op.c1t., p.769.

81. Types and Breeds of Cattle, published by the FAO, Rome, 1958, p.6.

82. Ib1d., p.118ff.

83. Ibld., P.130ff.

84. Ib1d., P.54ff.

85. Ibld., P.48ff.

86. Ib1d., P,81ff.

87. Ib1d., p.86ff.

88. Ib1d., p.139ff.

89. J. Ph1111pa, op. c1t., P.724. 
THE BEEF CATTLE DEVELOPMENT

2.

\section{INTRODUCTION}

The alms of the beef development strategy

(a) Long-term a1ms

(b) Intermediate afms

Ranch site selection

Development of grazing sections
(a) Pencing
(e) Forage production
(b) Grazing
(f) Forage management
(c) Stocking-rate
(8) Fodder production
(d) Water

The Herd
(a) Composition
(d) Mortality
(b) Breeding
(e) Slaughter
(c) Calving

The feedlot operation
(a) Location
(d) Water
(b) Construction
(e) Feed types
(c) Stock capacity
(f) Feed balance

The abattoir operation
(a) Location
(c) Markets
(b) Operation
(d) Benefits

Transportation modes
(a) Road
(c) Other modes of transport
(b) A1r

D1serse control

Boployment of Nomads

long Term possibilitles

(a) Addittonal Ranches

(b) Ranch expansion

(c) Feed-1ot addition 


\section{CHAPTER EIGHT}

THE BEEF CATTLE DEVELOPMENT

\section{STRATEGY}

\section{INTRODUCTION}

Different premises dictate different plans, and thus, at this polnt, it would be wise to set forth a brief list of the conditions which are belleved to presently exist in the Sahel and which form the bases of the Plan described in this chapter.

1. The potential for the establishment of a successful beef cattle industry does exist in the region.

2. The traditional cattle knowledge of the nomads can be integrated into a modern food chain system.

3. The nomads can be introduced into a system of modern education.

4. The vartous nomadic bands can work together despite tradtional hostilities.

5. The nomads and the Individual Governments of the Sahel countries would welcome beef development strategy.

\section{THE AIMS OP THE BEEF DEVELOPMENT STRATEGY}

Kodern management techniques suggest the use of two types of aims; long-term aims and intermedidte aims.

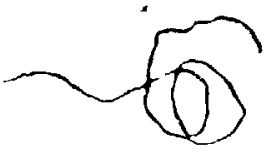


b. Intermediate alms: Though it is not unreasonable for the long-term objectives to be non-measurable, the same cannot be sald for the intermediate alms. These latter objectlves must be very specific and, therefore, quantifiable. Often these Intermediate aims will be established so that an annual review can be made as a means of assessing the progress of the profect towards the attainment of the long-term goals. Should these intermediate targets not be obtained at the required time, a good plan allows for a certaln flexibility so that corrective measures can be taken, although sometimes a slight revision of the long-term alms may be acceptable.

The Plan presented in this chapter utilises a number of measurable intermediate targets though not such that annual review of progress can be made of the total profect. This is mainly due to the nature of the profect. For example, the progress belng made on the construction of a hydro-electric plant can be accurately assessed annually. Unfortunately, this

Is not the case when dealing with livestock improvement, or a reduction in the calving interval for 18 months to 12 months. Hence, the Intermediate alms of this Plan are set up on the basis of a five-year interval. For addition, the Plan has a flexibility such that if the intermediate targets are out by one, or even two years, it will not be a mafor disaster since the long-term objectives are of a very broad nature. This additional flextbility is probably one of the most important aspects of any developwent plan for a developing country since 


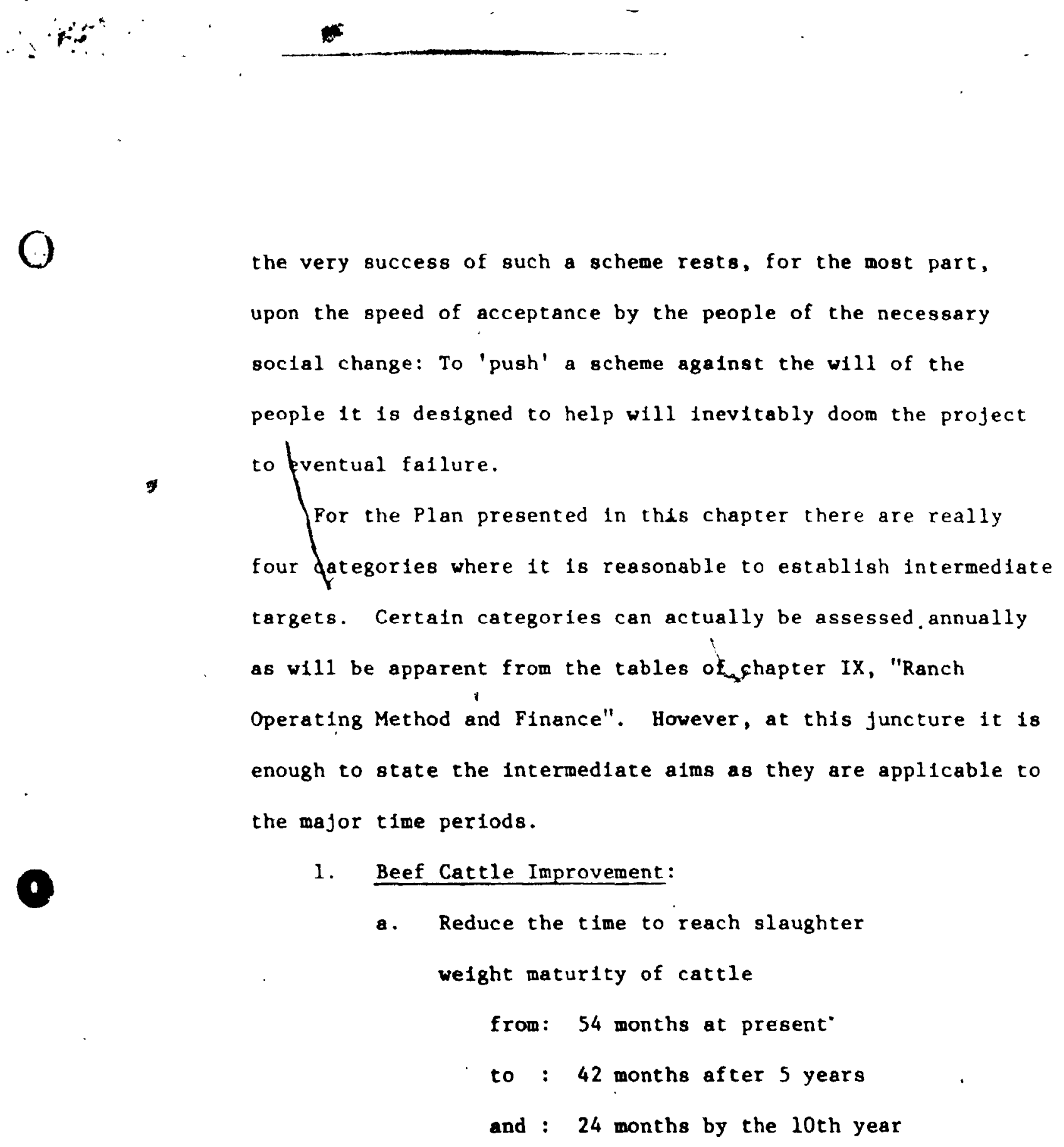

the very success of such a scheme rests, for the most part, the speed of acceptance by the people of the necessary change: To 'push' a scheme against the will of the people 1t ls designed to help will Inevitably doom the project four qategories where it is reasonable to establish intermediate targets. Certain categories can actually be assessed annually as will be apparent from the tables of chapter IX, "Ranch Operating Method and Finance". However, at this functure it is enough to state the intermediate aims as they are applicable to the major time periods.

1. Beef Cattle Improvement:

a. Reduce the time to reach slaughter weight maturity of cattle

from: 54 months at present ${ }^{\circ}$ and : 24 months by the 10th year

b. Reduce the periof of $1^{8 t}$ calving

frow: 42 months at present

to : 24 months by the $6^{\text {th }}$ year

c. Reduce the calving interval

from: 18 wonths at present

to : 12 months by the $5^{\text {th }}$ year

Onder Beef Cattle Improvement an additional target could be to Increase aubstantially the stock take-off rate which presently stands at posstbly as low as $7 x$. 1 . However, in order 
to accomplish this latter goal, the intermediate targets listed above must be obtained to develop a viable beef industry which would permit an increased take-off rate. Therefore, these intermediate alms have been incorporated to yield the calaculation for Table 8-2.

Judging by the wealth of research that has been undertaken concerning cattle development, it is reasonable to suggest that all three Intermediate targets can be met by improved health using better feeds and systems of disease control.

After health improvement measures, the Plan then only requires the addition of improved transportation and marketing to provide the profitability wh1ch will come with an increased take-off rate. However, all of this requires people and therefore employment targets must be considered.

\section{Employment of the Indigenous People}

a. End of $5^{\text {th }}$ year - all management positions to be filled by African.

- 900 nomadic families to be employed by each Ranch.

b. End of $10^{\text {th }}$ year $-2,100$ nomadic famflies to be

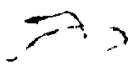
employed by each Ranch.

c. End of $15^{\text {th }}$ year $-4,500$ nomadic families to be employed by each Ranch.

d. End of $20^{\text {th }}$ year $-7,000$ nomadic familles to be employed by each Ranch. 
While the employment of nomadic families is listed as a target it really should be consldered more as a guide as to what would be desire. Such employment targets are attainable provided the cattle breeding goals are obtained and also provided the nomads are still prepared to accept the necessary accompanying social change. For chapter IX, table \#9-1 can be seen the detalls per annum with regard to the Ranch employment of nomadic families.

Obvlously, with the question of employment goes the Important question of wages. Hence, the next category of intermediate objectives concerns income distribution to the workers.

3. Annual Income per Nomadic Family

$$
\begin{aligned}
& \text { a. Years } 1 \text { - 5 - } \$ 200 \text { per, annum } \\
& 6-14-\$ 400 \text { per annum } \\
& 15-19-\$ 600 \text { per annum } \\
& 20 \text { plus - } \$ 600 \text { per annum plus a share of } \\
& \text { Ranch Profits }
\end{aligned}
$$

4. Annual Profit or Loss Objectives per Ranch

$$
\begin{gathered}
1^{\text {st }} \text { year - a lo8s of } \$ 1,202,870 \\
5^{\text {th }} \text { year - a 1088 of } \$ 1,379,077 \\
10^{\text {th }} \text { year - } 108 \text { of } \$ 1,673,795 \\
15^{\text {th }} \text { year - a profit of } \$ 687,755
\end{gathered}
$$


Having, thus far, listed both the long-term goals and the intermediate targets a brief description of the basic strategy proposed would be in order, after which the specific Plan detalls w11 be set forth.

The basic strategy is the development of a system of large Ranches. At the outset, one Ranch would be established in each of the Sahel countries. This dispersal across all the countries is designed to ensure at least a partial national balance of the benefits of beef industry development and an equitable distribution of the pre-development ald. Each Ranch would consist of approximately 400,000 hectares (1,544 sq. miles) with a starting herd of 12,00 beef cattle. The first year of each 2 . Ranch aperation will only benefit 400 families $(2,400$ people). However, by the tenth year, 2,500 families (15,000 people) will be infolved in the pasture areas. In addition, a further 200 families $(1,200$ people) would benefit from working in the Feed -lot, or the abattolr operation. (Both the feed-lot and the abattolr units would be part of the total Ranch complex being proposed in this chapter). Conceivably, by the twentfeth year, 7,000 families $(42,000$ people) could be directly employed by an expanded Ranch operation in, each country. There would also be many more thousands who could benefit indirectly through the economic 11nkage mechanisms (see Diagram 18-1: Economic L1nkages).

\section{RANCE SITE SBLECTION}

A Beef Cattle Planning Group (the Beef Cattle Group w11 be explained in chapter XI) In each country will have to 

work w1th the respective National Governments in order to select the approprlate sites. The following criteriawould be important in this regard:

a. The area must be located in the existing pastureland region.

b. The area must be sparsely populated and not privately owned.

c. Rainfall must be adequate to produce forage grass for livestock.

d. Underground water must be sufficient to supply approximately 400 permanent wells.

e. Land must be capable of producing year-round pastures .

f. S1te must have access to commercial routes. Or, the 4 development of such routes must be feasible.

The site will be set out to approximate thesayout shown on Map 16. Though the suggested layout may not always be practical, there are several benefits from such a design, not the lesst of which is controlled cattle movement to assist the disease control programme.

No costs are expected for land acquisition because the land can be deeded by the respective Governments.

\section{DEVELOPABNT OF GRAZING SECTIONS}

a. Fenc1ng: Bach Ranch will be totally enclosed by a six-stranded barbed wire fence, thereby producing the basis of a d1sease Free zone." Thls fence is intended, as far as possible, 
Map

IDEAL RANCH LAY-OUT

$(2,470 \mathrm{sq.Km} ; 400,000 \mathrm{Ha}$.

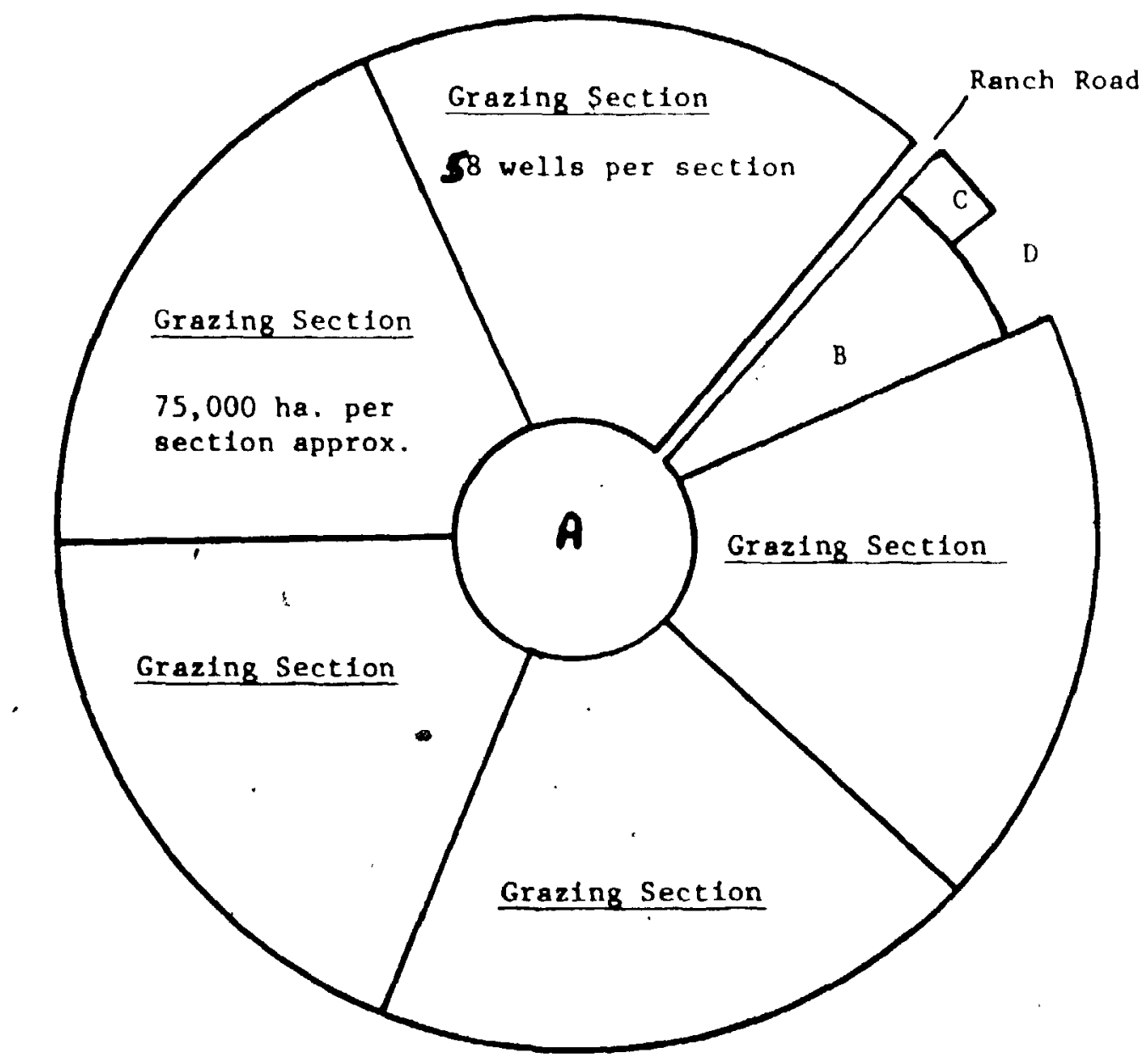

A. Ranch Headquarters area: Headquarters Bullding, dispensary, Ranch shops, 44 houses (key personne1).

B. Feed-Lot area (Including 6 barns).

C. Abattolr

D. Camuntty Area: 10 school houses, 16 homes (permanent staff),

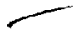
vlllage for familles of Ranch workers, Irrigated land area for nomadic fatullies now working on the Ranch.

NOTB: Area ' $D$ ' can be extended as the number of fantlies employed Increases.

Source: Developed by the author. 


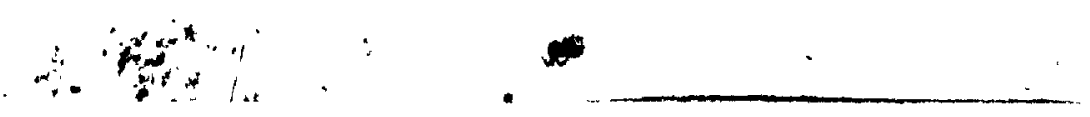

to prevent entry Into the controlled Ranch area by the wild animals and other nomads with their livestock. It will be necessary to patrol the boundary fence for maintenance and to protect it agalnat vandalism and trepassing. Costs of fence construction are shown in, Table $18-1$.

b. Graz1ng: Map 16, shows the Ranch stce as being divided into flve main grazing sections, each being approximately. 75,000 hectares $(185,250$ acres $)$. Each section w111 be grazed for a three months perfod using a system of rotation. Th1s will ensure that each section 18 grazed in a particular season only once in a five year period.

c. Stocking-Rate: The initial stocking-rate for the Ranches, proposed hereln w11l be approximately 27 hectares (65 acres) per antmal per year. This somewhat conservative stock-rate allows for the tyemendous soll deterioriation which has occured in recent years. However, by the tenth and twentieth years (aee Table 18-2: Estimated Stock Numbers), the carrying capacity of the pastureland could concelvably be improved to the extent that the stocking-rate could reach 3.16 ha. (9 acres) per aninal by the tenth year and even 1 ha. $(2.47$ acrea) per anteal by the twentieth year. Such a substantial improvement In pastureland can only be accomplisted by the int 8 rated development of water ouppliea, grazing control, forage and 
35

206.

$\mathrm{O}$

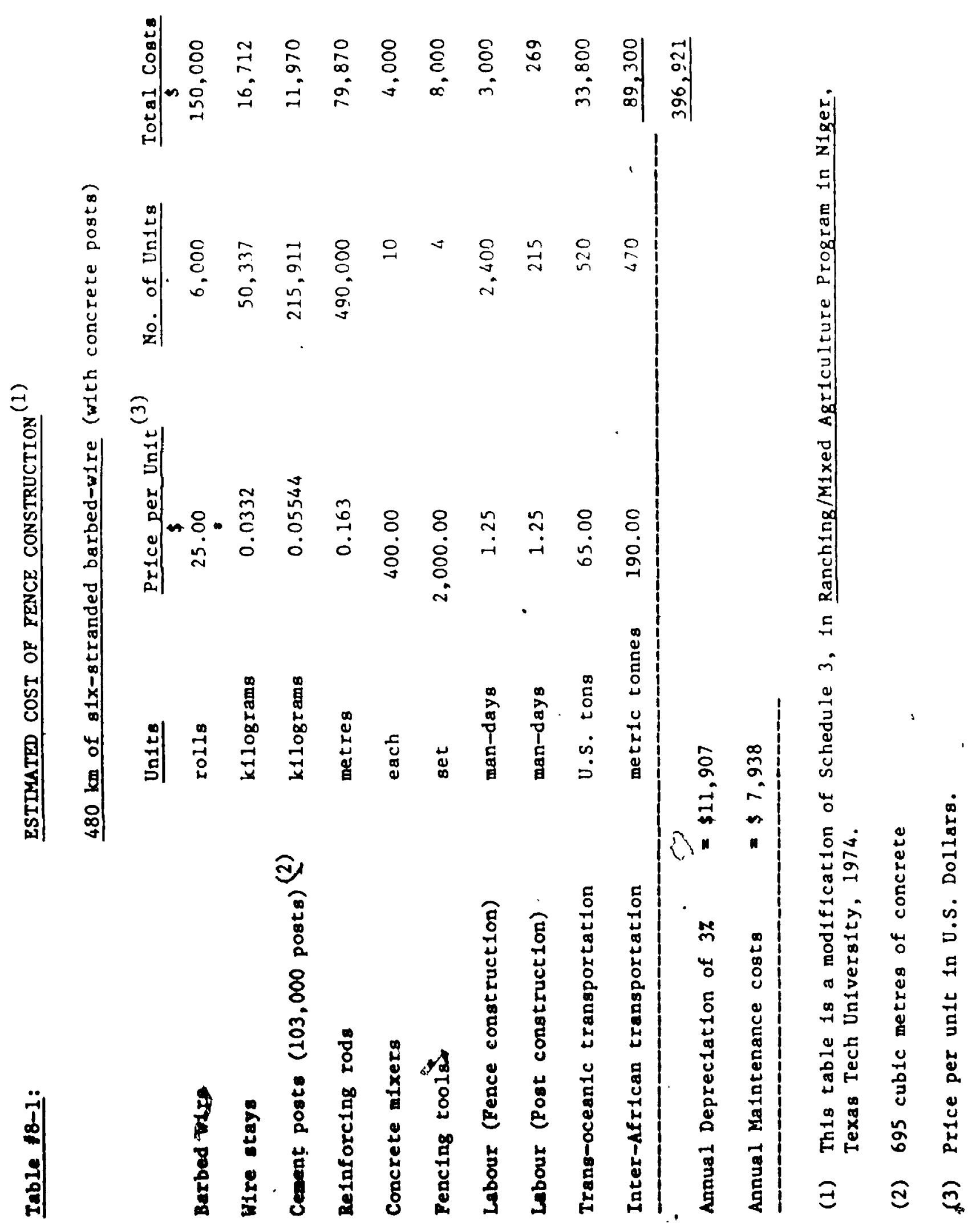




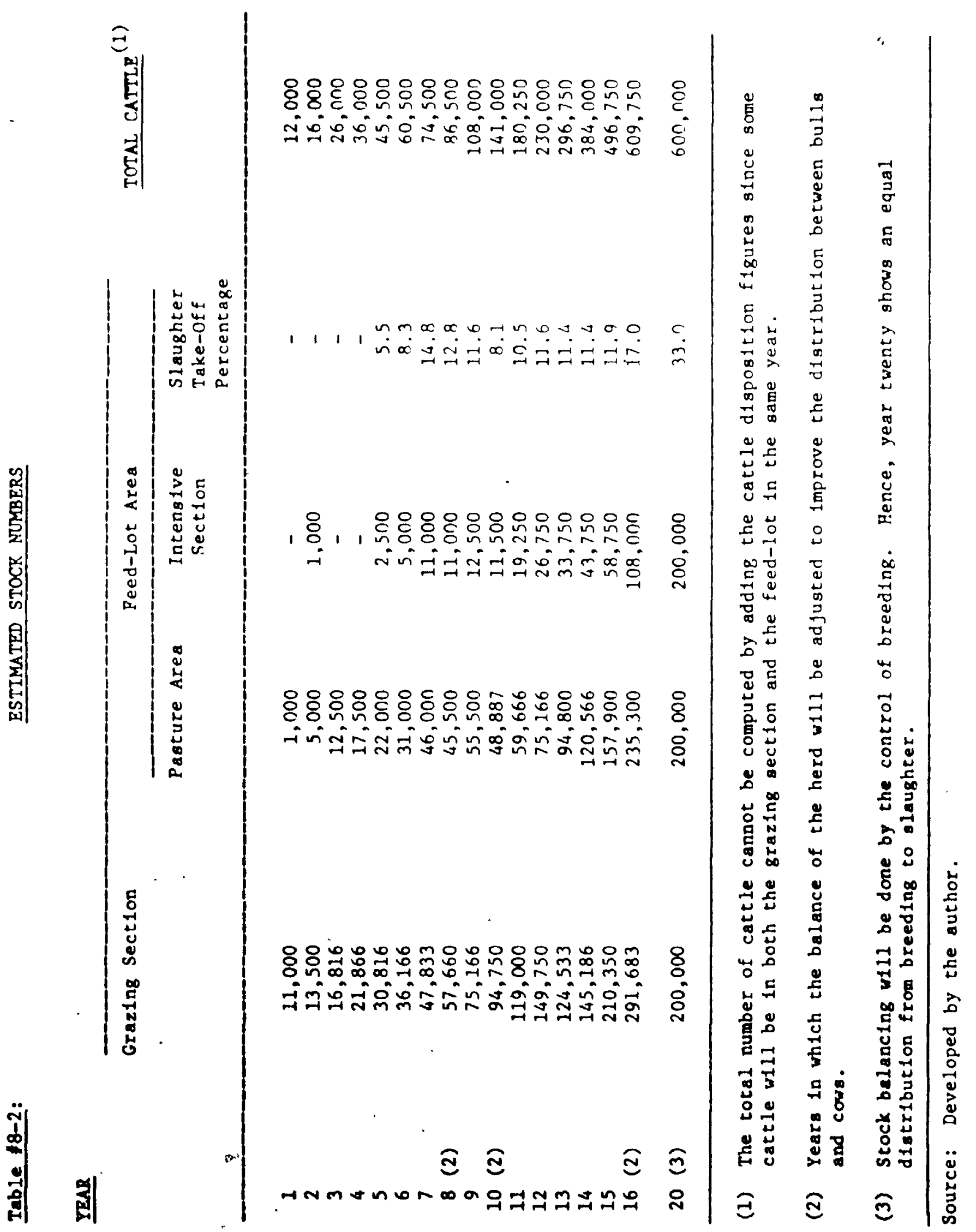


fodder cultivation.

d. Water: It 18 anticlpated that each animal will consume 50 11tres of water per day (based on Table 6-1: Average water consumption during the dry season). The spacing of water-polnts, one well per 1,300 ha., w1ll ensure that cattle do not have to walk more than $4 \mathrm{~km}$ to a source of water.

This should reduce the weight loss which presently occurs when cattle may have to walk over $30 \mathrm{~km}$ to iter. Fifty-eight wells are suggested for each grazing section and these cauld also be supplemented by cachement basins at certain times of the year. It will be necessary to construct additional wells outside the Ranch boundaries in order to minImlze trepsss violations by nomadic livestock herders not in1tially involved in the scheme.

Each well must be properly constructed using concrete and Installing drinking troughs to protect the water quality. The pump system used may infially be manual or animal tractIon, thereby reducing Ranch start-up costs. However, the fourth year will certalnly require higher pumping capacities due to the increase in stock numbers and thus other pump oystems, such as diesel or solar power, must be considered. Around certaln wells it will be important to develop a water storage system. Thus, there would be a reserve water supply avallable durting a prolonged drought when the water 
tables decline.

Well-ma1nenance crews w1ll be a necessary part of the Ranch operation and thus an added cost.' The est Imated costs and pumping capactity requirement are set forth in Table $8-3$.

e. Forage Production: The afrcraft seeding of Townsulle Lucerne (stylosanthes humflis HBK), a pasture legume, is worthy of strong consideration since it requires no soll preparation and appears to do well under similar climatic 6. conditions. Malze, millet and sorghum hybrids must also be considered.

Grass burning every two years is also recommended because this frequency was proved to produce the highest dry $\checkmark 8$. matter yleld per acre.

The application of superphosphate fertilisers to the pastureland is the third important factor for forage devel9. opment. While this may appear to be a high cost item, such an expenditure has proved to be justiffable in economic terms 10. In other areas of the World. Presently, fertllisers for the Sahel must be 1mported. But, with the large volumes which should be used in the Sahel for all forms of agriculture, fertiliser production in one of the Sahel countries could prove economically viable. Bach Ranch could use in excess of 100,000 wetric tonnes per annum, using $250 \mathrm{~kg} / \mathrm{ha}$. as 


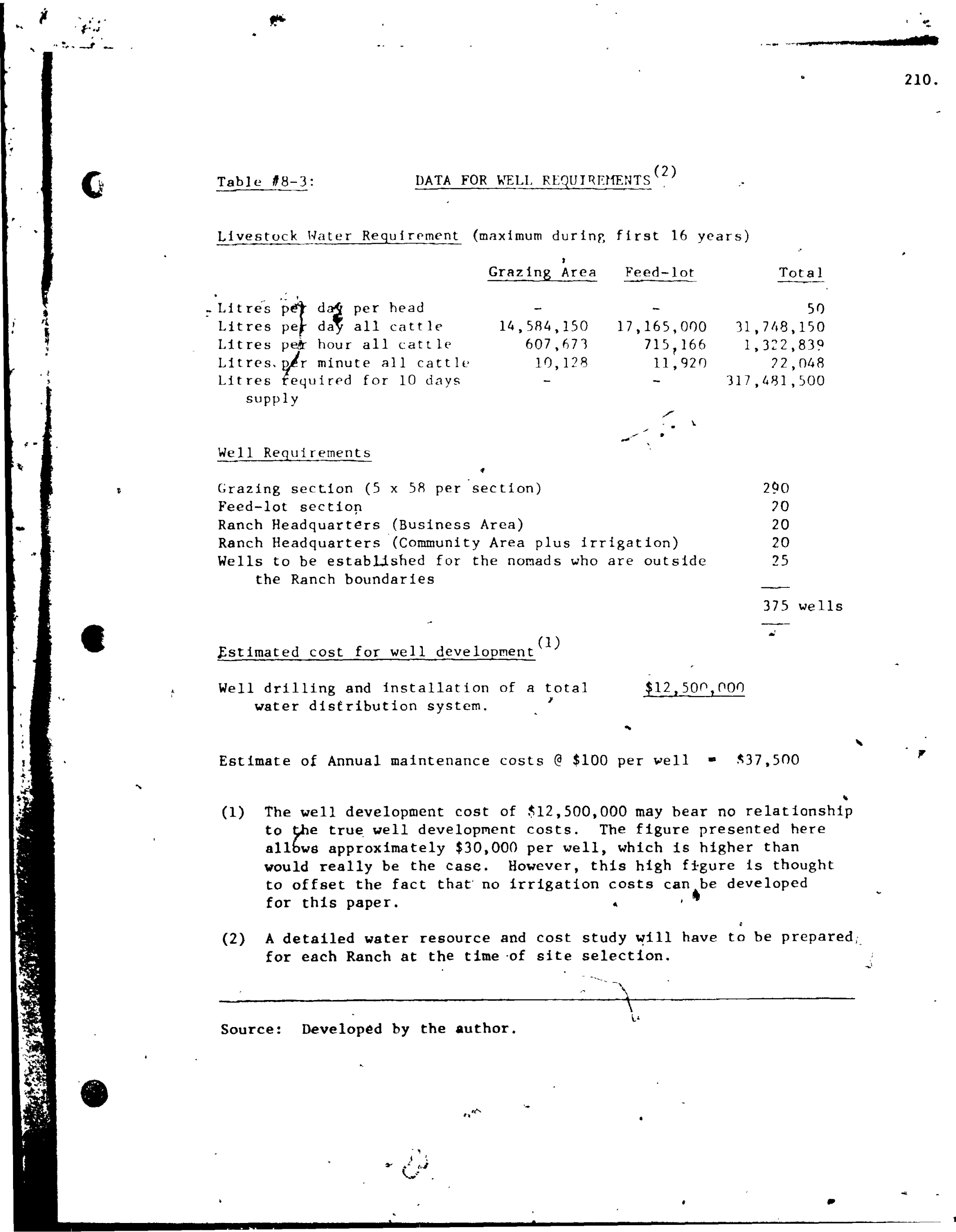


Buggested in the research of Evans and Bryan.

f. Forage Management: Rotation grazing has been outlined as being for a maximum of three months in each vection. However, overstocking and/or close grazing during the dry ${ }^{40}$ son must be monitored to assist the pattern of pasture improvement. An adequate stubble must be maintained during the dry season grazing since it is the stem base which is the essential storage place for carbohydrates. If forage appears to be insufficient to complete the full three month term per section, no premature grazing of the next section must be permitted. Instead, fodder crops will be brought in for supplementary feed as required.

8. Fodder Supplements: One grazing section may be used each 12. year for the production and harvesting of fodder products. Such production will be ensillaged and used as supplementary fodder to prevent overgrazing. Also a system of silos must be developed because ensillaged sorghum, millet and malze will be the feed base for the extensive feed-loy operation,; another important part of the total Ranch complex. After the first feic years of operation with an expanding herd, the Ranch crop cultivation will not be sufficlent to supply the entire sillage requirements of the Ranch. Therefore, the Agricultural Plan must include a scheme for

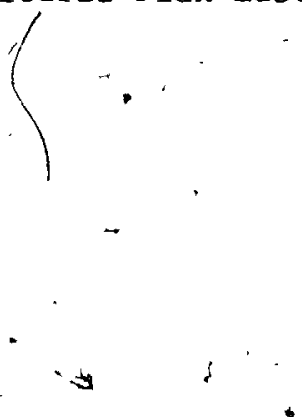


fodder crop cultivation by the sedentary farmers. By this means, a trade linkage will be established between beef cattle and agriculture. The Ranch will be the catalyst Bince it will purchase supplementary fodder crops from the farmer .

THE HERD

a. Composition: The initial herd will be costly since this strategy calls for the purchase of 12,000 head of cattle (the cost estimate is detalled in Table \#8-4).

As far as 18 possible, the inftial herd should consists of Indigenous cattle because research indicates" that exotic breeds have not fared too well in the harsh arid climates 13. of semi-desert regions. 'Ideally, the start-up herd should consist almost exclusively of N'Dama and Fulani stock. However, in Chad, the Kur 1 cattle must be considered since they are the indigenous beasts of that country.

The N'Dama is popular in Senegal, Ma11, Upper Volta and Niger because it is trypanosomiasis resistant and produces excellent meat on relatively poor savannah grazing. The i average weight at maturity is $350 \mathrm{~kg}$. yielding a $54.55 \pi$ dress14. ed weight.

The Fulani 18 a native of Senegal, Maurftanfa, Mal1 and Niger. Again it 18 falrly resistant to tickmborne diseases 
Table $8-4:$

START-UP HEDD

COMPOSITION AND COST ESTIMATE (1)

(U.S. Dollars)

ANIMALS

Cows, purebred ( $3-4$ years) lst year

Bulls, purebred( $3-4$ years) lst year

2nd year

Goats and/or sheep

Chickens

\begin{abstract}
lst year
2nd year

3rd year

4 th year

5 th year

lst year

2nd year

3 rd year

4 th year

5 th year
\end{abstract}

\begin{tabular}{crrr}
$\begin{array}{c}\text { Price Per } \\
\text { Un1t }\end{array}$ & & $\begin{array}{c}\text { Number of } \\
\text { Head }\end{array}$ \\
\cline { 1 - 1 } 150 & & 6,000 \\
150 & & 5,000 \\
& & \\
175 & & 500 \\
175 & & 500 \\
10 & & 1,600 \\
10 & & 200 \\
10 & & 400 \\
10 & & 400 \\
10 & & 1,200 \\
& & \\
1 & & 4,000 \\
1 & & 500 \\
1 & & 1,000 \\
& & 1,000 \\
& & 3,000
\end{tabular}

Tot a 1

Cost

900,000

750,000

97,500

97,500

16,000

2,000

4,000

4,000

12,000

4,000

500

1,000

1,000

3,000

Total Annual Costs Estimated for Animals

$\begin{array}{lr}\text { 1st year } & 1,017,500 \\ \text { 2nd year } & 850,000 \\ \text { 3rd year } & 5,000 \\ \text { 4th year } & 5,000 \\ \text { 5th year } & 15,000\end{array}$

(1) The estimated Price Per Unit only has been taken from, Ranching/Mixed Agricultural Program in Niger, published by Texas Tech. U. 1974. 
with an acceptable dressed weight percentage of $42-517$, 15 . baged on an average slaughter weight of $325 \mathrm{~kg}$.

The Kuri has been suggested for Chad since it is well adapted to the short grasses of the Lake Chad area. This breed dresses out at $50 \pi$ on a slaughter weight of $550 \mathrm{~kg}$.

The Inftial herds would be composed of about 11,000 breeding cows of 3-4 years of age and 1,000 bulls of a simllar age. With this foundation, cross-breeding of the types named could help establish a rellable beef cattle strain for the Sahel region.

¿b. Breeding: Breeding would take place each year between August 1st and September 30th. Apart from this mating perlod, cows and bulls would be grazed separately to avold indiscriminate mating. At a later stage, artificial insemination techniques 17 . will be used extensively to further develop the quality of the herds. The breeding date suggested will vary between the Ranches in each country according to the normal rainfall commencement time. The objective of a clearly defined mating perlod is to ensure the birth of calves in the early part of the wet season. The advantage is two-fold: First, the high nutritional requirements of the cow can more easily be satisfied and she will be in better condition when she calves; the calves thus being assured of a good start. Secondly, the cows will be In better condition during the next service period, thereby improving conception possibilities. 


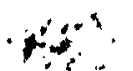

Conception, in this strategy, is accepted as being a very conservation $50 z$ for the first two years with the start up herd. However, the conception rate could increase to 967 by the tenth year through the selection of good breeder cows and artificial insemination.

c. Calving: Presently the age at first calving is of the 18.

order of 42 months, hence the start-up herd consisting of

3-4 year old cows. However, through improved nutrition, it

is anticipated that this time to first calving can be reduced

to 24 months by the sixth year, comenctor with cows born

in the fourth year.

The present calving interval ranges between 14 and 42 . 19.

months, with an average of 18 months. It seems that this

interval is not a reflection of any particular breed, so

much as a reduced conception rate through poor health. Therefore, once again due to improved nutrition, the calving interval can probably be reduced to 12 months by the fifth year of the Ranch operation.

Both the reduced calving interval and the reduced first calving period are embodied in the calculations which were necessary to develop Table $18-2$.

d. Mortality: Calving mortality may be anticipated at $10 z$ 20. post-natal during the first two years of the Ranch, but it should decline to 27 by the eleventh year. 
There is a pre-natal mortality rate which may be as 21.

high as 57 under traditional animal husbandry methods. However, it is felt that with good nutrition and stock management (see section on "Breeding") the pre-natal mortality will be minimized. These mortality percentages are also embodied in Table $8-2$.

e. Slaughter: Under the traditional nomadic system the bulls do not reach mature weight for slaughter unt1l they are $4-5$ years old. In fact, the average slaughter age is 54 months. Cows, of course, are not slaughtered unt1l they are about 10-12 years of age and calf production has finished. However, by this age their meat quality is neg11gible.

With the Ranch operation, all cattle, prior to slaughter, w11l be sent to the feed-lot section (part of the total Ranch complex). The bulls, will, by the tenth year of the Ranch operation, be able to reach maturity in 24 months. They will have been weaned at $81 x$ months and transferred to the Feed-lot section. However, for the final four months before slaughter they would be moved to the intensive Feed-iot area. In the case of the cows, they w111 be taken out of calf proIn the case 23. duction at between $6-8$ years of age. These cows will be slaughtered after 120 days in the intensive Feed-1ot. 


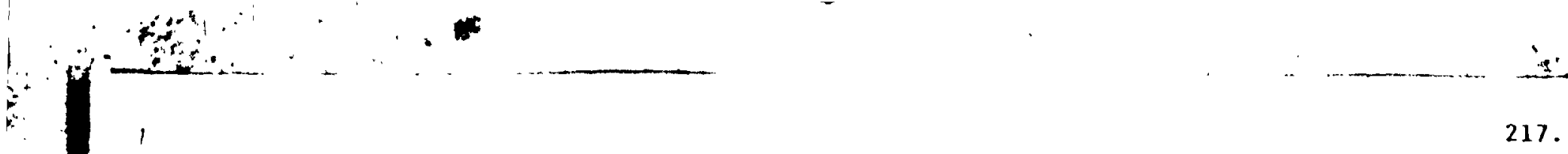

THE FEED-LOT OPERATION

a. Location: The Feed-lot will be located in the central area of the Ranch (see Map 46), occupying an area of approximately 18,750 ha. $(46,312$ acres $)$. It w111 be sub-divided into an Intensive feed area and a pasture feed section; the latter part encompassing about 757 of the total Feed-lot area.

b. Construction: Feed-1ot pens w111 not be of permanent fen-" cing as are the grazing sections. The pens will be of simple construction to permit modifications as stock numbers vary. In addition, shade will be provided over the water and feed troughs in the intensive feed section; such shade being made 24. of thatched matting.

c. Stock Capacity: The required capacity of the Feed-1ot will be 60,000 animals per annum in the intensive feed section with a further 158,000 per annum in the pasture section by the fifteenth year. However, these flgures can be increased to 200,000 per Feed-lot section per annum by the twentieth year, since there w111 be space avallable for feed-lot expansion. Table $8-2$ detalls the numbers of cattle per annum using the Feed-1ot.

The pasture area of the Feed-lot will be entirely devoted to calves after they have been weaned at six months. All calves w111 apend 120 days in the pasture Feed-lot where 
they w11l recelve supplementary feed (ens1llaged fodder crops). After the sug8ested 120 day perlod, the helfers w111 be integrated into the normal rotation grazing system of the main pasture sections with the main herd. However, the young bulls will remain for a further eight months after which they w11 be transferred to the intensive feed-lot for 120 days of fattening before slaughter.

By the twentieth year, the slaughter rate per Ranch could be up to 200,000 head per annum, all of which will require at least 90 days of intensive feeding.

d. Water: For the Feed-lot operation, the capacity to meet a maximum daily need of 400,000 11tres per hour $(88,000 \mathrm{gals})$ must be developed. While this can be accomplished by 20 wells each pumping 20,000 litres per hour $(4,400 \mathrm{gals} / \mathrm{hr})$, it may not be the solution for each feed-lot operation in the Sahel. However, it can be stated that all pumping units in the Feed -Lot areas should be diesel powered because any pump failure could be catastrophic.

In order to develop a total Ranch start-up cost, well construction finances must be included. Thus, Feed-lot well costa are also Included in Table \$8-3.

e. Feed Types: Cattle feed for the Feed-lot really should be sub-divided into two categories for the purposes of cost computation: 
(1) Fodder production

(11) Feed supplements

However, it is not possible to produce Feed-lot feed costs at this stage since there are too many variables and unknown costs. For this reason, such a calculation must be an en1

tirely separate documant taking into consideration the animal feed requirements at different cattle ages, different times of the year, feed prices, feed avallability, transportation and storage.

(1) Fodder Production: Fodder products would be party avallable from the crop cultivation of one grazing sectIon each year, givfing a dry matter yield of 253,000 to 25 .

422,000 metric tonnes. Though this production would serve the Feed-lot needs of the first few years, at a later stage, it would be necessary to purchase fodder from the farmers.

Fodder products such as millet, maize and sorghum - were mentioned earlier as belng easily produced in the Sahel, possibly coupled with Townsille Lucerne. These crops could be ensillaged on the Ranch so that they would be readily avallable for both the Feed-1ot and also, In times of shortage, the main grazing sections.

(11) Feed Supplements: Feed supplements are the key ingredients for the intensive Feed-lot section. It is these ttems which are costly since they are processed 
feed products.

The two most important feed supplements are readily avallable in the Sahel; groundnut ofl meal or cake, and cottonseed meal or cake. Both ltems have high protein value and good cattle acceptability. There are two other supplements which should be used in the Feed-lot operation: First, molasses, which is presently obtainable in Senegal. The second is urea, which can now be produced anywhere with the new simple production processes.

The increased requirement of all four feed supplements in the region of the Sahel could lead to the ratlonalised development of the necessary production faclities in one or other of the Sahel countries.

f. Feed Balance: The cattle in the pasture section of the feed-lot would be fed ensillaged products, which would be supplemerted with salt-1icks and an adequate water supply. However, In the intensive feed-lot section, the suggested feed balance would be of the order of $67 \% \mathrm{~h} 1 \mathrm{gh}$ energy feed supplements combined with only 337 ensillaged roughage. This balance should próduce a satisfactory weight gain and at a lower feef cost/kg gain than would a higher percentage of roughage. 
THE ABATTOIR OPERATION

a. Location: There are few proper abattolrs in the entire region and what few there are fall to meet first class hyglene standards as required by many of the meat importing countries 29.

of the World. Thus, each Ranch would have an ahattoir constructed nearby which would be operated as part of the total Ranch complex. In addition, this close proximity to the Ranch would reduce the tremedous weight loss which usually 30 .

takes place under the traditional marketing process.

b. Operation: The abattolr would process all the marketable stock from the Ranch, a figure that could rise to 200,000 head per year eventually. This annual volume could yield -. approximately 34,000 metric tonnes of meat (an average carcass weight of $340 \mathrm{~kg}$ dressing out at $50 \%$ ).

Since the slaughter-house would be part of the Ranch operation there would be total disease control of the cattle from birth to market. In addition, the veterinary staff of the Ranch would be responsible for the sanitary operation of the abattoir and its inftal construction. Subsequently, as the disease Free Zone is expanded beyond the Ranch confines, the other nomadic cattle could be fattened on the Feed-lot. Hence, the abattoll would be handling some additional slaughter and marketing.

c. Markets: Carcasses could be shipped by refrigerated truck, 
or by alr, to the markets of West and Central Africa, and even Europe. The markets of Europe would be open to the Sahe] beef because the health requirements would have been met by controlled stock rafsing and the close veterinary supervision.

The FAO estimated that there would be a net meat short-

age In West Africa of approximately 318,000 metric tonnes by 1985. However, due to the Increasing urbanisation and the expected meat consumption increase in Afrlia, the net shortage could go even higher.

Besides a meat shortage in Africa, there will also be a considerable meat shortage in Europe. In 1970, the European 32. shortage was estimated at 575,000 , metric tonnes, though this could be well in excess of 1 million metric tonnes by 1980 and possibly 2 million metric tonnes by 1990.

Under the strategy of this paper, a single Ranch may be expected to produce 34,000 metric tonnes by 1990 , with a total of over 200,000 metric tonnes being produced by the ortginal six Ranches proposed. While this volume would account for only a small percentage of the European shortage, it could provide a substantial share of the anticipated West African meat shortage, besides being a better quality than had been exported from the Sahel in previous years. Exports would not be able to go enctrely to Europe, despite the future needs of foreign exchange. Thus, exports would have to be 
divided between both the furopean markets (which may be able to pay higher prices) and the markets of the other West African countries.

However, not all the Sahel beef would go for export. It must also be remembered that there is a domestic market need for meat which must be met. Part of this domestic requirement could, of course, be derived from an expansion of the Ranch programe to other areas, since the live cattle could be made avallable to reduce the inftial start-up costs of subsequent operations. In addition, it was suggested that nomadic cattle could be fattened in the Feed-lot section, these being then sold In the domestic markets thereby satisfying the traditional requirement that meat be consumed only from the freshly killed stock.

d. Benefits: Since the slaughtering and marketing operations will be totally controlled by the Ranch, another major benef 1 t begides the sale of processed meat will be realised by the Ranch 1 Management. This benef1t w11 accrue through the local use and distribution of the cattle by-products such as hides, horns, bone meal, animal tallow and fertiliser. Thus, another Important economic linkage can be developed from a successful beef industry in an area. From the Ranch operation there would be no export of $!$ 


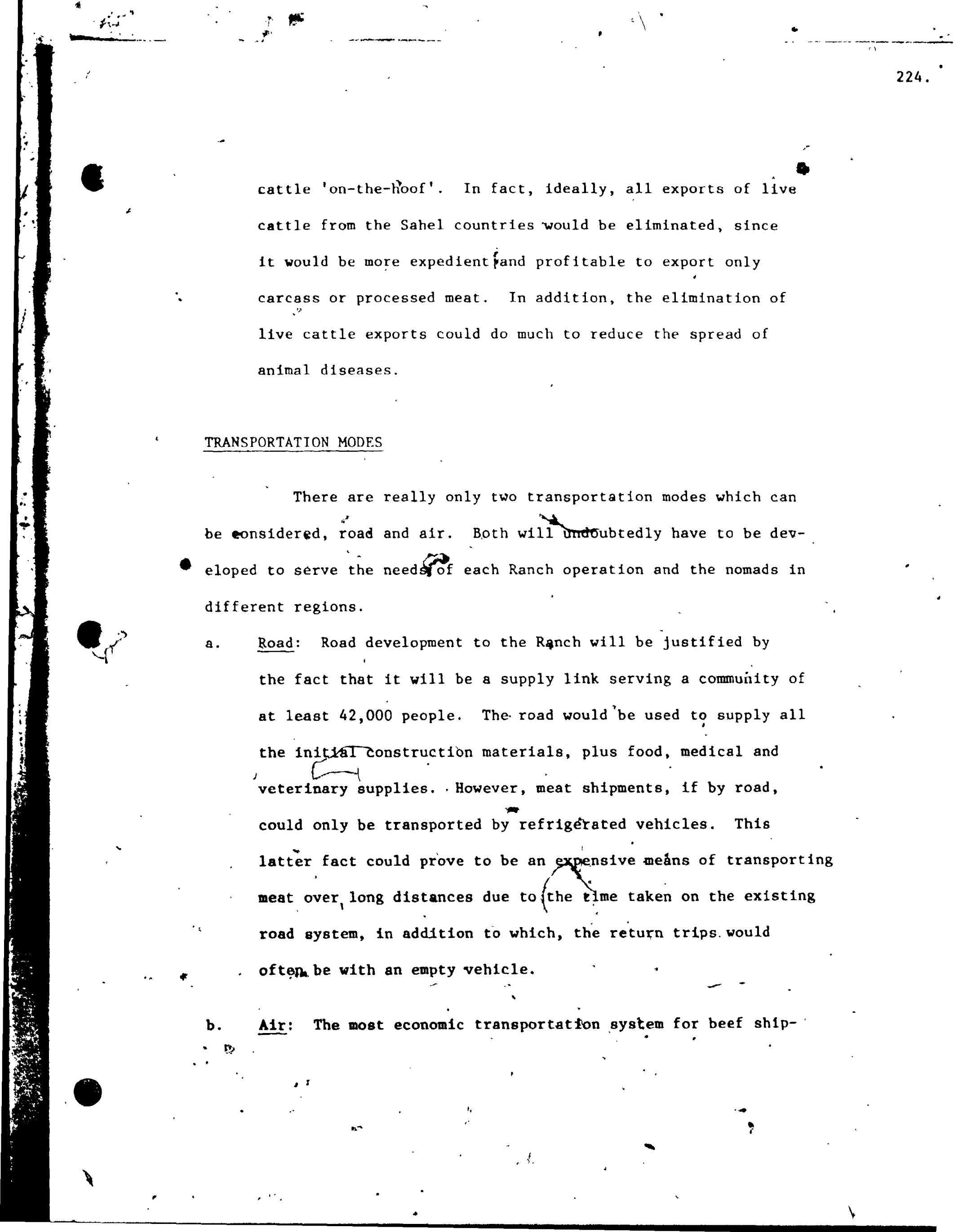




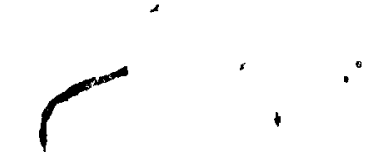

33.

ments could well be the 'expensive' alr freight. Although air costs are higher than by road, rail, or even ocean shipping, the time-savings' on 'capital in the plpeline' thay more than offset the difference in costs. Alr transportation has already been proved more economical for the fruit and vegetables flying from East Africa to the markets of Europe.

Also, air frelght is already being used for certain meat ship34.

ments from Chad over relatively short distances. The pros-

pects for als transport could be further improved due to the advent of the glant aircraft which have greater capacities and a correspondingly lower cost per ton/mile.

It should be noted that in addition, air transportation reduces the refrigeration problems inherent to land and sea shipments. The International Civil Aviation Organisation (ICAO) will presently be undertaking a study of the air transportation mode to assess its practicability.

c. Other Modes of Transportation: River transportation, while 1t has some benefits for other sectors of the Sahel economies, would not prove too useful for meat shipments. Besides the special refrigeration needed on vesiels for perishable goods storage, river navigation in the Sahel has not yet been developed to provide any degree of reliability. Ra11 trapsportation is another alternative, but the 
development of this mode of transport is still in its infancy. In addition to which, the Ranches would have to use trucks in order to take the meat to the rallhead, a factor which would not help reduce the Ranch costs.

\section{DISEASE CONTROL}

Each Ranch will have a Veterinary unit as part of its operating staff. The primary function of this unit will, of course, be disgase control and disease prevention in the cattle herd. This can be accomplished by a programme of vaccination of calves during the weaning period, thereby providing a considerable degree of protection against the major diseases. Controlled animal movement, by virtue of the fencing, will also do much to ald disease control.

The Veterinary unit w11l also be responsible for a continuous programme of water testing besides the checking of wild antmal diseases and movements. In addition, the unit will be directly responsible for sanitation and the dally operation of the abattoir.

\section{BAPLOYMENT OF NOMADS}

36.

Though the IBRD Report called for a flve year programme alned at serving 200,000 to 250,000 fanllies of the nomadic population. 
the strategy presented herein clearly falls to reach that object1ve. Each Ranch will provide a livelihood for only about 7,000 familles by the twentleth year. Th1s figure translates into a total of 42,000 families in the Sahel; only $20 z$ of the target set out in the IBRD Report. In addition, the 42,000 families involved will take place only after a twenty year period, considerably longer than the IBRD goal of five years.

Table 8-5, detalls the estrmates of staff and wages which will be needed to operate the Ranch on an annual basis. However, the listing can only consider the direct employment generated by each Ranch. But there must be considerable employment generated Indirectly from the establishment of beef cattle Ranches.

Initlally, the nomadic herdsmen and their families will only be able to provide the manual labour needed on the Ranch, a1though they w11l assume more responsibility under the guldance of expert management personnel. However, through soct levelopment programmes, including education, it is expected that after a few. years of work and job-training the nomads would be able to assume many of the supervisory responsibilities on the Ranch.

Clearly, the employment of nomads may be difficult from soctological point of view because of the need for education and also because of the various tribal traditions which exists. Thus, 
Table 8-5:

\begin{tabular}{c} 
ESTIMATED ANNUAL PAYROLL \\
AND \\
STAFF RLQUIREIENTS \\
\hline
\end{tabular}

(U.S. Dollars)

YEARS

PERSONNEL

$1-5$

6-14

$\underline{15-20}$

Ranch Manager

Deputy Ranch Manager

Superintendants - Feed-lot

Abattoir

Marketing

Veterinary

Water

Grazing

$\begin{aligned} & \text { Managers - } \text { Accountant/Business } \\ & \text { Community } \\ & \text { Transport/Warehouse }\end{aligned}$

Supervisory Personnel $(9 \times 11,000)$

Counterpart Trainees $(11 \times 10,000)$

Superintendant \& Management Assistant $(11 \times 10,000)$

Secretaries $(2 \times 15,000)$

Secretaries $(3 \times 7,000)$

Clerks $\quad(4 \times 3,000)$

Nechanics $(9 \times 5,000)$

Pilot

Labourers ( $400 \times 200$ 1st year)

$(900 \times 2005$ th year)

Labourers $(1,100 \times 4006 \mathrm{th}$ year)

$(3,240 \times 40014$ th year)

Labourers $(4,500 \times 60015$ th year)

$(7,000 \times 60020$ th year $)$

$\begin{array}{lll}45,000(a) & 45,000(a) & 25,000(a) \\ 40,000(a) & 40,000(a) & 20,000(\mathrm{~b}) \\ 35,000(a) & 15,000(\mathrm{c}) & 15,000(\mathrm{c}) \\ 35,000(\mathrm{a}) & 15,000(\mathrm{c}) & 15,000(\mathrm{c}) \\ 35,000(\mathrm{a}) & 15,000(\mathrm{c}) & 15,000(\mathrm{c}) \\ 35,000(\mathrm{a}) & 15,000(\mathrm{c}) & 15,000(\mathrm{c}) \\ 35,000(\mathrm{a}) & 15,000(\mathrm{c}) & 15,000(\mathrm{c}) \\ 35,000(\mathrm{a}) & 15,000(\mathrm{c}) & 15,000(\mathrm{c})\end{array}$

$35,000(a) \quad 15,000(c) \quad 15,000(c)$

$35,000(a) \quad 15,000(c) \quad 15,000(c)$

$35,000(a) \quad 15,000(c) \quad 15,000(c)$

$90,000(c)$

$110,000(\mathrm{c})$

$90,000(c)$

$90,000(c)$$$
-
$$

$110,000(c)$

$110,000(c)$

30,000 (a)

$12, \bar{n} 00(d)$

45, 000 (d)

$15,000(\mathrm{c})$

$80,000(e)$

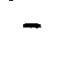

$-$

-

-

-

$$
21,000(d)
$$

$12,000(d)$

$45,000(d)$

$15,000(c)$

$-$

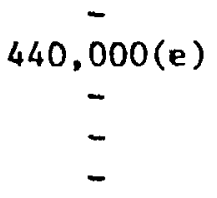

$21,000(d)$

$12,000(d)$

$45,000(d)$

$15,000(c)$
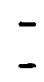

$2,700,000(e)$

$\begin{array}{lcc}\begin{array}{c}782,000 \\ \text { to }\end{array} & \begin{array}{c}933,000 \\ \text { to }\end{array} & 3,173 \\ 882,000 & 1,789,000 & 4,673 \\ \text { tues } & & \\ \text { acation and proven ability } \\ \text { achyool plus technical college } \\ \text { education as soon as possible }\end{array}$

(a) Personnel from aid donor countries

(b) Indigenous people with high education and proven ability

(c) Indigenous people with secondary school plus technical college

(d) Indigenous people with secondary school

(e) Indigenous people with primary education as soon as possible

Source: Developed by the author. 
chapter $X$, will consider some the social implications of the Ranch beef strategy operating method which w1ll be detalled in chapter IX.

\section{LONG TERM POSSIBILITIES}

The market potential after about twenty years, for all six Ranches, is only about 1,200,000 head per annum (approximately 107 of the herds existing in the Sahel in 1972). However, these Ranches will provide; firstly, a solid economic base for a nomad operated beef Industry. Secondly, these six Ranches will be workIng economic models and not just show-places. Hopefully, other similar Ranches may then be established in other areas of the Sahel.

a. Additional Ranches: Each Sahel country has more than enough permanent pastureland so that two or three similar Ranches can easily be established in other sections of the region. As was mentioned earlier, the start-up costs for other Ranch operations should not be as high as those incurred by the inftial Ranches. The second serles would be stocked from the Initial models using proven developed cattle. Thus, the newer Ranch establishments could possibly become economically viable within a two year period because of the reduced period to first calving, the earlier slaughter-weight maturity, and the reduced calving interval. 
b. Ranch Expansion: The Initlal Ranch expansion has been explatned under "The Herd", since the orfginal fence boundarles are enough to allow considerable herd expansion. But, 1t is expected that other nomadic herdsmen will, after observation of the Ranch operation, be interested in the further development of disease free healthy stock. In addition, the easier and more profitable market system should provide an economic incentive to a people who are progressively feeling the pressures of a monetary economy.

c. Feed-Lot Addition: Additional feed-lot operations could eventually be established in the more southern farm areas of the Sahel. These would be separate business enterprises set-up divorced from any Ranch. Such feed-lots may even be developed on a co-operative basis among the sedentary farmers. They would trade their grain products for cattle with some of the nomadic herdamen because there would be many nomads sti1l leading the traditional lifestyle.

The market for these additional feed-lot operations would probably be more orlented fowards the domestic markets, due to the lack of disease control in such businesses: Nevertheless, they would still be able to benefit from some exports, albelt only short distance exports to neighbouring countries. 
Chapter VIII commenced with a listing of the underlying premlses upon which the beef development strategy of this paper was bullt. After which, the long-term alms were consldered, though it was clarifled that these final objectives were 'broad in nature' and thus subject to modification, at least with regard to the time parameter .

of course, the final objectives were suggested as being inadequate by themselves for the development of any strategy, since all projects must have some form of interim progress measurement. Hence, intermediate aims were shown to be very important and accordingly were specified. After which, the Beef Cattle Development Strategy was set forth.

The Strategy may appear, at first glance, to be very categoric and therefore rigid. But, this is really not the case, since a degree of flexiblifty has been allowed concerning the time parameters of both the intermediate and long-term aims. This 'time' factor is the only flexibility that the writer chooses to consider at this stage. The Plan may be otherwise considered as rigid, in that, it is the viewpoint of the author based on the premises original specified.

Having considered the Strategy, it now behooves the author to suggest the method of implementation. Th1s is because, though there could be many ideas as to how a given strategy can be put into practice, when a individual develops a strategy, that person will have very specific thoughts on how his theory can be turned into a practical opplication if his final resulte are to be obteined. As a result of this, chapter suggest, what is for the author, a very logical method of etrategy implementation. 


\section{FOOTNOTES}

1. Indicat1ve World Plan for Agricultural Development to 1975 and 1985, Vol.I. Published by the FAO, Rom, 1968. p. 253.

2. Ranching/Mixed Agriculture Program in Niger, A study by Texas Tech University, Texas, June, 1974. p.10.

3. A conservative stocking rate when compared to the study results of P. Granier as reported in Ranching/Mixed Agriculture Program in Niger, Ibid, p.55. and even the work of J.Phillips, The Development of Agriculture and Forestry in the Tropics - Patterns, Problems and Promises, London, 1961. p.172. This lat ter work being cited in chapter VII.

4. J.Griffths Davies and A.G.Eyles, "Communication of Results", in W. Davies and C.L.Skidmore edftion of Troplcal Pastures, London, 1966. P. 153

5. J-P Baudelaire, "Water for Livestock in Semi-Arid Zones", in World Animal Review, No.3, 1972. Published by the FAO, Rome. Also cited in chapter VII.

6. H.P.Miller, "The effect of pre-treatment of native pasture and sowing rate on establishment of Townsville Lucerne on Tippera clay loam at Katherine, N.T." In Australlan Journal of Experimental Agriculture and Animal Husbandry, Vol.\#7, 1967, p.515. Also cited in chapter VII.

7. Indicative World Plan for Agricultural Development to 1975 and 1985, Vol.I. p.160ff. and also chapter VII.

8. M.J.T.Norman, "The effect of burning and seasonal rainfall on native pastures at Katherine, N.T." in the Aus. J. of Exp. Ag. and A.H., Vol.19,1969,P.295. and chapter VII.

9. Ranching/Mixed Agriculture, op.c1t. P.M-2. Indicates $\$ 500$ per ton.

10. B.G.lever, "Agricultural Extension in Botswana", In Development Studies, 17,1970 . p.57.

11. T.R.Evans and W.H.Bryan, "Livestock change and beef proariction" in Aus. J. of Exp. Agr1C. and A.H. Vol. 13, 1973.P. 530 
12. Due to the rotation system of grazing suggested, only four sections will be grazed each year. Therefore, the fifth section will be avallable for the production of fodder crop for ensillage. Method of cultivation and the type of crops was suggested in chapter VII.

13. Studies cited in chapter VII, Indicated that though exotic breeds have been successfully introduced into other parts of Africa, these same breeds, when introduced to West Africa, did not fair so well in the harsher climate. Hence, research presently being undertaken in the Sahel is primarily attempting to improve the Indigenous zebu cattle.

14. Types and Breeds of African Cattle, published by the FAO, Rome, 1958. p.118ff. This information was mentioned in chapter VII, however, the detall has been listed again due to the Importance to a fully understanding of the strategy and the subsequent profitability calculations.

15. Ib1d., p.86ff.

16. Ibid., p.139ff.

17. Artificlal insemination will be introduced gradually over a period of several years since this will be a new technique to the nomads. Introduction of this method will only move at the speed with which the nomadic herdsmen are prepared to accept the method.

18. Types and breeds of African Cattle, op.cit.

19. K.L.Sjorberg and S.Persson, Cattle Production in Africa, Rural Development Study No.2. College of Agriculture, Sweden, March, 1974.

20. Ibid., p.41 ff.

21. Ibid., p. 41 .

22. Ibid., p.57 ff.

23. Ib1d., p.46.

24. Ranching/Mixed Agriculture Program in Niger, op.cit. p.46.

25. H.P. Miller, op.c1t. p.517. 


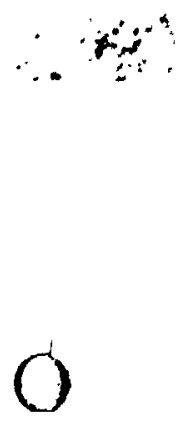

CHAPTER NINE

RANCH OPERATING METHOD AND

FINANCING

Introduction

Ranch Operation

Ranch Ownership

Financial Matters

(a) Capital

(b) Annual Costs

(c) Annual Revenues

(d) Profit and Loss

(e) Capital Investment Funding

(f) Annual Operating Funds

Summary 
CHAPTER NINE

RANCH OPEPATING METHOD AND

FINANCING

INTRODUCTION

Experfences of history, and a number of development projects, have shown that the process of modernisation is slow and that old ideas die hard. Thus, the Ranch strategy of Chapter VIII cannot suddenly be introduced into the Sahel with the view of changing the nomadic life-style in the first five years. However, this change can be brought about by an approach of gradual nomadic involvement over a twenty-year perlod. In this way, the second generation of Ranch workers could posstbly form a solld foundation for a modernised Ranch economy, thereby contributing in a substantial manner to the future development of the entire Sahel region.

Th1s chapter will, therefore, spell out the method of Implementing the Ranch strategy, with stress being 1 aid on the gradual nomadic involvement. In addition, some estimates of cost/benefit w11 be considered so that the required development financial needs may be considered.

\section{RANCH OPERATION}

The Ranch would be built and stocked with cattle during the 
course of the first two years. The first year would see the involvement of 400 nomadic families, with a further fifty families being brought on to the Ranch in the second year (see Table 19-1: Nomadic Families Involved Annually in the Panch Operation). It should be noted that additional famflies will be integrated into the Ranch complex during the first twenty years up to a total of 7,000 famlifes (a total of approximately 42,000 people forming, the Ranch community). Map \#6, Indicates where these people will live on the Ranch, the Community Area being clearly shown. The Map also shows that there is no outer boundary fence for the Community Area, thus, allowing for an expansion of both the number of familles and in the area to be irrigated for family use.

The nomadic families which commence during the first few years of Ranch operation will be families who have lost all their animals. Each family would then, upon arrival, recelve the following 81ft:

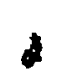

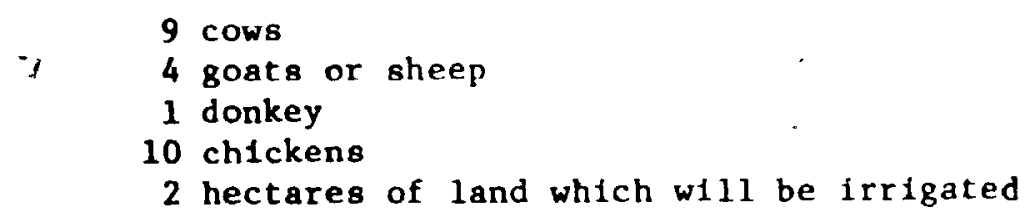

The goats, sheep and chickens would be raintained in the Community Area, However, the cows would be integrated with the Ranch herd and grazed in the enclased Grazing Sections (also shown on Map 6). By this cattle integration, the cows owned by the nomads would recelve the same feed, veterinary service and general care as the Ranch, Herd. 


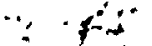


Wh1le the nomadic famllies w111 recelve stock and land, they will be expected to do labour work around the Ranch; in addition to tending the Ranch herd. Such labour work will be a permanent part of the Ranch operation and include such items as general construction, fence, well and pump installation, plus normal maintenance. These fobs will necessitate working under a Supervisor and require the use of motor transportation. For these additional labours, the workers would recelve a salary of $\$ 200$ per annum during the first five years. This annual pay would increase to $\$ 400$ per family per annum, for years, six to fourteen inclusive. After which there would be a further increase to $\$ 600$ in the fifteenth and subsequent years, combined with some form of co-operative profit sharing.

The families joining the Ranch could be from different tribes, some of which are traditionally hostile towards each other. For this reason, whlle they may be prepared to work side-by-side, they will probably choose to live in separate sections of the Community Area. Hence, the Community Manager w11l be well advised to work with, and through, the Head Man of each tribal groupting. It Is hoped that by working together and eventually operating the Ranch as a team, the tribes will learn to co-exist in a peaceful manner. However, real tribal integration may not come about before the, second, or even the third generation of Ranch families.

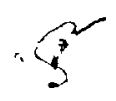




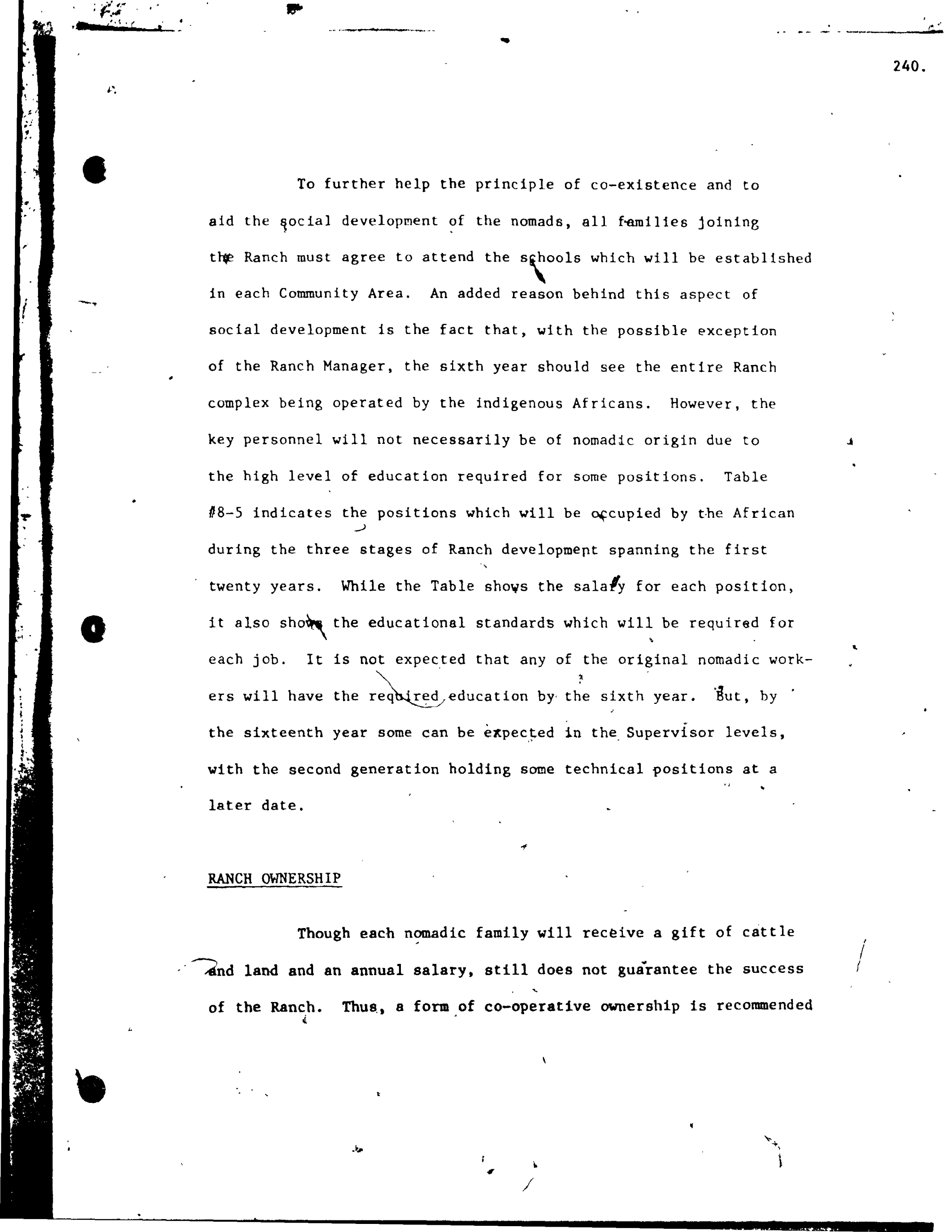




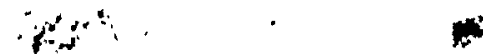


required for success are time and patience. After all, though tt may take twenty years to establish a complete Ranch Co-operative, such a move will do much to integrate the nomads into the mainstream of the national and regional economic life.

\section{FINANCIAL MATTERS}

a. Capital: The Capital Investment required per Ranch would be slightly in excess of $\$ 16$ milion during the first five years (see Table \#9-2 and \#9-3). However, all future Ranch Investment needs will be satisfied hy the Ranch profits.

b. Annual Costs: An estimate of the Annual operating costs is given in Table \#9-4. This Table indicates the anticipated major details, but the figures shown are only a guide. Accurate Annual Cost projections can only be given after the Ranch site selection has been made. It should also be mentioned that no two Ranch locations fwill have the same costs structure since each country w111 have different varlables.

In the computation to develop the Annual Costs on Table 19-4, there has been a tendency towards over-stating the expenses. "This has been done so that the final profit calculations will not appear to be too optimistic.

c. Annual Revenues: The Annual Revenues for the Ranch will only be derived from the slaughtered animals. Obviously, after the 


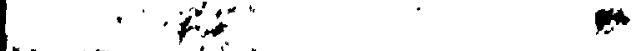

Table \#9-2:

ESTIMATED REAL PROPERTY
CAPITAL REQUIREIENTS
(U.S. DOllars)

TOTAL

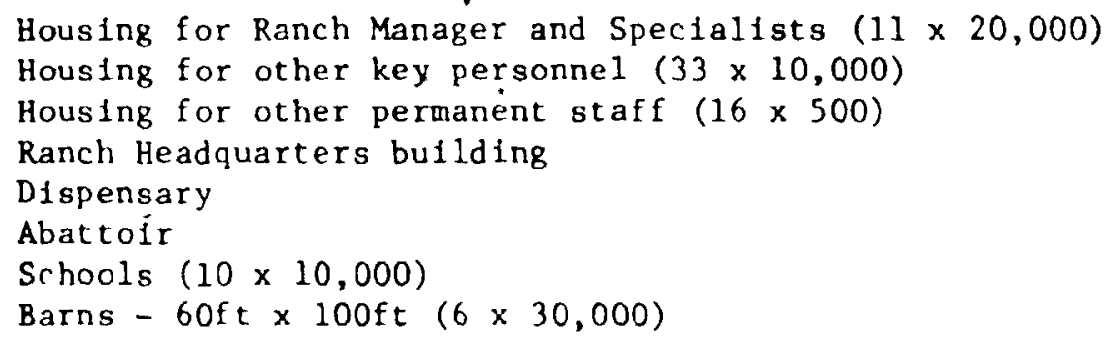

Annual Depreciation of $3 \%=\$ 11,907$ for $3 \mathrm{rd}$ year Annual maintenance cost $2 \%=\$ 7,938$

Machinery and Equipment (includes trucks and an aircraft)

Annual Depreciation of $10 \%=\$ 25,000$ 2nd year

$=\$ 50,0003 \mathrm{rd}$ year

$=\$ 52,5004 \mathrm{th}$ year

$=\$ 55,0005 \mathrm{th}$ year

Annual maintenance cost $1 \%=\$ 5,500$

(1) Whyle some of the above data was taken from the Texas Tech. University study on Niger, 1974, it provides only a guide. Each country of the Sahel will have different cost factors and therefore the true capital requirements 'will have to be calculated for each individual Ranch once the site selection has been made.

Source: Developed by the author. 
0

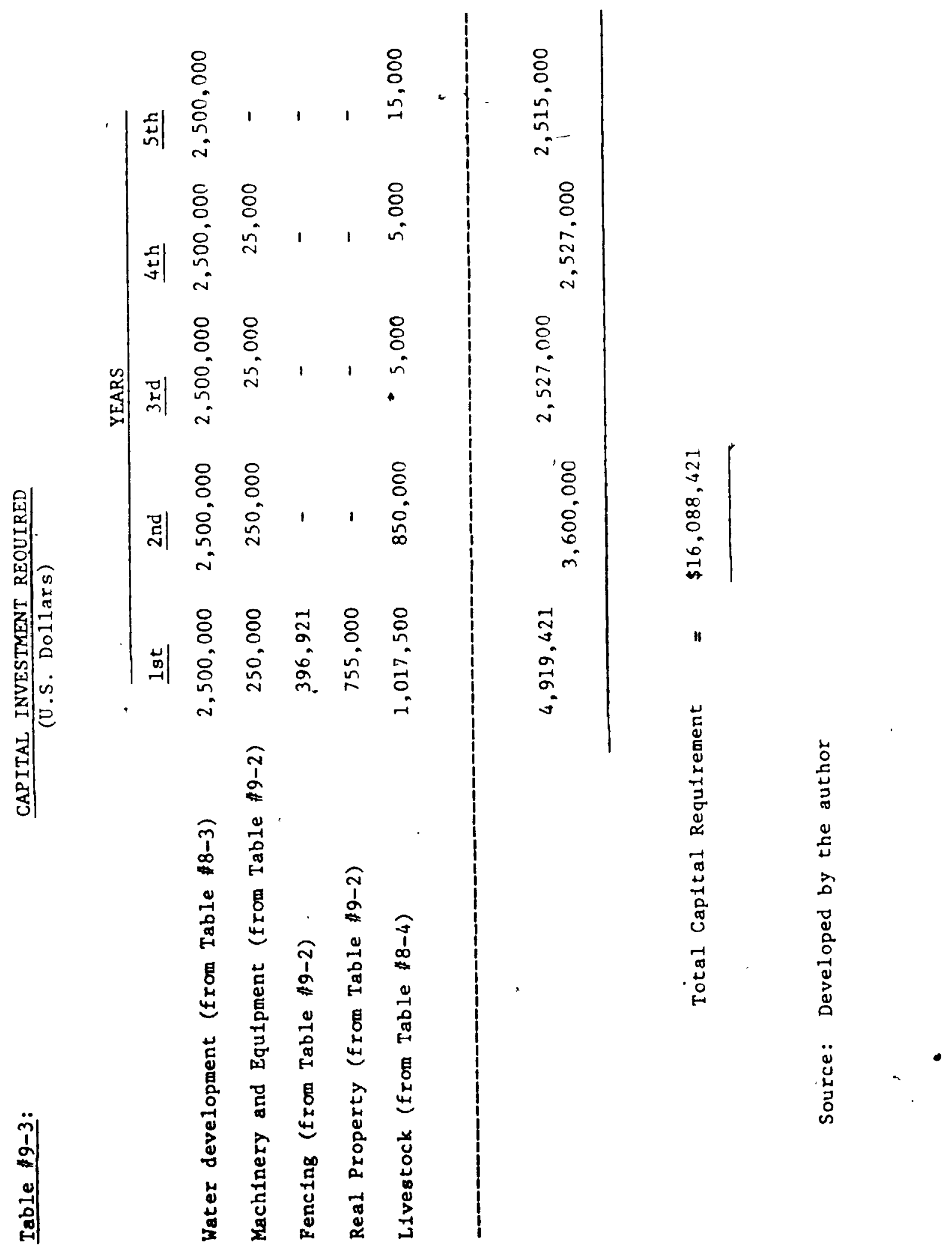


Table 19-4: ESTIMATED ANNUAL OPERATING COSTS (U.S. Dollars)

()

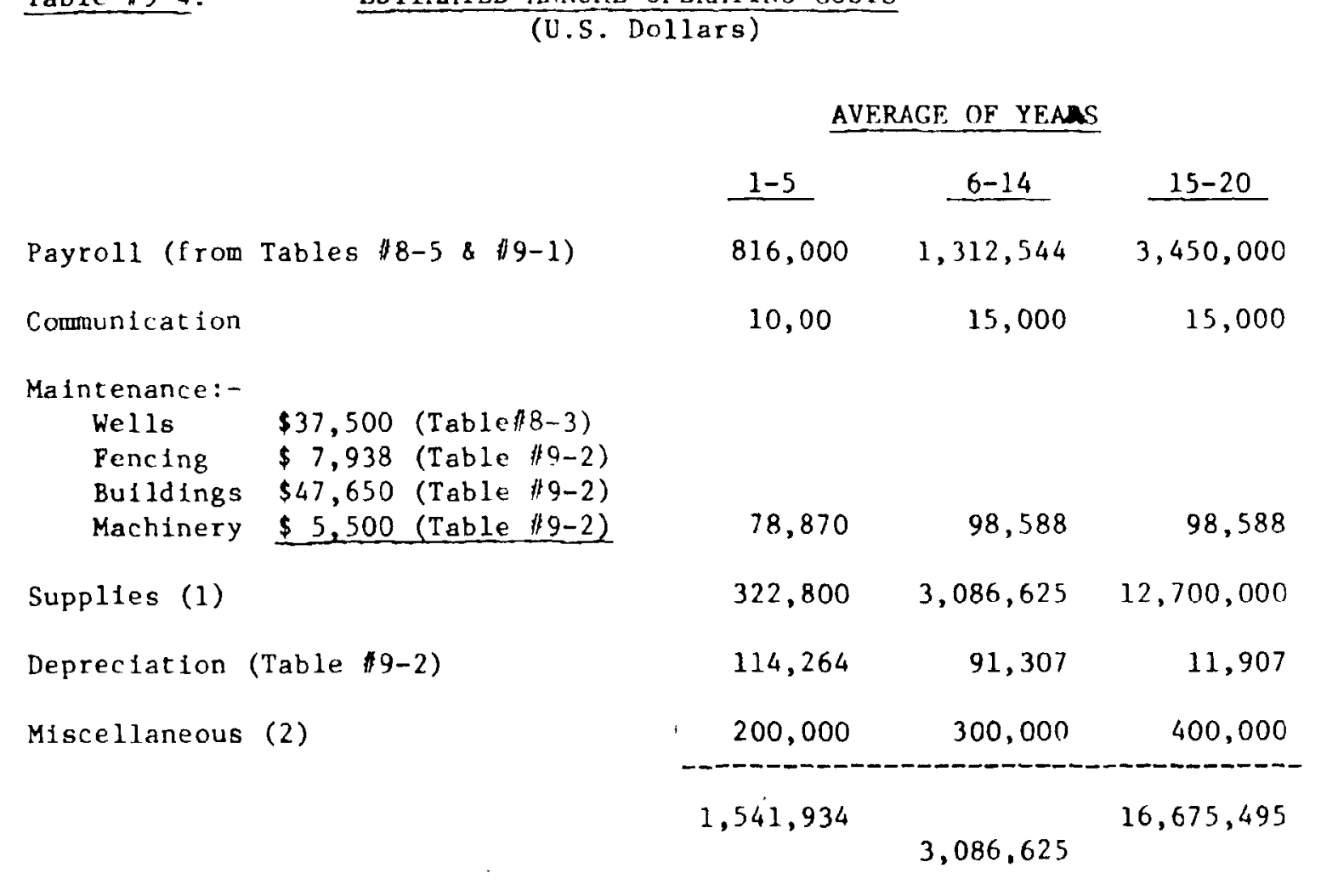

(1) Supplies consisting of:

(2) Miscellaneous 1tems:
Fuels and lubricants

Fert111sers

Seed

Supplementary feed

Machinery parts

Medical and Veterinary supplies

School supplies

Miscellaneous iters

Additional salarles not in budget

Administrative support (consultants etc.)

Trave 1 (National and International)

Insurance

Fringe Benefits

Special courses for personnel

Source: Developed by the author 


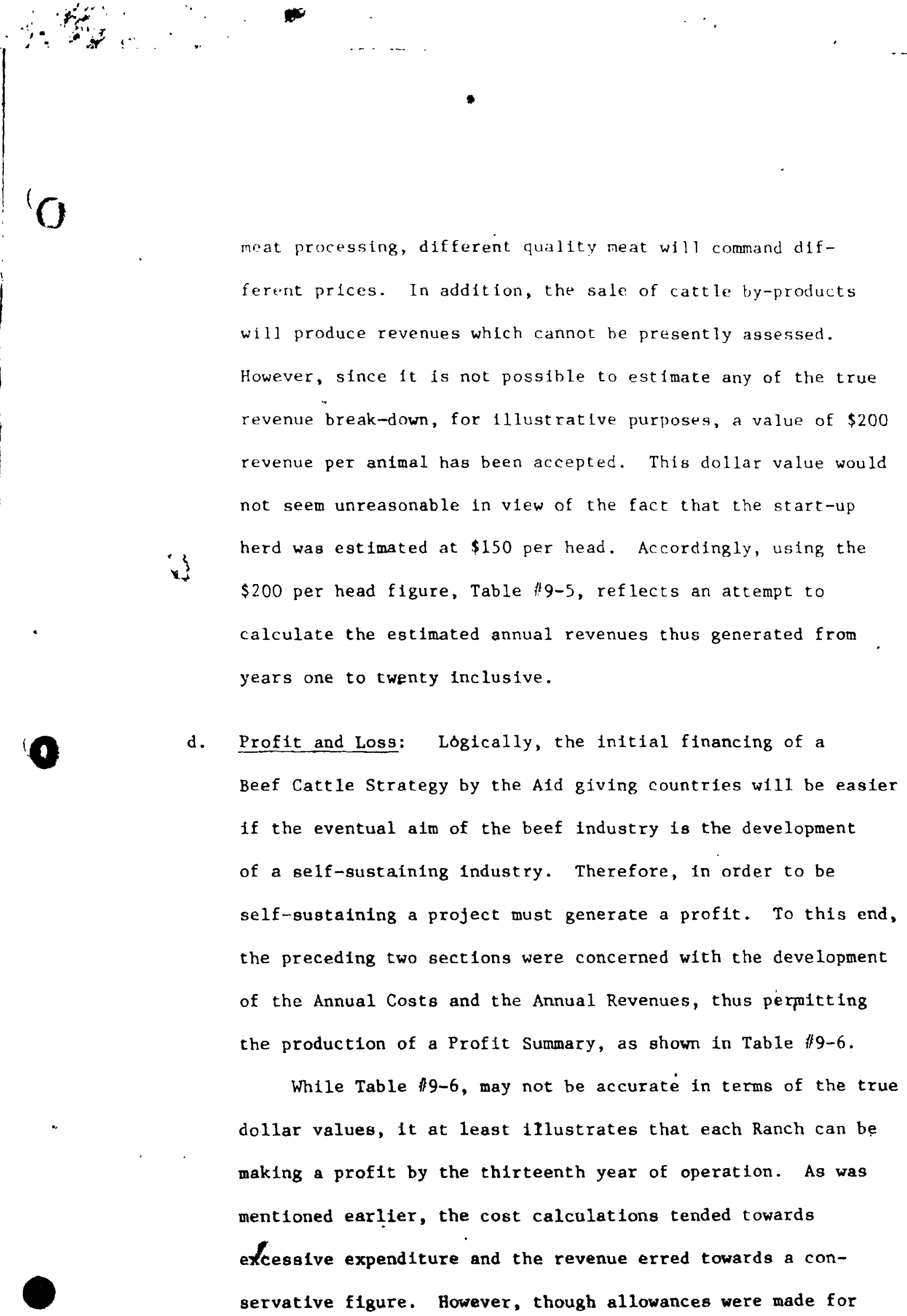


(1). Table \$9-5:
ESTIMATED ANNUAL REVENUE

FROM

LIVESTOCK SALES

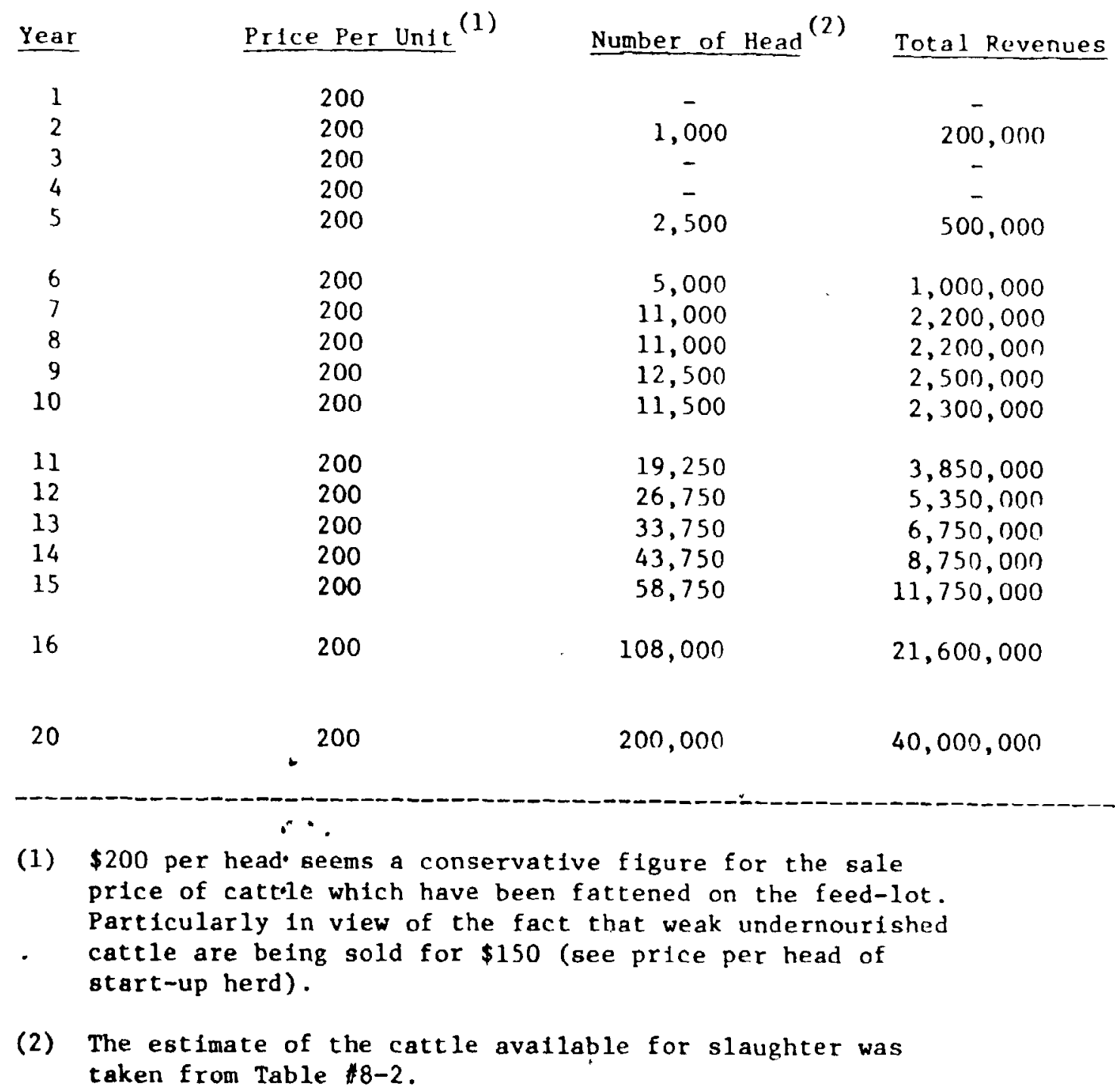

Source: Developed by the author. 


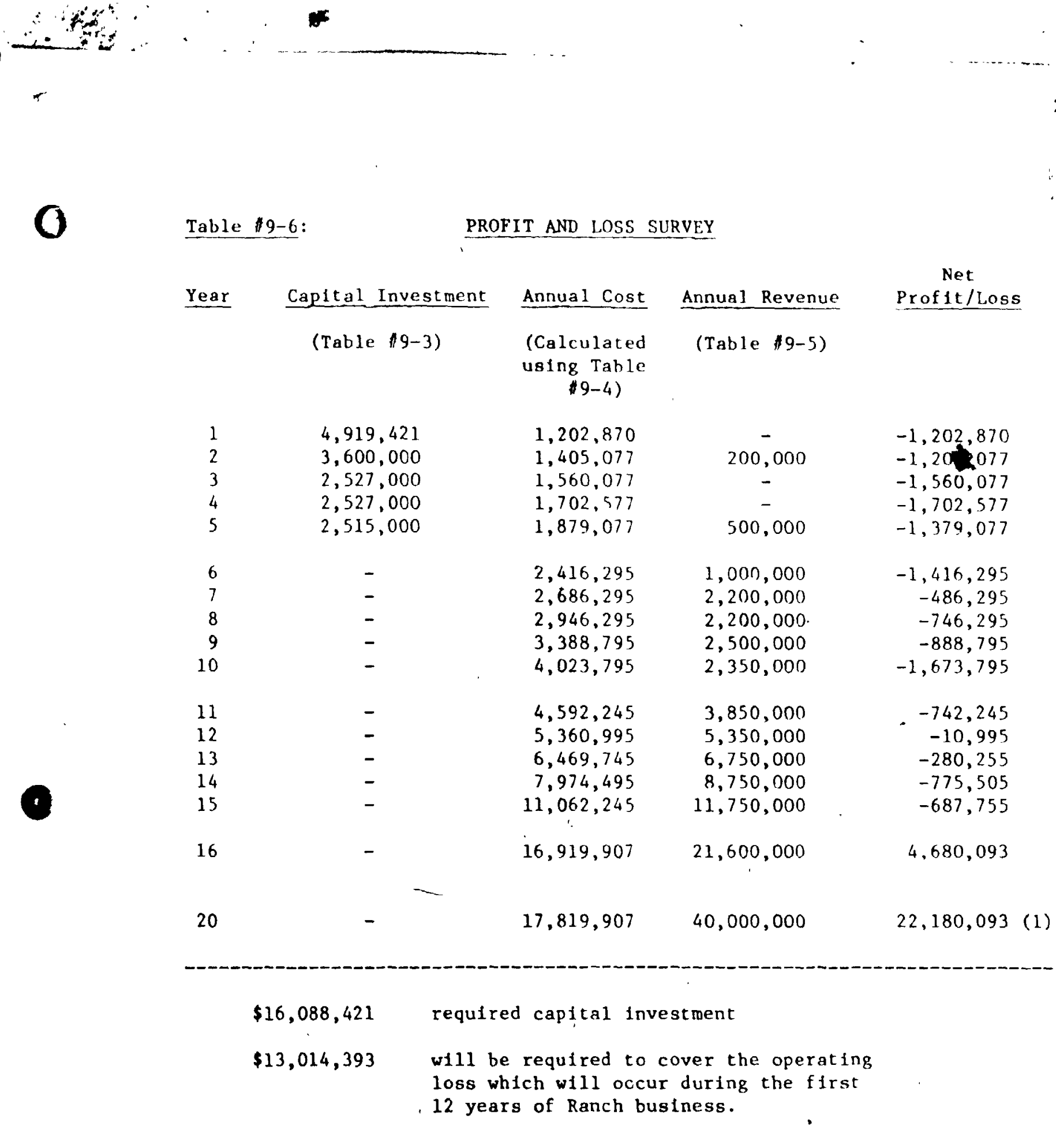

(1) While the profit for the' 20 th year appears to be $\$ 22$ million this will not truly be the case. By that point in time, much of the capital will be required for expansior. and the renewal of worn machinery. However, a $\$ 5$ to $\$ 10$ million profit would be expected annually before taxes and investments.

Source: Developed by the author. 
changes in the depreciation, wages, and supply changes, neither the Annual Costs nor the Annual Revenues made any attempt to consider an inflation factor.

It should be noted that Table $\$ 9-6$, lists the total Captal required separately from the amount of funding that will be needed to keep the Ranch solvent during the early years. This is because it is felt that the two different amounts of money can be handled in two different ways.

e. Cap1tal Investment Fund1ng: The Initial Capital Investment cculd be provided as an outright cash grant by one of the ald donor countries. Should a nation prefer to send aid in the form of personnel or equipment, then such gifts must conform exactly to the needs of the Plan for Beef Development. Any deviation from the strategy for beef would be the 'thin edge of the wedge' and therefore not acceptable. However, this aspect of negotiating the ald requirement will not be a factor borne by either the Ranch personnel or the individual National Governments. Obtaining the necessary Capital funding will be the responsiblitity of a new organisation whlch is proposed in Chapter XI of this paper.

f. Annual Operating Funds: A total of $\$ 13,014,393$ is required to finance the Annual Ranch operation during the initial 12 years. However, this amount could be donated by one of the 
ald agencies in the form of an 'intedst. free loan' repayable after a twenty-year period. Again, the negotiations for this operating capltal would be handled by the new organisation of Chapter XI, since the bargaining would be on behalf of all six Ranches for the entire Regional Beef Industry .

The funds required are not necessarlly the true amounts which will be needed by each Ranch. The Tables showing Costs, Revenues and also the Prof 1 t and Loss Summary have been developed for illustrative purposes. However, an attempt has been made to obtain as much accuracy as possible while trying to fllustrate the direction such Ranch operations will take towards the aim of a 'self-sustaining beef industry' in the Sahe1.

SUMMARY

Th1s chapter provided a most important description of the Ranch Operating Method that should be employed to implement this P1an. While it is well understood that sometimes more than one approach may be used to implement a particular scheme, the system suggested in this chapter was developed to ensure a reasonable choice at meeting all the long-term and intermediate alms suggested in chapter VIII. 



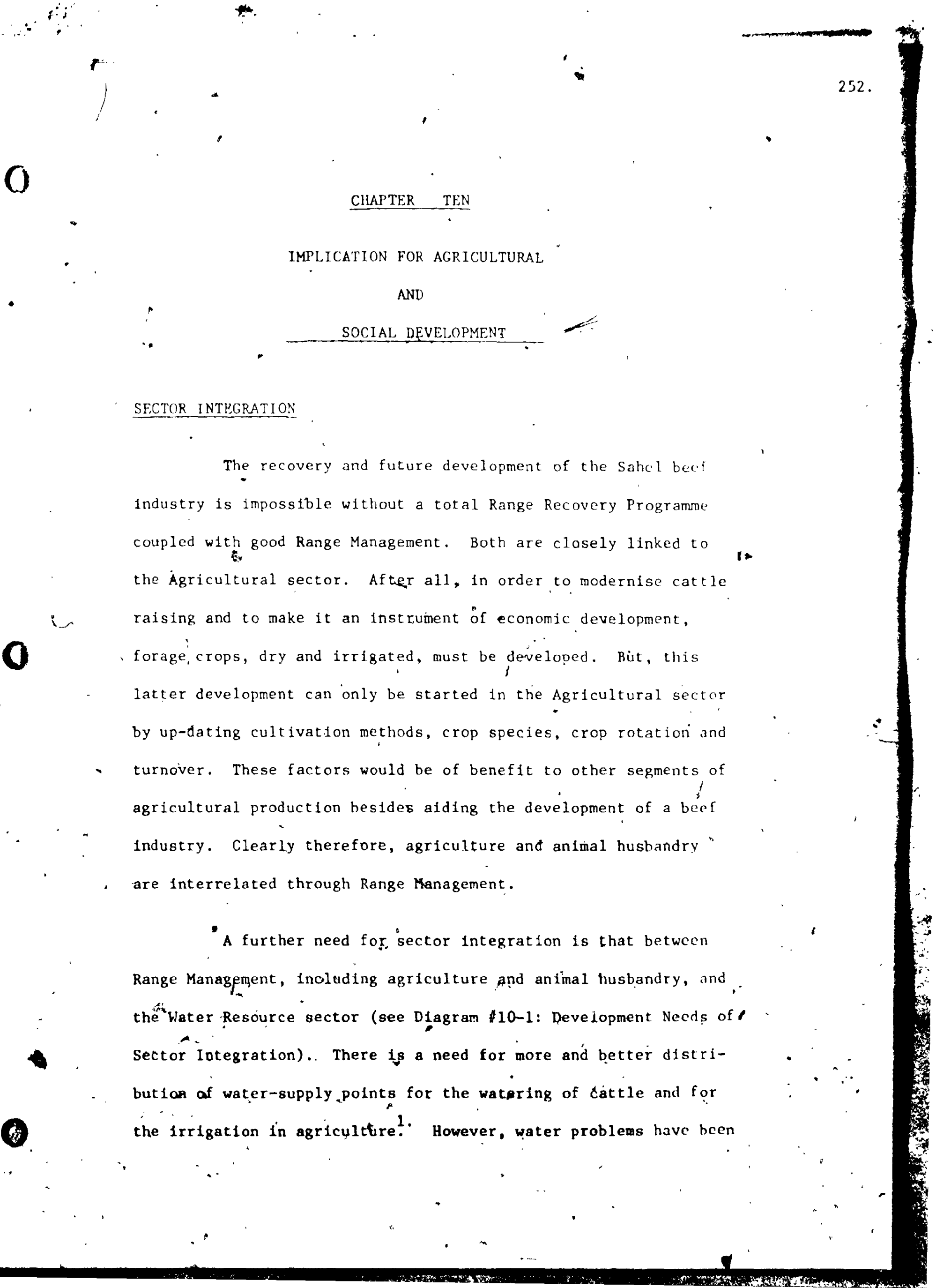



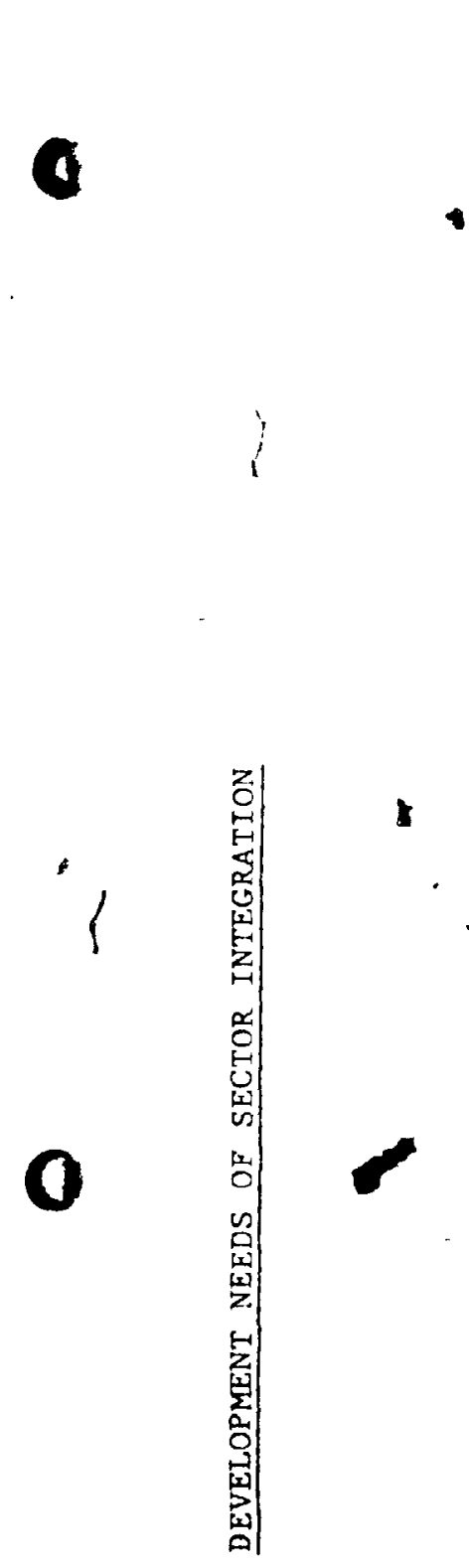

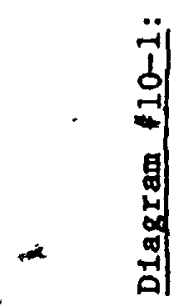

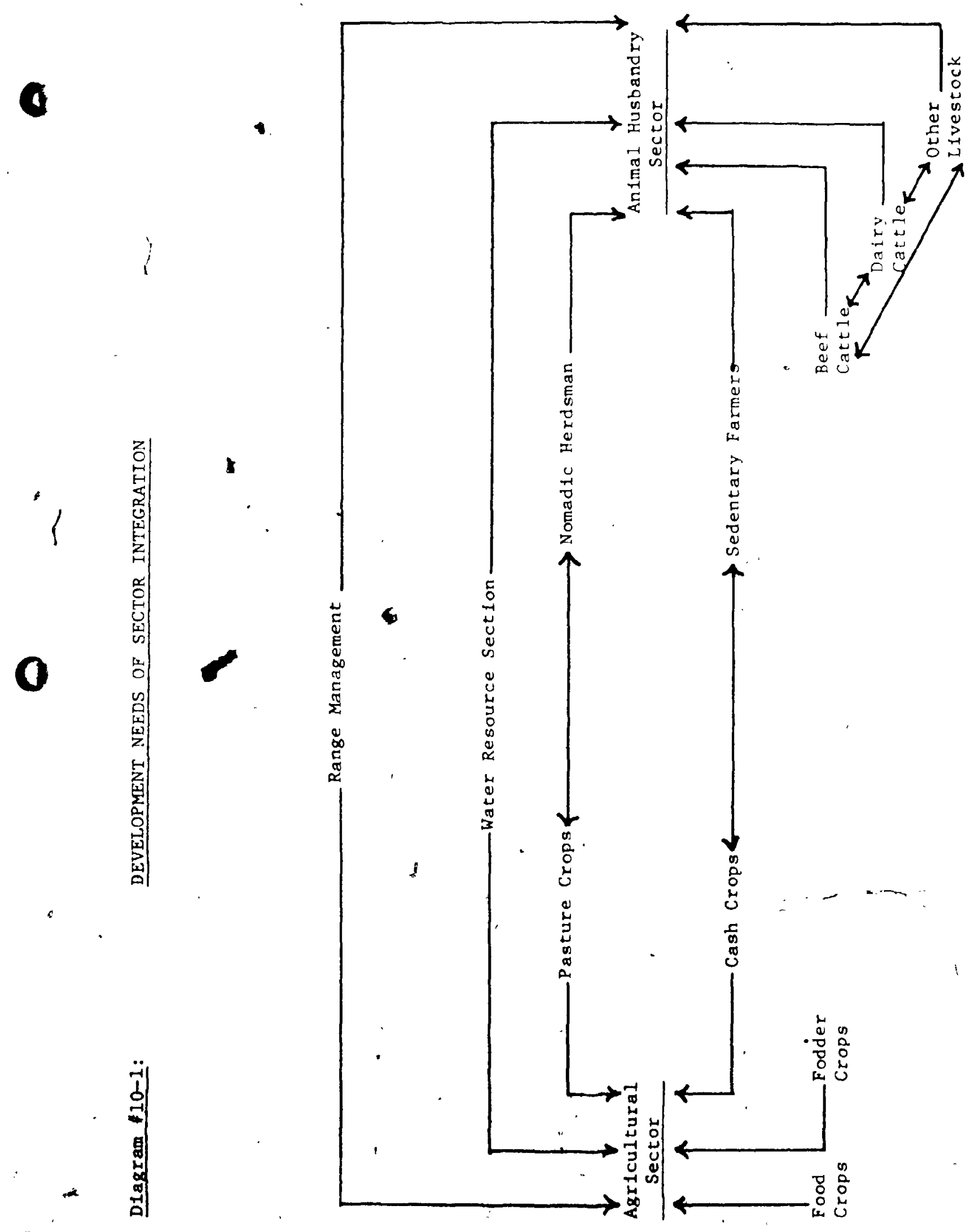

253. 
less acute for the cattle than for the agricultural needs of fodder crop production since the cattle die mainly from hunger (pastures were too dry for digestion). Thus, water-point establishment for Irrigated fodder production is posslbly more important for the Immediate future. Also, it is possible that there are presently enough water-points available for cattle, particularly in view of the

Sector integration can be more readily appreciated as a result of the practical application of the Beef Development Strategy set forth in chapters VIII and IX. Hence, it is now possible to consider some aspects of both Agricultural and Social Development.

\section{AGRICULTURAL DEVELOPMENT}

While there is already extensive agricultural development, mainly in the more. southerly wet areas of the Sahel, increased non-livestock agricultural planning can most assuredly complement the Beef Industry, in addition to providing economic benefits for the farmer.

Farmers must be encouraged to plant some of the new fodder crops (see chapter VII: Cattle Feeds) which are being developed, since these give high ylelds in semi-desert areas. In this context, the concern should be with the new hybrid varieties of the indigcnous 
crops such as maize, millet and sorghum. The harvested fodder could then be sold to provide additional income. In addition, part of the crop could be insillaged for dry-season feed to be used for the farmers own cattle; mainly draft and dairy animals at present. Such fodder crop production by the farmer could be In rotation with pastures on the arable soils of the agricultural areas, and also be in sufficient quantity to eventually support a year-round cattle feed-lot. Cattle operations established in the farming areas would be along the lines suggested in chapter VIII: Feed-lot Additions. However, the needs for agricultural production will be the size limiting factor for any southern area feed-lot operation, or Ranch.

There are many advantages to be gained by having feer-lots In the southern reglons of the Sahel, such as closer proximity to fodder feed supplements and to the domestic market. However, large Ranch operations to support the feed-lot may not be too practical since Ranches need room for expansion. Also, cattle are not usually the most economic product to be produced using good farm land, since there are many other agricultural products that must be grown which can not be grown in the more northerly regions.

However, the establishment of some sedentary farm area feed-lots can be justified because that would form a usefal part of the existing regional economic structure, namely, that of trading 
between the nomad and the farmer. The mfgratory herdsmen tradiLiunally need food grain and other crops to sustain their families. These can only be supplied by the sedentary farmer in exchange for cattle from the nomadic herds.

The location of additional cattle enterprises as part of the farm system would also allow the more effective use of the arable lands assoctated with all the farm regions. By this means, the present non-tillable land could be made to yleld a substantial income for the farmer, whlle at the same time, providing added employment in a region where people want to work but have few opportunities.

\section{SOCIAL DEVELOPMENT}

The success of any plan for development is very dependant upon the involvement and commitment of both the Governments and the people. Therefore, the beef strategy suggested involves the nomadic peoples in a most direct manner. Hence, there must be (a definite plan for soclal development whtch is closely linked to bdtt' the beef strategy and the agricultural plan. The reason for special social development is simply the fact that for any plan of"modernisation, the traditional lifestyle must undergo quite a subsfantial change. 
plan, but it will list the principal features of the 'traditional' soclety which will be changed through involvement in a modernised beef cattle industry.

1. Livestock are individually owned and they can be sold, with limits, by individuals acting independantly.

Under the Ranch coñcept of chapter VIII, all beef cattle will eventually be owned by the group of Ranch workers. This point was clearly indicated by Table \#9-1, chapter IX.

2. In contrast to the individual ownership of cattle, the tural resources necessary for cattle are not Individually owned. However, there is the opportunlstic exploitation of water and grazing, in the short-term, by groups.

Under the Ranch concept, the exploitation of water and grazing resources will no longer be opportunistic. The strategy of this paper showed that all resources would be carefully planned for both the short and long-term use.

3. 'Boundartes' are least flexible with large groups of people, but all are subject to seasonal change and demand pressures.

Under the Ranch strategy boundaries would no longer be flexible. Fences would serve as permanent nonflexible boundaries but the need for a seasonal change of pasture will be planned through the system of rotational grazing.- The question of demand pressures will be controlled through an increase in the take-off rate for slaughter.

4. Cattle are a multiple value item which cannot be equated in monetary terms. They represent power and prestige, which are pre-requisites for marriage and adulthood.

Under the Ranch strategy, through co-operative ownership and education, cattle would take on a very specific monetary value. In addition, it 1 s expected that the cattle would eventually lose their social importance, though it may take more than one generation. 
5. The cash incentive to market livestock is fairly low, "but then so is consumer demand in Africa. (3) This 1s, in part, a reflection of the dominant position of cattle in the scheme of values.

Under the Ranch strategy, through education, the cash incentive to market cattle is expected to increase.

6. The herd structure of the traditional nomad cattle herd is at variance with that needed for commercial beef production:

a) The value of cattle for social exchange purposes, encourages the keeping of old and weak animals.

Under the strategy proposed, the old and weak animals would be culled from the herd in keeping with good commercial herd development practices.

b) Cattle are generally required to meet the needs of subsistance.

The strategy will change this fact. Cattle will no longer be sold or traded for subsistance purposes. Instead, the cattle will become the most important piece in an economic mosaic.

c) A tradition herd will carry more mature males, than would be acceptable in a commercial herd.

The strategy stressed the separation of male animals before maturity. They would go directly to the feed-lot after being weaned so that they could be marketed as soon as possible at an acceptable slaughter weight.

d) The nomadic pastural economy consists of many animals, tended by, and supporting many people.

In the Ranch economy, such as in the more advanced countries, few people tend many cattle. The strategy systested a continuation of 'many cattle being 't \&nded by many people', though the quality of the herds-will be considerably Improved. 
7. There is a traditional hostility between many of the nomadic groups which, while sometimes practical in a hostile environment, could serfously jeopardize the development of Cooperative Ranches in the Sahel.

The strategy relies on the work and understanding of the Ranch Community Manager plus the success of the Ranch education program in order to eventually eliminate inter-group hostilities.

Clearly, for intensified animal protein production in the Sahel, whether the strategy of this paper is used, or some other plan, drastic changes in the way of life of the indigenous population is mandatory; particularly, a change from a situation whereby wealth is measured by stock numbers, to one gauged by monetary returns. Such a social transformation has only been undertaken in China, nowhere else in the Norld and could, therefore pose problems far more difficult to solve than those associated with the technical aspects of developing a successful beef industry.

However, the specific details of the soctal development needs will have to be documented separately by the sociologists, who would have to be active members of the Planning Organisation to be proposed in the next chapter. 


\section{FOOTNOTES}

1. This need is substantiated by the Report submitted by the Permanent Inter-State Committee on Drought Control in the Sahel. Submitted $25 / \mathrm{Jan} / 1974$ to the Special Sahelian office of the Untted Nations, New York.

2. The Masai of East Africa are a prime example of a case where the people were not comitted to the process of modernisation.

3. Indicative World Plan for Agricultural Development to 1975 and 1985 , Vol. I. 'Published by the FAO, Rome, 2968 p. $249 \mathrm{ff}$.
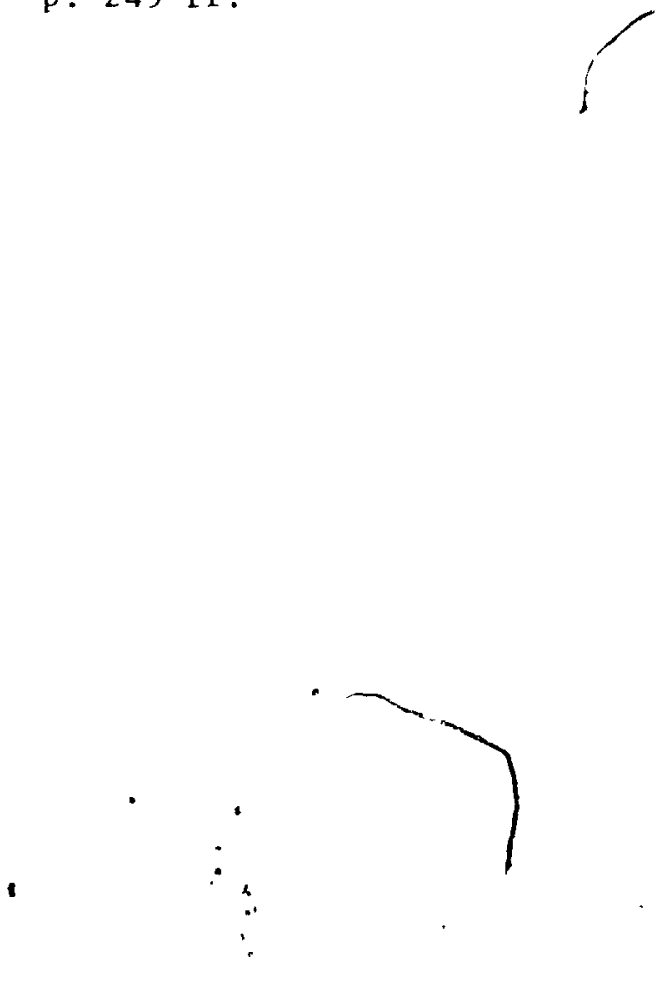
$\therefore$ 


\author{
CHAPTER ELFVEN \\ PROPOSED NEW ORGANISATION \\ FOR \\ STRATEGY IMPLEMFNTATION
}

While external aid, both in moncy, personnel and material

1s vital for the recovery and development of a heef cattle industry, these ingredients of aid are not adequate by themselves to ensure success. In theory it may be an easy matter to provide huge amounts of ald, but without local commitmgnt and involvement, any scheme would be doomed to fallure before it could even gegin. In the past, many development ideas have been started in a number of developing countries, but when aid flows ran dry, or were reduced the profect died. This has even happened in the field of beef cattle development in Africa when the early Kenya experiment is considered. The first kenya project for beef cattle ran for ten years, from 1953 to 1963, but instead of developing a viable and self-sustaining beefindustry, at the end of the project period the entire scheme disintegrated. The Kenya project was aimed at the semi-nomadic pasturalists of the arid and semi-arid areas with the idea of developing a more rational use of rangeland through regulated grazing and stock control. The Kenya scheme may he considered to have been technically successful, but the fdeas falled because they were pot fully understood: and supported by the Masai herdsmen, the very people the scheme was designed to help. 
It may be posstble to develop a beef industry in the Sahel without many of the nomadic herdsmen being involved. However, it must be remembered that all the economic development schemes must be for the benefit of the people in the respective countries. 'In addition, thé external aid donor nations cannot be expected to continue pourtng assistance into a country's programme of development if $i t$ is on project for which assistance would have to be continued 'ad infinitum'. Thus, any profect must contain the aim of eventual self-sustainment. To this end, there must also be local population involvement and commitment. This latter point can best be brought about by having the support of the National Governmerny in essence therefore, it might be said that the key to any success must be Government agreement.

In the Sahel countries, thys comitment will be hard to obtain if all six nations attempt to develop their own beef industry in isolation, without the co-operation of their neighhours. At this time a number of projects for livestock development are under conslderation by both the Governments of the Sahel countries and the external financial agencies. However, the thrust and objectives of these profects vary conslderably and are even contradictory in some instances (see discussion of chapter I).

In order to have a significant impact on the economies of the Individual Sahel nations, chapter VIII, set forth the out line 
of a total regional strategy for beef which vould cncompass all six Sahel countries. It should be noted that the beef strategy is just one of the sectors which can benefit from the total regional approach. To ensure the significant impact on the region and to ensure commitment and full cooperation of both the covernments and the people of the Sahel, including the coordination of the aid agencles, the following new Regiunal organisation is seen as the first step:

"Organisation for Range Management of" the Sahelian Countrifs." :

The new organisation must not.be too large or cumbersome, desntte the name. But, it must have the authority to act and make decisions on behalf of the indivimal Governments. 'Ithout such 'authority to act' it cannot be considered'as being 'responsible' for anything, and thus, it would rapidly deterforate into just another bureaucratic organisation.

The broad aims of the new organisation would be as follows:

1. To reclaim and/or develop all the pastureland available to the countries of the region.

2. To propose and Implement a long-term regional strategy to develop and stabilise the 11vestock industries for the social and economic beneftt of the nomads and the individual. nations.

3. To provide a solldly based 1ivestock industries organlsation which will withstand the recurring drought. 
0
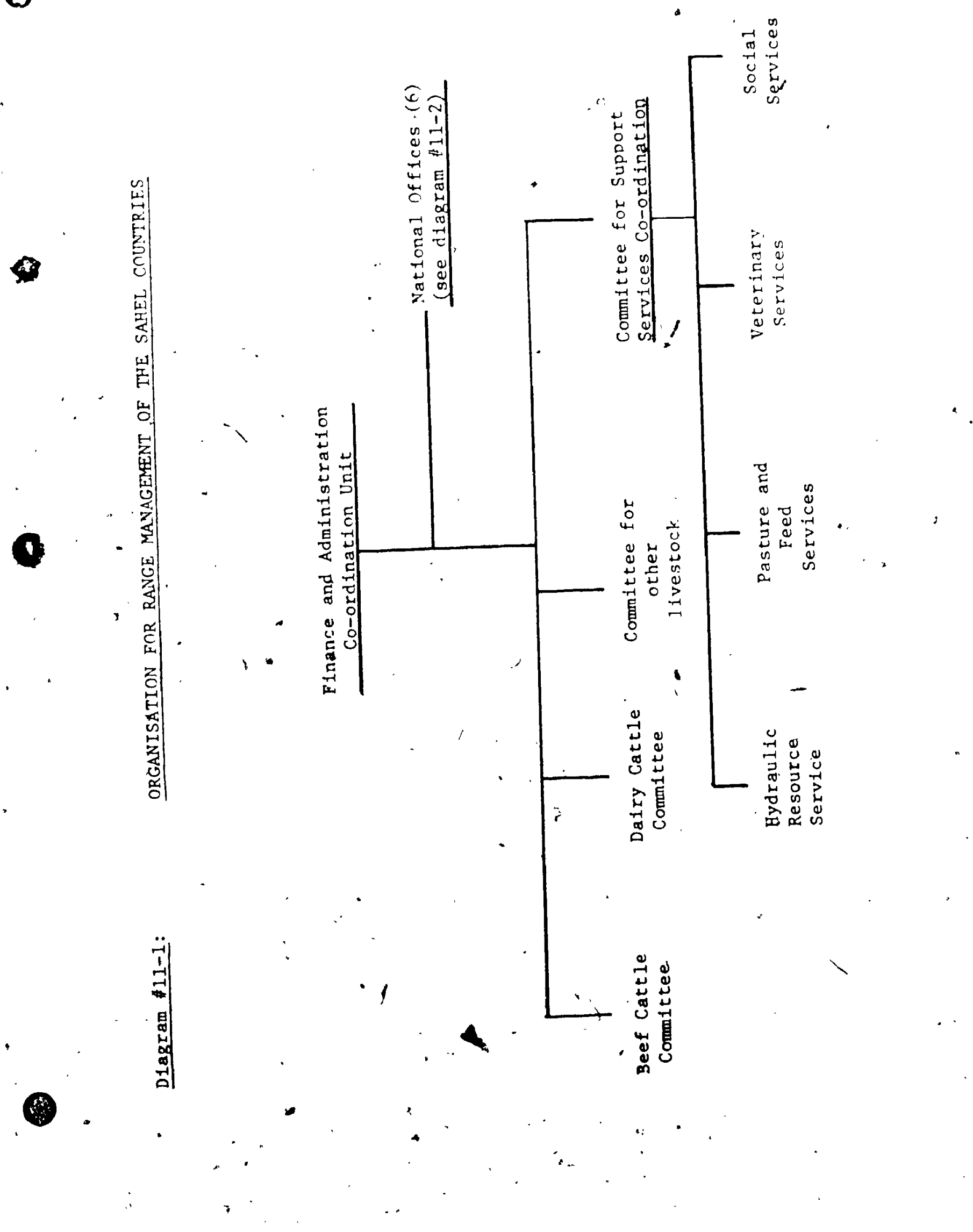
region could be carefully planned and comordinated for all three livestock sectors. A period of two years should be adequate for the preparation, co-ordination and funding of a fully integrated development scheme. Such an integrated scheme must plan on the development of a self-sustaining beef industry within a period of about fifteen years (the strategy of chapter viII shows that this would not seem an unreasonable target).

Once a self-sustaining beef industry has been established, in confunction with a similar objective for the other Comittees, this new organisation would be rendered ohsolete and thus could be disbanded. However, at that point in time it could be replaced by a Regional Corporation. The C.8rporation would then assume total responsibility for the profitable commercial operation of a Degional Livestock Industry reporting only to a Conimftee of the National Governments .

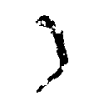

Beef Cattle Committee is the obvious way to ensure the cooperation of the ald donor agencies and the Governments of the aid receiving countries, such a Committee must also be active in the 'field', close to where the action is taking place. To this end, it is propased that this Regional Organisation would have six National Offices; one in each of the Sahel countries. The National offices would be composed of a number of Speclalists working in a closeknit team organised as show on diagram "11-2. 
0

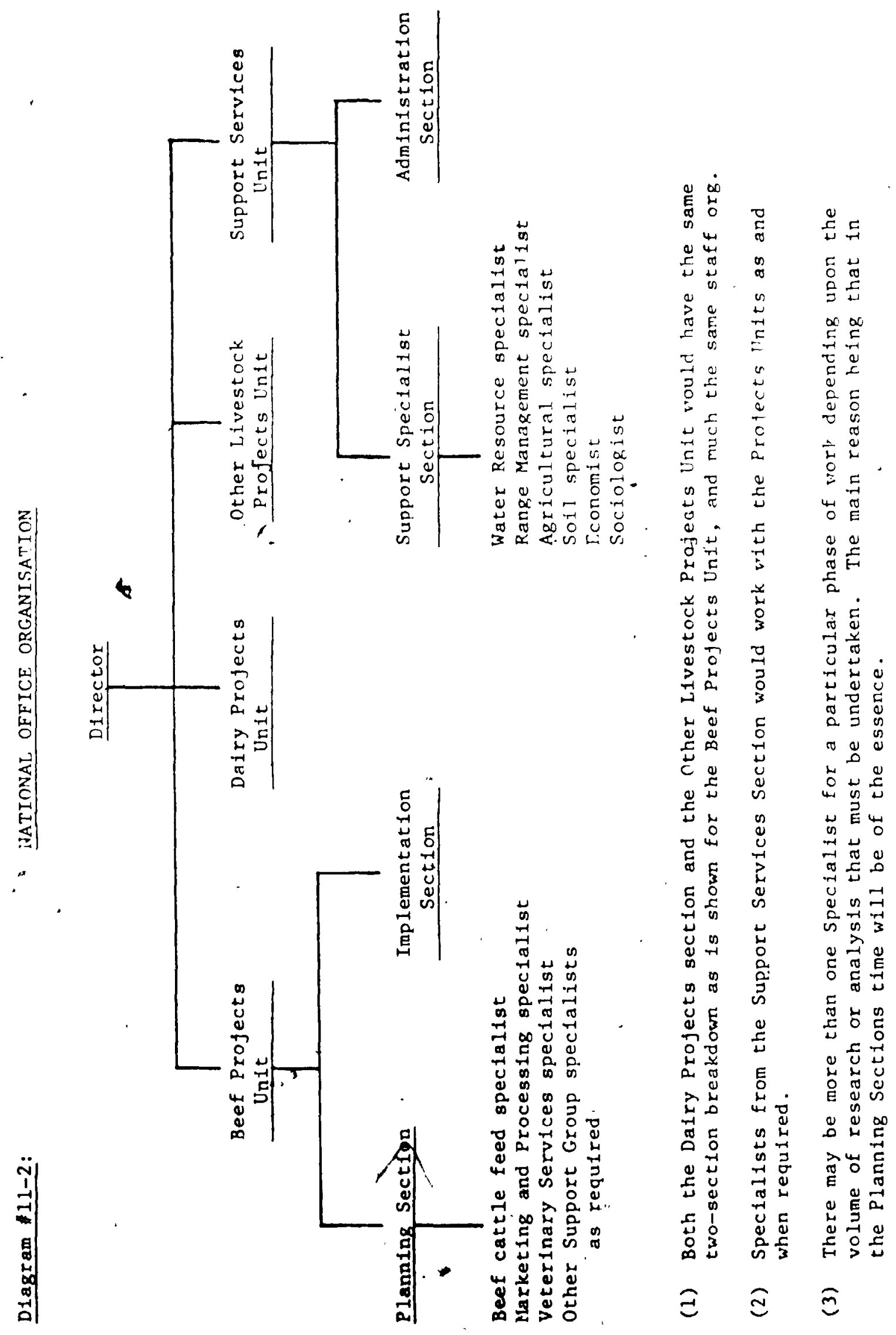




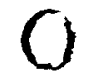

The Planning Section of each unit would be responsible for the primary analysis of the specific conditions as they apply to the individual country. From their analysis, in consultation with the other National offices, it would be possible to formulate a Regional Plan which would also list the feasihility calculations for the projects as they dertain to each country. Hopefully, such a Regional plan could he completely developed in 18-24 months, hence, the earlier suggestion in this chapter that, "Ideally, all the present plans for short-term livestock. development should be brought to a halt". At the end of 24 months, the new "Organisation for Range Management of the Sahel Countries" would be in a position to present a fully integrated pegional. Livestock Plan for all six Nations. With the inclusion of realistic cost and benefit'information, total agreement and commitment could be obtained from both the Governments and the aid donor agencies.

Once the Plan has been fully endorsed, the Implementation Sections of each lational office would be formed to assume complete responibility for the Plan's successful implementation. The personnel for both the Planning Section and the Implementation Section should be Sahel nationals as far as is posstble. Nonetheless, qualifications and ability must not be sacrificed to achieve this desirable increased African involvément in the Planning Section. However, it is very probable that the Implement- 
ation Sections will have a higher percentage of well-trained Africans than would the Planning Sections. This.would be a beneficial fact for the nations involved since these same people could readily be sorbed into the profit-raking Regional livestock Corporation.

As was the case with the Strategy of chapter VIII, which was purely theoretical until some facts and figures vere included in chapter IX. So with the new Regional Organisation for Range Management. Thus, Table \#11-1; details the approximate operating costs of both the Organisation Feadquarters $(\$ 805,000$ per annum for five years) and the six National offices $(\$ 937,000$ per annum per country for two years). These costs must be considered as Planning costs and should not be charged to the development of the three livestock sectors so covered.

This cost of the new organisation is over $\$ 15$ million, which may appear to be high. However, this is not a high price to pay if the overall long-term benefits of such a hody is considered. Funding for" all livéstock profects would be coordinated thereby reducing waste. The coordination and rationalisation of all research would be of great beneftt, because qualified people. for research and development within the contiment of Africa are st111 a scárce commodity. 


\section{HEADQUARTERS}

Director

Assistant Director; 2 secretaries; 2 Aides

Beef Cattle Comittee:

Chief; 2 assistants; 2 secretaries

Dairy Cattle Comittee: (as for Beef committee above)

Other Livestock Committee (as for Reef committee ahove)

Support Services Committee:

\begin{tabular}{ll} 
Hydraulic Resource Team & 60,000 \\
Pasture and Feed Team & 60,000 \\
Veterinary Service Team & 60,000 \\
Social Service Team & 60,000 \\
Miscellaneous costs & $-\quad 50,000$ \\
\hline
\end{tabular}

Office equipment, vehicles, travel and misc.

$$
\begin{array}{ll}
\text { Pasture and Feed Team } & 60,000 \\
\text { Veterinary Service Team } & 60,000 \\
\text { Social Service Team } & 60,000 \\
\text { Miscellaneous costs } & \quad \underline{50,0 n 0}
\end{array}
$$$$
\text { Support Services Conmittee: }
$$

U.S. nollars

$$
50,000
$$

65,000

100,000

1no, nno

100,000

$$
2 a n, 000
$$$$
\text { J.nก, non }
$$

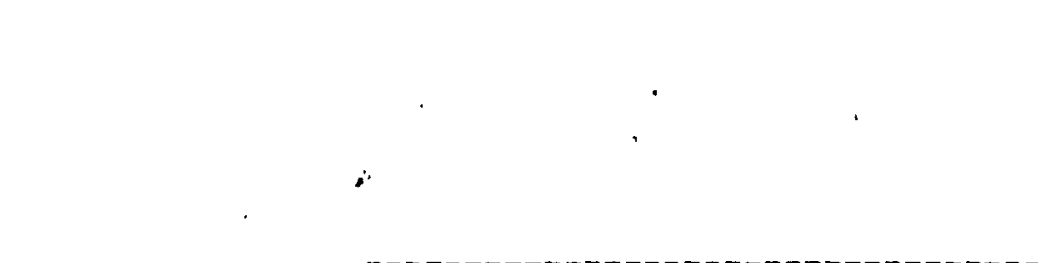

\section{1}

\section{NATIONAL OFFICES}

Director

Chiefs: $4 \times 35,000$

Specialists:. $16 \times 30,000$

Administration Section: Chief and Assistant

Secretaries and Miscellaneous personnel.

office equipment, vehicles, travel and misc.

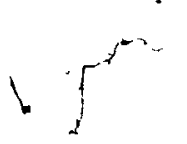

48,000

140,000

480,000

50,000

72,000

150,000

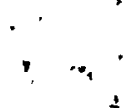

937,000

Source: Developed by the author 


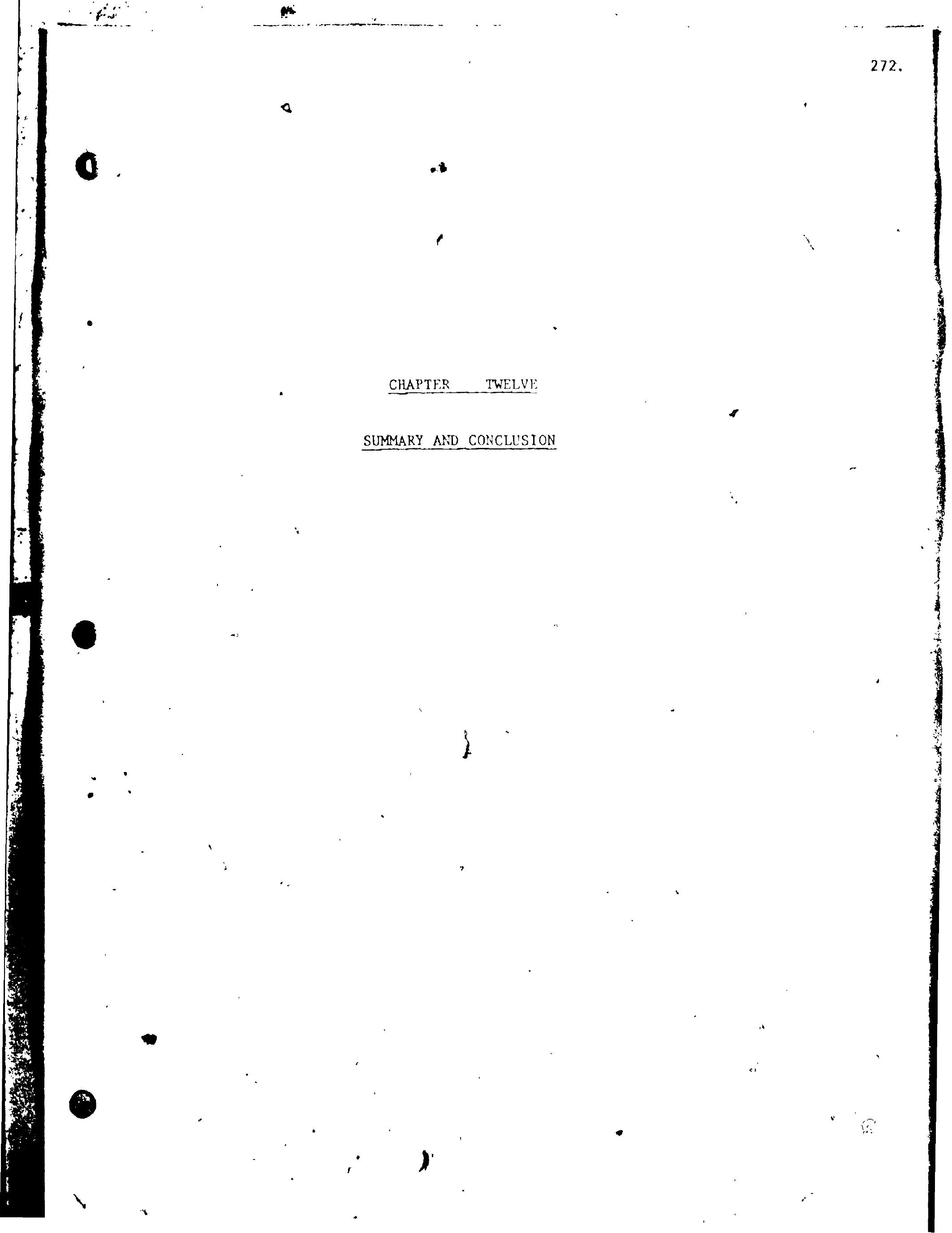




\section{CHAPTER TWELVE}

\section{SUIOIARY AND CONCLUSION}

The Thesis presented herein, dealt with two ideas which were shown to be very closely related. First, the Multi-national Ranch systen was proposed as a method for developing a substantial beef cattle Industry, the benefits of which could accrue, in some degree, to all the countries of the Sahel. The second idea concerned the retention of some of the nomadic traditions, though $x t$ is hoped that theix traditional value system (cattle as a sign of wealth) could gradually be changed.

Clearly, the easier of the two ideas to consider was that of the Ranch system as shown in chapter VIII. This aspect of the Plan really lies in the development of a technically feastble method which would enable cattle to improve according to the alms set down "The Aims of the Beef Cattle Development Strategy" (see chapter VIII). In the technical realm of the Plan fully Integrated Ranch operation was detalled to include the research suggested from chapter VII. The Ranch Plan included the full spectrum of the items which must be examined for the successful implementation of a self-sustaining beef cattle enterprise. Such 1tems as:-

1. Ranch Site Selection

2. Development of grazing sectfons - fencing, grazing; stocking-rate, water, forage, production, forage management and fodder production. 
3. The Herd - composition, breeding, calving, mortality and slaughter.

4. The Feedlot Operation - location, construction, stock capacity, water, feed types and feed balance.

5. The Abattoir Operatton - location, operation, markets and benefits.

6. Transportation Modes - Road, air and other morles of transportation.

7. Disease control.

8. Employment of Nomads

9. Long-term possibilities - additional Ranches, Ranch expansion and feedlot additions.

In line with the details of the Plan, certain economic linkages were mentioned, and many financial aspects were calculated for the pufposes of illustration. However, on this latter point, it should be emphasised that the tables of financial data were developed with as much accuracy as is possible short of being in the Sahel.

When dealing with the second idea, the 'nomadic traditions', while many of the nomadic attitudes were viewed as having to change (see chapter $X$ ), some vital traditional factors were to be retained.

- Primarily, of course, the idea of permitting the nomads to continue

dang what they know best, 'caring for catcle'. However, another vital tradition was also retalned, their value syster and the 'ownership of cattlel. But, while the method of implementing the plan of chapter VIII was stated in chapter IX, it will have been roted that. it did include the gradual introduction of the nomadic workcrs to a different value system, that of money. In addition, while introducting 
a monetary idea, considerable stress was placed upon the opportunity and the eventual benefts of some form of education. It was further intended in chapter IX, that the fact of an education and the working together could do much to reduce and eventually eliminate the traditional tribal hostilities. Only through education, monetary ideas and the disappearance of tribal hostilities will the question concerning, the operation and the subsequent Ranch ownership be transformed to a co-operative system.

In summary it may be said that this document was divided into three clearly defined sections. The first part, consisting of chapters II through VI inclusive, dealt with the problems, both past and present, of the countries which compose the area known as the Sahel. The second part, consisting solely of chapter VII, was concerned with a review of the research literature which could prove helpful in the Sahel.

Having defined the problems and reviewed the research, It was then possible, in the third section, chapters ViII to XI inclusive, to present some aims and objectives for a Reef Cattle Development Plan. Once these alms were specified, an involved Plan for Beef Cattle Development was presented in chapter VIII, with chapter IX being concerned with the actual detailed steps for successful Plan implementation. However, while the development and 
The expected results were seen as being the employment of 42,000 famllies $(250,000$ people) directly in the Ranches, with a minimum of $1.2 \mathrm{millt}$ on head of beef cattle being slunghtered for market anmually by the twentieth year.

Concerning the inputs, the total investment for the Ranch system covering the entire Sahel cattle region would he of the order of $\$ 96.5 \mathrm{million}$. There would be a further amount of $\$ 48$ million in repayable loans. While these two amounts may seem high if one considers that only about 250,000 people can be shown to be obtaining a direct benefit. However, as was pointed out in chapter VIII, there are many Economic Linkages which would lead to many more thousands benefitting indirectly. Unfortunately, this latter group cannot be estimated as yet.

In addition, the establishment of a second generation of Ranches will not be nearly so costly as the first six, since the stock and expertise will be readlly avallable from within the Nations of the Sahel. Besides which, thé then established Ranches will probably be generating enough funds (see Table \#9-2, chapter IX). to provide the necessary captal to finance a second generation of Ranches through the work and co-operation of the Inter-State Regional Livestock Corporation (see chapter XI).

To conclude, though all the alms and ohfectives of the Plan have been taken care of in the implementation method, it must 
be stressed that 'time and pattence' are really the main ingredjents for success, and that at no time must thesu two factors bo ignored. It is beter to delay the co-operat ive move and permit the nomads to keep some private cattle, than to rush the profit-sharing filea. Fallure to carefully consider the nomadic families at every point could leave each Ranch vacant with no workers,

$\therefore \quad$ 'Just another monument to another

Development Plan which did not work as anticipated'.

0 $\mid$
1

4

0 . 


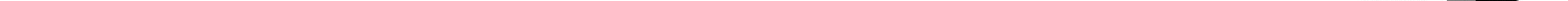


$x_{0} \quad \infty_{n}$
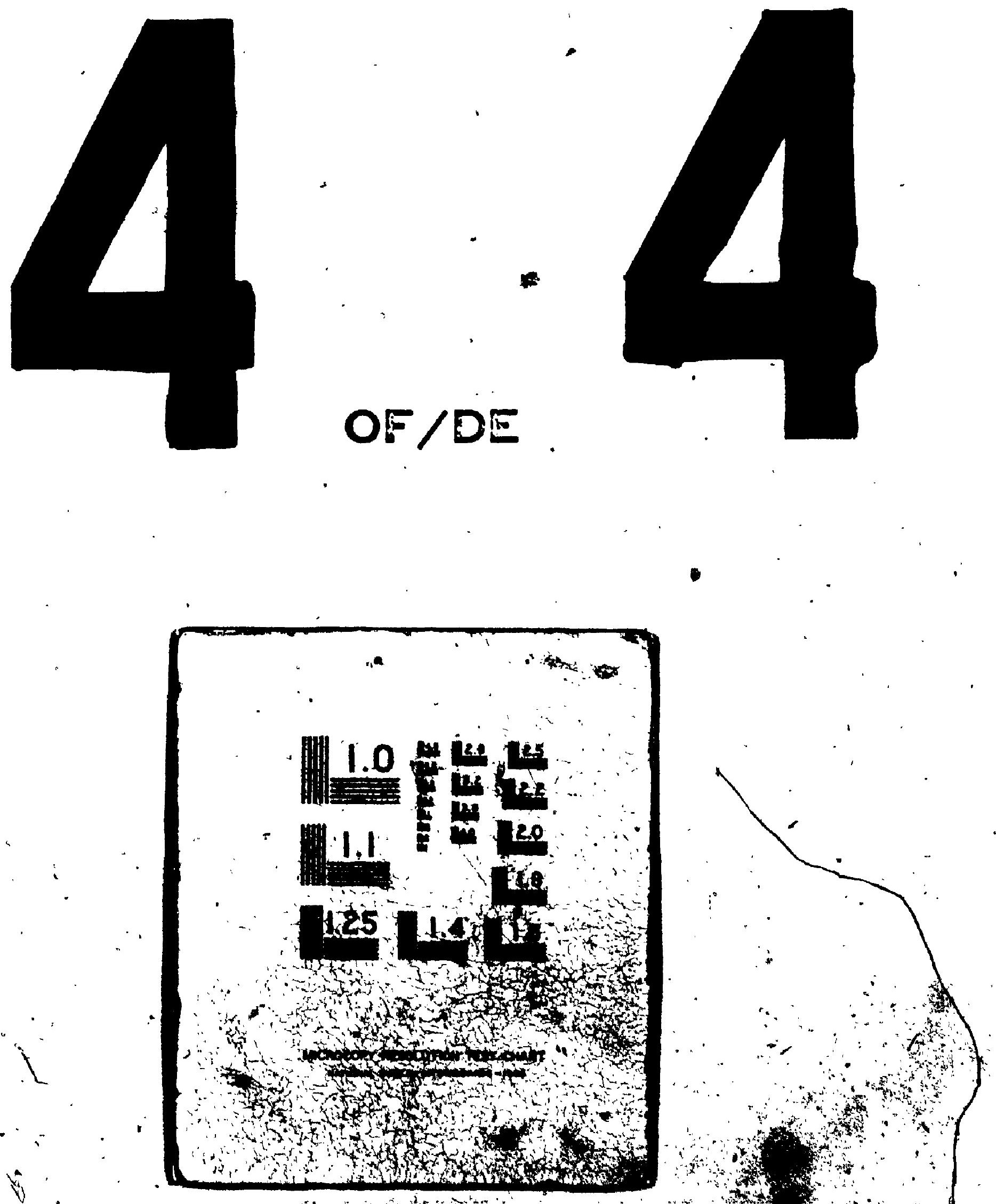
$x x^{\prime} \quad-\infty_{\infty}$
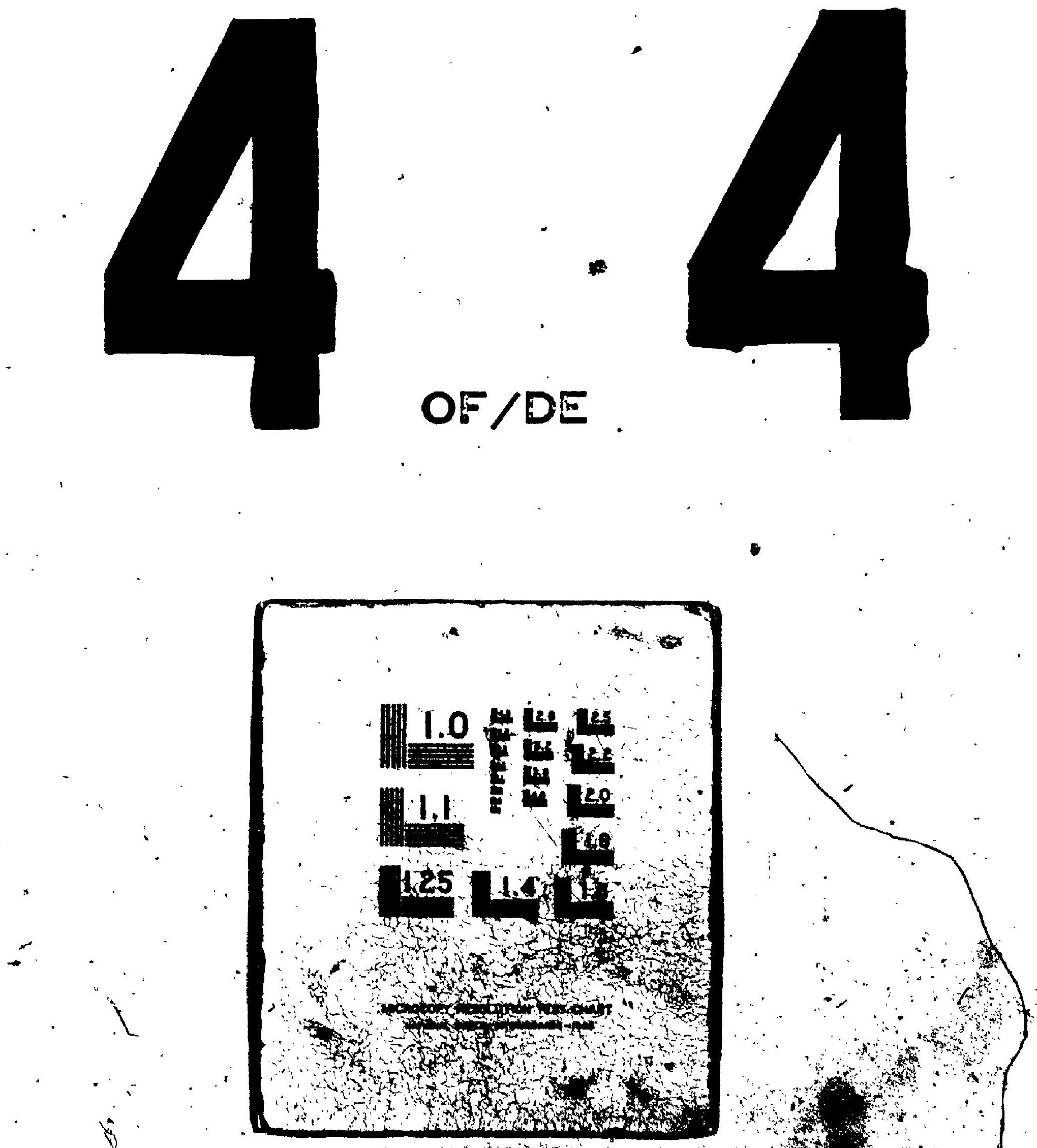
al 1 
$x+\infty$

.

Howells, w.

ILO

IMF

Jain, S.C.

Jensen, R. and

MacKay, D.C.

Johnson, H.G.
Kendren, W.G.

Back of History (Revised 3rd Edition), Doubleday and Co. Inc., New York, 1963.

Labour Force Projections - AfI1ca, Gerieva, 1971

Surveys of African Economies, ( 3 volumes), Washington, 1968, 1969, 1970.

Agricultural Development of African Nations, (2. volumes), Vora \& Co. Publishers, Ltd., Bombay, $1965 \& 1967$.

Diseases of Feedlot Cattle, Leu \& Febiger,

Philadelphia, 1971

Economf c Nationalism in 01d and New States, University of Chlaggo, 1967.

The Climates of the Continents, Clarendon Press, Oxford, 1961 .

MacEachern, G.A. The Economics of Beef, Agricultural and Economic

Research Counc1l of Canada, Ottawa, 1973.

Making, S.M.

Agricultural Problems of Developing Countries in Africa, Oxford University Press, Lusaka, 1967.

Marbut, C.F. and

Shantz, H.L.

The Vegetation and Sol1s of Africa, (1971 Reprint), AMS Press, N.Y. 1923.

Mason, I.L.

The Classification of West African Livestock, Conmonwealth Agricultural Bureau, Slough, Bucks, 1951.

McDonnel1

Improvement of Livestock Production in Warm Climates, W.H. Freeman and Co., San Francisco, 1972.

McLoughlin, P.F.M. Agriculture in East and Central Africa - An Overview, Kenya Litho Ltd., Nairob1, 1970.

M11f ord, R. and Tropical Pastures, Faber and Faber, London, 1966.

Minson, D.J.

Morris, R. and, Sheet $8, H$.

Disaster in the Desért - Failures of International Relief in the West Af rican Drought, Humanitarian Pollcy Studiea, The Carnegie Endownent for International Peace, Washington, 1974.

Mosher, A.T.

Creating a Bagressive Rukal Structure, Agricultural Development Counc11 Inc., New York, 1969. 
Payne, W.J.A. Cattle Production in the Troplcs, Vol. 1 - Breeds and Breeding, Western Printing Services Ltd., Bristol, 1970.

Persson, S, and Cattle Production in Africa, College of Agriculture, Sjobberg, K.E. Sweden, March 1974.

Phillips, J. Agriculture and Ecology in Africa, Faber and Faber, London, 1959.

Philips, J. The Development of Agriculture and Forestry in the Tropics - Patterns, Problems and Promises, London, 1961

Rouse, J.E. I World Cattle, University of Oklahoma Press, 1970

Sautr, C.0. - Agricultural Origins and Dispersals, Bowman Memorial Lectures, American Geographic Society, 1952. also 2nd Edition by M.I.T. Press, Boston, 1969.

Stenning, D.J. Savannah Nomads, Oxford University Press, London, 1964.

Topps, J. Animal Feeds of the Federation, University College of Rhodesia, 1961

Toynbee, A.J. A Study of History, Oxford University Press, London, 1947."

Trewartha, G.L. The Earth's Problem Climates, University of Wisconsin Press, Mapison, 1961

Wilde, J.C. de Experience with Agricultural Development in Tropical

WMO A Survey of Studies in Meteorology and Hydrology in The Sudano-Sahelian Zone of West Africas Gedeva, 1974.

Yorgason, V.W. Canada's Livestock - Meat System, Agricu1tural and Economic Research Councll of Cànada, Ottawa, 1973. 
REPORTS

AFRICAIRE

A Water Resource Development/We1l Construction Program in the Sahel. Washington, June 1074 .

CILSS

Report of the Permanent Inter-state Committee on Drought Control, Ouagadougou Conference, Sept. 1973. Report published Jan. 1974. (123 project proposals).

ECOSOC

Consideration of the Economic and Social Situation in the Sudano-Sahelian Region Strickened by Drought and Measures to be taken for the Benefit of that Region. Report of the Secretary-General to the 57 th Session of ECOSOC, June 1974.

ECOSOC

FAO

The International Development Strategy: First overall Review and Appraisal of Issues and Policles. Preliminary Report of the Secretary-General to Comitte for Development Planning, 9th Session, 2/13th Apr11, 1973. Published March 1973.

Esst Afr1ca Livéstock, Rome, I967

FAO

FAO and WHO

Meat Hyglene and Abatto1r Management, Kenya, 1966.

FAO

Report of the 3rd FAO Meeting on Livestock Production in the Americas, Rome, 1955.

FAO

Report of the 6th Regional Confefence for Africa, Alger1a, 19 sept. - 3 Oct. 1970.

Report of the 7th Regional Conference for Africa, Gabon, $14 / 30$ sept. 1972 .

Etude sur la situation actuélle de l'Elevage dans les pays du Sahel et des mesures de sauvegarde a enviagger. Rapport par Ponds Européen de Développement pour le Commission des Communautées Europeennes. february, 1974.

IBAH 13th Annua 1. Report, 1964, of the Inter-African Bureau of Gimal Health.

Dynanic of Livestock Production in Sub-Saharan Afrtca, Sept. 1970. Report by J.F. Franson, R.H. Khourl and R. Milford. 



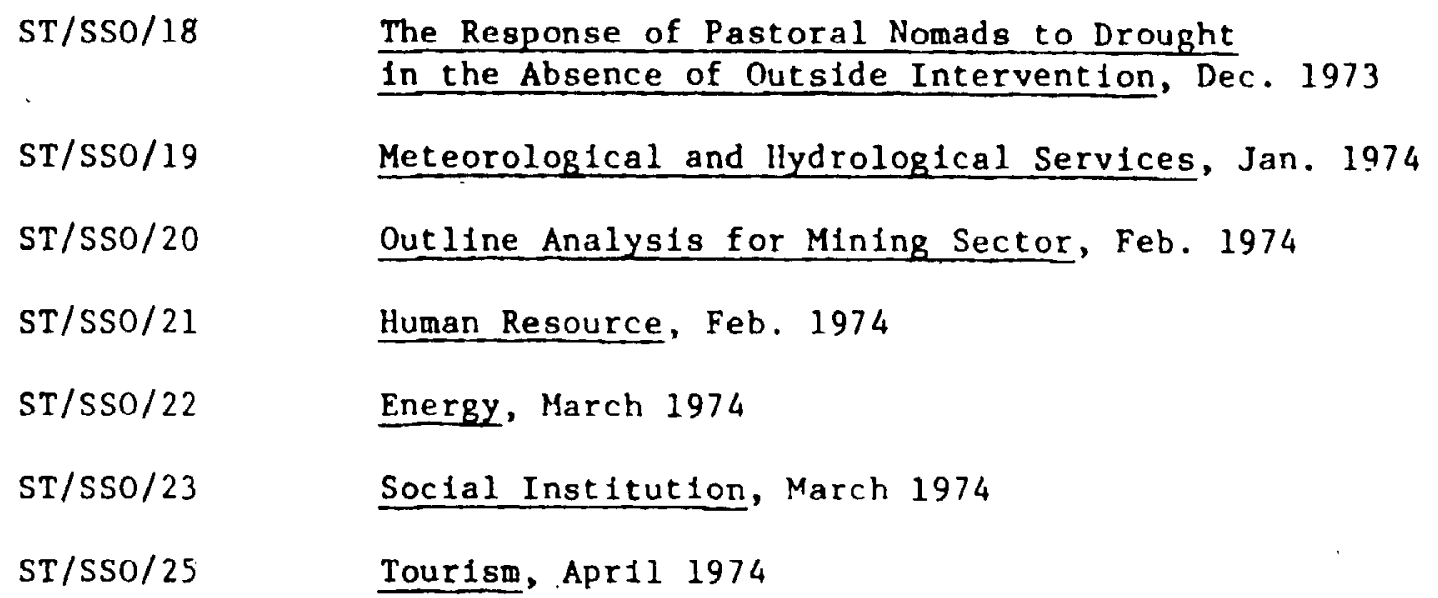

\section{PAPERS}

AERCC

A Review of Agricultural Policy in Canada, Ott awa, 1966.

Brumby, P.J. International Financing for Livestock Development, 21/Sept./1972

Brumby, P.J. Some Economic Aspects of Tropical Pasture Improvement

FAO Prospects for Production, Marketing and Trade in Livestock and Livestock Production in East Africa to 1985 .

IBRD

Proposal for a Co-operative Effort to Rationalize the Livestock Industries of the Sahel. Presented at the Sahel Conference, New York, August 1974.

Mbliny1 Agricultural Research Problems in East Africa, $j$ University of Dar Es Salaam, Sept. 1972.

Pino, J.A.

Discussion Paper on Livestock Production in Tropical Africa, for the Bellagio IV Conference, 1970.

Rockefeller F. Strategies for Agricultural Education in Developing Countrles. Conference discussion paper nct. 1974 reported in Dec. 1974. 
S.E.D.E.S.

3

Sprague, H.D.

Schaefer, M.

Supply1ng Middle-West Afrlca with Meat, "

Paper presented to Société d'Etudes pour le

développenent economique et social, Paris, 1969

r.

A comprehensive system for recovery and reconstruction of apriculture in the six drought strickened West African countries, 1974

sso

Conserving fodder and bullding-up fodder reserves, Paper presented at the 2nd Meeting of the FAO working paper on Mediterranean Pasture and Foddex Development, 1953.

Consideration of the situation in the SudanoSahelian Region strickened by drought and the medium and long-term measures to be taken for the benefit of that region, June 1974 .

sso

An approach to recovery and rehabilitation of the Sudano-Sahelian Region, 1974.

Taxas Tech. U. Ranching/Mixed Agriculture Programme in Niger, presented at the Sahel Conference, New York, Aug: 1974 printed in Lubbeck, June 1974.

UNDP

-DP/GC/NER/R.1

Country \& Intercountry Programming $\mathrm{DP} / \mathrm{GC} / \mathrm{CHD} / \mathrm{R} .1$ $\mathrm{DP} / \mathrm{GC} / \mathrm{MLI} / \mathrm{R} .1$ $\mathrm{DP} / \mathrm{GC} / \mathrm{UPV} / \mathrm{R} .1$ $\mathrm{DP} / \mathrm{GC} / \mathrm{SEN} / \mathrm{R} .1$

Niger 1972-76

1973-76

$29 /$ Nov/1973

Chad

1974-76

1/Dec/1971

Mal1

1972-76 29/0ct/1973

Upper Volta

$1974-76$

$30 / \mathrm{Mar} / 1973$

Senegal

$1 /$ Sep/1973

Environment Agency

Cattle Feedlot and the Environment, presented at the U.S. Environment Protection Agency, Washington, April 1972 


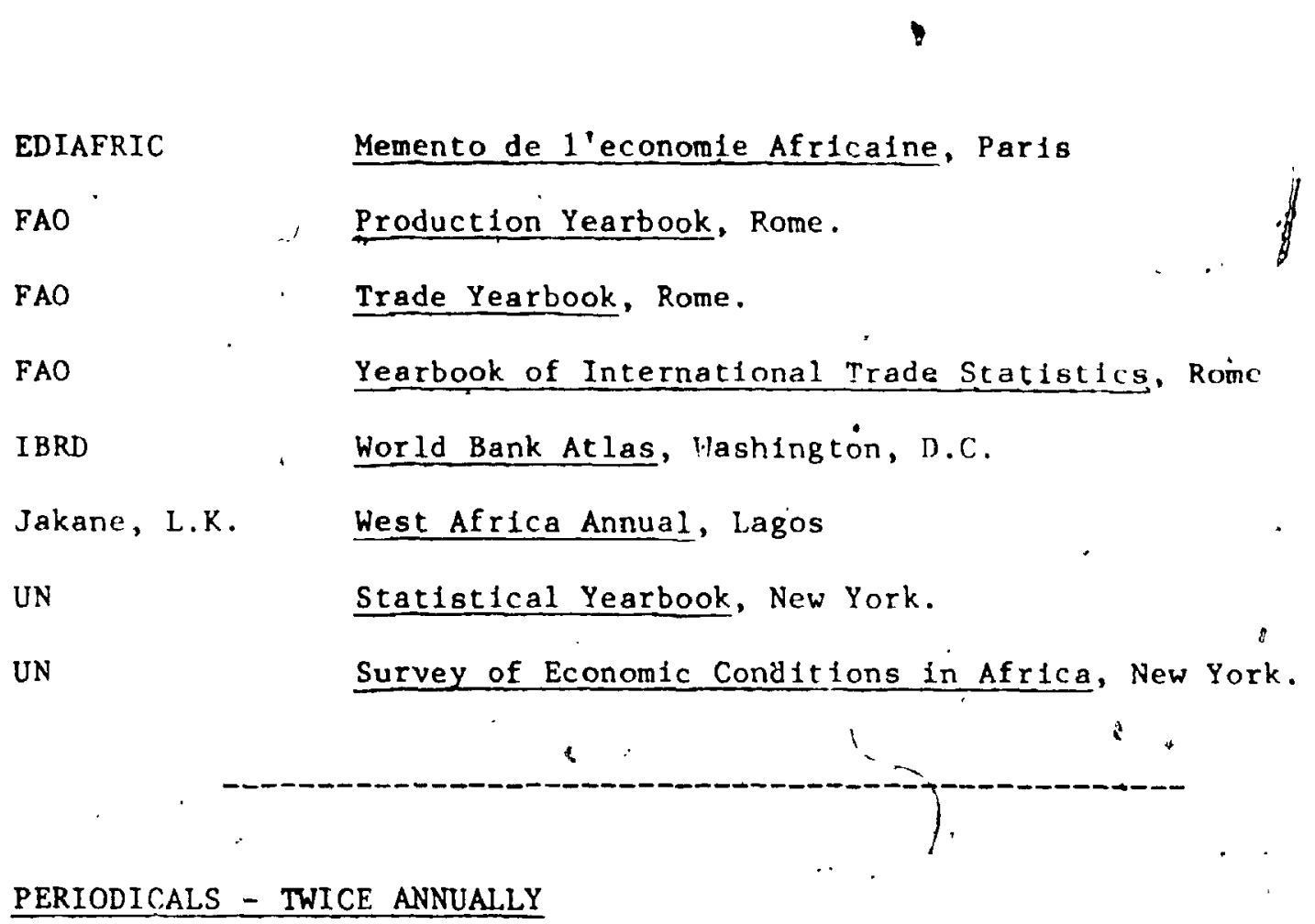

African Social Research, Zambla

FAO/ECA Agricultural Economic Bulletin for Africa, Addis Ababa.

PERIODICALS - QUARTERLY

AID

Development Digest, Washington, D.C.

CJAS. Canadian Journal of African Studies, Montreal.

Rhodesian Dept: Rhodesian Ágiculcure Journal, Salisbury. of Agric.

FÁO

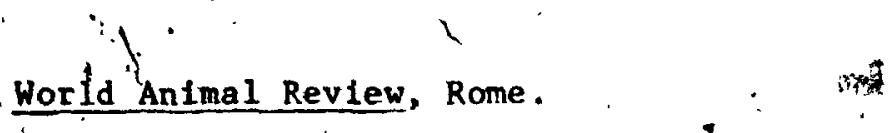

IBED

Bulletin of Ep1zootic Diseases of Africa. 
Australian Journal of Experimental Agrtculture and Animal Husbandry.

\section{PERIODICALS - BI-MONTHLY AND WEEKLY}

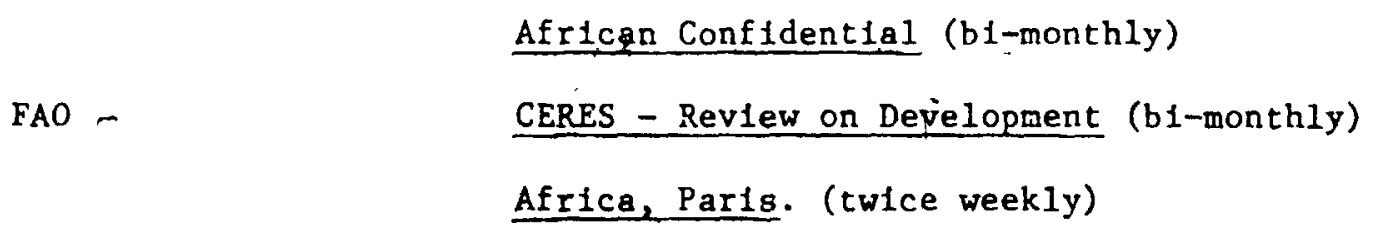

Daily

Christian Science Monitor

Citizen

Globe and Ma11

New York Times

Washington Post

Press Releases

Food and Agriculture Organisation

United Nations

World Food Programme 


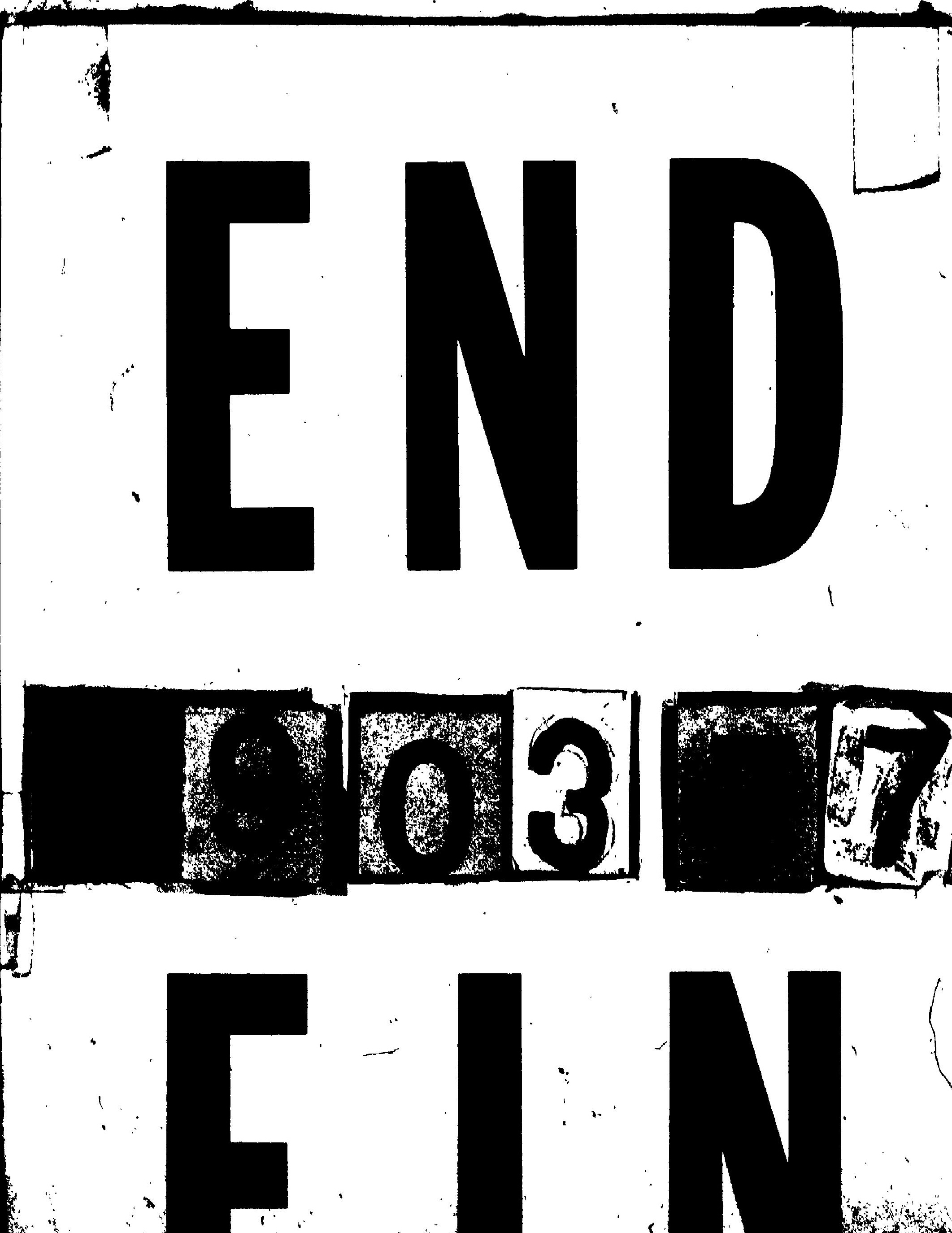

